
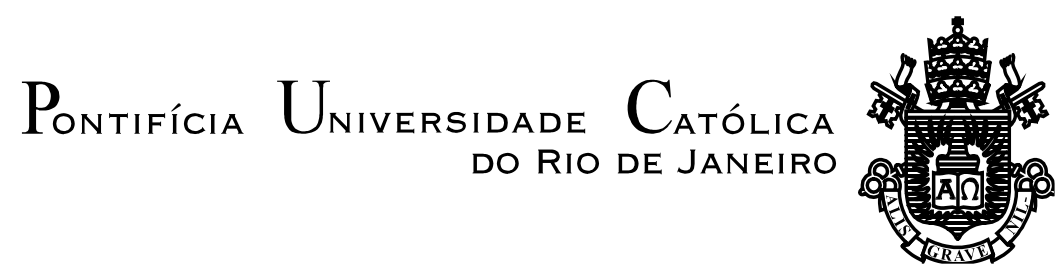

Luis Felipe de Azevedo Araujo

\title{
O Biogás de Aterro e seu Aproveitament Energético nos Caminhões de Coleta de Resíduos Sólidos Urbanos
}

\section{Dissertação de Mestrado}

Dissertação apresentada ao Programa de Pós-Graduação em Engenharia Urbana e Ambiental da PUC-Rio como requisito parcial para obtenção do título de Mestre em Engenharia Urbana e Ambiental (opção profissional).

Orientador: Prof. Tácio Mauro Pereira de Campos

Rio de Janeiro

Novembro de 2014 

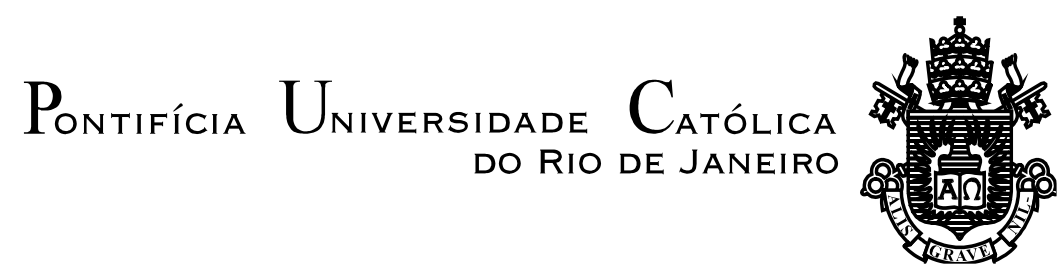

Luis Felipe de Azevedo Araujo

\title{
O Biogás de Aterro e seu Aproveitamento Energético nos Caminhões de Coleta de Resíduos Sólidos Urbanos
}

Dissertação apresentada como requisito parcial para obtenção do título de Mestre pelo Programa de PósGraduação em Engenharia Civil da PUC-Rio. Aprovada pela Comissão Examinadora abaixo assinada.

\author{
Prof. Tácio Mauro Pereira de Campos \\ Presidente/Orientador \\ Departamento de Engenharia Civil - PUC-Rio
}

Profa. Ana Cristina Malheiros Gonçalves de Carvalho PUC-Rio

Prof. Alcir de Faro Orlando

PUC-Rio

Prof. Leonardo Augusto Lobato Bello UNAMA

Prof. José Eugenio Leal Coordenador Setorial de Pós-Graduação do Centro Técnico Científico - PUC-Rio

Rio de Janeiro, 21 de novembro de 2014 
Todos os direitos reservados. É proibida a reprodução total ou parcial do trabalho sem autorização da universidade, do autor e do orientador.

\section{Luis Felipe de Azevedo Araujo}

Arquiteto e urbanista. Graduado na Universidade Santa Úrsula, Rio de Janeiro, 1988. Participou da exposição Arquiteto do Amanhã, (IAB), representando a Universidade Santa Úrsula, 1988. Estagiou e trabalhou em vários escritórios de Arquitetura. Cláudio Bernardes e Jacobsen associados, Índio da Costa arquitetura, Zanine Caldas e na Petrobrás. Atualmente trabalha com construção e reforma de interiores. Ingressou no mestrado de Engenharia Urbana e Ambiental em 2010. Principais áreas de interesse: Novas Tecnologias ambientais, Planejamento Urbano, Reciclagem, Resíduos Sólidos Urbanos.

Ficha Catalográfica

Araujo, Luis Felipe de Azevedo

O biogás de aterro e seu aproveitamento energético nos caminhões de coleta de resíduos sólidos urbanos / Luis Felipe de Azevedo Araujo; orientador: Tácio Mauro Pereira de Campos. - 2014.

208 f. : il. (color.) ; $30 \mathrm{~cm}$

Dissertação (mestrado) - Pontifícia Universidade Católica do Rio de Janeiro, Departamento de Engenharia Civil, Programa de Pós-Graduação em Engenharia Urbana e Ambiental, 2014.

Inclui bibliografia

1. Engenharia civil - Teses. 2. Biogás. 3. Resíduos sólidos urbanos. 4. Energia. 5. Caminhões de coleta de resíduos. I. Campos, Tácio Mauro Pereira de. II. Pontifícia Universidade Católica do Rio de Janeiro. Departamento de Engenharia Civil. III. Título. 


\section{Agradecimentos}

À Paula Enoy, que esteve sempre disposta a me ajudar, e também pela sua simpatia e amizade por todos esses anos.

Ao Professor Alcir de Faro Orlando, pela ajuda prestada durante a parametrização dos resultados, sem o qual não seria possível a conclusão do trabalho.

Ao Professor Celso Romanel, que me ajudou na decisão de escolher o tema desta dissertação.

Ao Professor Tácio Mauro Pereira de Campos pela orientação, incentivo e presteza no auxílio às atividades $\mathrm{e}$ discussões sobre $\mathrm{o}$ andamento $\mathrm{e}$ desenvolvimento desta dissertação. 


\section{Resumo}

Araujo, Luis Felipe de Azevedo; de Campos,Tácio Mauro Pereira (Orientador). O Biogás de Aterro e seu Aproveitamento Energético nos Caminhões de Coleta de Resíduos Sólidos Urbanos. Rio de Janeiro, 2014, 208p. Dissertação de Mestrado - Departamento de Engenharia Civil, Pontifícia Universidade Católica do Rio de Janeiro.

Nos grandes centros urbanos, o aumento da geração de Resíduos Sólidos Urbanos (RSU) é bastante superior ao crescimento da população; milhares de toneladas de lixo são despejadas diariamente em lixões ou aterros sanitários, exigindo investimentos cada vez maiores. Um sistema de limpeza urbana poderá ser implantado a partir do abastecimento dos caminhões de coleta de resíduos sólidos com o biogás produzido pela decomposição da matéria orgânica contida nos RSU depositados nestes aterros. Fonte renovável de energia, ao contrário do carvão, petróleo ou gás natural, o biogás, assim utilizado, traz significativa redução na emissão de gases de efeito estufa (“GEE”) e benefícios ao meio ambiente e à saúde da população. Este trabalho busca avaliar em aterros onde existe uma ampla produção de biogás, a possibilidade da aplicação de uma porcentagem do que é gerado para suprir a demanda de combustível de uma frota de caminhões coletores compactadores, (que são os veículos que mais emitem $\mathrm{CO}_{2} / \mathrm{Km}$, além da intensa poluição sonora), substituindo o diesel mineral. São duas as tecnologias de aproveitamento do biogás a serem abordadas. A primeira refere-se ao aproveitamento do biogás para a geração de energia elétrica e sua utilização em caminhões elétricos e a segunda, em caminhões abastecidos com GNV (Gás Natural Veicular). Nesta perspectiva, os aterros deixam de ser apenas depósito final de resíduos; tornam-se um início de um novo ciclo de vida desses resíduos. Os sistemas de limpeza urbana serão projetados por analogia aos ecosistemas biológicos, criando um conceito original de ecossistema do lixo.

\section{Palavras-chave}

RSU; Biogás; Aterro sanitário; Caminhão de coleta de resíduos; Ecosistema do lixo. 


\section{Extended Abstract}

Araujo, Luis Felipe de Azevedo; de Campos, Tácio, Mauro Pereira (Advisor). The Landfill Biogas and its Energetic Use in MSW Collection Trucks. Rio de Janeiro, 2014, 208p. MSc Dissertation Departamento de Engenharia Civil, Pontifícia Universidade Católica do Rio de Janeiro.

The production of MSW (Municipal Solid Waste) is inevitable and occurs daily. Their amount varies depending on the level of economic development and the different layers that society entails. Managing information of MSW's lifecycle, from collection, treatment, disposal, recycling and energy recovery, becomes increasingly important to build a solid foundation for sustainable development.

In the definition of United Nations Environment Programme (UNEP), sustainable consumption means the supply of services and related products that meet basic human needs and promote their best quality of life not only current, as future generations. Therefore, sustainable consumption matters in particular attention for the use of natural resources and toxic substances as well as on strict control of waste and pollutants emissions during the life cycle of the product or service. In a scenario of climate change, with the growing consumption of disposable things and energy and also consequent increase of garbage production, adoption of more sustainable lifestyles must be an obligation, compatible with lower rates of utilization of natural resources and levels emissions of greenhouse gases (GEE). More than any other time, mankind finds itself in a crossroad. Since Industrial Revolution, in a traditional economic vision, technology and the market think that they will always be able to find replacements for finished natural resources and solutions to environmental degradation. Mankind requires energy to perform most of their daily activities. This energy comes from primary sources such as oil, coal, gas (non-renewable), or another nature, as occurs with biomass, solar and hydropower and biogas (renewable). The future development depends on availability of energy for a long time in increasing amounts secure, reliable sources and appropriate to environment.

In primitive societies, when main activity was hunt and pick fruit from trees, waste was biodegradable. Garbage production began to increase with 
emergence of cities and with population growth. Large human groups began to settle in certain areas, no longer behaving exactly in terms of its growth, moving from one place to another. Since then, accumulation of residues has become a huge problem.

Over the years, the trenching to bury waste seemed enough to resolve the inconvenient appearance of insects and rodents near the locations where it was deposited the garbage.

The expansion of cities, large population agglomerations, changes of habits and industrial development (more disposable packaging and other inert materials), aggravate the problem of final disposal of MSW. The fact that waste cease to have economic value after the disposal does not make them disappear. Collect all and give them a proper disposal becomes a huge challenge for Governments, scientists, industry and the general population.

Inadequate sanitation of cities is still today one of the main causes of diseases, in addition to significant economic losses. Efficiency waste management is an essential condition for the improvement of environmental quality.

In large centers, waste generation growth is significantly higher than that of the population; thousands of tons of garbage are dumped daily into landfills or in places that doesn't have any type of preparation to receive these MSW, requiring larger investments, to recovery that areas.

Among the possibilities of MSW final destination, landfills are the largely form used for treatment still in Brazil and in several countries around world, especially those who have big territorial extension, because of its lower operating costs and great waste absorption capacity, when compared to other forms of final destination (or treatment), such as incineration and composting.

Most of the materials found in the urban waste is actually a combination of several substances from different points of the planet and, theoretically, can and should be recycled. In Brazil, however, is virtually a impossible task. Technical and economic factors hinder much of recycling process, leaving as an alternative disposal in landfill. Packaging and collection methods used in almost cities mix these materials, making it difficult separate by screening processes currently used. As a result, both composting plants, as techniques of selective collection of waste end up producing materials that necessarily should be despised. Even incinerators, 
which, in theory, reduce waste of 5 to $15 \%$ of original volume of waste, generate slags and ashes that end up deposited in landfills.

Despite of these facts, selective collection has to be stimulated through vigorous public campaigns, gives priority to recycling and greatly reduces the amount of waste being sent to landfills. It is necessary, therefore, that it will be increasingly adopted by Brazilian cities, since, they have logistics planning for collection and it does not contribute to worsen even more the saturated traffic of big cities.

The MSW deposited in landfills contains significant portion of organic matter; by the action of micro-organisms is its degradation, turning it into a gas known as biogas. In most Brazilian landfills, the organic matter is more than $50 \%$ and the biogas generated, has, as a basic feature, a concentration above $30 \%$ of $\mathrm{CO}_{2}$ (Carbon Dioxide) and 50-55\% of $\mathrm{CH}_{4}$ (Methane), approximately. The latter's gas could be captured and harnessed as a source of renewable energy, by virtue of its high calorific value. Developed countries are already applying technologies for energy use of MSW with different purposes, including generating electricity, direct use in industry and as a fuel for vehicles NGV (Natural Gas Vehicles). The use of biogas integrates a MSW management system.

In a country like Brazil, where the monumental production of MSW cause huge social and environmental impacts, the inclusion of biogas in its energy matrix is a promising alternative ( and also the country doesn't have enough energy to increase your development economic growth). The MSW directly affect environment in different ways as with air pollution (decomposition and collect), noise pollution (collect) and the soil (decomposition). A recent research appointed that garbage's transportation emits most $\mathrm{CO}_{2}$ per kilometer run in Brazil, than any other vehicle. According to a research done by a fleet management company, (ECOFROTAS, 2011) garbage collection trucks emit about 1,24 $\mathrm{Kg}$ of $\mathrm{CO}_{2} / \mathrm{Km}$ per run, because of its type of operation, (stop and go, in a slow march). In another hand, landfills, emit each year 7 million tons of methane $\left(\mathrm{CH}_{4}\right)$ that goes directly to the atmosphere, contributing even more to increase the greenhouse effect and the global warming.

It is true that cannot disregard the realities of third world countries. Not always the community has sufficient resources for implementation and operation of a proper waste treatment system. Brazil has very low rates of investment and 
consequently the incorrect form of disposal of waste, is observed in most municipalities.

Urban cleaning costs are divided between collecting, sweeping, treatment and final disposal of MSW. Many variables influence these costs, like the number of employees, wages, frequency, logistics, recycling and the quality of the services provided.

In many Brazilian cities, solid waste collection consumes a significant percentage of municipal budgets. Surpasses, in some cases, spending on public health services.

The main objective of this work is to study the possibility of fuel change in household/ public garbage collectors compactors trucks and make proposals to reduce the effects of emissions of polluting gases arising from the collection and the decomposition of municipal solid waste ("MSW") in landfills.

Source mineral diesel, fuel used in this type of vehicle, would be all replaced or in part, by biogas/NGV and/or electricity, produced by the landfill biogas.

There are two technologies of biogas utilization to be investigated. The first refers to the use of biogas for power electric generation and its use in electric trucks and the second, in trucks fueled by NGV.

According to a study from the World Bank (2004), the possibility economic of collecting and using biogas is normally limited to large and deep landfills (above 1 million ton waste and depth with more than $15 \mathrm{~m}$ ) and for cities with at least 400.00 habitants or that may can establish a relationship of sharing land with neighboring municipalities, so that they can possibility generate energy with gas from garbage.

The Jardim Gramacho landfill (RJ) despite is not receiving more waste since 2012, will serve as a model to test the possibility of its replication in other landfills of several Brazilian municipalities. With a daily production of approximately $480.000 \mathrm{~m}^{3}$ of biogas, the question is to know what would be the percentage (at least, less than $30 \%$ of the monthly generation) of their use as fuel to supply 296 trucks compactors collectors of Municipal Urban cleaning Company, RJ, (COMLURB), and how much (and if) would be used as energy to be injected into the supply network (electric or pipeline), saving costs with fuel 
(diesel) for at least, 10 years, creating new opportunities for its economic exploration.

A new urban cleaning system can be deployed to supply MSW collection trucks with biogas produced in landfills (or biodigestors, if the city has an efficient collect selective). From this point of view, landfills are no longer just the final destination of the MSW, it becomes a stage of a new life cycle of MSW. Urban cleaning systems could be designed by analogy as a biological ecosystems, a concept of waste ecosystem.

Meanwhile, the reduction of fossil fuel consumption is directly proportional to the emission of air pollutants as well as cost reduction, it can be affirmed that the practice proposed in this work can generate benefits at the environmental, social and economic scope.

Local environmental gain is observed through the air quality and by the reduction of morbidity and mortality issued air pollution in major urban centers. In a near future, most of collections, especially home/public,(because of saturation of the traffic), shall be carried out increasingly in night shifts, performed by electric and/or hybrid trucks NGV/ electric, which produces much less noise and $\mathrm{CO}_{2}$ than the regular ones (diesel). In other words, decreasing local concentration of air pollution and noise, improve life quality of the habitants of large cities.

In the case of emissions avoided by the new collection system, allows estimating a gain associated with carbon credits established by Kyoto Protocol, for example. A system that generates electricity from landfill biogas to fuel garbage collection trucks is yet, unprecedented in the world.

\section{Keywords}

Municipal solid waste (MSW); Environmental impacts; Biogas; Landfill; Garbage truck collection; GHG emissions. 


\section{Sumário}

1. INTRODUÇÃO 20

1.1. Consumo sustentável 20

1.2. Objetivo 22

2. RSU E O MEIO AMBIENTE 23

2.1. O lixo, um problema desde sempre 23

2.2. Destinação final adequada dos RSU (realidade brasileira) 26

2.3. Matéria orgânica dos RSU e o biogás 27

2.4. Poluição atmosférica 28

2.4.1. Poluição do ar associada aos transportes de RSU 28

2.4.2. O uso do (bio)diesel na coleta de RSU e a poluição emitida no Brasil

2.4.3. Desvantagens associadas ao biodiesel 32

2.5. Emissões de gases de efeito estufa 32

2.5.1. Potencial de aquecimento global e as emissões brasileiras 36

2.5.2. Estimativas de emissões de $\mathrm{CO}_{2}$ por veículos automotores 39

2.5.3. Emissões de outros gases de efeito estufa por queima de combustíveis

2.6. Poluição sonora e a coleta de RSU

2.7. Impacto ambiental $\quad 45$

2.7.1. Impactos ambientais de um aterro sem a preparação adequada 46

2.7.2. Emissões de GEE no município do Rio de Janeiro, RJ 47

2.7.3. Emissões de GEE dos diferentes tipos de resíduos 49

2.7.4. Impactos ambientais e o ciclo de vida de um caminhão pesado 50

2.7.5. Ciclo de vida dos caminhões no Brasil 53

3. A LIMPEZA URBANA: CLASSIFICAÇÂO, COLETA E TRANSPORTE DOS RSU

3.1. Classificação e características dos RSU

3.2. Características $\quad 64$

3.2.1. Características físicas $\quad 64$

3.2.2. Geração per capita $\quad 64$

3.2.3. Composição gravimétrica 66

3.2.4. Peso específico $\quad 67$

3.2.5. Teor de umidade $\quad 67$

$\begin{array}{ll}\text { 3.2.6. Compressividade } & 68\end{array}$

$\begin{array}{ll}\text { 3.3. Características químicas } & 68\end{array}$

3.3.1. Poder calorífico $\quad 68$

3.3.2. Potencial hidrogeniônico $(\mathrm{pH}) \quad 69$

3.3.3. Composição química $\quad 69$

3.3.4. Relação C:N ( Carbono/Nitrogênio) 69

3.4. Características biológicas $\quad 69$

3.5. Acondicionamento, coleta e transporte de RSU 71 
3.5.1. Acondicionamento de RSU

3.5.2. Acondicionamento de resíduo público 74

3.6. Custos da limpeza urbana $\quad 78$

$\begin{array}{ll}\text { 3.6.1. Custos da limpeza urbana no Brasil } & 78\end{array}$

3.6.2. Custos da limpeza urbana no mundo $\quad 80$

3.7. Coleta e transporte de RSU 83

3.7.1. Sistemas de coleta de RSU no mundo 102

4. TRATAMENTOS DOS RSU 112

4.1. Alternativas de tratamento dos resíduos 112

4.2. Reciclagem 113

4.3. Compostagem associada aos biodigestores 116

4.4. Incineração 118

4.5. Destinação final adequada dos RSU 120

4.5.1. Aterros sanitários: Definições e características 121

4.5.2. Aterros como biorreatores 131

5. ENERGIA RENOVÁVEL: O BIOGÁS DE ATERROS E SEU APROVEITAMENTO

5.1. Formação do biogás de aterro 133

5.2. Estimativas do potencial de geração de biogás no aterro 139

5.3. Gráfico da emissão de metano do aterro 150

5.4. Determinação do potencial energético do aterro 152

5.5. Meios de aproveitamento energético do biogás 153

$\begin{array}{ll}\text { 5.5.1. Produção do combustível para veículos } & 154\end{array}$

5.5.2. Produção de energia elétrica 163

5.5.3. Cogeração 166

5.5.4. A energia elétrica no uso em veículos 168

5.6. Viabilidade econômica do aproveitamento do biogás 169

5.7. Utilização do biogás de aterros no Brasil 176

6. O APROVEITAMENTO ENERGÉTICO DO BIOGÁS DO ATERRO DE JARDIM GRAMACHO NOS CAMINHÕES DE COLETA DE RSU NA CIDADE DO RIO DE JANEIRO

181

6.1. A capacidade de fornecimento do biogás em relação ao número de caminhões atendidos

6.2. Estimativas de produção de energia elétrica 182

6.3. Estimativas de produção do GNV 184

$\begin{array}{ll}\text { 6.4. Parametrização dos resultados } & 185\end{array}$

6.5. Aspectos econômicos e ambientais 186

$\begin{array}{lr}\text { CONCLUSÃO } & 194\end{array}$

REFERÊNCIAS BIBLIOGRÁFICAS 


\section{Lista de figuras}

Figura 1 - Evolução dos veículos de coleta de RSU. 24

Figura 2 - Proporção entre a população urbana e rural entre 1940/2000. 25

Figura 3 - Evolução da geração de RSU e evolução da população entre 2000 e 2010 no Brasil.

Figura 4 - Estimativa da produção de RSU no Brasil.

Figura 5 - Fórmula estrutural do metano.

Figura 6 - Esquema do efeito estufa.

Figura 7 - Série histórica de emissões de $\mathrm{CO}_{2}$ Brasil. 38

Figura 8 - Comparação internacional entre os maiores emissores.

Figura 9 - Esquematização da metodologia Top-down.

Figura 10 - Procedimentos adotados para estimar as emissões.

Figura 11 - Fontes de ruído veicular.

Figura 12 - Participação dos setores na emissão de GEE da cidade do Rio de Janeiro, em 2005 (Gg. $\mathrm{CO}_{2}$ eq.).

Figura 13 - Emissões de GEE no Setor de Resíduos ( $\mathrm{Gg} \mathrm{CO}_{2}$ eq.).

Figura 14 - Impactos ambientais do ciclo de vida de um caminhão pesado.

Figura 15 - Curva de sucateamento veículos no Brasil.

Figura 16 - Classificação para os resíduos sólidos.

Figura 17 - Calçada sem possibilidade de circulação.

Figura 18 - Relação per capita entre a produção domiciliar de resíduos e o número de habitantes.

Figura 19 - Caçamba Estacionária ou Caixa Dempster / Brooks.

Figura 20 - Custos per capita dos serviços de limpeza urbana nas cidades. 
Figura 21 - Comparação dos gastos per capita dos serviços de limpeza urbana nas cidades com a quantidade de resíduo per capita.

Figura 22 - Modelos de cestas coletoras de RSU para coleta seletiva (BRASIL).

Figura 23 - Municípios com coleta seletiva no Brasil. 88

Figura 24 - Caminhão de coleta seletiva, RJ. $\quad 88$

Figura 25 - Coleta seletiva Rio de Janeiro, RJ. 89

Figura 26 - Tipos de carrocerias compactadoras no Brasil. 96

Figura 27 - Caminhão poliguindaste duplo com contêineres intercambiáveis.

Figura 28 - Caminhão de coleta de RSU movido a biogás, Toronto, Canadá.

Figura 29 - Frota de caminhões movidos a GNV.

104

Figura 30 - Caminhão de coleta de RSU movido a GNV, Chesapeake, Virginia, EUA.

Figura 31 - Caminhão movido a gás / Porto Alegre, Brasil.

Figura 32 - Abastecimento caminhão híbrido com energia elétrica.

Figura 33 - Caminhão elétrico (França).

Figura 34 - Esquema de coleta pneumática de resíduo. Barcelona, Espanha.

Figura 35 - Gráfico comparativo entre Taxas de Reciclagem.

Figura 36 - Etapas metabólicas do processo de digestão anaeróbia em biodigestor.

Figura 37 - Fases do gerenciamento de resíduos sólidos do município.

Figura 38 - Esquema de um evaporador de chorume.

Figura 39 - Dreno típico de aterros, que pode ser adaptado e inserido no sistema de captação de biogás.

Figura 40 - Cabeçote de adaptação de dreno existente. Modelo utilizado na Europa e EUA. 
Figura 41 - Desenho esquemático de um sistema de captação de biogás de aterro sanitário.

Figura 42 - Sistema de captação do biogás e geração de energia elétrica em aterro sanitário.

Figura 43 - Flares de aterros sanitário.

Figura 44 - Fases da geração de biogás e do chorume.

Figura 45 - Curva de geração de metano, em função do tempo do aterro. Interpolação das metodologias da USEPA, B.M., e IPCC.

Figura 46 - Curva de geração de metano, em função do tempo do aterro. 151 Variação das taxas $\mathrm{K}_{0}$ e $\mathrm{L}_{0}$.

Figura 47 - Esquema de aproveitamento energético do biogás.

Figura 48 - Conceito de conversão de veículos pesados diesel/GNV.

Figura 49 - Conceito esquemático transformação do motor diesel para GNV.

Figura 50 - Conversão por adaptação motor original a diesel.

Figura 51 - Comparação da emissão de poluentes em veículos pesados movidos com diesel, gás natural comprimido (GNC) e com a combinação de ambos.

Figura 52 - Motor ciclo Otto adaptado a biogás.

Figura 53 - Desenho esquemático de uma microturbina a gás.

Figura 54 - Instalações com microturbinas em aterros.

Figura 55 - Estimativa do potencial de geração de energia a partir do biogás proveniente da disposição de RSU nos municípios do Brasil.

Figura 56 - Diagrama com as alternativas de aproveitamento do biogás.

Figura 57 - Vista aérea do aterro Jardim Gramacho/RJ.

Figura 58 - Diagrama com as alternativas dos modelos de exploração do biogás de aterro e suas diferentes opções de aplicação nos caminhões de coleta. 


\section{Lista de tabelas}

Tabela 1 - Principais Gases de Efeito Estufa, suas origens e potencial de aquecimento global.

Tabela 2 - Indicadores de emissão de $\mathrm{t} / \mathrm{CO}_{2}$.

Tabela 3 - Níveis de potência sonora.

Tabela 4 - Classificação dos resíduos de saúde.

Tabela 5 - Composição gravimétrica do lixo de alguns países (\%).

Tabela 6 - Componentes mais comuns da composição gravimétrica.

66

Tabela 7 - Fatores e influências na geração de resíduos.

Tabela 8 - Quantidade de resíduos encaminhados para disposição em solo, 78 considerando somente lixão, aterro controlado e aterro sanitário no Brasil.

Tabela 9 - Percentual do orçamento municipal destinado à limpeza urbana.

Tabela 10 - Resumo das principais informações entre cidades selecionadas.

Tabela 11 - Destino e quantidade diária de RSU, Rio de Janeiro, RJ.

Tabela 12 - Responsabilidade por tipo de resíduo.

Tabela 13 - Carrocerias sem compactação mais utilizadas no Brasil.

Tabela 14 - Tipos de estações de transferência.

Tabela 15 - Quantidade diária de resíduos sólidos domiciliares e/ou públicos encaminhados para diferentes formas de destinação final (2000 a 2008).

Tabela 16 - Tipos de aterros sanitários.

Tabela 17 - Composição biogás de aterro.

Tabela 18 - Tempo de decomposição do lixo.

Tabela 19 -Fases típicas de produção do biogás. 
Tabela 21 - Valores recomendados para o COD nos principais tipos de resíduos.

Tabela 22 - Incerteza associada aos parâmetros sugeridos pelo IPCC.

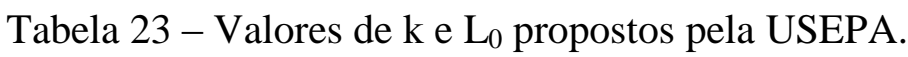

Tabela 24 - Estimação da densidade do lixo depositado.

Tabela 25 - Eficiência do sistema de controle (n cont.).

Tabela 26 - Códigos de qualidade dos fatores de emissão.

Tabela 27 - Valores para $\mathrm{k}$ propostos em correspondência com a precipitação anual.

Tabela 28 - Valores $\mathrm{L}_{0}$ em função da degradabilidade do resíduo.

Tabela 29 - Emissões de gases por veículos pesados.

Tabela 30 - Parâmetros de entrada da coleta COMLURB- Rio de Janeiro,

RJ.

Tabela 31 - Parâmetros de entrada para energia elétrica.

Tabela 32 - Aproveitamento do biogás como energia elétrica.

Tabela 33 - Aproveitamento do biogás com GNV em energia elétrica equivalente.

Tabela 34 - Comparação dos consumos equivalentes em 2 turnos de $8 \mathrm{~h}$.

Tabela 35 - Poluição emitida pelos diferentes modelos de veículos de 187 coleta.

Tabela 36 - Valores associados à produção e consumo do biogás.

Tabela 37 - Custos gerais de veículos. Instalações e rendimento médio dos 191 caminhões.

Tabela 38 - Valores economizados com a substituição do diesel. 


\section{Lista de símbolos}

Ag Prata

CFCs, Clorofluorcarbonetos

Cd Cádmio

$\mathrm{CH}_{3} \mathrm{COOH}$ Ácido acético $\mathrm{CH}_{4}$ Metano

CO Monóxido de Carbono

$\mathrm{CO}_{2}$ Dióxido de Carbono

Fe Ferro

$\mathrm{H}_{2}$ Hidrogênio

$\mathrm{H}_{2} \mathrm{~S}$ Gás sulfídrico

$\mathrm{HC}$ Hidrocarbonetos totais

HFCs, Hidrofluorocarbonetos

Hg Mercúrio

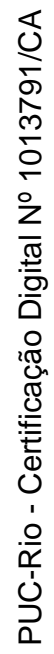

Li Lítio

Mn Manganês

MP Materiais Particulados

$\mathrm{NO}_{2}$ Dióxido de Nitrogênio

$\mathrm{NO}_{x}$ Óxidos de Nitrogênio

Ni Níquel

NMVOC. Não Metano Volátil Orgânico Composto

$\mathrm{N}_{2}$ Nitrogênio

$\mathrm{N}_{2} \mathrm{O}$ Óxido nitroso

$\mathrm{O}_{2}$ Oxigênio

$\mathrm{O}_{3}$ Ozônio

$\mathrm{Pb}$ Chumbo

PFCs - Perfluorcarbonos

$\mathrm{SF}_{6}$ Hexafluoreto de Enxofre

$\mathrm{SO}_{2}$ Dióxido de Enxofre

$\mathrm{SO}_{\mathrm{x}}$ Óxido de enxofre

Zn Zinco

(dB) A Decibel 
"Na natureza nada se cria, nada se perde, tudo se transforma." Antoine Lavoisier (séc. XVIII). 


\section{INTRODUÇÃO}

\section{1}

\section{Consumo sustentável}

$\mathrm{Na}$ definição do Programa das Nações Unidas para o meio ambiente (PNUD) ${ }^{1}$, consumo sustentável significa o fornecimento de serviços e produtos correlatos que atendam às necessidades básicas do ser humano e promovam sua melhor qualidade de vida não só atual, como das gerações futuras. Por isso mesmo, consumo sustentável importa na especial atenção para o uso de recursos naturais e de substâncias tóxicas e bem assim no rigoroso controle das emissões de resíduos e poluentes durante o ciclo de vida do produto ou do serviço.

Em cenário de mudanças climáticas, com o consumo cada vez maior de bens descartáveis e de energia e o consequente aumento da produção de lixo impõe-se adotar estilos de vida mais sustentáveis, compatíveis com menores taxas de utilização dos recursos naturais e dos níveis das emissões dos gases que provocam o efeito estufa.

Por outro lado, faz-se imprescindível desvincular o crescimento econômico de uma automática degradação do meio ambiente (noção central no sistema econômico produtivista). Isto serve tanto para países em desenvolvimento como para os desenvolvidos. Tudo sem perder de vista a melhoria das condições de vida das camadas mais pobres, ajudando-as a alcançá-las e delas desfrutar em um ambiente sadio e equilibrado, muito embora grande parte da população mundial ainda esteja consumindo muito pouco, até mesmo para atender suas necessidades básicas.

Como adverte Resende (2011), responder a estes desafios vai exigir uma combinação de novas políticas, investimentos redirecionados, aplicações de tecnologias ambientais sadias, cooperação internacional e capacitação para

\footnotetext{
${ }^{1}$ PNUD Programa das Nações Unidas para o Desenvolvimento. Tem como objetivo contribuir para o desenvolvimento humano, o combate à pobreza e o crescimento dos países nas áreas prioritárias, entre elas garantir a sustentabilidade mundial.
} 
reformular as economias nacionais. E uma revisão das bases da economia global, principalmente por estar hoje baseada no consumo de energia originada de combustíveis fósseis.

Mais do que em qualquer outra época, a humanidade se encontra em uma encruzilhada. Desde a Revolução Industrial, na visão econômica tradicional, considera-se que a tecnologia e o mercado sempre serão capazes de encontrar substitutos para recursos naturais esgotados e soluções para a degradação ambiental.

O homem necessita de energia para realizar a maioria de suas atividades cotidianas. Essa energia provém de fontes primárias como petróleo, carvão, gás (não renováveis), ou se reveste de outra natureza, como ocorre com a biomassa, a energia solar e a hidráulica e o biogás (renováveis). O desenvolvimento futuro depende da disponibilidade de energia por muito tempo em quantidades cada vez maiores e de fontes seguras, confiáveis e adequadas ao meio ambiente.

Os combustíveis fósseis tornaram possível o desenvolvimento industrial que hoje garante uma contínua melhoria das condições sociais, mas, de outro lado, vem gerando também um aumento da demanda de energia e uma distribuição global extremamente desigual de energia primária. (Comissão Mundial Sobre Meio Ambiente e Desenvolvimento, 1988).

A matriz energética mundial tem participação total de $80 \%$ de fontes de Carbono (36\% de petróleo, $23 \%$ de carvão, e $21 \%$ de gás natural). É importante ressaltar, que a recente crise energética e a alta de preços dos combustíveis fósseis têm determinado uma procura por alternativas economicamente viáveis e menos poluidoras. Daí os inúmeros estudos para utilização de energias renováveis.

As pressões de cunho social (emprego, renda, fluxos migratórios e ambientais, mudanças climáticas, poluição) apenas reforçam e consolidam essa procura, além de antecipar os cronogramas de implantação de tecnologias energéticas mais limpas.

A extração intensiva de materiais e as emissões de substâncias tóxicas agridem a natureza e, por excederem a capacidade de absorção da biosfera, alteram o equilíbrio ecológico do planeta. (PÓLIS, 1998).

Em um país como o Brasil, onde a produção monumental de resíduos sólidos urbanos ("RSU”) causa enormes impactos socioambientais, a inclusão do 
biogás na sua matriz energética é uma alternativa promissora. (TRIGUEIRO, 2013).

\section{2}

\section{Objetivo}

O objetivo principal deste trabalho é estudar a possibilidade de mudança de combustível em caminhões compactadores coletores de lixo domiciliar /público e apresentar propostas para reduzir os efeitos das emissões de gases poluentes resultantes da coleta e da decomposição dos resíduos sólidos urbanos ("RSU”) nos aterros sanitários.

O diesel de origem mineral, combustível usado neste tipo de veículo, seria substituído, total ou parcialmente, por biogás/GNV e/ou eletricidade, produzido pelo biogás de aterro, sugerindo alternativas para estabelecer uma nova dinâmica nos sistemas de limpeza urbana, garantindo ganhos econômicos e ambientais para a população.

Segundo estudo do Banco Mundial (2004), a viabilidade da captação e a utilização de biogás é normalmente limitada a grandes e profundos aterros (acima de 1 milhão de tonelada de resíduos e profundidade de mais de 15 metros) e para cidades com pelo menos 400.00 habitantes ou que possam estabelecer uma relação de compartilhamento de aterro com municípios vizinhos, para que possam gerar energia com o gás do lixo.

$\mathrm{O}$ aterro de Jardim Gramacho (RJ), apesar de não receber mais resíduos desde 2012, servirá, aqui, como modelo para testar a possibilidade da sua replicação em outros aterros de cidades brasileiras. Com uma produção diária de aproximadamente de $480.000 \mathrm{~m}^{3}$ de biogás, qual seria a porcentagem do seu aproveitamento como combustível para o abastecimento na frota de coleta de caminhões coletores compactadores da Companhia Municipal de Limpeza Urbana, RJ, (COMLURB). E quanto (e se) sobraria para ser utilizado como energia para ser injetada na rede (elétrica ou gás), abrindo novas perspectivas para o seu aproveitamento econômico.

Compreende, ainda, uma análise comparativa entre as diversas formas de tratamento e coleta de resíduos no Rio de Janeiro, no Brasil e em alguns países do mundo. 


\section{2}

\section{RSU E O MEIO AMBIENTE}

\section{1}

\section{O lixo, um problema desde sempre}

A produção de resíduos é uma característica associada à presença humana e desde sempre existiu. No início dos tempos, os primeiros homens eram nômades. Moravam em cavernas, sobreviviam da caça e pesca, vestiam-se de peles e formavam uma diminuta população sobre a terra. Quando a comida escasseava, mudavam-se para outra região e os seus "lixos", deixados sobre o meio ambiente, eram logo decompostos pela ação do tempo sem causar impactos negativos à natureza. (GERESOL, 1999).

Nas sociedades primitivas, quando a atividade principal era caçar e apanhar frutos das árvores, o lixo era biodegradável. A produção de lixo começa a aumentar com o surgimento das cidades e com o crescimento populacional. Os grandes agrupamentos humanos passaram a se fixar em determinadas áreas, não mais comportando, exatamente em função do seu crescimento, a deslocação de um lugar para outro. Desde então, o acúmulo de resíduos tornou-se um problema.

Com o passar dos anos, a abertura de valas para enterrar resíduos pareceu suficiente para contornar o inconveniente aparecimento dos insetos e roedores perto dos locais onde era depositado o lixo,

Durante o século XIX, com o desenvolvimento da medicina e da engenharia sanitária, reconheceu-se desde logo que os dejetos humanos, se não tivessem coleta, tratamento e destino adequados, eram uma potente fonte de doenças, que poderiam levar a epidemias explosivas. (MONTEIRO, 2001).

A substituição da tração animal pelo transporte motorizado também resultou na eliminação de outra parcela de resíduos dos logradouros: os dejetos animais, em sua quase totalidade (excetuando-se os referentes aos cães).

Ainda no século XIX, a ciência revelou a relação entre os ratos, moscas e baratas e lixo nas ruas e a forma de transmissão de doenças através desses vetores. 
Adotaram-se desde então providências efetivas para que o lixo fosse coletado nos domicílios, em vez de permitir fosse simplesmente atirado às ruas ou em terrenos.

A pavimentação das vias públicas e o ensino de princípios de higiene e saúde pública nas escolas também contribuíram para a redução dos resíduos nos logradouros. A figura 1 exemplifica a evolução dos veículos de coleta de RSU.
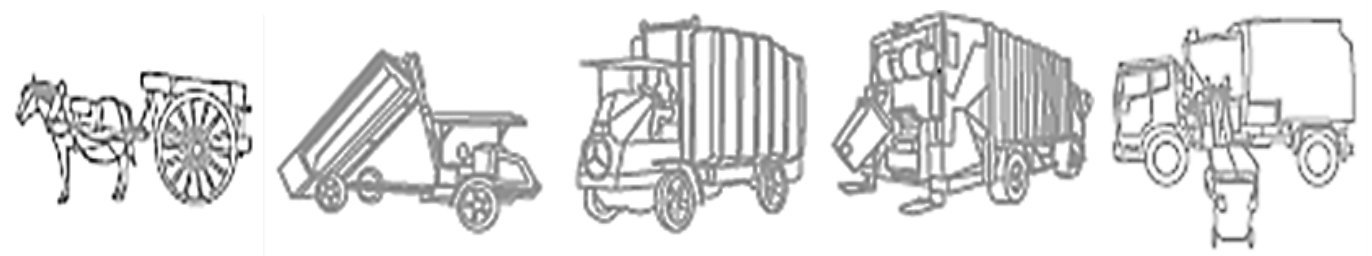

Figura 1 - Evolução dos veículos de coleta de RSU. Fonte: VEOLIA (2012).

O saneamento inadequado das cidades é, ainda hoje, uma das principais causas de doenças, além de significativos prejuízos econômicos. A eficiência da gestão dos resíduos é, assim, uma condição imprescindível para a melhoria da qualidade ambiental. (PRICEWATERHOUSECOOPERS, 2010).

A expansão das cidades, as grandes aglomerações populacionais, as mudanças de hábitos e o desenvolvimento industrial (mais embalagens descartáveis e outros materiais inertes), segundo Ensinas (2003), agravam os problemas da destinação final dos RSU. O fato de os resíduos deixarem de ter valor econômico após o descarte não os faz desaparecer. Coletá-los e dar- lhes uma destinação adequada torna-se um enorme desafio para governos, cientistas, indústrias e a população em geral.

Nos grandes centros, o aumento da geração de resíduos é bastante superior ao crescimento da população; milhares de toneladas de lixo são despejadas diariamente em lixões ou aterros sanitários, exigindo investimentos maiores e proporcionais (PRICEWATERHOUSECOOPERS, 2010). A figura 2 exibe o crescimento da população urbana em comparação com a rural no Brasil. 


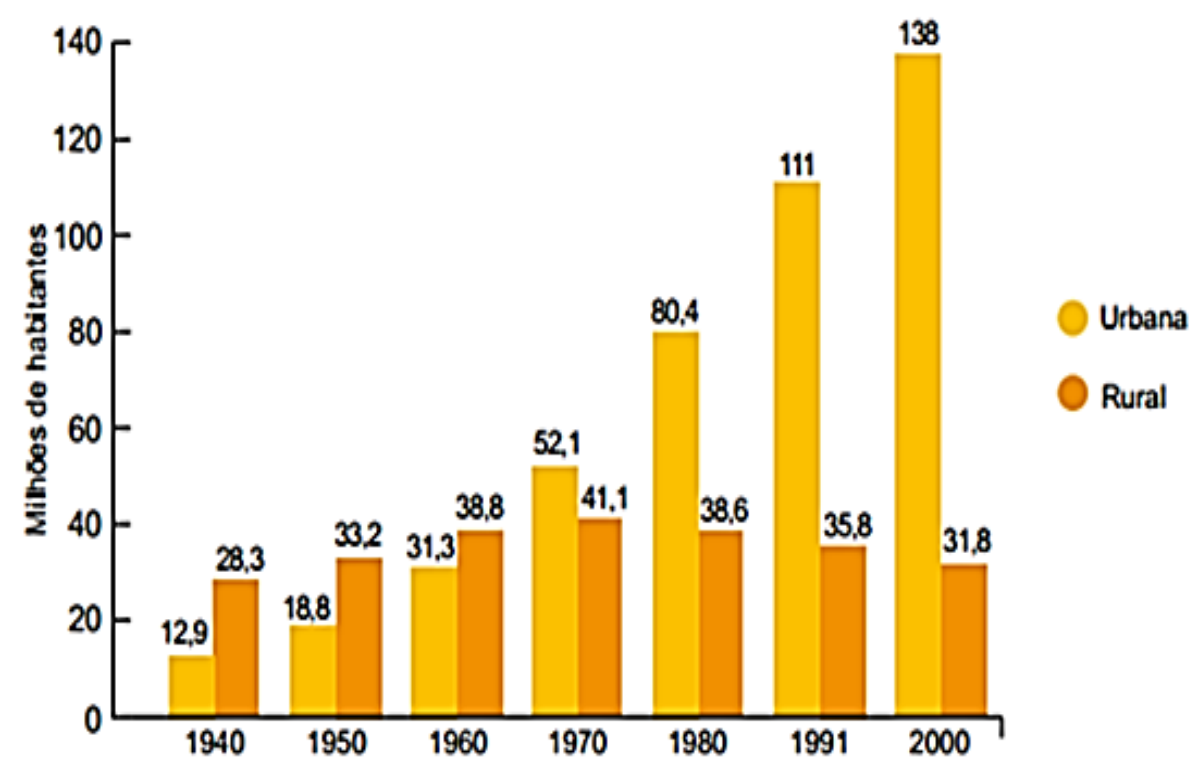

Figura 2 - Proporção entre a população urbana e rural entre 1940/2000.

Fonte: (IBGE, 2001).

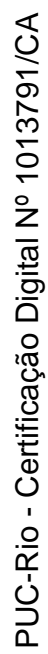

A população brasileira aumentou $12 \%$ nos últimos dez anos (IBGE, 2010) e a produção de resíduos, no mesmo período, 90\% (Figura 3). Segundo a Associação Brasileira de Empresas de Limpeza Pública e Resíduos Especiais (ABRELPE, 2011), a geração de RSU per capita cresceu 5,3\% entre 2009 e 2010. (PRICEWATERHOUSECOOPERS, 2011).

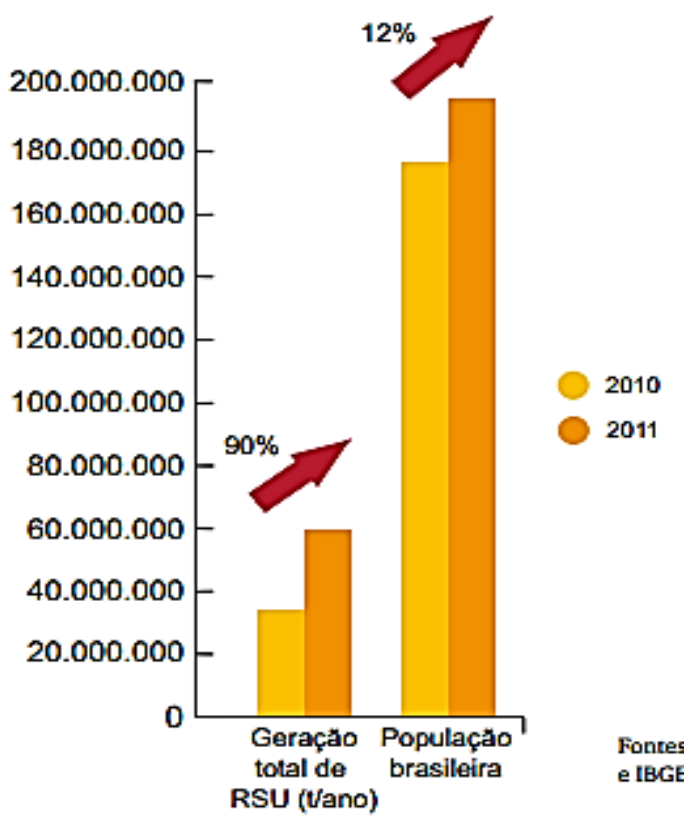

Figura 3 - Evolução da geração de RSU e evolução da população entre 2000 e 2010 no Brasil. Fonte: PRICEWATERHOUSECOOPERS (2011). 
De acordo com a ONU (Organização das Nações Unidas, 2012), a população mundial passará de 7 bilhões para 9 bilhões em 2050. Considerada a migração de áreas rurais para as áreas urbanas, esse crescimento fará com que 6,3 bilhões de pessoas vivam em cidades em 2050, comparados aos 3,5 bilhões atuais.

Entre as questões que devem ocupar os pesquisadores, pelos impactos que causam no meio ambiente, coloca-se a do lixo urbano, vale dizer, a dos RSU.

\section{2}

\section{Destinação final adequada dos RSU (realidade brasileira)}

Dentre as possibilidades de destinação final dos RSU, a utilização de aterros sanitários apresenta-se como uma das alternativas mais econômicas. É a forma de tratamento mais usada ainda no Brasil e na maioria dos países do mundo, principalmente aqueles que possuem grande extensão territorial, em razão dos menores custos operacionais, da facilidade de execução e da grande capacidade de absorção de resíduos, quando comparada às outras formas de destinação final (ou tratamento), como a incineração, a compostagem e a reciclagem. (CETESB, 2012).

A maior parte dos materiais encontrados no lixo urbano é, na realidade, uma combinação de várias substâncias provenientes dos mais diferentes pontos do planeta e, teoricamente, pode e deve ser reciclada. No Brasil, contudo, é tarefa praticamente inviável. Fatores de ordem técnica e econômica dificultam grande parte do processo de reciclagem, deixando como alternativa o descarte em aterro. Os métodos de acondicionamento e coleta utilizados na quase totalidade das cidades brasileiras misturam estes materiais, tornando difícil sua separação pelos processos de triagem atualmente utilizados. Como consequência, tanto as usinas de compostagem, quanto as técnicas de coleta seletiva de rejeitos acabam produzindo materiais que obrigatoriamente devem ser desprezados. Mesmo os incineradores, que, em tese, reduzem os resíduos de 5 a $15 \%$ do volume original dos resíduos, geram escórias e cinzas que acabam depositadas nos aterros.

É certo ainda que não se pode desconsiderar a realidade dos países do terceiro mundo. Nem sempre a comunidade dispõe de recursos suficientes para a implantação e operação de um adequado sistema de tratamento de seus resíduos. (CETESB, 2013), 


\section{3}

\section{Matéria orgânica dos RSU e o biogás}

Os RSU dispostos nos aterros contém significativa parcela de matéria orgânica; pela ação de microrganismos ocorre sua degradação, transformando-a em um gás conhecido como biogás. Na maioria dos aterros sanitários brasileiros, a matéria orgânica é superior a 50\% conforme se vê na figura 4. E o biogás gerado, tem, como característica básica, uma concentração acima de $30 \%$ de $\mathrm{CO}_{2}$ (Dióxido de Carbono) e de 50-55\% de $\mathrm{CH}_{4}$ (Metano), aproximadamente. Este último gás é passível de ser captado e aproveitado como fonte renovável de energia, em virtude do seu alto poder calorífico. Países desenvolvidos já aplicam tecnologias para o aproveitamento energético dos RSU com diferentes finalidades, entre elas a geração de eletricidade, o uso direto em indústrias e como combustível para veículos (GNV). (ENSINAS, 2003).

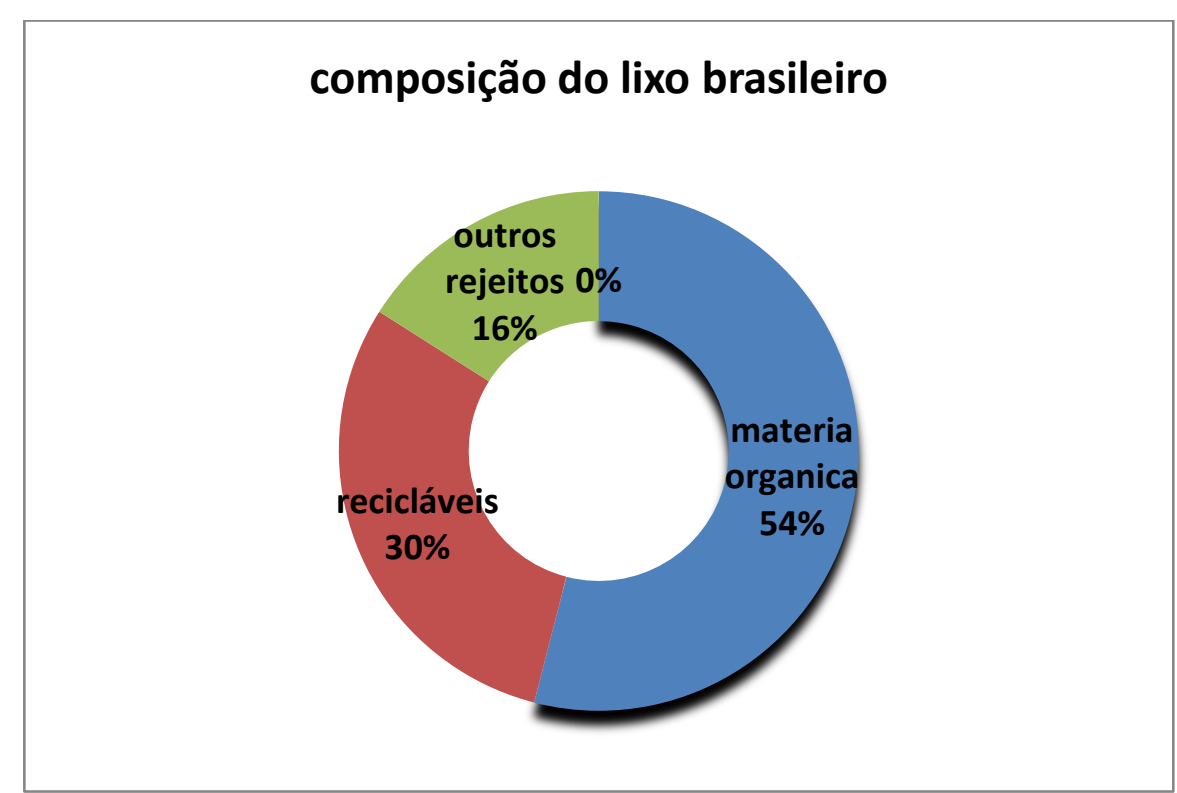

Figura 4 - Estimativa da produção de RSU no Brasil. Fonte:Revista VEJA, 2011.

Segundo estudo do Banco Mundial (2004), grande parte do biogás que será gerado nos próximos 20 anos é resultado do que está sendo hoje depositado nos aterros sanitários. Assim sendo, os projetos de gestão do biogás de aterro devem ser fundamentais em qualquer estratégia de planejamento energético, e serem incluídos dentro de um sistema de manejo dos RSU. São significativos os recursos financeiros que daí advém e constituem incentivo para melhora do próprio 
sistema, assim como para as condições gerais da limpeza urbana. (PRICEWATERHOUSECOOPERS, 2010).

\section{4}

\section{Poluição atmosférica}

A poluição atmosférica pode ser definida como resultante de qualquer forma de matéria ou energia com intensidade, concentração, tempo ou características que possam tornar o ar impróprio, nocivo ou ofensivo à saúde, inconveniente ao bem-estar público, danoso aos materiais, à fauna e à flora ou prejudicial à segurança, ao uso e gozo da propriedade e à qualidade de vida da comunidade.

De uma forma geral, a qualidade do ar é produto da interação de um complexo conjunto de fatores dentre os quais se destacam a magnitude das emissões, a topografia e as condições meteorológicas da região, favoráveis ou não à dispersão dos poluentes. Frequentemente, os efeitos da má qualidade do ar não são tão visíveis quando comparados a outros mais fáceis de serem identificados.

A poluição do ar pode também afetar ainda a qualidade dos materiais (corrosão), do solo e das águas (chuvas ácidas) e afetar a visibilidade. (MMA, Ministério do Meio Ambiente, 2012)

Basicamente, os RSU estão associados a dois fatores de emissões de gases: (a) o sistema de coleta por caminhões alimentados por combustíveis fósseis. e (b) os aterros sanitários, a cada ano 7 milhões de toneladas de metano $\left(\mathrm{CH}_{4}\right)$ vão para a atmosfera (COMLURB, 2011).

\subsection{1}

\section{Poluição do ar associada aos transportes de RSU}

As emissões de origem veicular são resultado da queima do combustível ou da sua evaporação. Os poluentes primários emitidos pelos veículos automotores incluem o Dióxido de carbono $\left(\mathrm{CO}_{2}\right)$, Monóxido de carbono (CO), hidrocarbonetos $(\mathrm{HC})$, Dióxido de enxofre $\left(\mathrm{SO}_{2}\right)$, Óxidos de nitrogênio $\left(\mathrm{NO}_{\mathrm{x}}\right)$ e materiais particulados (MP). 
Os poluentes secundários associados às emissões veiculares incluem o), oxidantes fotoquímicos (Ozônio), ácido sulfúrico, ácido nítrico e seus sais (aerossóis de sulfatos e nitratos).

Os veículos automotores são a principal fonte de poluição nos grandes centros urbanos, onde existem em maior número.

Nesse contexto, o custo do transporte público está subestimado, pois desconsidera todo o dano decorrente dessa poluição. Assim, a transição do diesel para o gás natural ou opção por veículos elétricos representa um benefício, não só por diminuir as emissões de poluentes e sua concentração atmosférica, como por reduzir o custo social.

Em suma, os custos associados à poluição do ar são crescentes. Quanto mais se poluir o ar, maior será o custo social pela incidência de doenças respiratórias, morbidade e mortalidade precoce. As populações mais vulneráveis são as crianças, os idosos e as pessoas que já apresentam doenças respiratórias.

Assim, a avaliação econômica das alternativas que reduzam o esse custo, como o uso de um combustível mais limpo, deve incorporar o valor do benefício social ao reduzir tais externalidades. (RIBEIRO, 2005).

Os tipos de compostos (partículas) e seus impactos da poluição no meio ambiente e nos indivíduos são relacionados abaixo:

- Partículas totais em suspensão (PTS) - poeira, neblina, aerossol, fumaça e fuligem - quanto menor o seu tamanho, maior o dano à saúde. Essas partículas causam efeitos significativos em pessoas com doença pulmonar, principalmente asma e bronquite.

- Partículas inaláveis (MP) e fumaça - causam aumento no atendimento em hospitais, devido a problemas respiratórios em alguns casos, ocasionando morte prematura.

- Óxidos de enxofre $\left(\mathrm{SO}_{2}\right)$ - gás incolor, com forte odor, semelhante ao gás produzido na queima de palitos de fósforo - tem como efeito o desconforto na respiração, agravamento ou surgimento de doenças respiratórias, cardiovasculares e asmáticas, além de acentuar doenças crônicas do coração e pulmão que são mais sensíveis ao $\mathrm{SO}_{2}$. 
- Óxidos de nitrogênio (NO $\mathbf{N}_{\mathbf{x}}$ - gás marrom avermelhado, com odor forte e muito irritante - diminui a resistência às infecções respiratórias nos indivíduos e aumenta a sensibilidade à asma e bronquite.

- Monóxido de carbono (CO) - gás incolor, inodoro e insípido - altos níveis desse gás ocasionam no ser humano prejuízo nos reflexos, na capacidade de estimar intervalos de tempo e no aprendizado.

- Aldeídos - compostos orgânicos - ocasionam irritação nos olhos, nariz e garganta, além de ser agente cancerígeno.

- Ozônio $\left(\mathbf{O}_{3}\right)$ - gás incolor e inodoro - causa irritação nos olhos e vias respiratórias e diminui a capacidade pulmonar. Altas concentrações desse gás podem resultar em sensações de aperto no peito e tosse.

- Hidrocarbonetos (HC) - compostos orgânicos - provocam irritação nos olhos, nariz, pele e aparelho respiratório, além de serem cancerígenos e mutagênicos.

\subsection{2}

O uso do (bio)diesel na coleta de RSU e a poluição emitida no Brasil

Estudo realizado com 15,7 mil veículos em todo o Brasil constatou que o transporte de lixo é o que mais emite Dióxido de carbono por quilômetro rodado. De acordo com o levantamento feito por uma empresa de gerenciamento de frotas, (ECOFROTAS, 2011) caminhões de coleta de lixo emitem cerca de 1,24 kg de $\mathrm{CO}_{2}$ por quilômetro rodado. Em segundo lugar, estão os usados no setor químico, que emitem em média $1,11 \mathrm{~kg}$ do gás por $\mathrm{Km}$, e em terceiro lugar as máquinas agrícolas pesadas com $1,02 \mathrm{~kg}$ de $\mathrm{CO}_{2}$. Os que menos emitem são os veículos usados em emergências médicas com $0,36 \mathrm{~kg}$ de $\mathrm{CO}_{2}$ por $\mathrm{Km}$, e os do setor de mineração com $0,34 \mathrm{~kg}$ por $\mathrm{Km}$.

A alta emissão de $\mathrm{CO}_{2}$ dos caminhões de lixo está mais relacionada com a característica da operação e do uso de diesel do que com a gestão de manutenção dos veículos. É uma atividade onde muitas vezes o caminhão não passa a segunda 
marcha, o que gera um consumo elevado. O caminhão anda e para, de maneira que permite ao lixeiro que recolha o lixo em todos os pontos. (ABETRE,2011 ${ }^{2}$ ).

As características da frota circulante influenciam a emissão de poluentes, especialmente quando considerada sua manutenção. É de se esperar que os veículos mais novos sejam menos poluidores devido à introdução de tecnologias e limites de emissão mais restritivos. Todavia, em alguns casos, veículos relativamente novos e sem manutenção podem emitir mais do que veículos antigos bem conservados.

Para Meyer (2001), o comportamento do usuário e as características do tráfego influenciam as emissões principalmente no que diz respeito ao modo de operação do veículo. Uma série de curtas viagens gera mais emissão do que uma única longa viagem de distância equivalente. Outro fator operacional é a velocidade média. As emissões são maiores em tráfegos lentos e congestionados, menores em velocidades intermediárias. Demais fatores seriam os tipos de motores, tipo de combustíveis, tamanho e carga. A capacidade das vias também influencia as emissões, o que reforça a necessidade de um planejamento do setor de transporte como um todo e não de cada veículo individualmente.

Na maioria das grandes cidades brasileiras, a coleta é feita com caminhões movidos a diesel nos quais os contêineres são encaixados e basculados diretamente no veículo.

Neste cenário, o que o Brasil faz para reduzir as emissões de gases é adicionar 5\% de biodiesel, (que é um combustível produzido a partir de fontes naturais renováveis), ao diesel mineral utilizado.

Segundo estudo da PETROBRÁS (2010), o biodiesel é produzido pela reação química do óleo vegetal com um álcool de cadeia curta (metanol ou etanol). Como regra geral, $100 \mathrm{~kg}$ de óleo reagem com $10 \mathrm{~kg}$ de álcool gerando $100 \mathrm{~kg}$ de biodiesel e $10 \mathrm{~kg}$ de glicerina. Qualquer veículo movido a diesel pode utilizar o biodiesel sem necessidade de adaptação, inclusive motores de 2 tempos.

O uso do biodiesel reduz as emissões do monóxido de carbono $(\mathrm{CO})$, do material particulado (MP), do óxido de enxofre $\left(\mathrm{SO}_{\mathrm{x}}\right)$, dos hidrocarbonetos totais (HC) e de grande parte dos hidrocarbonetos tóxicos. O biodiesel de referência é o originário de óleo de soja. Contudo, cientistas da União Europeia mostraram que

\footnotetext{
${ }^{2}$ ABETRE - Associação Brasileira de Empresas de Tratamento de Resíduos.
} 
existe um aumento das emissões de $\mathrm{NO}_{\mathrm{x}}$ (óxidos de Nitrogênio) associado ao biodiesel em relação às do diesel de petróleo. Este elemento é essencial para formação do ozônio troposférico $\left(\mathrm{O}_{3}\right)$, zona atmosférica mais próxima do solo. A presença do $\mathrm{NO}_{\mathrm{x}}$ é um dos grandes responsáveis pela má qualidade do ar das principais cidades brasileiras, provocando o smog, e está relacionado ao aumento de casos de doenças pulmonares.

\subsection{3}

\section{Desvantagens associadas ao biodiesel}

- Consome grande quantidade de energia para a produção;

- Aumenta o consumo de água (para irrigação das culturas);

- Reduz a biodiversidade;

- As culturas para produção de biocombustíveis consomem muitos fertilizantes nitrogenados, com liberação de óxidos de nitrogênio, que também são gases estufa;

- Devastação de áreas florestais (grandes consumidoras de $\mathrm{CO}_{2}$ ) para plantio das espécies envolvidas na produção dos biocombustíveis;

- Possibilidade de redução da produção de alimentos em detrimento do aumento da produção de biocombustíveis, o que pode contribuir para incremento da fome no mundo e o encarecimento dos alimentos;

- Contaminação de lençóis freáticos por nitritos e nitratos, provenientes de fertilizantes; a ingestão desses produtos causa problemas respiratórios.

\section{5}

\section{Emissões de gases de efeito estufa}

Além da poluição emitida pelos transportes de RSU, a USEPA (United States Environment Protection Agency, 2012), afirma que os aterros de RSU são a terceira maior fonte humana geradora das emissões de metano $\left(\mathrm{CH}_{4}\right)$ nos Estados Unidos, liberando, apenas em 2009, cerca de 27,5 milhões de toneladas de carbono equivalente para a atmosfera. As estimativas das emissões globais de 
metano, provenientes dos aterros, oscilam entre 20 e $70 \mathrm{Tg}$ /ano, enquanto o total das emissões pelas fontes antropogênicas equivale a $360 \mathrm{Tg} / \mathrm{ano}$, indicando que os aterros podem produzir cerca de 6 a $20 \%$ do total de metano (IPCC, 1995).

O biogás dos aterros contém não só o Metano $\left(\mathrm{CH}_{4}\right)$, como o Dióxido de carbono $\left(\mathrm{CO}_{2}\right)$, ambos responsáveis pelo efeito estufa e, pois, pelo aquecimento global. O Metano $\left(\mathrm{CH}_{4}\right)$ é um gás incolor e inodoro. Considerado um dos mais simples hidrocarbonetos (figura 5), tem pouca solubilidade na água (FARIA, 2010). Possui um elevado potencial energético (energia química), em função das ligações entre os átomos de Hidrogênio e Carbono; libera grande quantidade de calor (energia térmica) quando reage com o Oxigênio. É um gás de fácil combustão e, por isso, há sempre o risco de explosões onde é gerado. (ICLEI, 2009).

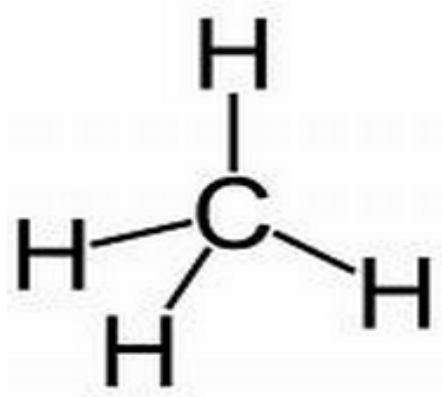

Figura 5 - Fórmula estrutural do metano. Fonte: Sua pesquisa.com.

O Metano $\left(\mathrm{CH}_{4}\right)$ é produzido através dos seguintes processos naturais:

- Decomposição da matéria orgânica dos RSU;

- Digestão de animais herbívoros;

- Metabolismo de certos tipos de bactérias;

- Vulcões de lama;

- Extração de combustíveis minerais (principalmente o petróleo);

- Aquecimento de biomassa anaeróbia.

O poder calorífico do Metano $\left(\mathrm{CH}_{4}\right)$ é 21 vezes maior que o do Dióxido de carbono $\left(\mathrm{CO}_{2}\right)$. Considerando um período de 100 anos, 1 grama de Metano contribui 21 vezes mais para a formação do efeito estufa do que 1 grama de Dióxido de carbono. (IPCC, 1996). Mas, o Metano tem uma vida atmosférica 
curta (+-10 anos). Como é potente e de curta duração, reduzir suas emissões nos aterros de RSU é uma das melhores formas de, a curto prazo, mitigar a mudança climática global.

$\mathrm{Na}$ atmosfera, o Metano é encontrado na proporção aproximada de 1,7 p.p.m (partículas por milhão de Dióxido de carbono equivalente) - uma medida uniforme criada para expressar o potencial de aquecimento de todos os gases de efeito estufa (GEE) e este número aumenta a uma taxa anual de 1,5/2 p.p.m. (PNUMA, 2012).

Em 2013, pela primeira vez na história da humanidade, atingiu-se a marca de 400 p.p.m de concentração de $\mathrm{CO}_{2}$ na atmosfera, cuja maior causa é a queima progressiva de combustíveis fósseis. É impressionante a velocidade com que o principal gás de efeito estufa vem se acumulando (280 p.p.m. antes da Revolução Industrial, 320 p.p.m na década de 1950). Parcela majoritária da comunidade científica, diante da iminente ultrapassagem do índice de 450 p.p.m. considerado uma medida simbólica - que marca uma tendência preocupante na direção do agravamento do efeito estufa - indica que as mudanças em curso deverão causar mais problemas econômicos, sociais e ambientais em escala global. (TRIGUEIRO, 2013).

As emissões de $\mathrm{CO}_{2}$ de aterros de RSU não são consideradas porque o carbono contido na biomassa viva (matéria orgânica) seria emitido de qualquer maneira como resultado da decomposição natural fora do ambiente do aterro. (USEPA, 2012).

Hoje em dia, utilizam-se indistintamente os termos "efeito estufa", "aquecimento global” e "mudanças climáticas", que, embora estejam relacionados entre si, possuem significados diferentes.

O efeito estufa é um fenômeno natural e necessário, pelo qual parte do calor emitido pela superfície da Terra, em decorrência dos raios solares, fica retido nas camadas baixas da atmosfera, conservando uma faixa de temperatura adequada para a manutenção da vida no planeta. Sem essa ação, sua temperatura seria de aproximadamente $-18^{\circ} \mathrm{C}$. (RIBEIRO, 2005).

De suma importância para diversas espécies biológicas, o efeito estufa acontece principalmente pela ação do Dióxido de carbono, clorofluorcarbonetos, Metano, óxido nitroso e vapor de água, que juntos formam uma barreira contra a dissipação da energia solar, conforme ilustra a figura 6. 


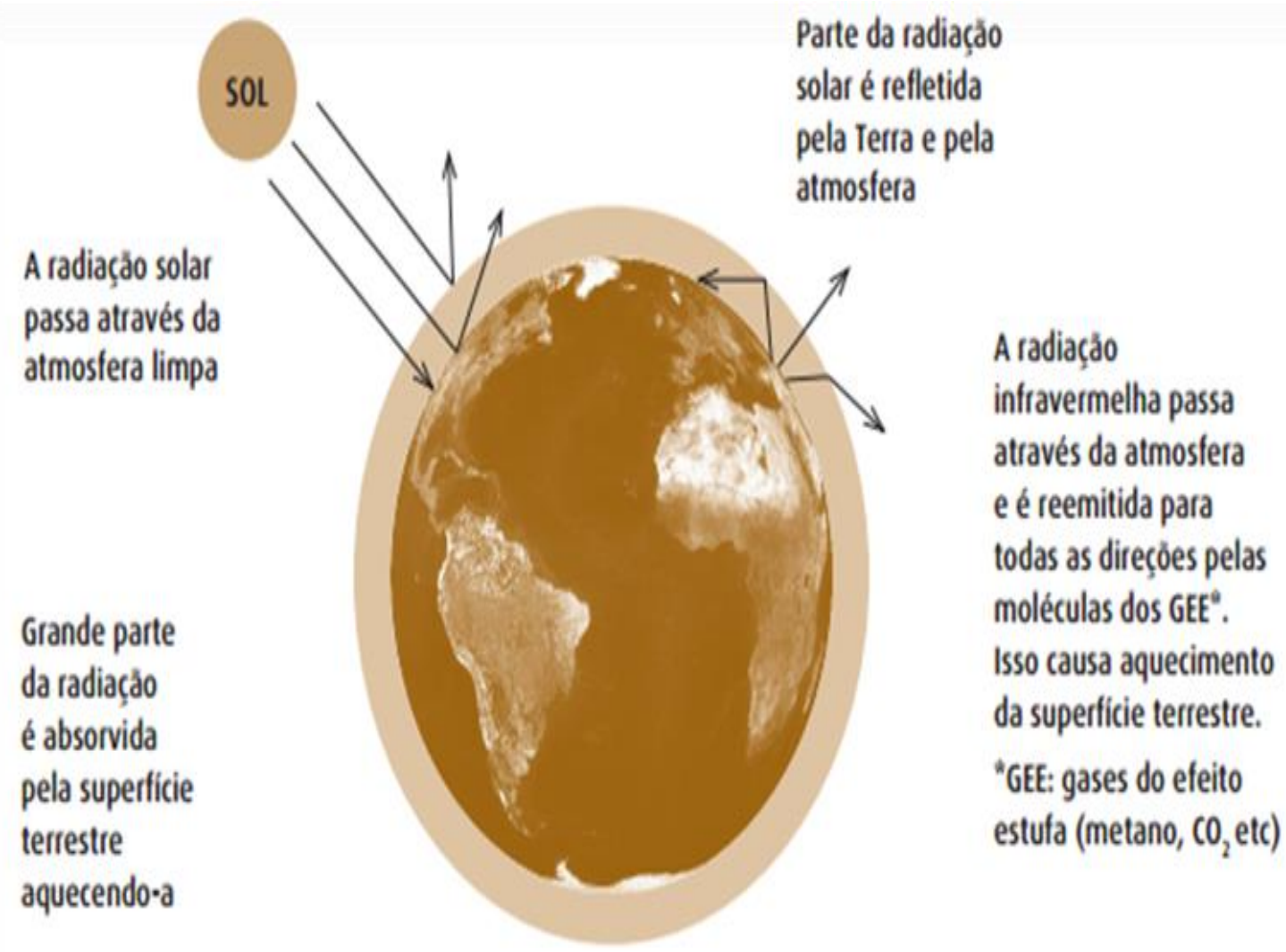

Figura 6 - Esquema do efeito estufa. Fonte: Felipetto (2005).

O aquecimento global é o resultado da intensificação do efeito estufa natural. Decorre do aumento da concentração de gases na atmosfera, inclusive gases sintéticos que agridem a camada de ozônio. Essa barreira de poluentes funciona como um isolante térmico.

O aquecimento traz como consequências importantes mudanças climáticas, como a elevação da temperatura média e o maior derretimento das geleiras das regiões polares e das que ficam em grandes altitudes. Ocasionam ainda a dilatação dos oceanos, mudanças nos ciclos hidrológicos e fenômenos atmosféricos diversos: ondas de calor inéditas, furacões avassaladores, secas intermináveis onde antes havia água em abundância, enchentes devastadoras, tsunamis, incêndios florestais e todo tipo de desastres naturais que fogem ao controle humano (ICLEI, 2009). Provocam ainda a extinção espécies de animais e plantas O aumento de GEE (gases de efeito estufa) ameaça colocar a Terra num caminho irreversível para um clima imprevisivelmente diferente. (PNUMA, 2012).

A NASA (National Aeronautics and Space Administration, 2011) analisou, para cada setor da economia, as ações de várias espécies químicas $\left(\mathrm{CO}_{2}, \mathrm{NO}_{2}\right.$, 
$\mathrm{CH}_{4}, \mathrm{O}_{3}$, nitratos e os chamados carbono orgânico e carbono negro), ${ }^{3}$ no aquecimento e resfriamento da terra. Apontou o transporte rodoviário como o grande vilão do aquecimento global.

$\mathrm{Na}$ análise, não foi considerada a quantidade de emissão destes agentes químicos poluentes, mas seu potencial para aquecer ou resfriar a Terra. Cada setor da economia, como o de transporte terrestre ou agricultura emite uma combinação única de gases que afetam o clima de diferentes maneiras e em diferentes escalas de tempo. Foram estudadas as emissões de 13 setores, de 2000 até 2011, e projetados cenários até 2100 . O resultado foi apontar os veículos motorizados como os que mais contribuem para o aquecimento da Terra, agora e no futuro próximo. O estudo mostra que, mesmo não sendo o principal em termos totais de emissões, carros, ônibus e caminhões têm a combinação de poluentes mais poderosa para a elevação da temperatura na Terra.

A agência americana evidenciou que a queima de biocombustíveis domésticos, principalmente madeira e esterco animal para aquecimento, e a pecuária, em especial, com o metano produzido pelo gado, ficam em segundo e terceiro lugares respectivamente. Até 2100 , as fontes de produção de energia passarão a ser as maiores promotoras do aquecimento global, com os transportes ficando como o segundo.

\subsection{1}

\section{Potencial de aquecimento global e as emissões brasileiras}

O Dióxido de carbono $\left(\mathrm{CO}_{2}\right)$ é o gás responsável por mais da metade do aquecimento global. Outros gases provocam o mesmo efeito, porém com intensidades maiores, expressas em toneladas equivalentes de $\mathrm{CO}_{2}$, conforme pode ser vista na Tabela 1. (ICLEI, 2009).

\footnotetext{
${ }^{3}$ Carbono negro é uma mistura antropogênica de sulfato, cinzas, material orgânico, poeira, nitrato e aerossóis naturais, que também dão origem à produção regional de nevoas de coloração acastanhada ou mais conhecidas como nuvens marrons atmosféricas. Em termos de estimar os efeitos de radiação, o carbono negro é definido como a massa de carbono elementar que absorve a mesma quantidade de luz que as partículas emitidas, daí a alcunha de "negro", (contudo, nem todas as formas de carbono que absorvem luz são de coloração escura e a forma molecular difere da do carbono elementar). O carbono negro é produzido principalmente através da combustão incompleta de biomassa sólida, carvão ou diesel.
} 
Tabela 1 - Principais Gases de Efeito Estufa, suas origens e potencial de aquecimento global.

\begin{tabular}{|c|c|c|}
\hline Gases do Efeito Estufa & $\begin{array}{c}\text { Potencial de Aquecimento } \\
\text { Global (100 anos) }\end{array}$ & Principais causas \\
\hline $\mathrm{CO}_{2}$ (Dióxido de carbono) & $\begin{array}{l}1 \times \mathrm{CO}_{2} \text { e equivalente } \\
\text { (valor de referência) }\end{array}$ & $\begin{array}{l}\text { Uso intensivo de combustíveis } \\
\text { fósseis, aumento da } \\
\text { ocorrência de queimadas e } \\
\text { incêndios florestais, que } \\
\text { provocam o aumento das } \\
\text { emissões de } \mathrm{CO}_{2} \text { para a } \\
\text { atmosfera; } \\
\text { Redução das áreas de } \\
\text { florestas, que absorvem e } \\
\text { estocam o carbono } \\
\text { atmosférico, }\end{array}$ \\
\hline $\mathrm{CH}_{4}$ (Metano) & $21 \times \mathrm{CO}_{2} \mathrm{e}$ & $\begin{array}{l}\text { Degradação anaeróbia de } \\
\text { material orgânico em aterros, } \\
\text { estações de tratamento de } \\
\text { efluentes, lagoas anaeróbias } \\
\text { com dejetos animais, além do } \\
\text { processo digestivo de animais } \\
\text { ruminantes (ex: gado } \\
\text { bovino).Rizicultura. }\end{array}$ \\
\hline $\mathrm{N}_{\mathrm{x}} \mathrm{O}$ (Oxido de nitrogênio) & $310 \times \mathrm{CO}_{2} \mathrm{e}$ & $\begin{array}{l}\text { Queima de } \\
\text { fósseis, uso abusivo e } \\
\text { incorreto de fertilizantes } \\
\text { químicos no solo. }\end{array}$ \\
\hline CFCs, HFCs, PFCs & $140 \times$ até $11.700 \times \mathrm{CO}_{2} \mathrm{e}$ & $\begin{array}{l}\text { Sistemas de refrigeração e } \\
\text { sprays aerossóis. }\end{array}$ \\
\hline $\mathrm{SF}_{6}$ (Hexafluoreto de enxofre) & $22.500 \times \mathrm{CO}_{2} \mathrm{e}$ & $\begin{array}{l}\text { Produzido industrialmente } \\
\text { para uso principalmente pela } \\
\text { indústria elétrica, como meio } \\
\text { isolante e extintor de arco } \\
\text { elétrico, tanto em disjuntores, } \\
\text { como em subestações } \\
\text { blindadas. }\end{array}$ \\
\hline
\end{tabular}

Fonte: IPCC 2007.

Em outro estudo, a British Royal Society utilizou as emissões de $\mathrm{CO}_{2}$ como medida de consumo de energia, demonstrando que os lançamentos per capita são até 50 vezes mais elevados nos países ricos do que nos pobres. O déficit de energia é considerado um dos principais componentes da pobreza. 
(GRENDELLE, 2012). A tabela 2 apresenta relação de valores de emissões por t/CO $\mathrm{CO}_{2}$ abrangendo vários parâmetros diferentes.

Tabela 2 - Indicadores de emissão de $\mathrm{t} / \mathrm{CO}_{2}$.

\begin{tabular}{|c|c|c|c|c|c|c|}
\hline indterdor & Brass & ENA & बाp20 & America Latine & Mundo & OCDE \\
\hline $\mathrm{tCO}_{2} / \mathrm{hab}$ & 1,90 & 18,38 & 9,02 & 2,31 & 4,39 & 10,61 \\
\hline tCO/ tep OlE & 1,47 & 2,45 & 2,32 & 1,86 & 2,40 & 2,33 \\
\hline$t C C_{2} / 103$ US\$ de PIB1 & 0,43 & 0,48 & 0,22 & 0,52 & 0,73 & 0,41 \\
\hline$t C 0,1 \mathrm{~km}^{2}$ de superficie & 43 & 598 & 3.047 & 51 & 142 & N.D. \\
\hline
\end{tabular}

\section{Nota: USS em valores correntes de 2000 \\ Fonte: Agència Inerenacional de Energia (IEA)}

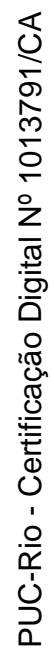

Fonte: BEN ${ }^{4}, 2011$.

Com o desmatamento e a queima de combustíveis fósseis cada vez mais intensos, a concentração desses gases está aumentando, especialmente as de $\mathrm{CO}_{2} \mathrm{e}$ Metano. Desde 1800, o Dióxido de carbono na atmosfera cresceu 30\%, enquanto o Metano aumentou $130 \%$.

A figura 7 demonstra a redução das emissões de $\mathrm{CO}_{2}$ do Brasil nos últimos anos.

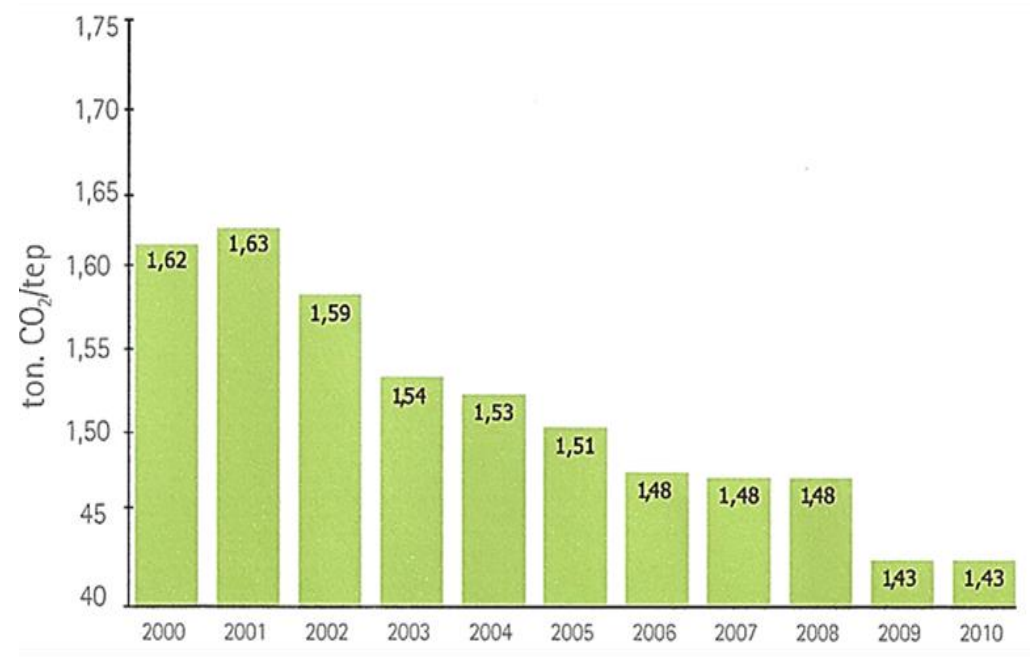

Figura 7 - Série Histórica de emissões de $\mathrm{CO}_{2}$ BRASIL. Fonte BEN 2011.

\footnotetext{
${ }^{4}$ BEN-Balanço Energético nacional.
} 
A figura 8 mostra a comparação entre o Brasil e os maiores emissores de gases responsáveis pelo aumento do efeito estufa. São os seguintes: os Estados Unidos, a União Europeia, a China, a Rússia, o Japão e a Índia. Os Estados Unidos - responsáveis por cerca de $36 \%$ do total mundial - lideram as emissões tanto em termos absolutos como per capita. (BEN, 2011).

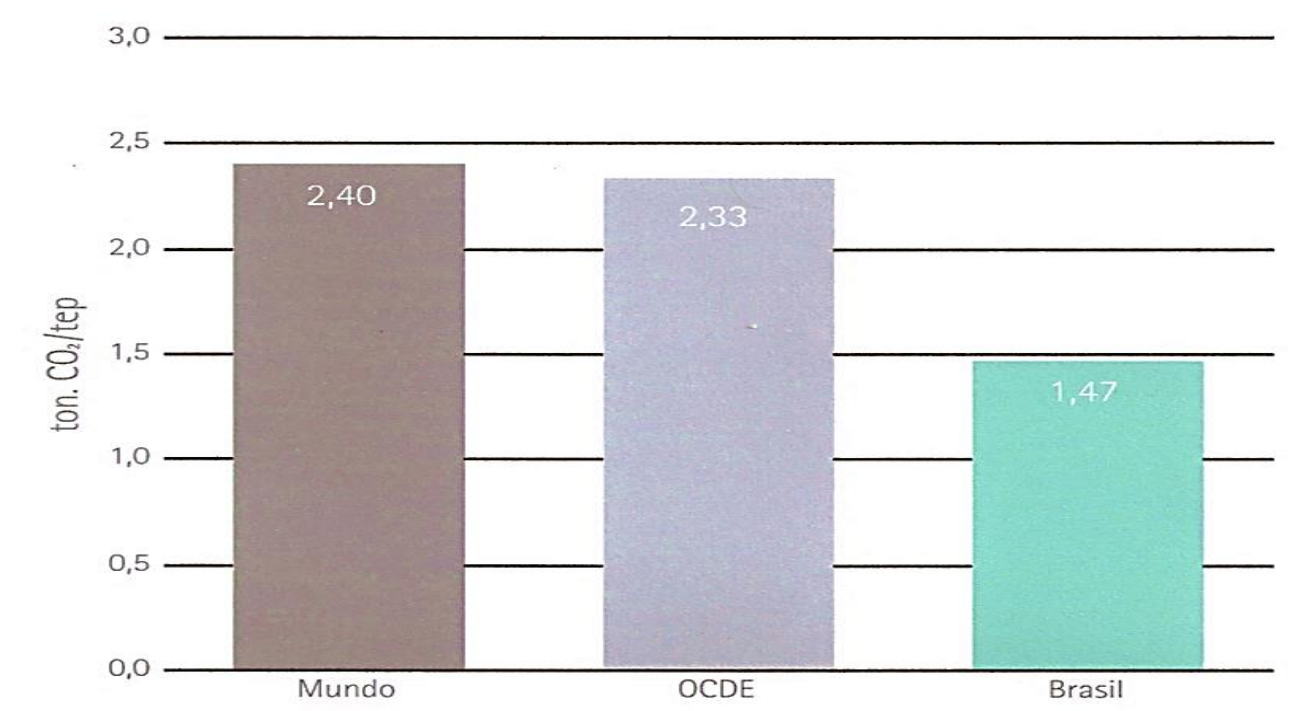

Figura 8 - Comparação internacional entre os maiores emissores. Fonte: BEN.(2011). OCDE( Organização do Comércio e Desenvolvimento Econômico)

\section{5 .2}

\section{Estimativas de emissões de $\mathrm{CO}_{2}$ por veículos automotores}

A queima de combustíveis gera essencialmente $\mathrm{CO}_{2}$ pela oxidação do carbono neles contido, liberando energia. Mas também produz $\mathrm{CH}, \mathrm{CO}$, e, como efeito secundário, $\mathrm{N}_{2} \mathrm{O}$ e NOx, NMVOC.( Não metano voláteis oxidados carbono)

As emissões de $\mathrm{CO}_{2}$ podem ser estimadas por duas metodologias do IPCC (Intergovernammental Panel on Climate Change, 1997): a abordagem de referência ou Top-Down, na qual as emissões são calculadas a partir da oferta de combustível; e a abordagem setorial ou Bottom-Up, na qual são calculadas a partir do consumo final energético em cada setor. Ambas desprezam a emissão de $\mathrm{CO}_{2}$ resultante da queima de biomassa, considerando apenas o produto de combustíveis fósseis. No Brasil, as estimativas baseiam-se nos dados de produção e consumo por fonte energética, obtidos do Balanço Energético Nacional (BEN) publicado anualmente pelo Ministério de Minas e Energia. (MME, 2010). 


\section{Metodologia Top-Down}

Pela metodologia Top-down do IPCC obtém-se um quadro geral das emissões de $\mathrm{CO}_{2}$ por queima de combustíveis fósseis no território de um país e seu reflexo no efeito estufa causado pelas atividades humanas (atividades antrópicas).

O enfoque dado aos combustíveis de biomassa não renováveis é outro. De acordo com a metodologia do IPCC, apuram-se, no setor de "Mudança do Uso da Terra e Florestas", as emissões pela conversão de florestas para outros usos. Nesse caso, são contabilizadas, porém não no setor energético.

Uma fração da ordem de $1 \%$ dos combustíveis de biomassa não é oxidada e acaba se incorporando ao solo. No caso do uso não energético dos combustíveis, considera-se, também que uma fração é retida no horizonte de tempo considerado (da ordem de um século).

A figura 9 exemplifica de modo esquemático a vantagem do método TopDown sobre outros métodos, que é a de não depender de informações detalhadas de como o combustível é utilizado pelo usuário final, ou sobre as transformações intermediárias dos combustíveis.

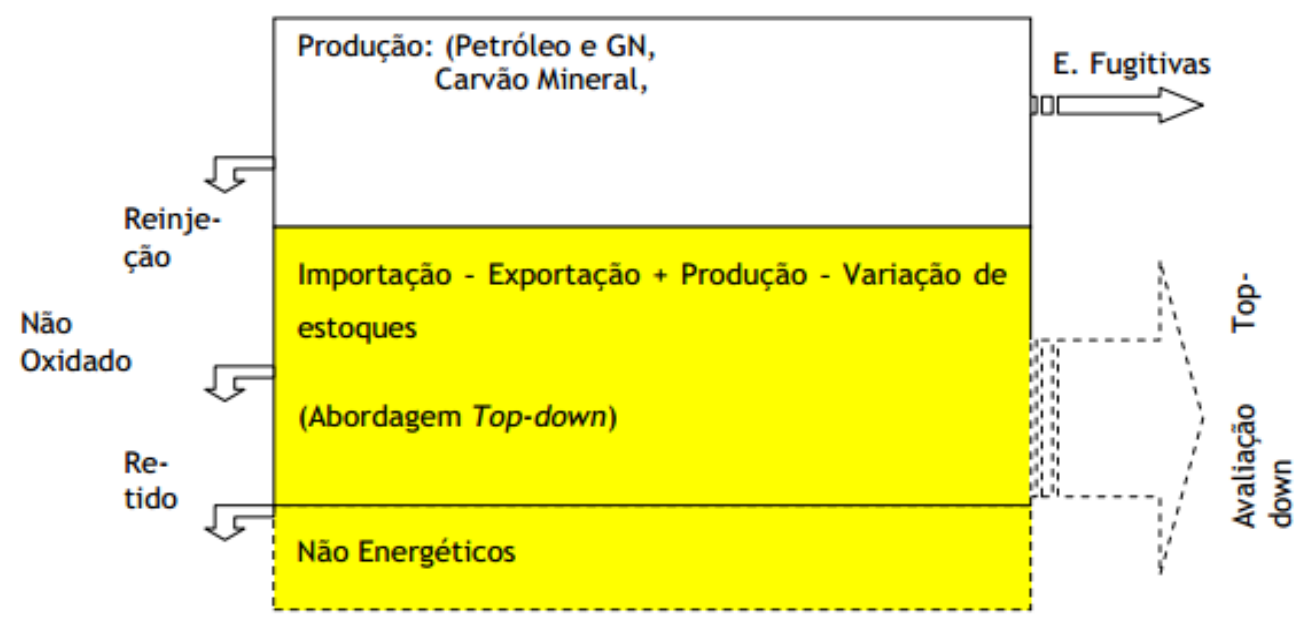

Figura 9 - Esquematização da metodologia Top-down. Fonte: MCTI, 2010.

Por esta contabilidade relativamente simples de "Emissões $=$ Entradas Saídas" tem-se uma boa aproximação do carbono emitido no país. O resultado é multiplicado por 44/12 para se obter a massa de gás carbônico correspondente. 
Na abordagem Top-down, os energéticos são separados por estado físico do produto primário, como o petróleo, seus derivados e líquidos de gás natural (líquidos), carvão (sólidos) e gás natural (gasosos). (CETESB, 2010).

Como base de referência genérica, a metodologia do IPCC não cobre aspectos específicos dos sistemas energéticos de todos os países. Portanto, para a obtenção de resultados coerentes com a situação real de um dado país, torna-se necessário adaptá-la às suas características particulares.

\section{Metodologia Bottom-Up}

As emissões de $\mathrm{CO}_{2}$ são dependentes do conteúdo de carbono dos combustíveis fósseis, por nível de agregação alto, conforme proposto na metodologia Top-Down. Mesmo assim, a metodologia do IPCC (IPCC, 1997) recomenda que se estimem as emissões de $\mathrm{CO}_{2}$ em um nível mais desagregado, também adotado para estimar as emissões dos outros gases de efeito estufa.

A metodologia Bottom-Up requer o conhecimento dos usos finais das fontes energéticas, bem como das características dos equipamentos utilizados.

As emissões de escapamento da frota circulante num determinado ano, para cada poluente e modelo de veículo, são estimadas a partir da seguinte equação 1:

$$
E=F r \times I u \times F e .
$$

\section{Equação 1}

Em que:

- E é a taxa anual de emissão do poluente considerado (g/ano).

- Fe é o fator de emissão do poluente considerado, expresso em termos da massa de poluentes emitida por $\mathrm{Km}$ percorrido (grama de poluente/Km). É específico para o ano modelo de veículo considerado e depende do tipo de combustível utilizado.

- Fr é a frota circulante de veículos do ano modelo considerado (número de veículos).

- Iu é a intensidade de uso do veículo do ano modelo considerado, expressa em termos de quilometragem anual percorrida (Km/ano). Trata-se de 
uma variável que depende de um conjunto de fatores socioeconômicos que, são representados pela idade do veículo. (CETESB, 2010).

A figura 10 ilustra a sequência lógica adotada nos procedimentos para estimar as emissões. Conforme mostram a Equação 1 e a Figura 10, a elaboração do inventário de emissões veiculares depende de três grandes conjuntos de dados: a frota de veículos em circulação, os fatores de emissão de poluentes e a intensidade de uso. (CETESB, 2010).

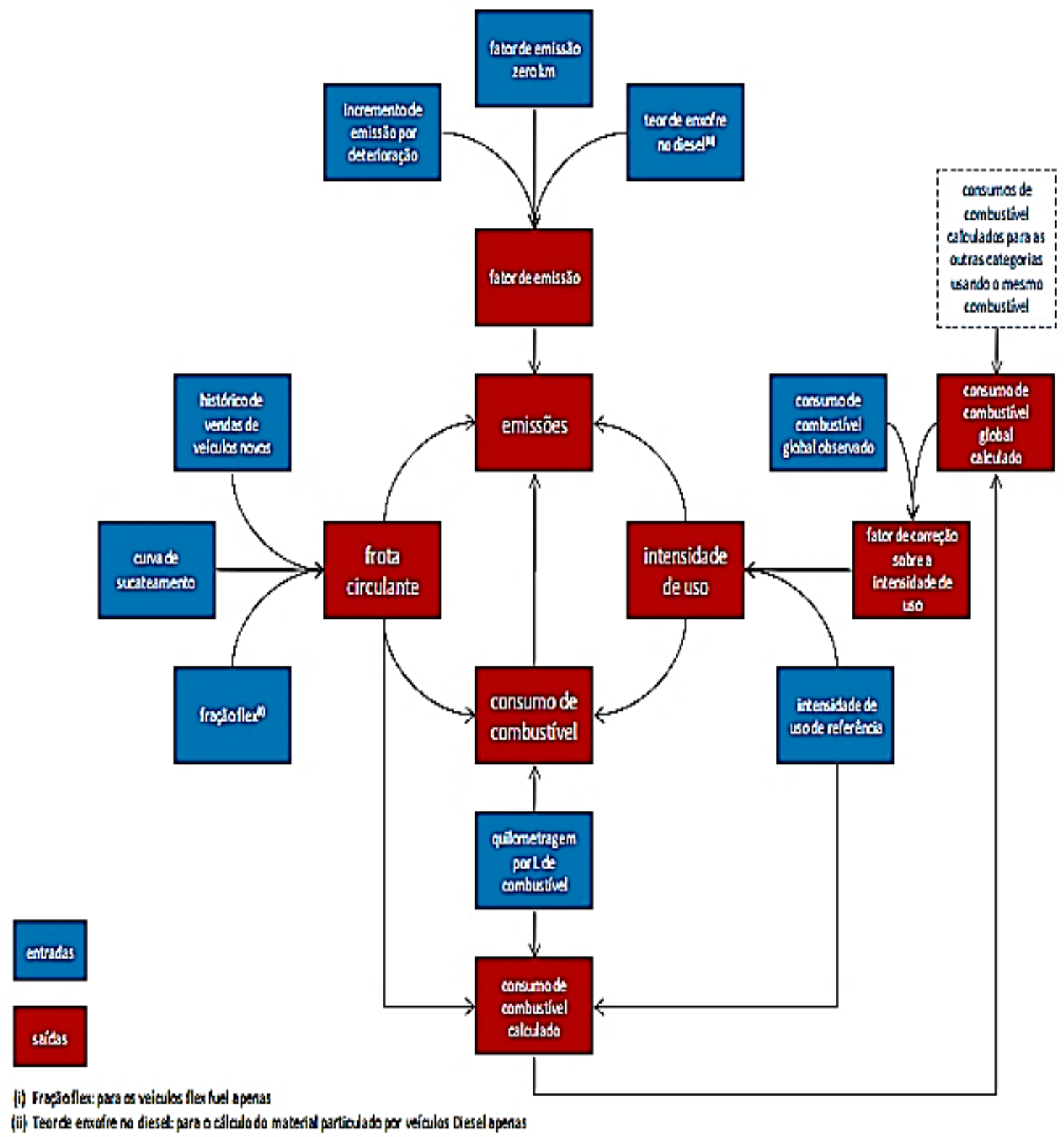

Figura 10 - Procedimentos adotados para estimar as emissões. Fonte: CETESB, 2010. 


\section{Escolha de método}

As emissões podem ser estimadas a partir de qualquer combustível consumido (representado por combustível vendido) ou a distância percorrida pelos veículos. Em geral, a primeira abordagem (combustível vendido) é apropriada para o $\mathrm{CO}_{2}$ e a segunda (distância percorrida pelo veículo e tipo de estrada) é apropriado para $\mathrm{CH}_{4}$ e $\mathrm{N}_{2} \mathrm{O}$. (IPCC, 2006).

\subsection{3}

\section{Emissões de outros gases de efeito estufa por queima de combustíveis}

Outros gases de efeito estufa são $\mathrm{CH}_{4}, \mathrm{NO}, \mathrm{CO}$ e NMVOC. São tratados de forma genérica como gases "não- $\mathrm{CO}_{2}$ " e suas emissões podem ser estimadas para todos os combustíveis, inclusive os derivados de biomassa.

\section{6}

\section{Poluição sonora e a coleta de RSU}

Um estudo de Quadros (2004), aponta que a poluição sonora é, depois da poluição do ar e da água, o problema ambiental que afeta o maior número de pessoas.

De acordo com a Organização Mundial de Saúde (OMS), um ruído de até $50 \mathrm{~dB}$ (A) (cinquenta decibéis) pode perturbar, mas o organismo se adapta facilmente a ele. A partir de $55 \mathrm{~dB}$ (A) (cinquenta e cinco decibéis) pode haver a ocorrência de estresse leve, acompanhado de desconforto. O nível de $70 \mathrm{~dB}$ (A) (setenta decibéis) é tido como o nível do desgaste do organismo, aumentando o risco de infarto, derrame cerebral, infecções, hipertensão arterial e outras patologias. A 80 dB (A) (oitenta decibéis) ocorre à liberação de endorfinas, causando uma sensação de prazer momentâneo. Já a 100 dB (A) (cem decibéis), pode haver perda da audição.

Segundo Zannin (2002), o relaxamento e o descanso sofrem em especial em condições de exposição ao ruído. Níveis de pressão sonora da ordem de $30 \mathrm{~dB}$ (A) podem ser tomados já como inoportunos e incomodativos. E, para buscar o 
equilíbrio frente aos distúrbios resultantes, seria necessário sono profundo associado a um longo período de descanso (MASCHKE, 1999). Mas, justamente aqui, encontra-se outro grave problema, na coleta do lixo urbano, que, ao contrário do ruído industrial, aparece também no período noturno. A figura 11 a seguir mostra as várias fontes de ruídos produzidos pelos caminhões que fazem esta coleta: na frente, no meio e na parte traseira. São: o funcionamento do motor, o escapamento, o ventilador, o sistema de admissão, a transmissão, o freio estacionário, pneus e o equipamento de coleta propriamente dito.

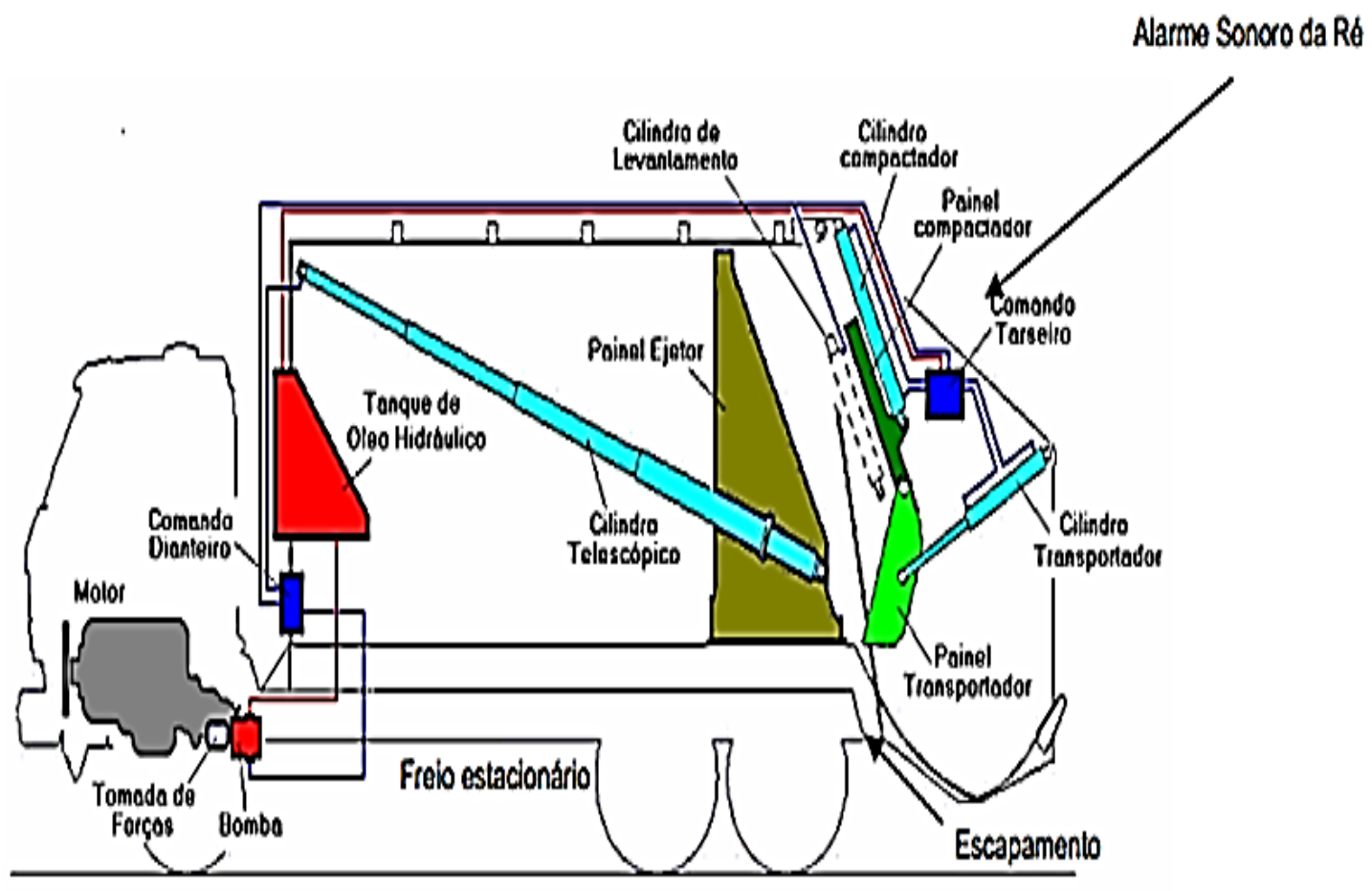

Figura 11 - Fontes de ruído veicular. Fonte: USIMECA, 2002.

O ruído gerado por veículos de utilidade pública, como o de coleta de resíduos domiciliares, tende a causar incômodo à comunidade. Zannin (2002) considera que o conhecimento atual das pesquisas sobre a influência do ruído não permite ainda uma afirmação sobre a dimensão dos riscos à saúde. No entanto, pode-se tomar como concreto que distúrbios duradouros devido ao ruído causam danos à saúde. Na tabela 3 são mostrados os níveis de potência sonora dos veículos utilizados na limpeza urbana. 
Tabela 3 - Níveis de potência sonora.

\begin{tabular}{|c|c|c|c|}
\hline Tipo de veículo & \begin{tabular}{|c|} 
Nivel de emissões \\
sonoras ${ }_{\text {waA }}$ \\
conforme DIN 45648 \\
em dB(A) de equip. \\
tradicionais.
\end{tabular} & $\begin{array}{c}\text { Exigências } \\
\text { conforme } \\
\text { RAL - UZ59 }\end{array}$ & $\begin{array}{l}\text { Providências para a } \\
\text { redução de ruídos. }\end{array}$ \\
\hline $\begin{array}{ll}\text { Veículo } & \text { de } \\
\text { sucção } & \\
\text { (aspiração) } & \end{array}$ & $91-115$ & 97 & $\begin{array}{l}\text { Blindagem total sobre } \\
\text { o motor e a bomba } \\
\text { auxiliares. Aplicação } \\
\text { de bomba de } \\
\text { circulação de água. }\end{array}$ \\
\hline $\begin{array}{l}\text { Veículos } \\
\text { combinados de } \\
\text { sucção/ lavagem } \\
\text { com alta pressão }\end{array}$ & $92-112$ & 99 & $\begin{array}{l}\text { As mesmas } \\
\text { providências } \\
\text { mencionadas acima. }\end{array}$ \\
\hline $\begin{array}{l}\text { Veículo de } \\
\text { lavagem com alta } \\
\text { pressão }\end{array}$ & $100-110$ & 97 & $\begin{array}{l}\text { Elevada potência do } \\
\text { motor } \\
\text { correspondentes } \\
\text { baixas rotações } \\
\begin{array}{l}\text { Providência } \\
\text { blindagem. }\end{array} \\
\end{array}$ \\
\hline $\begin{array}{ll}\text { Veículos } & \text { com } \\
\text { vassouras } & \\
\text { mecânicas } & \end{array}$ & $02-114$ & 99 & $\begin{array}{lr}\text { Melhor regulagem } \\
\text { (sincronização) } & \text { dos } \\
\text { sopradores. } & \\
\text { Providências } & \text { de } \\
\text { blindagem } & \text { nos } \\
\text { sopradores } & \\
\text { (ventiladores). } & \\
\end{array}$ \\
\hline $\begin{array}{l}\text { Veículos de } \\
\text { coleta de lixo }\end{array}$ & $105-115 \mathrm{~dB}(\mathrm{~A})^{*}$ & $\begin{array}{c}99 \text { e } \\
\text { acréscimo } \\
\text { de impulso } \\
<3 \mathrm{~dB}(\mathrm{~A})\end{array}$ & $\begin{array}{l}\text { Eliminação de golpes } \\
\text { (amortecedores de } \\
\text { borracha). Redução } \\
\text { da rotação do motor, } \\
\text { absorção do som. }\end{array}$ \\
\hline $\begin{array}{l}\text { Veículos } \\
\text { serviços } \\
\text { inverno. }\end{array}$ & $\begin{array}{l}102-118 \mathrm{~dB}(\mathrm{~A}) \text { com } \\
\text { acentuados efeitos } \\
\text { sonoros e de } \\
\text { impulsos (até o } \\
\text { momento não há } \\
\text { especificações, } \\
\text { limites de medição) }\end{array}$ & & $\begin{array}{l}\text { Providências } \\
\text { transmissões nas } \\
\text { veículo suporte) bem } \\
\text { como na hidráulica, no } \\
\text { arado e na fresa de } \\
\text { neve. }\end{array}$ \\
\hline
\end{tabular}

* Devido à acentuada presença de impulsos, com avaliação de impulsos.

Fonte:Quadros, 2004.

\section{7}

\section{Impacto ambiental}

Segundo a Norma ISO 14.001, impacto ambiental é qualquer modificação do meio ambiente, adversa ou benéfica, que resulte, no todo ou em parte, das atividades, produtos ou serviços de uma organização. Juridicamente, o conceito de impacto ambiental refere-se exclusivamente aos efeitos da ação humana sobre o meio ambiente. Portanto, fenômenos naturais como tempestades, enchentes, incêndios florestais por causa natural, terremotos e outros, apesar de provocarem 
as alterações ressaltadas, não motivam são se computam no impacto ambiental. (CIMM, Centro de Informação Metal Mecânica, 2013).

\subsection{1}

\section{Impactos ambientais de um aterro sem a preparação adequada}

Nos aterros sanitários, os problemas ambientais devem ser objeto de especial atenção voltada para a redução do impacto negativo decorrente da disposição de resíduos, principalmente para os riscos de contaminação do solo, das águas e do ar. (ENSINAS, 2003).

Os determinantes primários de impacto de qualidade do ar são a quantidade de biogás emitida, a concentração de compostos gasosos, a proximidade do receptor do aterro e as condições meteorológicas. (BANCO MUNDIAL, 2004).

Estima-se que um projeto de instalações de produção de energia do biogás preveja o aproveitamento de 60 a $80 \%$ do Metano emitido. O gás capturado, quando queimado, é convertido para água e $\mathrm{CO}$ (Monóxido de carbono), que é um gás muito menos potente.

A maioria dos aterros utiliza o sistema de drenos abertos, onde é mantida acesa uma chama para queima imediata do biogás que vai sendo naturalmente drenado. Esse sistema apresenta uma baixa eficiência e estima-se que apenas $20 \%$ do biogás drenado seja efetivamente queimado. O restante vai para a atmosfera.

No Brasil, uma grande parcela dos RSU é simplesmente disposto no solo, seja em aterros sanitários, aterros controlados ou vazadouros a céu aberto, o que resulta em inúmeros impactos ambientais, além das emissões de GEE. Entre seus aspectos negativos, podem ser citados. (ICLEI, 2009):

- Poluição do solo - o risco de contaminação do lençol freático e cursos d'água nas proximidades dos locais de disposição final de lixo, nos lixões e aterros que não possuem adequada impermeabilização de base, através do chorume. (líquido de elevado potencial poluidor, de cor escura e de odor desagradável, resultado da decomposição da matéria orgânica). 
- O total desperdício dos recursos naturais e energéticos contidos nos materiais dispostos nos aterros e lixões.

- A ocupação de extensas áreas para servirem de aterros, cada vez mais escassas, especialmente nas grandes cidades e em regiões metropolitanas. Próximo dessas áreas, geralmente, ocorre inconvenientes como o constante tráfego de caminhões transportando lixo.

- A liberação de maus odores, mais intensos e constantes em vazadouros a céu aberto, por conta da presença do gás sulfídrico $\left(\mathrm{H}_{2} \mathrm{~S}\right)$ contido na mistura do biogás.

- Alguns elementos constituintes do biogás podem causar câncer e outras doenças, que atacam fígado, rins, pulmões e sistema nervoso central. $\mathrm{O}$ biogás não é tóxico, mas atua sobre o organismo humano diluindo o oxigênio e, como consequência, pode provocar a morte por asfixia. Como é muito estável não é solúvel em água (PECORA, 2006). É mais denso que o ar (relação de densidade de 0,55 ), e, por isso, fica próximo ao solo facilitando sua inalação. (PARCHEN, 1979).

- Por ser de fácil combustão, o biogás necessita ser continuamente drenado para evitar explosões e riscos de incêndios nesses locais.

Assim, o biogás produzido pelos aterros deve ser drenado, captado e aproveitado como fonte de energia para mitigação dos efeitos causados pelo seu lançamento na atmosfera, notadamente no que concerne ao efeito estufa e ao aquecimento global.

\subsection{2}

\section{Emissões de GEE no município do Rio de Janeiro, RJ}

Segundo a COPPE/UFRJ (2005), os setores que mais emitem GEE são: transportes e resíduos. A figura 18 indica que o uso de combustíveis no setor de 
transportes no RJ aumentou cerca de 11\% no período 1996-2005. Atingiu 2.041, 7 mil tep (tonelada equivalente de petróleo), representando uma emissão total de 5.578 $\mathrm{Gg} \mathrm{CO}_{2}$ eq em 2005. A figura 12 mostra também que o transporte rodoviário participa com $80 \%$ dessas emissões (4.391 $\mathrm{Gg} \mathrm{CO}_{2}$ eq.), subdivididos em veículos leves (68\% das emissões de GEE), e veículos pesados (32\%).

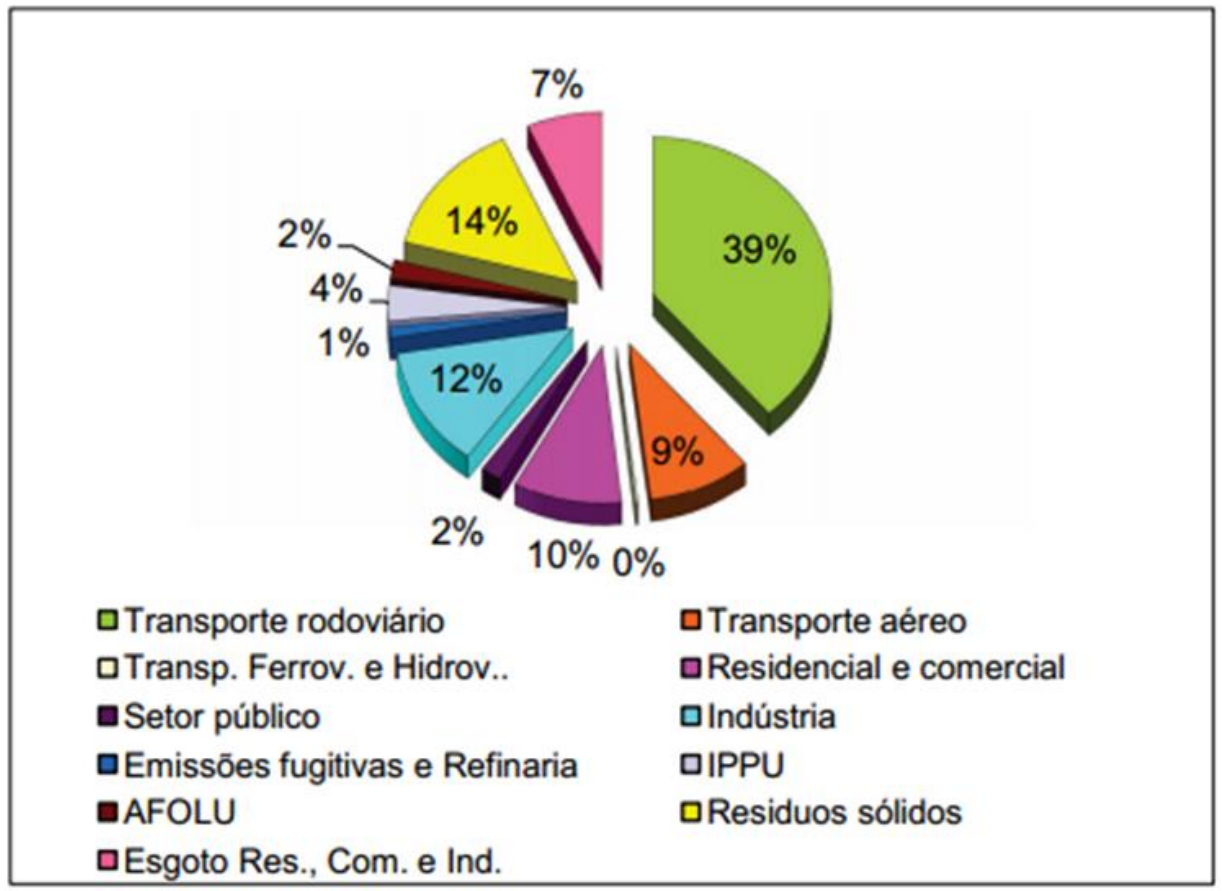

Figura 12 - Participação dos Setores na Emissão de GEE da Cidade do Rio de Janeiro, em 2005 ( $\mathrm{Gg} \mathrm{CO}_{2}$ eq). Fonte: COPPE/UFRJ.

Embora as emissões tenham variado somente 13\%, entre 1996 e 2005, verificou-se uma substituição dos energéticos, com a redução do consumo da gasolina e um aumento substancial no do gás natural veicular (GNV) que emite $20 \%$ a menos. Esse fato reflete a política adotada pelo governo estadual do Rio de Janeiro na época, para o incentivo ao uso do gás natural, com a redução do IPVA para aqueles veículos que o utilizassem como combustível. Somente mais recentemente, o avanço dos veículos flexfuel vem refletindo no aumento do consumo do álcool. 


\subsection{3}

\section{Emissões de GEE dos diferentes tipos de resíduos no RJ}

A emissão de GEE no Setor de Resíduos atingiu 2.372,5 $\mathrm{GgCO}_{2}$ eq. em 2005 , refletindo um aumento de 50,3 \% no período 1996-2005. No subsetor de RSU, esse incremento foi da ordem de $121 \%$, tanto relacionado ao consumo, quanto ao crescimento de população. A emissão per capita referente aos RSU saltou de 0,12 t CO 2 e/hab. em 1996 para 0,26 t $\mathrm{CO}_{2}$ eq./hab. em 2005. Resíduos industriais representam apenas uma pequena parcela de 0,2\% nas emissões de GEE do município.

Esgotos domésticos, comerciais e industriais emitem $\mathrm{CH}_{4}$ e $\mathrm{N}_{2} \mathrm{O}$ quando submetidos a tratamentos anaeróbios. No caso do esgoto doméstico, em 2005, representaram somente $6,8 \%$ das emissões municipais. A figura 13 apresenta um gráfico mostrando as alterações.

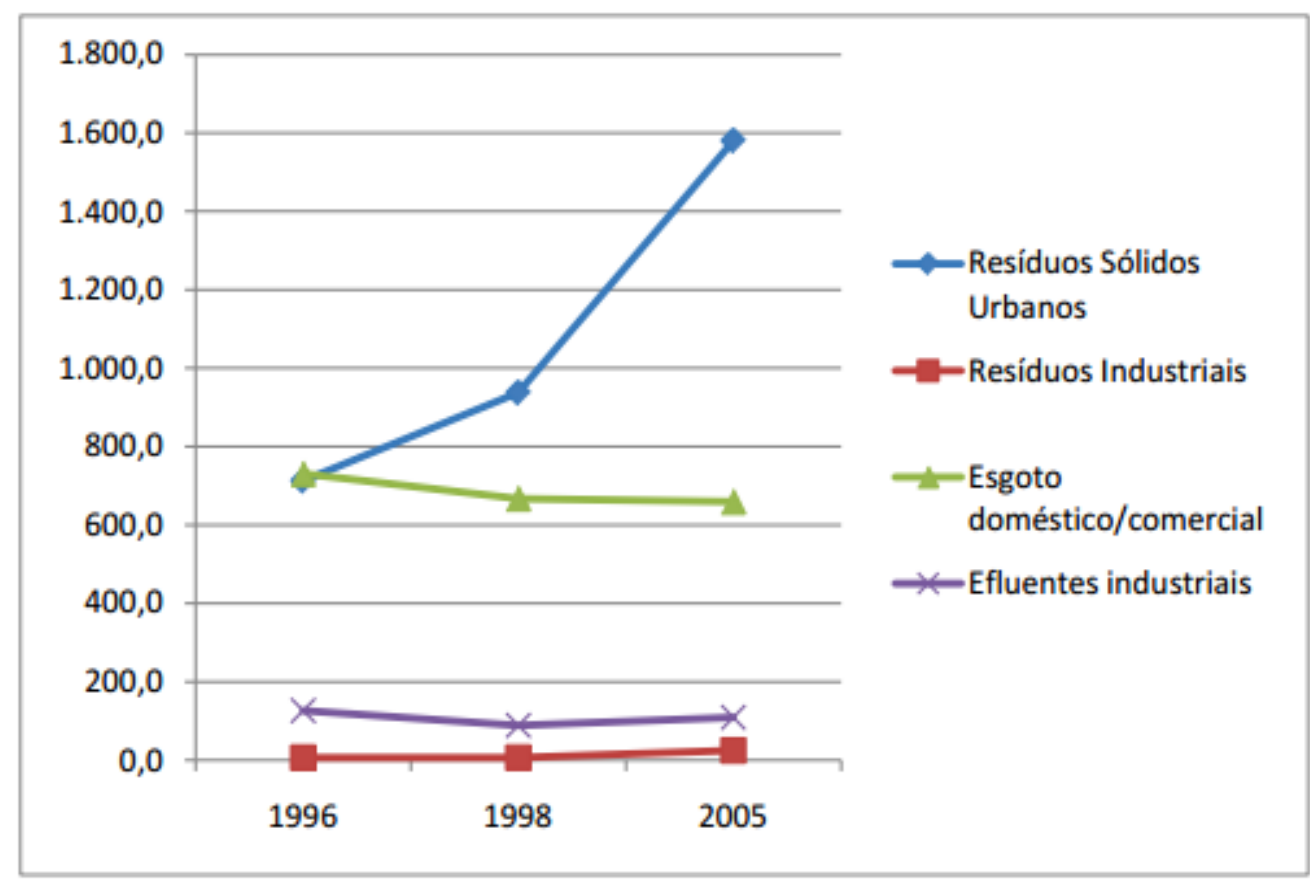

Figura 13 - Emissões de GEE no Setor de Resíduos ( $\mathrm{Gg} \mathrm{CO} \mathrm{CO}_{2}$ eq.). Fonte: COPPE/UFRJ. 


\subsection{4}

\section{Impactos ambientais e o ciclo de vida de um caminhão pesado}

Cabe avaliar, ao lado dos impactos ambientais decorrentes do aumento da geração de RSU, aqueles provenientes dos veículos que realizam a sua coleta. No Brasil, a frota de caminhões é, na sua maior parte, formada por veículos pesados movidos por combustíveis fósseis altamente poluidores. E também as implicações da sua substituição por veículos mais novos e energeticamente mais eficientes.

O processo de degradação ambiental, começa na fabricação desses veículos. Desde a extração da matéria-prima neles utilizada até o descarte, ao final de sua vida útil, detectam-se procedimentos de alto impacto não só na natureza, mas na saúde humana, pela emissão de gases de efeito estufa e o consumo de recursos naturais, água e energia.

Os veículos devem ser projetados e desenvolvidos a partir de diretrizes que não apenas privilegiem o consumo menor de combustível, como também auxiliem na redução de emissões de gases, utilizando materiais que causem menor dano.

Um estudo de Meyer (2001), aponta os pneus e as baterias, devido ao seu descarte difícil, como os itens que causam mais problema. Os pneus constituem os principais e mais numerosos resíduos sólidos provenientes da utilização dos veículos. Apesar de os pneus modernos durarem mais, o número de pneus descartados ainda é assustador. Por décadas esses pneus foram jogados em lixões e aterros sanitários, assim como em outros locais impróprios para tal finalidade. Devido à limitada capacidade desses destinos, têm se pesquisado outras alternativas para os pneus. Atualmente, há diferentes formas de aproveitamento desses pneus, como sua utilização na composição de borracha asfáltica, seu uso em barragens e até mesmo na construção de barreira de corais artificiais. Apesar de avanços tecnológicos na reciclagem de pneus já terem sido alcançados, economicamente ainda é difícil torná-la viável, pois seu custo ainda não foi internalizado.

Com relação a outros resíduos sólidos, pode-se afirmar que o chumbo (Ch), presente nas baterias, possui altos índices de reciclagem. As modernas baterias permitem seu eficiente reprocessamento. Ainda assim, o restante que não é reciclado causa impactos significativos ao meio ambiente. Aço e alumínio podem ser amplamente reciclados, porém sofrem degradação durante a 
reciclagem. A situação não é a mesma quando se trata de plásticos. Esses são difíceis e às vezes até impossíveis de serem reciclados, apesar de poderem ser incinerados com recuperação energética. Termoplásticos e outros materiais estão atingindo melhores índices de reciclagem, mas muito ainda precisa ser feito. Outra dificuldade da reciclagem dos plásticos ocorre devido à mistura de plásticos incompatíveis que torna a separação muito difícil e encarece o processo de reciclagem. É importante salientar que, apesar de materiais como o aço, por exemplo, apresentarem altos índices de reciclagem, uma parte muito pequena desse material reciclado é utilizada na produção de veículos. Uma explicação seria o fato de o aço reciclado ser impuro e não apresentar as propriedades necessárias para um componente automotivo. Já o alumínio pode ser reciclado e posteriormente ter o mesmo uso, como já ocorre com as latas de bebidas. Por isso, a participação de alumínio reciclado na produção de veículos aumenta significantemente se comparada com a do aço.

Deve-se ressaltar que não existe um método único de estudos da Análise do Ciclo de Vida (ACV) de um caminhão pesado. Porém, os tipos de energia nele utilizados variam de país para país ou até mesmo de cidade para cidade.

A figura 14 retrata o ciclo de vida de um caminhão pesado no Japão. 


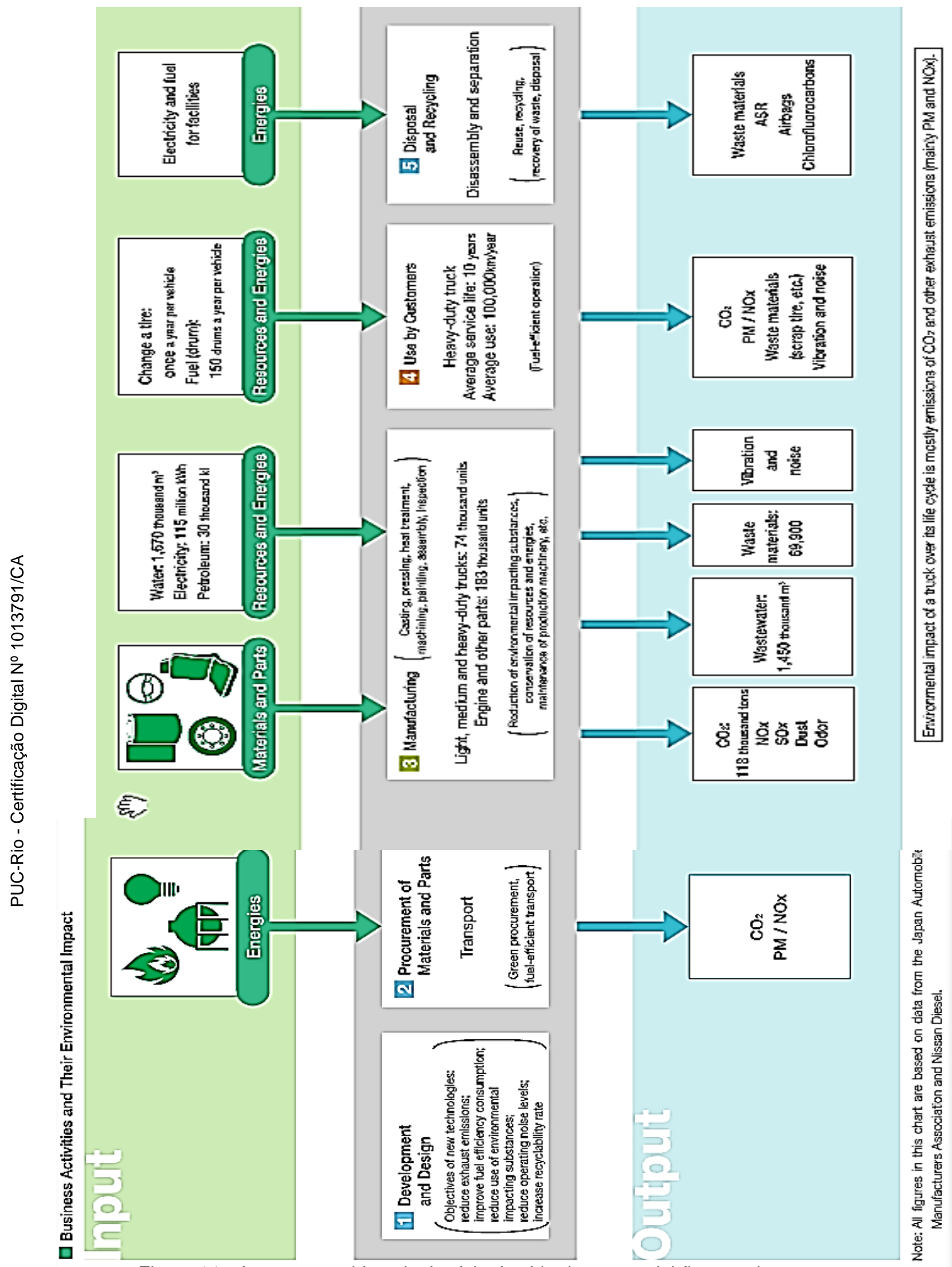

Figura 14 - Impactos ambientais do ciclo de vida de um caminhão pesado.

Fonte: Nissan (2008). 


\subsection{5}

\section{Ciclo de vida dos caminhões no Brasil}

Como pode ser observado na figura 15 , a idade média dos caminhões que rodam, hoje, nas estradas e ruas do Brasil é aproximadamente de 20 anos. São veículos que consomem mais combustíveis e produzem bastante poluição. Com relação à coleta de lixo, ainda existem vários municípios com frotas de caminhões, alguns com 15 anos de uso ou mais.

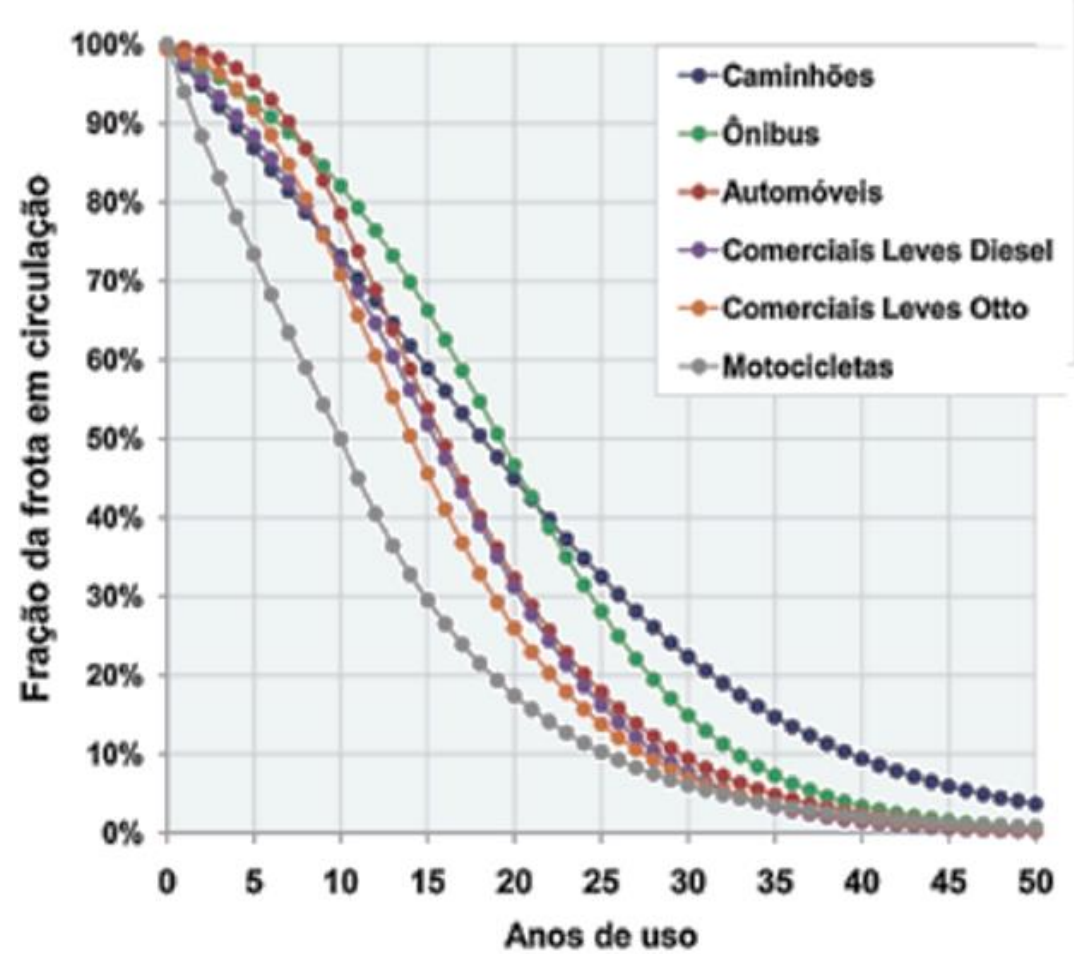

Figura 15 - Curva de sucateamento veículos no Brasil. Fonte: MMA (2009).

Segundo Barros (2013), na comparação com modelos feitos na década de 1970, os caminhões atuais estão cerca de $40 \%$ mais econômicos. Além disso, um caminhão moderno emite 50 vezes menos materiais particulados de enxofre que os veículos pesados de quatro décadas atrás. Com caminhões cada vez maiores, está sendo possível levar mais carga, aumentar a velocidade nos deslocamentos e reduzir o número de veículos em circulação. Em 1970, caminhões com 350 cv. estavam entre os mais potentes. Hoje, a média é de $450 \mathrm{cv}$, e há modelos de até $750 \mathrm{cv}$. 
A renovação mais ágil da frota traria outros benefícios. Os mais antigos, que continuam poluindo bastante, seriam descartados de forma programada, diminuindo a idade média da frota, com enorme ganho econômico e ambiental. No longo prazo, a tecnologia híbrida (motor à combustão e elétrico) poderá ser empregada e sua utilização, sendo incentivada, contribuirá, por certo, para a sua massificação. Os custos associados às novas tecnologias tenderão a cair nos próximos anos. 
3

\section{A LIMPEZA URBANA: CLASSIFICAÇÂO, COLETA E TRANSPORTE DOS RSU}

\section{1}

\section{Classificação}

Para a melhor eficácia da coleta, transporte, tratamento, aproveitamento e destinação final adequada do lixo é relevante conhecer a sua classificação.

Existem várias formas possíveis de classificar os resíduos sólidos:

- por sua origem

- por natureza física: seco e molhado.

- por sua composição química: matéria orgânica e inorgânica.

- pelos riscos potenciais ao meio ambiente: perigosos, não inertes e inertes

Carvalho (2005), no esquema retratado na figura 16 abaixo, propõe seguinte classificação para os resíduos sólidos:

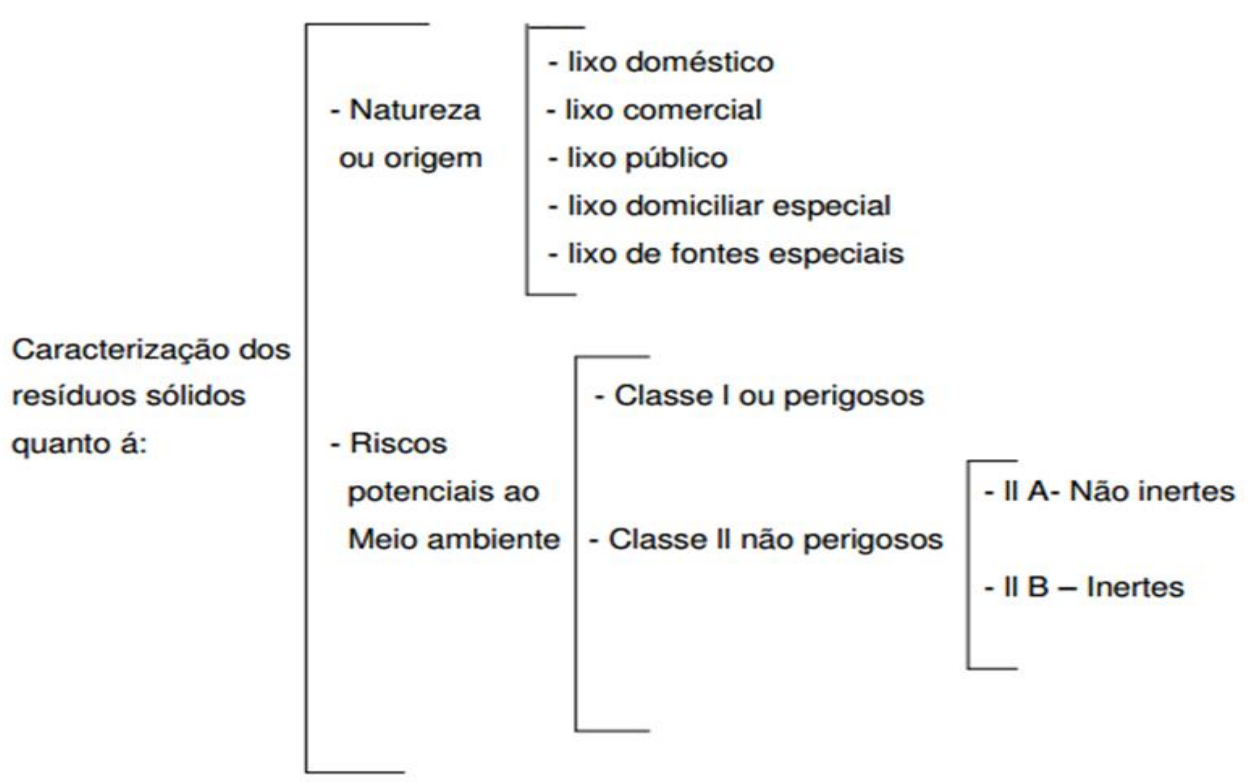

Figura 16 - Classificação para os resíduos sólidos. Fonte: Carvalho (2005). 
Quanto à sua natureza ou origem, conforme o Manual de Gerenciamento Integrado de Resíduos Sólidos (MONTEIRO, 2001), os resíduos distinguem-se em diversas categorias, a saber:

- Domiciliar: originado da vida diária das residências, constituído por restos de alimentos, produtos deteriorados, jornais e revistas, garrafas, embalagens em geral, papel higiênico, fraldas descartáveis e uma grande diversidade de outros itens. Contém ainda resíduos que podem ser tóxicos.

- Comercial: originado dos diversos estabelecimentos comerciais e de serviços, tais como, supermercados, estabelecimentos bancários, lojas, bares, restaurantes etc. $\mathrm{O}$ lixo destes estabelecimentos e serviços tem forte componente de papel, plásticos, embalagens diversas e resíduos de asseio dos funcionários, tais como, papel toalha, papel higiênico, etc. O grupo de lixo comercial, assim como os entulhos de obras, pode ser dividido em subgrupos chamados de pequenos geradores (até 120 litros de lixo por dia) e grandes geradores de resíduos (acima de 120 litros por dia).

- Público: originado dos serviços de limpeza pública urbana, inclui todos os resíduos da varrição das vias públicas, limpeza de praias, de galerias, de córregos e de terrenos, restos de poda de árvores, de feiras livres, corpos de animais etc.

Nas atividades de limpeza urbana, os tipos doméstico e comercial, constituem o chamado lixo domiciliar, que, junto com o lixo público, representa a maior parcela dos resíduos sólidos produzidos nas cidades. (RESOL, 2011).

Lixo domiciliar especial - compreende os entulhos de obras, pilhas e baterias, lâmpadas fluorescentes e seus reatores, e pneus. No Brasil, fabricantes, importadores, distribuidores e comerciantes, são obrigados, por lei, a cuidar do seu passivo ambiental, tendo que se organizar para colher e reaproveitar o material, e dar destinação final correta para as partes inservíveis. 
Entulho: resíduos da construção civil, como materiais de demolição e restos de obras, de escavações etc. O entulho é um material inerte, passível de reaproveitamento. Alguns de seus componentes podem the conferir toxicidade, como os restos de tintas e de solventes, peças de amianto e metais diversos. Segundo Monteiro (2001), o entulho corresponde a cerca de $50 \%$ da quantidade, em peso, de RSU coletados em cidades com mais de 500 mil habitantes.

A indústria da construção civil é a que mais explora recursos naturais e a que mais produz resíduos. No Brasil, a tecnologia construtiva normalmente aplicada favorece o desperdício nas obras realizadas. Em países desenvolvidos a média de resíduos proveniente de novas edificações se encontra abaixo de 100 $\mathrm{kg} / \mathrm{m}^{2}$, enquanto no Brasil esse índice gira em torno de $300 \mathrm{~kg} / \mathrm{m}^{2}$ edificados.

Em termos de composição, os resíduos da construção civil são uma mistura de materiais, como concreto, argamassa, madeira, plásticos, papelão, vidros, metais, cerâmica e terra. (PRICEWATERHOUSECOOPERS, 2010). No Brasil, existem em operação cerca de nove unidades de beneficiamento de resíduos de construção implantadas a partir de 1991, sendo a experiência mais significativa a da Prefeitura de Belo Horizonte, que dispõe de duas usinas de reciclagem de entulho, com capacidade para processar até 400 toneladas diárias.

O entulho reciclado pode ser usado como base e sub-base de rodovias, agregado graúdo na execução de estruturas de edifícios, e em peças pré-moldadas.

Um dos grandes problemas do entulho está relacionado ao seu acondicionamento, pois os contêineres metálicos utilizados atrapalham a passagem de pedestres e/ou o trânsito, bem como o estacionamento de veículos conforme se vê na figura 17. Além disso, o entulho de obra também consome muito espaço nos aterros, espaço esse que poderia ser utilizado para a destinação de outros tipos de resíduos não passíveis de reciclagem. (SELURB, 2010) 


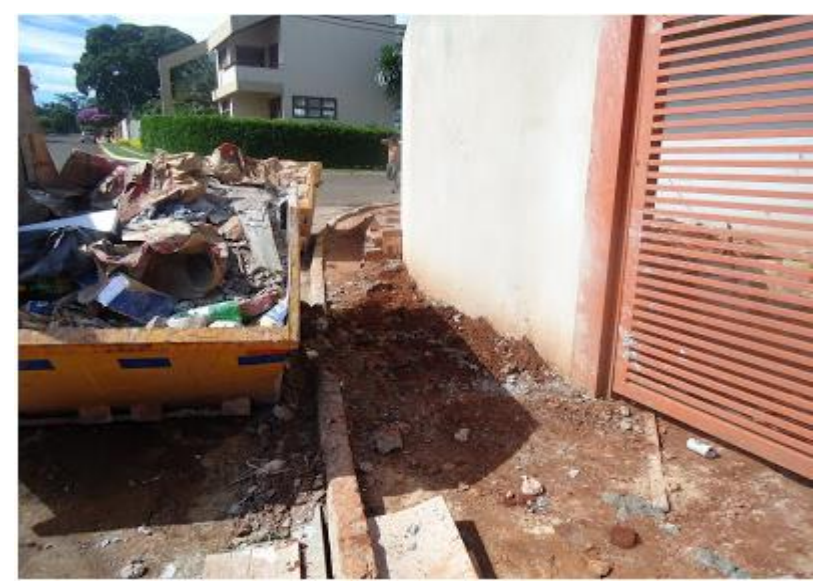

Figura 17 - Calçada sem possibilidade de circulação, com a obra não sinalizada, não possuindo uma rampa provisória para desvio pelo asfalto. Fonte: Blog Acessibilidadenaprática. (2011)

Outros resíduos específicos merecem ser citados, tanto pelo volume gerado como pelos numerosos impactos negativos no meio ambiente.

i. Pilhas e baterias - podem conter um ou mais dos seguintes metais: chumbo $(\mathrm{Pb})$, cádmio $(\mathrm{Cd})$, mercúrio $(\mathrm{Hg})$, níquel $(\mathrm{Ni})$, prata $(\mathrm{Ag})$, lítio (Li), zinco ( $\mathrm{Zn})$, manganês (Mn) e seus compostos. As pilhas que contêm esses metais possuem características de corrosividade, reatividade e toxicidade e são classificadas como "Resíduos Perigosos - Classe I". As substâncias contendo cádmio, chumbo, mercúrio, prata e níquel causam impactos negativos sobre o meio ambiente e, em especial, sobre o homem. Outras substâncias presentes nas pilhas e baterias, como o zinco, o manganês e o lítio, embora não estejam limitadas pela NBR 10004, também causam problemas ao meio ambiente. A reciclagem envolve o reaproveitamento do plástico das carcaças, do aço e dos óxidos metálicos, resultantes de processos químicos, que podem ser utilizados em indústrias de tintas e cerâmicas.

ii. Lâmpadas fluorescentes - o pó, encontrado no interior das lâmpadas fluorescentes, que se torna luminoso, contém mercúrio. Isso não se restringe apenas às comuns de forma tubular, mas também às compactas. As lâmpadas liberam mercúrio quando quebradas, queimadas ou 
enterradas em aterros sanitários. Classificam-se como resíduos perigosos Classe I, pois o mercúrio é tóxico nocivo ao sistema nervoso humano quando inalado ou ingerido. Lançado no meio ambiente, sofre uma bioacumulação, o que provoca sua concentração nos tecidos dos peixes. Esse acúmulo de mercúrio nos tecidos pode contaminar ainda espécies selvagens, como marrecos, aves aquáticas, entre outros animais. As lâmpadas fluorescentes também são passíveis de reciclagem. Pequenas quantidades de lâmpadas fluorescentes quebradas acidentalmente podem ser descartadas como lixo comum. Contudo, o destino adequado, quando em quantidades consideráveis, é o aterro Classe I.

iii. Pneus - Como mencionado anteriormente, são muitos os problemas ambientais gerados pela destinação inadequada dos pneus. Deixados em ambiente aberto, sujeito às chuvas, acumulam água, e permitem a proliferação de mosquitos. Quando encaminhados para aterros de lixo convencionais, provocam "vazios" na massa de resíduos, causando a instabilidade do aterro. Se destinados a unidades de incineração, a queima da borracha gera enormes quantidades de material particulado e gases tóxicos, necessitando de um sistema de tratamento dos gases extremamente eficiente e caro. Por todas estas razões, o descarte de pneus é hoje um problema ambiental grave, ainda sem uma solução realmente eficaz. Podem se transforma em solados, percintas usadas na estrutura de móveis estofados, asfalto, componente em tijolos de concreto e também como matéria-prima para produção de energia em cimenteiras, por exemplo. Recomenda-se como solução de destino final proceder à trituração dos pneus, dispondo-os em um aterro sanitário. (MONTEIRO, 2001).

iv. Lixo eletrônico (e-lixo): também conhecido como REEE (Resíduo de Equipamentos Eletro Eletrônicos) é todo resíduo material produzido pelo descarte de equipamentos eletrônicos. Com o elevado uso de equipamentos eletrônicos devido às constantes mudanças tecnológicas no mundo moderno, este tipo de lixo tem se tornado um grande problema ambiental quando não descartado em locais adequados. Alguns exemplos 
de lixo eletrônico: monitores de computador, telefones celulares, computadores, televisores, câmeras fotográficas, impressoras e muitos outros.

Como estes equipamentos possuem substâncias químicas (chumbo, cádmio, mercúrio, berílio etc.) altamente tóxicas, além de outros compostos químicos, podem gerar contaminação de solo e água e provocar doenças graves em pessoas que coletam produtos em lixões, terrenos baldios ou na rua. Estes equipamentos contêm grande quantidade de plástico, metais e vidro, materiais não passíveis de reaproveitamento.

A gestão e a reciclagem dos REEE é feita em etapas: coleta, desmontagem, pré-processamento e processamento. Depois de coletados, os REEE passam por um processo de manufatura reversa, no qual são desmontados e cada material é classificado. As substâncias tóxicas devem ser neutralizadas por meio de diversos processos físico-químicos. Os materiais que podem ser transformados em matéria-prima são encaminhados para reciclagem. Estão incluídos plásticos, ferro, alumínio, fios e cabos, entre outros. Partes de monitores, alguns tipos de baterias e lâmpadas de mercúrio, entre outros, podem apresentar dificuldades ou custos elevados para serem descontaminados. Nesse caso, estes subprodutos devem sofrer disposição adequada, ou seja, no aterro classe I.

Lixo de fontes especiais - resíduos que, em função de suas características peculiares, passam a merecer cuidados especiais em seu manuseio, acondicionamento, estocagem, transporte ou disposição final. Dentro da classe de resíduos de fontes especiais, merecem destaque:

- Portos, aeroportos, terminais rodoviários e ferroviários: constituem. resíduos sépticos. Basicamente são constituídos de materiais de higiene, asseio pessoal e restos de alimentos que podem veicular doenças provenientes de outras cidades, estados e países. Também nesse caso, os resíduos assépticos destes locais são considerados como domiciliares.

- Industrial: originado nas atividades dos diversos ramos da indústria, tais como metalurgia, química, petroquímica, alimentícia, etc. O lixo industrial 
é bastante variado, representado por cinzas, lodos, óleos, resíduos alcalinos ou ácidos, plástico, papel, madeira, fibra, borracha, metal, escórias, vidros ou cerâmicas. Nesta categoria inclui-se a grande maioria do lixo considerado tóxico.

- Agrícola: são os resíduos sólidos das atividades agrícolas e da pecuária. Incluem embalagens de fertilizantes e de defensivos agrícolas, ração, restos de colheita etc. Em várias regiões do mundo, estes resíduos já constituem uma preocupação crescente, destacando-se as enormes quantidades de esterco animal geradas nas fazendas de pecuária intensiva. Também as embalagens de agrotóxicos tem sido alvo de legislação específica, definindo os cuidados na sua destinação final e, por vezes, corresponsabilizando a própria indústria fabricante destes produtos.

- Serviços de saúde e hospitalar: constituem os resíduos sépticos, isto é, aqueles que hospitais, clínicas, laboratórios, farmácias, clínicas veterinárias, postos de saúde produzem. Trata-se de agulhas, seringas, gazes, bandagens, algodões, órgãos e tecidos removidos, meios de cultura e animais utilizados em testes, sangue coagulado, luvas descartáveis, remédios com prazos de validade vencidos, instrumentos de resina sintética, restos de medicamentos, filmes de raios $\mathrm{X}$, que misturados ao lixo doméstico poderão ser patógenos ou vetores de doenças, e devem ser destinados à incineração. Os resíduos de serviços de saúde classificam-se em infectantes, especiais e comuns. Segundo a NBR 12.808 da ABNT, os resíduos de serviços de saúde seguem a classificação apresentada na Tabela 4. 
Tabela 4 - Classificação dos resíduos de saúde.

\begin{tabular}{|c|c|c|}
\hline TIPO & NOME & CARACTERISTICAS \\
\hline \multicolumn{3}{|r|}{ CLASSE A - RESÍDUOS INFECTANTES } \\
\hline A.1 & Biol6gicos & $\begin{array}{l}\text { Cultura, inóculo, mistura de microorganismos e meio de cultura } \\
\text { inoculado provenientes de laboratório clínico ou de pesquisa, } \\
\text { vacina vencida ou inutilizada, filtro de gases aspirados de áreas } \\
\text { contaminadas por agentes infectantes e qualquer resíduo } \\
\text { contaminado por estes materiais. }\end{array}$ \\
\hline A.2 & $\begin{array}{c}\text { Sangue } \mathbf{e} \\
\text { hemoderivados }\end{array}$ & $\begin{array}{l}\text { Sangue e hemoderivados com prazo de validade vencido ou } \\
\text { sorologia positiva, bolsa de sangue para análise, soro, plasma e } \\
\text { outros subprodutos. }\end{array}$ \\
\hline A.3 & $\begin{array}{l}\text { Cirúrgicos, anato- } \\
\text { mopatologicos e } \\
\text { exsudato }\end{array}$ & $\begin{array}{l}\text { Tecido, órgão, feto, peça anatômica, sangue e outros líquidos } \\
\text { orgânicos resultantes de cirurgia, necropsia e resíduos } \\
\text { contaminados por estes materiais. }\end{array}$ \\
\hline A.4 & $\begin{array}{l}\text { Perfurantes e } \\
\text { cortantes }\end{array}$ & Agulha, ampola, pipeta, lâmina de bisturi e vidro. \\
\hline A.5 & $\begin{array}{l}\text { Animais } \\
\text { contaminados }\end{array}$ & $\begin{array}{l}\text { Carcaça ou parte de animal inoculado, exposto a microorganismos } \\
\text { patogênicos, ou portador de doença infecto-contagiosa, bem como } \\
\text { resíduos que tenham estado em contato com estes. }\end{array}$ \\
\hline A.6 & $\begin{array}{l}\text { Assistencia a } \\
\text { pacientes }\end{array}$ & $\begin{array}{l}\text { Secreções e demais líquidos orgânicos procedentes de pacientes, } \\
\text { bem como os resíduos contaminados por estes materiais, inclusive } \\
\text { restos de refeições. }\end{array}$ \\
\hline \multicolumn{3}{|r|}{ CLASSE B - RESÍDUOS ESPECIAIS } \\
\hline B.1 & Rejeitos radioativos & $\begin{array}{l}\text { Material radioativo ou contaminado com radionuclídeos, } \\
\text { proveniente de laboratório de análises clínicas, serviços de } \\
\text { medicina nuclear e radioterapia. }\end{array}$ \\
\hline B.2 & $\begin{array}{l}\text { Residuos } \\
\text { farmacêuticos }\end{array}$ & Medicamento vencido, contaminado, interditado ou não utilizado. \\
\hline B.3 & $\begin{array}{l}\text { Residuos } \\
\text { químicos perigosos }\end{array}$ & $\begin{array}{l}\text { Resíduo tóxico, corrosivo, inflamável, explosivo, reativo, genotóxico } \\
\text { ou mutagênico. }\end{array}$ \\
\hline \multicolumn{3}{|r|}{ CLASSE C - RESÍDUOS COMUNS } \\
\hline C & Resíduos comuns & $\begin{array}{l}\text { São aqueles que não se enquadram nos tipos A e B e que, por sua } \\
\text { semelhança aos resíduos domésticos, não oferecem risco adicional } \\
\text { à saúde pública. }\end{array}$ \\
\hline
\end{tabular}

Fonte: Monteiro, 2001.

- Resíduos radioativos: assim considerados os resíduos que emitem radiações acima dos limites permitidos pelas normas ambientais. No Brasil, o manuseio, o acondicionamento e a disposição final do lixo radioativo estão a cargo da Comissão Nacional de Energia Nuclear (CNEN).

A periculosidade vem tratada pela ABNT na norma NBR10004:2004 da seguinte forma:

Resíduos Perigosos (Classe I): são aqueles que por suas características podem apresentar riscos para a sociedade ou para o meio ambiente. São considerados perigosos também os que apresentem uma das seguintes características: inflamabilidade, corrosividade, reatividade, toxicidade e/ou patogenicidade. $\mathrm{Na}$ 
norma estão definidos os critérios que devem ser observados em ensaios de laboratório para a determinação destes itens. Os resíduos que recebem esta classificação requerem cuidados especiais de destinação.

Resíduos Não Perigosos (Classe II): não apresentam nenhuma das características acima. Possuem características de se decomporem com o tempo sem comprometer o meio ambiente e as pessoas em seu entorno. Podem ainda ser classificados em dois subtipos:

- Classe II A - não inertes: são aqueles que não se enquadram no item anterior, Classe I, nem no próximo item, Classe II B. Geralmente, apresentam alguma dessas características: biodegradabilidade, combustibilidade e solubilidade em água.

- Classe II B - inertes: quando submetidos ao contato com água destilada ou desionizada, à temperatura ambiente, não tiverem nenhum de seus constituintes solubilizados a concentrações superiores aos padrões de potabilidade da água, com exceção da cor, turbidez, dureza e sabor, conforme anexo $\mathrm{G}$ da norma NBR10004: 2004. Isto significa que a água permanecerá potável quando em contato com o resíduo. Muitos destes resíduos são recicláveis. Não se degradam ou não se decompõem quando dispostos no solo (se degradam muito lentamente). Estão nesta classificação, por exemplo, os entulhos de demolição, pedras e areias retiradas de escavações.

De acordo com Monteiro (2001), as características do lixo podem variar em função de aspectos sociais, econômicos, culturais, geográficos e climáticos, ou seja, os mesmos fatores que também diferenciam as comunidades entre si e as próprias cidades.

A Tabela 5 expressa a variação das composições do lixo em alguns países, e mostra que a participação da matéria orgânica tende a diminuir nos países mais desenvolvidos ou industrializados. 
Tabela 5 - Composição gravimétrica do lixo de alguns países (\%).

\begin{tabular}{l|r|r|r|r}
\multicolumn{1}{c|}{ COMPOSTO } & BRASIL & ALEMANHA & HOLANDA & EUA \\
Mat. orgânica & 65,00 & 61,20 & 50,30 & 35,60 \\
Vidro & 3,00 & 10,40 & 14,50 & 8,20 \\
Metal & 4,00 & 3,80 & 6,70 & 8,70 \\
Plástico & 3,00 & 5,80 & 6,00 & 6,50 \\
Papel & 25,00 & 18,80 & 22,50 & 41,00 \\
\hline
\end{tabular}

Fonte: Monteiro, 2001.

\section{2}

\section{Características dos RSU}

\subsection{1}

\section{Características físicas}

De acordo com a NBR 10.004 da ABNT, os resíduos sólidos podem ainda ser caracterizados considerando :

- Geração per capita

- Composição gravimétrica

- Peso específico aparente

- Teor de umidade

- Compressividade

\subsection{2}

\section{Geração per capita}

A "geração per capita" relaciona a quantidade de resíduos urbanos gerada diariamente e o número de habitantes de determinada região. Muitos técnicos consideram de 0,5 a $0,8 \mathrm{~kg} / \mathrm{hab}$./dia como a faixa de variação média para o Brasil.

A produção de resíduos sólidos domiciliares de uma cidade está relacionada com sua condição socioeconômica. As cidades com renda per capita maior produzem mais lixo que cidades com população semelhante e renda per 
capita menor. Outras variáveis, como clima e costumes, também podem alterar a quantidade de lixo.

Para obter um valor correto da produção de resíduos de um município, deve-se utilizar a pesagem diária dos caminhões da coleta, em balanças tipo rodoviárias.

O critério indicado para a execução dessa pesagem é de 7 (sete) dias corridos, de segunda a segunda. Em municípios com atividades sazonais, como por exemplo, no verão e no inverno, a pesagem deve ser efetuada na época considerada comum e em períodos de temporada.

Quando não houver possibilidade da pesagem e existindo a necessidade de estimar a quantidade de lixo originado nos domicílios, considera-se a produção de lixo por número de habitante. A figura 18 mostra a relação per capita entre a produção domiciliar de resíduos e o número de habitantes.

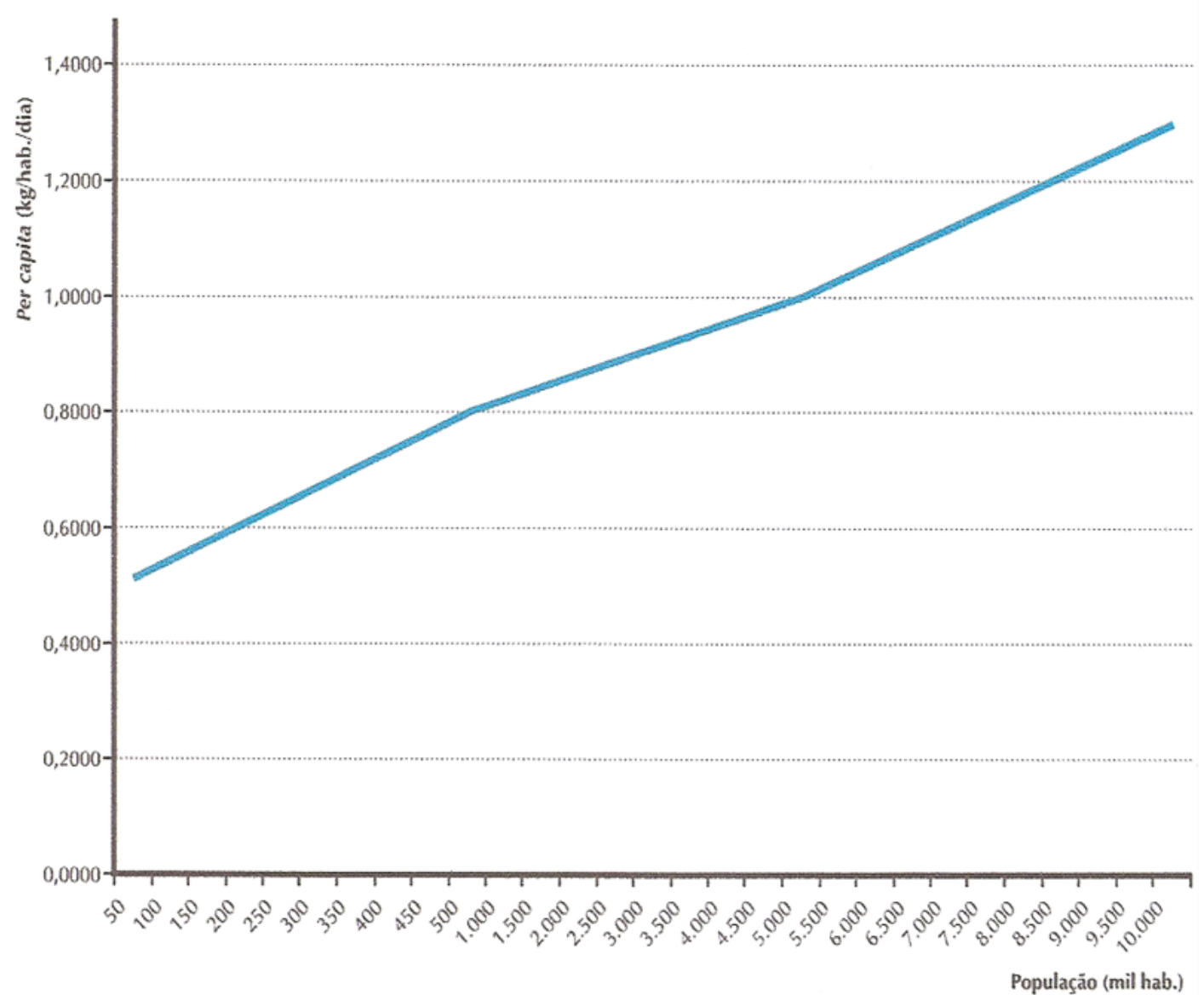

Figura 18 - Relação per capita entre a produção domiciliar de resíduos e o número de habitantes. 
Conhecer a geração per capita é fundamental para calcular as quantidades de resíduos a coletar e a dispor, e auxilia no dimensionamento dos veículos de coleta e de todas as unidades que compõem o Sistema de Limpeza Urbana. É ainda elemento básico para a determinação da taxa de coleta.

\subsection{3}

\section{Composição gravimétrica}

A composição gravimétrica traduz o percentual de cada componente em relação ao peso total da amostra de lixo analisada. Os componentes mais utilizados na determinação da composição gravimétrica dos RSU encontram-se na Tabela 6.

Tabela 6 - Componentes mais comuns da composição gravimétrica.

$\begin{array}{ccc}\text { Matéria orgânica } & \text { Metal ferroso } & \text { Borracha } \\ \text { Papel } & \text { Metal näo-ferroso } & \text { Couro } \\ \text { Papelão } & \text { Alumínio } & \text { Pano/trapos } \\ \text { Plástico rígido } & \text { Vidro claro } & \text { Ossos } \\ \text { Plástico maleável } & \text { Vidro escuro } & \text { Cerâmica } \\ \text { PET } & \text { Madeira } & \text { Agregado fino }\end{array}$

Fonte: Monteiro, 2001.

Entretanto, muitos técnicos tendem a simplificar, considerando apenas alguns componentes, tais como papel/papelão; plásticos; vidros; metais; matéria orgânica e outros. Esse tipo de composição simplificada pode ser usado no planejamento de uma usina de compostagem e de outras unidades de um sistema de limpeza urbana. Mas, segundo estudo preciso, não se presta à reciclagem ou à coleta seletiva, não se presta, por exemplo, já que o mercado de plásticos rígidos é bem diferente do mercado de plásticos maleáveis, assim como os mercados de ferrosos e não-ferrosos. 


\subsection{4}

\section{Peso específico}

Peso específico ou densidade aparente é o peso do lixo solto em função do volume ocupado livremente, sem qualquer compactação expressa em $\mathrm{Kg} / \mathrm{m}^{3}$.

Sua determinação é fundamental para a mensuração do serviço de coleta e a forma ideal de acondicionamento do material a ser removido. $\mathrm{Na}$ ausência de dados mais precisos, pode-se utilizar os valores de $230 \mathrm{Kg} / \mathrm{m}^{3}$ para o peso específico do lixo domiciliar, de $280 \mathrm{~kg} / \mathrm{m}^{3}$ para o peso específico dos resíduos de serviços de saúde e de $1.300 \mathrm{~kg} / \mathrm{m}^{3}$ para o peso específico de entulho de obras. É muito importante ainda para o correto dimensionamento da frota de coleta, assim como de contêineres e caçambas estacionárias.

Nas últimas décadas, o peso específico aparente tem decaído em consequência do teor de matéria orgânica encontrada no lixo e pelo aumento da quantidade de plástico e alumínio em uso.

Em qualquer cidade que disponha de controle do peso de lixo coletado, é possível verificar matematicamente se a coleta é, de fato, regular, comparando-se os pesos de lixo em duas ou mais semanas consecutivas. Nos mesmos dias da semana (uma segunda-feira comparada com outra segunda-feira, e assim por diante) os pesos de lixo não devem variar mais que $10 \%$. Da mesma forma, a quilometragem percorrida pelas viaturas de coleta deve ser semelhante, pois os itinerários a serem seguidos serão os mesmos (para um mesmo número de viagens ao destino). Além disso, a ocorrência de pontos de acumulação de lixo domiciliar nos logradouros e um número elevado de reclamações apontam claramente qualquer irregularidade da coleta.

\subsection{5}

\section{Teor de umidade}

Teor de umidade representa a quantidade de água presente no lixo, medida em percentual do seu peso. Este parâmetro altera em função das estações do ano e da incidência de chuvas, cabendo estimar um teor de umidade variando em torno de 40 a $60 \%$. 
Tem reflexo direto sobre a velocidade de degradação da matéria orgânica no processo de compostagem. Influencia, também, o poder calorífico e o peso específico aparente do lixo, concorrendo, de forma indireta, para a avaliação do número e tamanho de incineradores e usinas de compostagem.

Possibilita o cálculo da produção de chorume e a adequada projeção do sistema de coleta de percolados.

\subsection{6}

\section{Compressividade}

Compressividade é o grau de compactação ou a redução do volume que uma massa de lixo pode sofrer quando compactada. Submetido a uma pressão de $4 \mathrm{Kg} / \mathrm{cm}^{2}$, o volume do lixo pode ser reduzido de um terço (1/3) a um quarto (1/4).

Analogamente à compressão, a massa de lixo tende a se expandir quando é extinta a pressão que a compacta, sem, no entanto, voltar ao volume anterior. Esse fenômeno chama-se empolação e deve ser considerado nas operações com o lixo do aterro. Muito importante para o dimensionamento de veículos coletores, estações de transferência com compactação e caçambas compactadoras estacionárias.

\section{3}

\section{Características químicas}

- Poder calorífico

- Potencial hidrogeniônico $(\mathrm{pH})$

- Composição química

- Relação Carbono/Nitrogênio (C: N)

\subsection{1}

\section{Poder calorífico}

Esta característica química indica a capacidade potencial de um material desprender determinada quantidade de calor quando submetido à queima. O poder calorífico médio do lixo domiciliar se situa na faixa de $5.000 \mathrm{kcal} / \mathrm{kg}$. Fornece os 
parâmetros das instalações de todos os processos de tratamento térmico (incineração, pirólise e outros).

\section{3 .2}

\section{Potencial hidrogeniônico (pH)}

O potencial hidrogeniônico indica o teor de acidez ou alcalinidade e o grau de corrosividade dos resíduos coletados. servindo para estabelecer o tipo de proteção contra a corrosão a ser usado em veículos, equipamentos, contêineres e caçambas metálicas. Em geral, situa-se na faixa de 5 a 7 .

\subsection{3}

\section{Composição química}

A composição química consiste na determinação dos teores de cinzas, matéria orgânica, carbono, nitrogênio, potássio, cálcio, fósforo, resíduo mineral total, resíduo mineral solúvel e gorduras. Ajuda a encontrar a forma mais adequada de tratamento para os resíduos coletados.

\subsection{4}

\section{Relação carbono/nitrogênio (C: N)}

A relação carbono/nitrogênio fornece o grau de decomposição da matéria orgânica do lixo nos processos de tratamento/disposição final. Em geral, essa relação encontra-se na ordem de 35/1 a 20/1. Fundamental para estabelecer a qualidade do composto produzido.

\section{4}

\section{Características biológicas}

As características biológicas do lixo são determinadas pela população microbiana e pelos agentes patogênicos, que, ao lado das suas características químicas, permitem sejam selecionados os métodos de tratamento e disposição finais mais adequados. 
O conhecimento das características biológicas dos resíduos tem sido muito utilizado no desenvolvimento de inibidores de cheiro e de retardadores/ aceleradores da decomposição da matéria orgânica, normalmente aplicados no interior de veículos de coleta para evitar ou minimizar problemas com a população ao longo do percurso dos veículos. Da mesma forma, estão em desenvolvimento processos de destinação final e de recuperação de áreas degradadas com base nas características biológicas dos resíduos.

\section{Fatores externos antrópicos e ambientais relevantes nas características dos RSU}

A Tabela 7 apresenta a relação entre os valores que revelam as características físicas dos resíduos, principalmente aquelas muito influenciadas por fatores sazonais e que podem conduzir a conclusões equivocadas no planejamento da coleta. Por exemplo, na época de chuvas fortes o teor de umidade no lixo cresce, e durante o Carnaval há um aumento do percentual de alumínio (latas de cerveja e de refrigerantes). 
Tabela 7 - Fatores e influências na geração de resíduos.

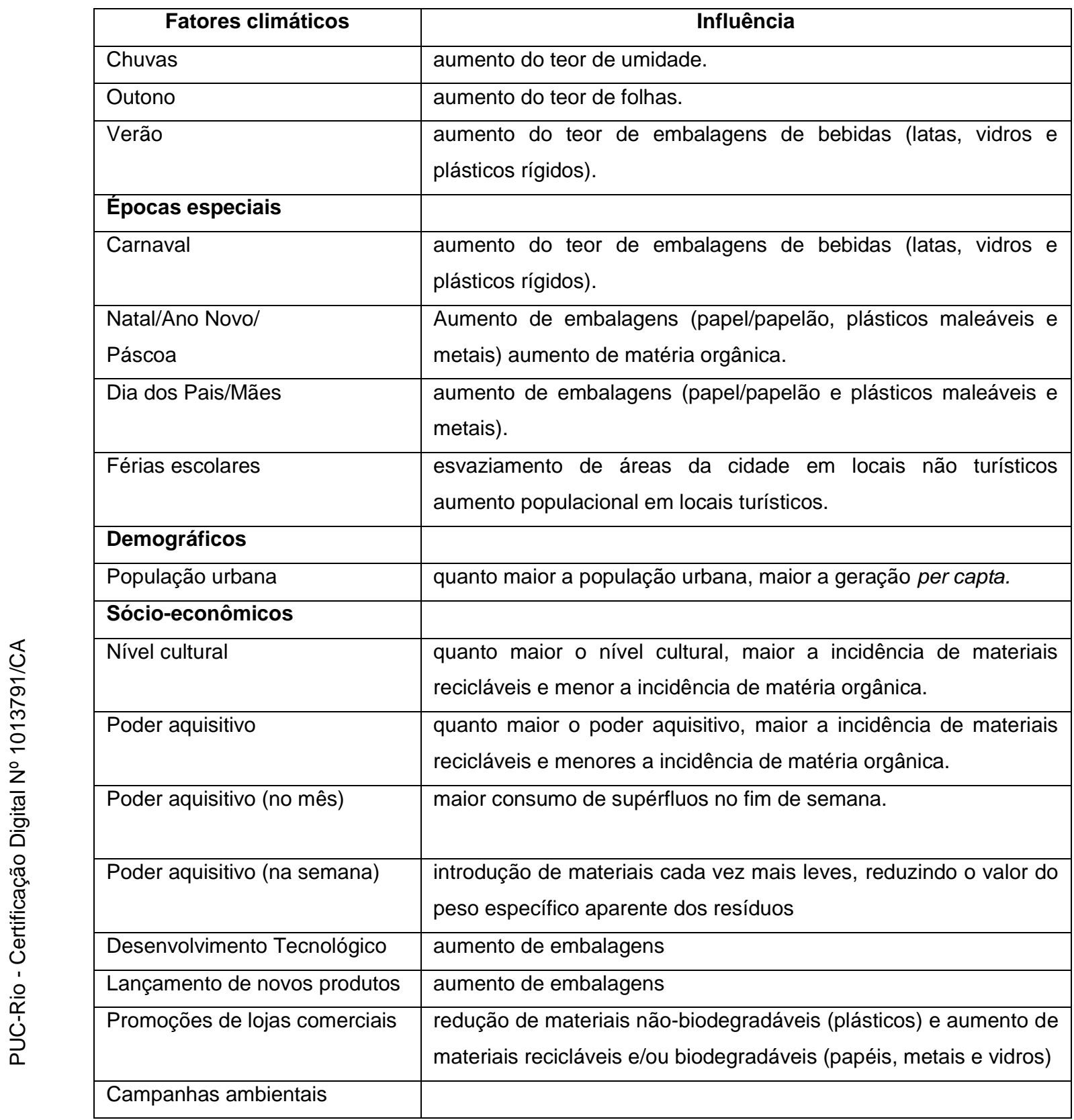

Fonte: Monteiro, 2001.

\section{5}

\section{Acondicionamento, coleta e transporte de RSU}

\subsection{1}

\section{Acondicionamento de RSU}

Acondicionar os resíduos sólidos domiciliares significa prepará-los para a coleta de forma sanitariamente adequada, como ainda compatível com seu tipo e a 
quantidade (MONTEIRO, 2001). A qualidade da operação de coleta e transporte de lixo depende disto e da disposição dos recipientes no local, dia e horários estabelecidos pelo órgão de limpeza urbana para a coleta. A população deve ter uma participação significativa nesta operação.

A importância do acondicionamento adequado está em:

- evitar acidentes; possibilitar uma manipulação segura por parte da equipe de coleta;

- atender às condições sanitárias: exemplo: evitar a proliferação de vetores;

- minimizar o impacto visual e olfativo;

- reduzir a heterogeneidade dos resíduos (no caso de haver coleta seletiva);

- ter capacidade para conter o lixo gerado durante o intervalo entre uma coleta e outra;

- facilitar a realização da etapa da coleta, permitindo que se faça uma coleta rápida, aumentando a produtividade do serviço;

Nas cidades brasileiras, a população utiliza os mais diversos tipos de recipientes para acondicionamento do lixo domiciliar:

- vasilhames metálicos (latas) ou plásticos (baldes);

- sacos plásticos de supermercados ou especiais para lixo;

- caixotes de madeira ou papelão;

- latões de óleo, algumas vezes cortados ao meio;

- contêineres metálicos ou plásticos, estacionários ou sobre rodas;

- embalagens feitas de pneus velhos

Em muitas cidades, acontece o surgimento espontâneo de pontos de acumulação de lixo domiciliar a céu aberto, expostos indevidamente ou espalhados nos logradouros. $\mathrm{O}$ aspecto cultural no acondicionamento de lixo no Brasil influencia bastante nos custos da gestão dos RSU. 
A escolha do tipo de recipiente mais adequado deve ser orientada em função:

- das características do lixo;

- da geração do lixo;

- dafrequência da coleta;

- do tipo de edificação;

- do preço do recipiente.

Os recipientes adequados para acondicionar o lixo domiciliar devem ter as seguintes características:

- peso máximo de $30 \mathrm{~kg}$, incluindo a carga, se a coleta for manual;

- recipientes que permitem maior carga devem ser padronizados para que possam ser manuseadas por mecanismo dos próprios veículos coletores, reduzindo assim o esforço humano;

- dispositivos que facilitem seu deslocamento no imóvel até o local de coleta;

- serem herméticos, para evitar derramamento ou exposição dos resíduos;

- as embalagens flexíveis (sacos plásticos) devem permitir fechamento adequado das "bocas"; as rígidas e semi-rígidas (vasilhames, latões, contêineres) devem possuir tampas e estabilidade para não tombar com facilidade;

- serem seguros, para evitar que lixo cortante ou perfurante possa acidentar os usuários ou os trabalhadores da coleta;

- serem econômicos, de maneira que possam ser adquiridos pela população;

- não produzir ruídos excessivos ao serem manejados;

- possam ser esvaziados facilmente sem deixar resíduos no fundo.

Há ainda outra característica a ser levada em conta: se os recipientes são com ou sem retorno. Neste último caso, a coleta será mais produtiva e não haverá 
exposição de recipientes no logradouro após o recolhimento do lixo, tampouco a necessidade de seu asseio por parte da população.

Chega-se à conclusão que os sacos plásticos são as embalagens mais adequadas para acondicionar o lixo quando a coleta for manual, porque:

- são facilmente amarrados nas "bocas", garantindo o fechamento;

- são leves, sem retorno (resultando em coleta mais produtiva) e permitem recolhimento silencioso, útil para a coleta noturna;

- possuem preço acessível, permitindo a padronização; pode-se tolerar o uso de sacos plásticos de supermercados (utilizados para embalar os produtos adquiridos), sem custo para a população.

O saco plástico de polietileno, sendo composto por Carbono, Hidrogênio e Oxigênio, não polui a atmosfera quando corretamente incinerado. Não é biodegradável, mas como os aterros sanitários são métodos de destino praticamente definitivos, não há maiores objeções ao uso de sacos plásticos de polietileno para o acondicionamento do lixo domiciliar.

Como a maioria da população utiliza os sacos plásticos de supermercados para guardar o lixo produzido, para reduzir o risco de ferimento para os garis que efetuam a coleta, basta que estes utilizem luvas. Já os sacos plásticos com mais de 100 litros não são seguros, pois os coletores tendem a abraçá-los para carregá-los até o caminhão. Os vidros e outros objetos cortantes ou perfurocortantes contidos no lixo podem feri-los. (MONTEIRO, 2001).

\section{5 .2}

\section{Acondicionamento de resíduo público}

Papeleiras de rua: Cesta coletora plástica, do tipo papeleira, com capacidade volumétrica útil de 50 litros, constituída de corpo para recebimento dos resíduos e soleira metálica para apagar ponta de cigarro a ser jogado no seu interior e contendo na matéria-prima um pouco de material reciclado e aditivos contra a ação de raios ultravioleta.

Esses recipientes são próprios para pequenos resíduos e refugos descartados por pedestres em trânsito nos logradouros. Devem ser instaladas nos 
parques, praças, jardins, ruas, avenidas e demais locais públicos onde haja maior concentração de pessoas (pontos de ônibus, cinemas. lanchonetes. bares etc.). com o objetivo de reduzir a quantidade de lixo disposta no solo. As cestas devem ter as seguintes características:

- pequena, para não atrapalhar o trânsito de pedestres pelas calçadas;

- durável, bonita e integrada com os equipamentos urbanos já existentes;

- sem tampa, pois o usuário, certamente, não gostará de tocá-la;

- fácil de esvaziar diretamente nos equipamentos auxiliares dos varredores.

Cesta coletora plástica para pilhas e baterias: Cesta coletora plástica de pilhas e baterias, do tipo papeleira, com capacidade volumétrica útil de 50 litros, fabricada em polietileno de alta densidade, protegido contra a ação de raios ultravioleta, constituída de recipiente inferior e tampa.

Destina-se ao recebimento de pilhas e baterias, através de furo circular na parte frontal da tampa. As cestas devem ser instaladas nos parques, praças, jardins, ruas, avenidas e demais locais públicos de trânsito de pessoas para facilitar o recolhimento das pilhas e baterias.

Sacos plásticos e contêineres: Os sacos plásticos utilizados no acondicionamento do lixo público são similares aos usados para embalar o lixo domiciliar. A única diferença está no volume, pois, para lixo público, é aceitável o uso de sacos de 150 litros.

Da mesma forma, os contêineres plásticos são exatamente os mesmos utilizados no acondicionamento do lixo domiciliar, havendo variação apenas nos contêineres metálicos.

Os contêineres metálicos utilizados no acondicionamento do lixo público são recipientes estacionários, com capacidade de 5 ou $7 \mathrm{~m}^{3}$, que podem ser basculados.

Essas caixas metálicas são intercambiáveis. O veículo que as recolhe quando estão cheias traz consigo uma outra, vazia, para continuar servindo o 
local. Por isso esse sistema se chama "Canguru". Já os veículos que operam essas caixas são os poliguindastes, pelo fato de serem dotados de um guindaste servindo a vários propósitos. O sistema também é conhecido como "Brooks" e as caixas como "caixas Dempster", como mostra a figura 19.

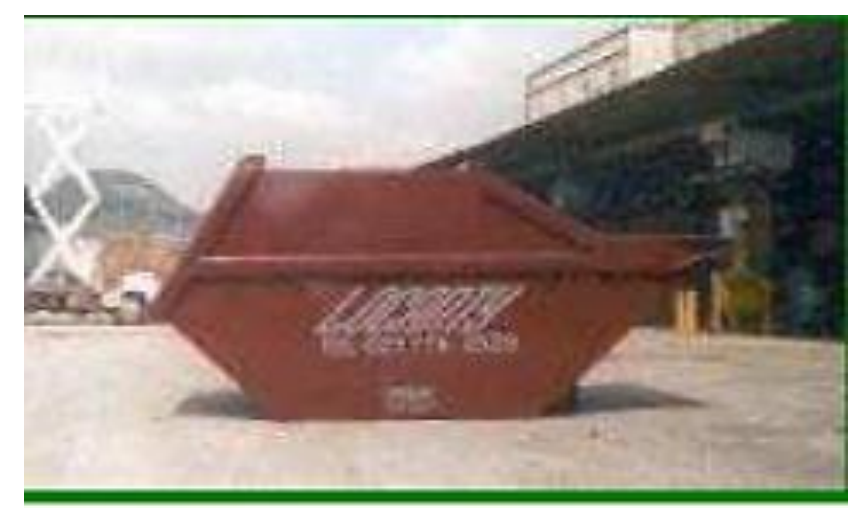

Figura 19 - Caçamba Estacionária ou Caixa Dempster / Brooks.

Fonte: Porto Maravilha, 2013

\section{Cenário dos RSU no Brasil}

No ano de 2011, foi sancionada a lei que instituiu a Politica Nacional de Resíduos Sólidos, (PNRS) o marco regulatório do setor.

A lei estabelece a distinção entre resíduo, o que é lixo reciclável, e o que é rejeito que não pode ser aproveitado, e faz a classificação dos tipos de detrito (doméstico, industrial, eletroeletrônico, da construção civil, da área de saúde etc.). Uma de suas determinações é que se dê tratamento adequado a cada tipo de lixo e que se intensifique a reciclagem, com ênfase na chamada logística reversa, que tem como principais pontos:

1. Poluidor-pagador: o fabricante que coloca no mercado um produto que, com sua utilização, se torna resíduo, fica responsável por ele durante todo o seu ciclo de vida.

2. Responsabilidade compartilhada: a responsabilidade é compartilhada por todos os agentes econômicos que se envolveram no ciclo de vida do produto 
3. Sustentabilidade: a implementação de um sistema que garanta a integração de aspectos econômicos, ambientais e sociais na política pública para a gestão integrada de RSU.

A lei também proíbe a criação de lixões - todas as prefeituras do país terão de construir até 2014, aterros sanitários ambientalmente sustentáveis em que só poderão ser depositados resíduos sem possibilidade de reaproveitamento. Fica vetado catar lixo, morar ou criar animais nesses aterros.

Em metade dos 5.565 municípios brasileiros os resíduos são despejados nos lixões a céu aberto, que são pontos clandestinos (ou quase), em que tudo é jogado e nada é tratado, sem qualquer tipo de proteção ao meio ambiente. Estão geralmente associados à presença de animais e de pessoas, que, algumas vezes, residem no próprio local.

Porém em muitos casos, o problema ocorre também pela cobertura deficiente da coleta. Esta é uma situação familiar a todas as cidades brasileiras: a população de renda mais baixa ocupa morros, mangues, lugares onde o acesso é difícil. Os veículos empregados normalmente na limpeza urbana costumam ser impróprios para operar nessas áreas. A consequência imediata é o despejo do lixo produzido em encostas, valas, cursos de água.

Para enfrentar o problema, costuma-se escolher determinados locais para a acumulação dos resíduos produzidos por moradores das cercanias. São os chamados "pontos de lixo", que tem de ser acessíveis aos veículos coletores e devem ser providos de algum tipo de acondicionamento.

Geralmente nos grandes municípios brasileiros, 5 a 10\% do lixo produzido não é coletado, devido aos acessos difíceis, favelas, costumes inadequados da população que queimam ou despejam em córregos e terrenos baldios.

Constata-se então que os lixões a céu aberto, os aterros controlados e aterros sanitários, são as formas de disposição de resíduos no solo mais utilizados pela população brasileira, conforme a demonstra a tabela 8 . 
Tabela 8 - Quantidade de resíduos encaminhados para disposição em solo, considerando somente lixão, aterro controlado e aterro sanitário no Brasil.

\begin{tabular}{|c|c|c|c|c|c|c|}
\hline \multirow{3}{*}{$\begin{array}{l}\text { Unidade de } \\
\text { análise } \\
\text { PNSB }\end{array}$} & \multicolumn{6}{|c|}{$\begin{array}{l}\text { Quantidade de resíduos e rejeitos encaminhados para disposição no solo, } \\
\text { considerando somente lixão, aterro controlado e aterro sanitário(t/dia) }\end{array}$} \\
\hline & \multicolumn{2}{|c|}{ Lixão } & \multicolumn{2}{|c|}{ Aterro Controlado } & \multicolumn{2}{|c|}{ Aterro sanitário } \\
\hline & 2000 & 2008 & 2000 & 2008 & 2000 & 2008 \\
\hline Brasil & $45.484,70$ & $37.360,80$ & $33.854,3$ & $36.673,20$ & $49.614,5$ & $110.044,40$ \\
\hline \multicolumn{7}{|c|}{ Estrato Populacional } \\
\hline $\begin{array}{l}\text { Municipios } \\
\text { pequenos }\end{array}$ & $34.533,10$ & $32.504,30$ & $10.405,90$ & $14.067,90$ & $6.878,40$ & $32.420,50$ \\
\hline $\begin{array}{l}\text { Municipios } \\
\text { médios }\end{array}$ & $10.119,60$ & $4.844,50$ & $15.525,50$ & $17.278,30$ & $17.105,80$ & $45.203,40$ \\
\hline $\begin{array}{l}\text { Municípios } \\
\text { grandes }\end{array}$ & 832,00 & 12,00 & $7.922,90$ & $5.327,00$ & $25.630,30$ & $32.420,50$ \\
\hline \multicolumn{7}{|c|}{ Macrorregião } \\
\hline Norte & $6.148,50$ & $4.892,50$ & $3.221,8$ & $4.688,20$ & $1.350,2$ & $4.540,60$ \\
\hline Nordeste & $20.579,60$ & $23.461,50$ & $6.113,1$ & $6.819,00$ & $6.714,9$ & $25.246,60$ \\
\hline Sudeste & $11.521,00$ & $3.636,20$ & $15.685,6$ & $16.767,00$ & $32.568,4$ & $61.576,80$ \\
\hline Sul & $4.645,80$ & $1.432,80$ & $4.698,8$ & $3.485,00$ & $5.882,1$ & $15.293,10$ \\
\hline Centro-Oeste & $2.589,80$ & $3.937,80$ & $4.135,0$ & $4.914,00$ & $3.098,9$ & $3.387,30$ \\
\hline
\end{tabular}

Fonte: ABRELPE, (2011).

\section{6}

\section{Custos da Limpeza Urbana}

\subsection{1}

\section{Custos da limpeza urbana no Brasil}

No Brasil, conforme previsto na Constituição Federal, compete aos municípios, legislar sobre assuntos de interesse local e organizar os serviços públicos. Por isso a gestão da limpeza urbana e dos resíduos gerados em seu território é de responsabilidade do município. De acordo com a Política Nacional de Saneamento, os municípios devem estabelecer planos específicos para os diferentes serviços de saneamento, bem como para o serviço de limpeza urbana e 
de manejo de resíduos sólidos, ou podem juntá-los em um único plano de saneamento básico. (PRICEWATERHOUSECOOPERS, 2010).

Qualquer serviço de limpeza urbana deve conter prioridades máximas na sua execução e, além da coleta e do transporte, providenciar um destino final adequado para todo o lixo gerado no município; buscar formas de tratamento para os resíduos gerados; promover campanhas ou implantar programas educacionais voltados à conscientização da limpeza da cidade e incentivar medidas que visem à diminuição da própria produção de lixo.

As principais despesas relacionadas à gestão de resíduos sólidos são:

- combustível;

- aquisição de máquinas, equipamentos e ferramentas, como caminhões, carregadeiras, retroescavadeiras, compactadores, entre outros;

- manutenção e conservação de equipamentos e veículos;

- recursos humanos próprios (trabalhadores fixos e temporários), incluindo encargos sociais e trabalhistas;

- recursos humanos contratados e terceiros (trabalhadores fixos e temporários), incluindo encargos sociais e trabalhistas;

- depreciação de máquinas e equipamentos;

- materiais consumíveis como utensílios, uniformes, entre outros; equipamentos de proteção individual e de proteção coletiva,

- seguros e licenciamentos de veículos;

- infraestrutura, como imóveis, telefone, energia, entre outros;

- inovação tecnológica, pesquisas e projetos piloto.

\section{A limpeza urbana nos orçamentos municipais no Brasil}

A tabela 13 demonstra que, em muitas cidades brasileiras, a coleta de resíduos sólidos consome um percentual bastante significativo do orçamento municipal. Ultrapassa, em algumas, os gastos com serviços de saúde pública. (PRICEWATERHOUSECOOPERS 2010). 
Tabela 9 - Percentual do orçamento municipal destinado à limpeza urbana.

\begin{tabular}{|l|l|l|l|l|}
\hline Brasília - DF & Salvador & Rio de Janeiro & Goiânia & São Paulo \\
\hline $4,7 \%$ & $12,5 \%$ & $6,8 \%$ & $7,8 \%$ & $5,3 \%$ \\
\hline
\end{tabular}

Fonte: Sistema Nacional de Informações sobre Saneamento - SNIS (2008).

\subsection{2}

\section{Custos da limpeza urbana no mundo}

Os custos da limpeza urbana estão divididos entre coleta, varrição, tratamento e disposição final dos RSU. Diversas variáveis influenciam esses custos, como o número de empregados, os salários, a abrangência do atendimento, a frequência, a logística, a reciclagem e a qualidade dos serviços prestados. Existem ainda questões culturais, como o consumismo, o desperdício e a falta de conscientização da população, que podem afetá-los diretamente.

A Figura 20 apresenta uma comparação dos custos per capita dos serviços de limpeza urbana nas cidades selecionadas. Se considerado o valor médio, os municípios brasileiros apresentam valores significativamente inferiores às médias das cidades internacionais analisadas. 


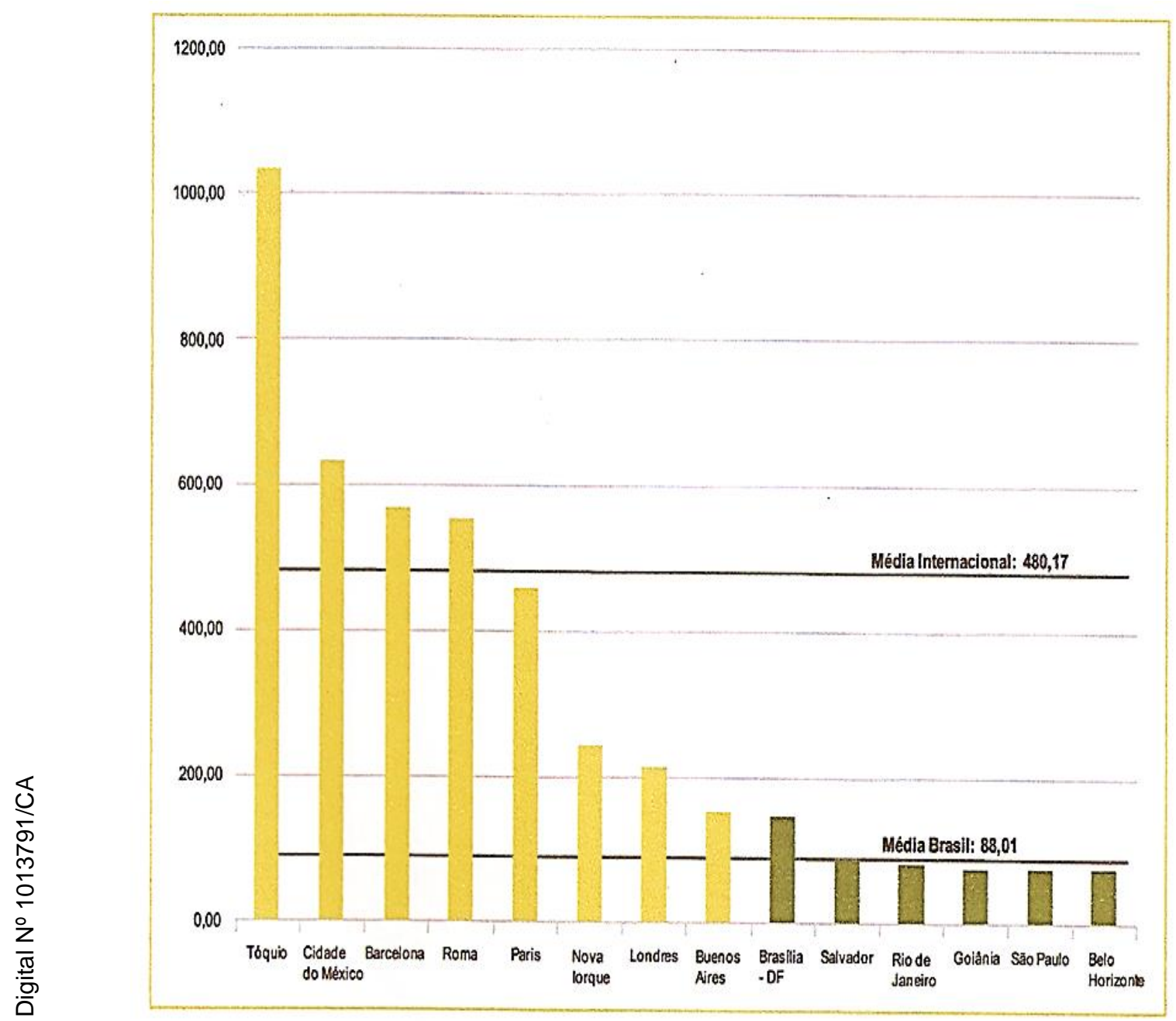

Figura 20 - Custos per capita dos serviços de limpeza urbana nas cidades.

Fonte: Sistema Nacional de Informações sobre Saneamento - SNIS (2008).

Um estudo recente realizado pela PwC, 2010, pelo Sindicato das Empresas de Limpeza Urbana no Estado de São Paulo - SELUR e pela Associação Brasileira de Resíduos Sólidos e Limpeza Pública - ABLP demonstrou que o valor aplicado em gestão de resíduos no Brasil por habitante/ano é de $\mathrm{R} \$ 88,01$. Isso justifica os baixos níveis de investimento e consequentemente a incorreta forma de destinação dos resíduos observada na maioria dos municípios.

Comparando Nova Iorque com São Paulo em relação à quantidade de trabalhadores por habitante tem-se: um para 800 habitantes em Nova Iorque e um para aproximadamente 1.000 habitantes em São Paulo.

A figura 21 a seguir mostra que os custos com limpeza urbana em Nova Iorque são três vezes maiores do que em São Paulo; importa porém devemos considerar o valor do salário mínimo, assim como o valor econômico da moeda. 
Já Brasília apresenta o maior custo per capita em decorrência da longa distância a ser percorrida para atingir a maior parte da população.

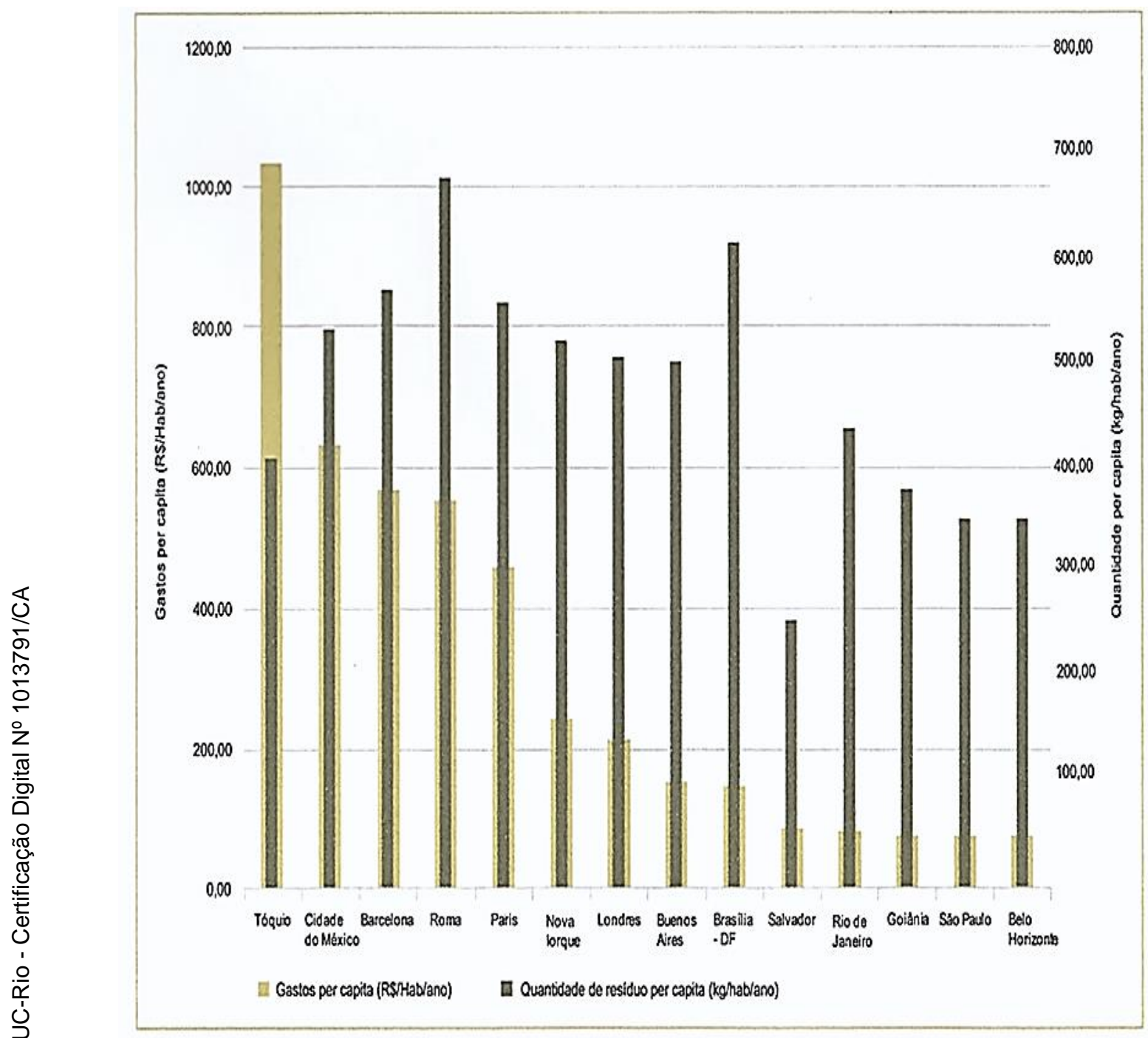

Figura 21 - Comparação dos gastos per capita dos serviços de limpeza urbana nas cidades com a quantidade de resíduo per capita.

Fonte: PRICEWATERHOUSECOOPERS (2010).

Através deste gráfico nota-se que as cidades internacionais estudadas produzem aproximadamente $20 \%$ mais de resíduo por habitante, do que as brasileiras, porém gastam cerca de 5 vezes mais em limpeza urbana. Por exemplo, na tabela 14, pode ser visto que Tóquio gera cerca de $400 \mathrm{Kg} / \mathrm{hab}$. /ano em comparação a $350 \mathrm{Kg}$ / hab. /ano de São Paulo, porém investe 13 vezes mais por habitante. 
Tabela 10 - Resumo das principais informações entre cidades selecionadas.

\begin{tabular}{|c|c|c|c|c|c|c|}
\hline Cidades & $\begin{array}{l}\text { Populaçăo } \\
\text { urbana } \\
\text { (milhöes de } \\
\text { habitantes) }\end{array}$ & Área $\left(\mathrm{km}^{2}\right)$ & $\begin{array}{l}\text { Quantidade } \\
\text { de residuo } \\
\text { coletado } \\
\text { (mil ton/ano) }\end{array}$ & $\begin{array}{l}\text { Quantidade } \\
\text { de residuo } \\
\text { per capita } \\
\text { (kg/hab/ano) }\end{array}$ & $\begin{array}{l}\text { Gastos } \\
\text { com SLU } \\
\text { (milhöes R\$) } \\
\text { ano) }\end{array}$ & $\begin{array}{l}\text { Gastos per } \\
\text { capita com } \\
\text { SLU } \\
\text { (R\$/hab/ano) }\end{array}$ \\
\hline Tóquio & 12,06 & $2.187,08$ & 4.970 & 412,11 & 12.500 & $1.036,48$ \\
\hline Cidade do México & 8,72 & 1.479 & 4.600 & 527,52 & 5.513 & 632,22 \\
\hline Barcelona & 1,5 & 91,4 & 848 & 565,33 & 846 & 564,00 \\
\hline Roma & 2,72 & 1.285 & 1.829 & 672,43 & 1.501 & 551,84 \\
\hline Paris & 2,17 & 105 & 1.204 & 554,84 & 988 & 455,30 \\
\hline Nova lorque & 8,14 & $1.214,4$ & 4.307 & 529,12 & 1.950 & 239,56 \\
\hline Londres & 8,28 & 1.579 & 4.200 & 507,25 & 1.747 & 210,99 \\
\hline Buenos Aires & 2,97 & 203 & 1.469 & 494,64 & 449 & 151,01 \\
\hline Brasilia - DF & 2,27 & 5.802 & 1.379 & 605,02 & 329 & 144,45 \\
\hline Salvador & 2,71 & 707 & 687 & 253,31 & 230 & 84,99 \\
\hline Rio de Janeiro & 6,13 & 1.182 & 2.802 & 456,56 & 498 & 81,18 \\
\hline Goiânia & 1,21 & 739 & 447 & 368,65 & 91 & 75,80 \\
\hline São Paulo & 10,36 & 1.523 & 3.641 & 351,41 & 770 & 73,63 \\
\hline Belo Horizonte & 2,39 & 331 & 838 & 349,13 & 163 & 68,04 \\
\hline
\end{tabular}

Fonte: PRICEWATERHOUSECOOPERS (2010).

\section{7}

\section{Coleta e transporte de RSU}

No sistema de limpeza urbana, a coleta de resíduos é etapa essencial. Compreende a operação de regular recolhimento do lixo acondicionado, sua remoção, o transporte, o tratamento e encaminhamento para a disposição final.

A coleta requer um veículo e um conjunto de empregados. Deve atender às demandas nos segmentos de ruas, respeitando as restrições existentes e deve ser feita reduzindo custos, principalmente o do combustível, cuja característica não linear de seu consumo dificulta a elaboração de um sistema eficaz para atingir esse objetivo.

O consumo de combustível é a parcela de maior peso no custo operacional da coleta e dependente da velocidade de deslocamento do veículo (velocidade de coleta, trânsito urbano e em rodovias) e da sua carga (cheio, vazio e carregando). 
Em estudo de 1996, Bhat, partindo do princípio que os custos relativos à coleta e transporte de resíduos sólidos são responsáveis por 75 a $80 \%$ do orçamento disponibilizado para o gerenciamento dos resíduos, conclui que uma melhoria do consumo de combustível produz resultados significativos.

Na norma NBR i 12980 [abn, 1993] encontram-se as definições dos diferentes tipos de serviço de coleta de resíduos sólidos:

Coleta domiciliar: consiste na coleta de lixo de residências, estabelecimentos comerciais e industriais cujo volume não ultrapasse o previsto em legislação municipal. A coleta e o transporte do lixo domiciliar são, em geral, efetuados pelo órgão municipal encarregado da limpeza urbana. Para esses serviços, podem ser usados recursos próprios da prefeitura e de empresas sob utilização de mão-deobra da prefeitura, como podem ser terceirizados por meio de concessão. O lixo dos "grandes geradores" (estabelecimentos que produzem mais que 120 litros de lixo por dia) deve ser coletado por empresas particulares, cadastradas e autorizadas pela prefeitura.

Segundo Fonseca (2006), a geração per capita não pode ser correlacionada somente ao lixo domiciliar (doméstico + comercial), mas, sim, aos resíduos urbanos (domiciliar + público + entulho, incluindo os resíduos de serviços de saúde).

Estudos realizados pela Superintendência de Limpeza Urbana de Belo Horizonte (2006) indicaram a seguinte variação com relação ao total de lixo urbano:

- Lixo Domiciliar = 50 a 60\% (lixo doméstico e comercial)

- Lixo Público = 20 a 30\% (varrição, podas, capina etc)

- Entulhos = 20 a $30 \%$

- $\quad$ Lixo Hospitalar $=1 \%$

- $\quad$ Total de Lixo Urbano $=100 \%$

Coleta pública: referente ao recolhimento dos resíduos provenientes de feiras, praias, calçadas e demais áreas de uso público, através da varrição ou varredura, que é a principal atividade de limpeza de logradouros públicos. Os resíduos comumente encontrados nos logradouros urbanizados são: 
- partículas resultantes da abrasão da pavimentação;

- borracha de pneus e resíduos de pastilhas e lonas de freios;

- areia e terra trazidas por veículos ou provenientes de terrenos ou encostas;

- folhas e galhos de árvores, mato e ervas daninhas;

- papéis, plásticos, jornais, embalagens;

- lixo domiciliar (geralmente em pequenas quantidades, principalmente em alguns terrenos baldios e em áreas próximas a favelas);

- dejetos de cães e de outros animais (também em pequena quantidade);

- partículas resultantes da poluição atmosférica

O lixo vai sendo acumulado durante a varredura. Os recipientes, uma vez cheios, são vazados em um local previamente determinado (ponto de lixo), de onde se providencia o seu recolhimento e transporte até a destinação final.

Coleta de serviços de saúde: engloba hospitais, postos de saúde, laboratórios, farmácias, clínicas veterinárias e outras afins. De acordo com as normas vigentes, a coleta de resíduos de serviços de saúde deve ser diária, inclusive aos domingos. Os resíduos infectantes e especiais devem ser coletados separadamente dos resíduos comuns. Os resíduos radioativos devem ser gerenciados em concordância com resoluções da Comissão Nacional de Energia Nuclear - CNEN. Os resíduos infectantes e parte dos resíduos especiais devem ser acondicionados em sacos plásticos brancos leitosos e colocados em contêineres basculáveis mecanicamente em caminhões especiais para coleta de resíduos de serviços de saúde. Tais resíduos representam no máximo 30\% do total gerado.

Caso não exista segregação do lixo infectante e especial, os resíduos produzidos devem ser acondicionados, armazenados, coletados e dispostos como infectantes e especiais. O lixo comum deve ser recolhido pela coleta normal ou ordinária. 
Coleta seletiva: visa recolher os resíduos separados na fonte. Está relacionada com a triagem, reutilização, reciclagem e a compostagem. É o modelo mais empregado nos programas de reciclagem e consiste na separação, pela população, dos materiais recicláveis existentes nos resíduos domésticos para que posteriormente os mesmos sejam coletados por um veículo específico.

O sistema de coleta seletiva de lixo começa com o cidadão separando na sua residência, os tipos de materiais, basicamente em plásticos, vidros, restos de alimentos. Nas ruas destas cidades também é adotado este sistema, com cestas de lixo coloridas, uma para cada tipo de resíduo, para facilitar a identificação de onde depositá-lo, conforme mostra a figura 22.

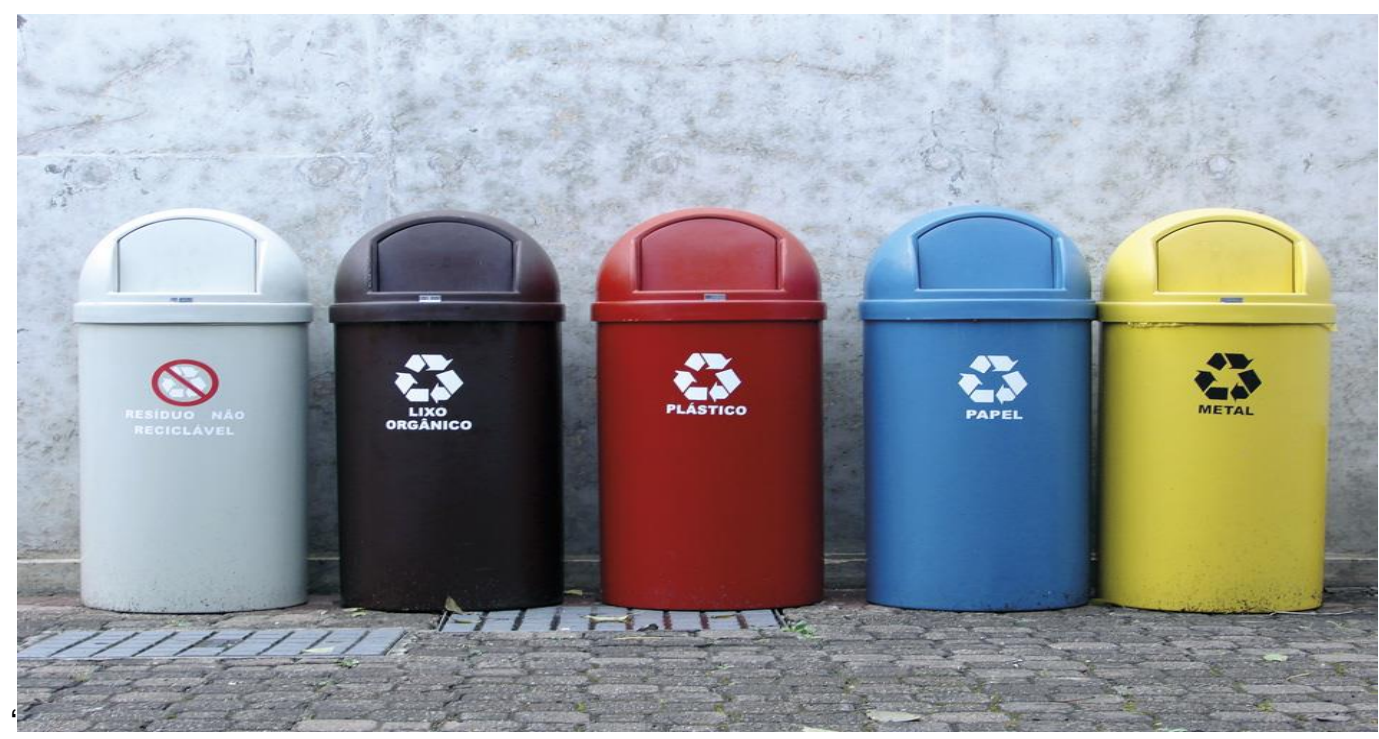

Figura 22 - Modelos de cestas coletoras de RSU para coleta seletiva (BRASIL) Fonte: Veja, (2012).

Os resíduos assim coletados são levados para as usinas de reciclagem onde passam por triagens manuais e mecânicas, promovendo a separação da parte orgânica, que resultará no composto orgânico; e da parte inorgânica, que são os materiais passíveis de reaproveitamento com destino para as indústrias. O sistema com separação individualizada dos materiais recicláveis requer considerável espaço para guarda dos contêineres, inviabilizando sua adoção em apartamentos ou em casas de pequenas dimensões. Nesse modelo, o veículo de coleta deve ter sua carroceria compartimentada de forma a transportar os materiais 
separadamente. Outro modelo, bem mais utilizado, é aquele que a população separa os resíduos domésticos em dois grupos:

- Material orgânico (úmidos) composto por restos de alimentos e materiais não recicláveis (lixo); deve ser acondicionado em um único contêiner e recolhido pelo sistema de coleta regular de lixo domiciliar.

- Materiais recicláveis (secos) compostos por papéis, metais, vidros e plásticos; devem ser acondicionados em um único contêiner e coletados nos roteiros de coleta seletiva.

Na maioria das cidades onde existe o sistema, os roteiros de coleta seletiva são realizados semanalmente, utilizando caminhões do tipo carroceria aberta.

Alguns dos problemas para a implementação da coleta seletiva porta a porta são:

- aumento das despesas com transporte em função da necessidade do aumento do número de caminhões.

- alto valor unitário, quando comparada com a coleta convencional.

Segundo Oliveira (1999), para efeito de comparação entre estes dois tipos de coleta, não podem ser desprezados os custos externos associados à poluição do ar, da água e do solo causados pela disposição dos resíduos em aterros e lixões, entre outros que tornariam significativamente mais elevado o custo da coleta convencional. Sendo assim, a internalização destes custos poderia evidenciar uma significativa vantagem da coleta seletiva sobre a coleta convencional.

É evidente que, embora a coleta seletiva tenha crescido no Brasil, ainda é pequeno o número de municípios que a realizam. É sem significação o percentual de resíduos assim coletados, como mostra a figura 23. A situação é ainda mais critica com relação aos resíduos orgânicos, pois são pouquíssimos municípios que realizam algum tratamento desses materiais, sendo o mais conhecido deles a compostagem. 
Quant.

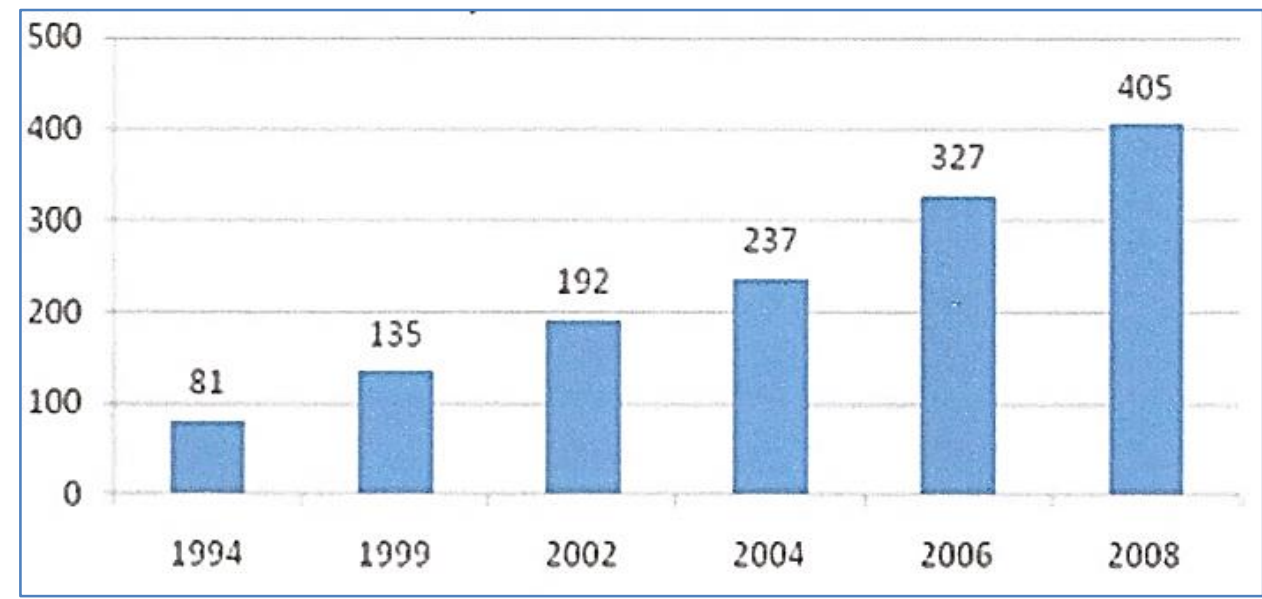

Figura 23 - Municípios com coleta seletiva no Brasil. Fonte: CEMPRE, 2008.

\section{Coleta seletiva no Rio de Janeiro, RJ}

Segundo a COMLURB (2012), a cidade do Rio de Janeiro produz cerca de 260 mil toneladas de lixo por mês (aproximadamente 8.800 toneladas por dia), mas os materiais recicláveis provenientes de coleta seletiva somam apenas 600 toneladas mensais, o que não representa nem $1 \%$ do total. As figuras 24 e 25 mostram aspectos da coleta seletiva.

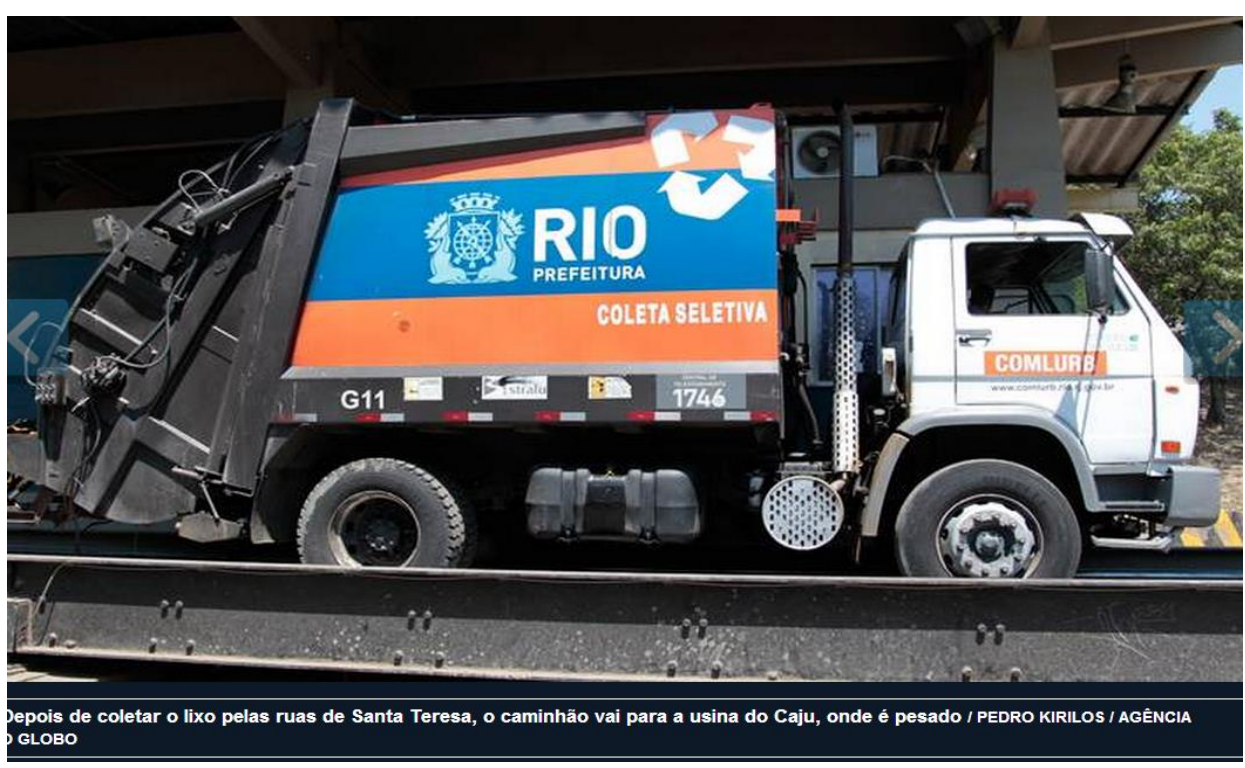

Figura 24 - Caminhão de coleta seletiva, RJ. Fonte: Kirilos, (2011). 


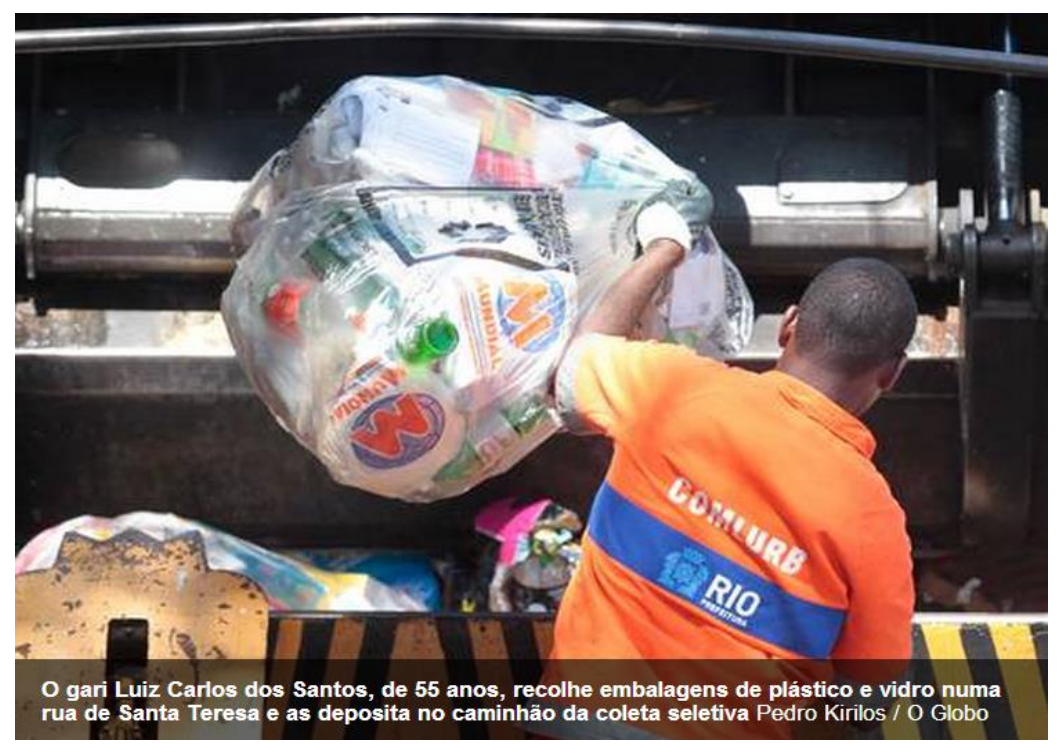

Figura 25 - Coleta seletiva Rio de Janeiro, RJ.Fonte: Kirilos, (2011).

\section{Coleta de RSU no Rio de Janeiro, RJ}

Com uma área de $1.182 \mathrm{Km}^{2}$ e contando com mais de 6 milhões de habitantes, a cidade do Rio de Janeiro está entre as primeiras economias do País, com PIB per capita de R \$ 20.851,00 ao ano. (PRICEWATERHOUSECOOPERS, 2010). A prestação de serviços de limpeza urbana na cidade do Rio de Janeiro é de responsabilidade de uma empresa de economia mista denominada Companhia Municipal de Limpeza Urbana - COMLURB.

No Brasil, o Rio de Janeiro é a capital com um dos menores custos por quilograma de resíduo sólido urbano coletado. A arrecadação destinada à limpeza urbana cobre todos os custos e ainda supera em $10 \%$ as despesas com a prestação desses serviços. A COMLURB apresenta o menor índice de terceirização (31,8\%), que corresponde apenas à sua frota e à manutenção desta.

A produção de resíduos na cidade é da ordem de 1,505 Kg/hab./dia. Cerca de $40 \%$ desse total são retirados das ruas Para executar sua limpeza, a companhia dispõe de uma frota de 1.069 veículos e 298 equipamentos, sendo 364 da própria empresa e 705 terceirizados (COMLURB, 2011). A tabela 11 mostra a quantidade de RSU coletados diariamente no RJ. 
Tabela 11 - Destino e quantidade diária de RSU, Rio de Janeiro, RJ.

\begin{tabular}{|l|l|}
\hline Destino & Município RJ \\
\hline Aterro de Gramacho (Lixo domiciliar, público eoutros) & $\mathbf{1 . 7 2 5 ~ t ~ / ~ d i a ~}$ \\
\hline CTR Gericinó (Lixo doméstico e de varredura) & 2.329 t / dia \\
\hline CTR Seropédica (Lixo domiciliar, público, e outros). & 4.771 t /dia \\
\hline TOTAL / dia & $\mathbf{8 . 8 2 5}$ t / dia \\
\hline
\end{tabular}

Ref.: Dez/2011 (média 30 dias/mês). Fonte: COMLURB.

A coleta é regular ou especial. Regular é aquela executada em determinados intervalos e a especial a que compreende o recolhimento dos resíduos não contemplados na coleta regular, tais como entulhos, animais mortos e podas de jardins; no Brasil, em razão do clima, o tempo decorrido entre a geração do lixo domiciliar e seu destino final não deve exceder uma semana, para evitar proliferação de vetores. (MONTEIRO, 2001).

A coleta particular é obrigatoriamente de responsabilidade do gerador, em decorrência do tipo de resíduo ou da sua quantidade superior à prevista em legislação municipal. Indústrias, supermercados, shopping centers, construtoras e empreiteiras, dentre outros, devem providenciar a coleta de seus resíduos em função do volume gerado. Hospitais, ambulatórios, centros de saúde e farmácias e outros similares devem ter coleta particular em função do tipo de lixo. A tabela 12 discrimina tais responsabilidades.

Tabela 12 - Responsabilidade por tipo de resíduo.

\begin{tabular}{|l|l|}
\hline Tipos de residuos & Responsabilidades \\
\hline Domiciliar & Municipio \\
\hline Comercial* & Município \\
\hline Público & Município \\
\hline Serviços de Saúde & Gerador \\
\hline Industrial* $^{*}$ & Gerador \\
\hline Portos, aeroportos, terminais ferroviários e rodoviários & Gerador \\
\hline Agricola & Gerador \\
\hline Entulho (construção civil)* $^{\star}$ & Gerador \\
\hline
\end{tabular}

* O município é corresponsável por pequenas quantidades. A quantidade máxima de resíduo varia de acordo com a legislação local.

Fonte: PRICEWATERHOUSECOOPERS, 2010. 


\section{Planejamento e determinação dos roteiros de coleta}

Planejar e dimensionar a coleta consiste em agrupar informações sobre as condições de saúde pública, a capacidade técnica do órgão que prestará o serviço, relacionadas à estimativa dos recursos necessários, isto é, tipo de veículo, quantitativo de pessoal, equipamentos e definição de como o serviço será executado, determinando as frequências, horários, roteiros. Para esse planejamento, fundamental conhecer as características da cidade e os hábitos e as reivindicações da população, para então discutir a maneira de tratar tais fatores e definir os métodos mais adequados. Podem, porém, ser apresentadas alternativas que ajudem a avaliar as atividades em cada cidade. A coleta e o transporte requerem ainda um fluxo permanente de informações, que subsidiem o seu planejamento e a sua gestão.

Os roteiros ou itinerários de coleta são definidos para que o serviço se torne o mais eficiente possível. Para tanto, a regularidade e o conhecimento dos dias e horários de coleta pela população são medidas fundamentais à consolidação dos roteiros.

Segundo D’Almeida \& Vilhena (2000), o itinerário de coleta é o trajeto que o veículo coletor percorre dentro de um setor, transportando o máximo de lixo num mínimo de percurso improdutivo, com o menor desgaste possível para a guarnição e para o veículo coletor. Dá-se o nome de percurso improdutivo aos trechos em que o veículo não realiza coleta, servindo apenas para o deslocamento de um ponto a outro. Deve-se considerar também pontos de coleta manual (sem acesso ao veículo, sendo o lixo coletado e carregado pelos coletores), trechos com percurso "morto" e manobras especiais, tais como ré e retorno.

Percurso "morto" é aquele repetido apenas para as manobras em respeito ao trânsito, com o objetivo de acesso a outros locais na sequência utilizada para a coleta. É admissível uma extensão total de percurso morto ou improdutivo correspondente a no máximo $20 \%$ da extensão total do percurso de coleta efetivamente produtivo. (D'ALMEIDA, 2000).

Os itinerários devem sempre ser projetados de forma a evitar percursos improdutivos, e para tal, os seguintes critérios devem ser adotados.

- Início da coleta próximo à garagem;

- Término da coleta próximo à área de descarga; 
- Percurso contínuo: coleta nos dois lados da rua, podendo, no entanto, fazer o percurso novamente caso a rua ou avenida tenha tráfego intenso, evitando assim o cruzamento de vias pela guarnição;

- Coleta em sentido descendente, quando feito em vias íngremes, poupando a guarnição e os veículos.

Entre os levantamentos que deverão ser executados, destacam-se:

- características topográficas

- sistema viário urbano.

Registrados em mapas os itinerários, estes deverão caracterizar o tipo de pavimentação das vias, declividade, sentido e intensidade de tráfego. Os levantamentos deverão indicar, nas áreas delimitadas, os usos predominantes, concentrações comerciais, setores industriais, locais de difícil acesso e/ou de baixa renda. E, ainda, dados sobre a população total urbana, quantidade média de moradores por residência e, caso haja, o número expressivo de moradores temporários. Além disso, devem registrar e quantificar a geração e a composição do lixo. São relevantes também os costumes da população, os mercados e feiras livres, exposições permanentes ou, em certas épocas do ano, as festas religiosas e locais preferidos para a prática do lazer. Por derradeiro, devem mencionar a disposição final do lixo.

O projeto da coleta é dinâmico e deverá ser revisado periodicamente, para observar variações quanto à geração de resíduos em cada setor, estado físico da pavimentação de ruas e outros fatores que a influenciam e podem impor alteração nos roteiros originais ou, até mesmo, nos setores de recolhimento do lixo.

O consumo de combustível depende das variáveis já citadas (velocidade de coleta, trânsito urbano e em rodovias, e da sua carga). Estas situações devem ser modeladas para se contabilizar o consumo total de combustível de uma rota. Isto permitirá conhecer o consumo real nas condições atuais e no modelo a ser desenvolvido.

A otimização de rotas de coleta de lixo traz ainda outros bons resultados que às vezes não aparecem perceptíveis ou mensuráveis. Podem ser citados: 
- Menor custo de operação.

- Melhoria da poluição ambiental.

- Maior disponibilidade da frota para manutenção.

Atualmente no Brasil, para garantir a melhoria contínua da limpeza pública, alguns municípios utilizam o geoprocessamento como uma ferramenta importante para analisar e aperfeiçoar os serviços de coleta de resíduos. Com essa tecnologia, é possível realizar diagnósticos mais precisos dos roteiros de coleta e, se necessário, adotar alternativas mais rápidas de recolhimento irregular dos resíduos. Exemplos: consideram ruas sem asfalto e estreitas, lixeiras viciadas, tempo e distâncias dos trechos produtivos e improdutivos, produção de lixo e situação atualizada do trânsito, com o auxílio de receptores GPS. (BRAGA, 2008).

\section{Cobertura do serviço}

A coleta do lixo de uma cidade deverá ter como meta atender a toda população, pois o lixo não coletado de uma determinada área e lançado em terrenos baldios, por exemplo, causará problemas sanitários que afetarão apenas à população das proximidades.

\section{Pontos de coleta dos recipientes}

Normalmente os moradores devem deixar os recipientes com o lixo na calçada, em frente às suas casas, apenas pouco tempo antes da coleta. Assim, evita-se que animais espalhem os resíduos, entre outros aspectos negativos. (RESOL, 2012).

\section{Frequência da coleta}

Frequência de coleta é o número de vezes na semana em que é feita a remoção de lixo num determinado local da cidade. Os fatores que influenciam esta decisão são (RESOL, 2012): 
- tipo de lixo gerado;

- a limitação do espaço necessário ao armazenamento do lixo pelo usuário em sua casa ou negócio;

- as condições climáticas;

- os recursos materiais e humanos à disposição do órgão prestador de serviço.

\section{Horários da coleta}

Nos bairros estritamente residenciais, a coleta deve ser feita preferencialmente durante o dia e, evitar os horários de grande movimento de veículos nas vias principais, pois interfere muitas vezes no trânsito. Há também um maior desgaste dos trabalhadores em regiões de climas quentes, com a consequente redução de produtividade. As maiores vantagens são as seguintes:

- é a mais econômica;

- possibilita melhor fiscalização do serviço.

Já nas áreas comerciais e turísticas, a coleta deve ser preferencialmente noturna. Este tipo de atividade não interfere no trânsito em áreas de tráfego muito intenso e evita a exposição do lixo à vista das pessoas durante o dia.

A coleta noturna deve ser cercada de cuidados em relação ao controle dos ruídos. As guarnições devem ser instruídas para não altear as vozes. O comando de anda/para do veículo, por parte do líder da guarnição, deve ser efetuado através de interruptor luminoso, acionado na traseira do veículo, e o silenciador deve estar em perfeito estado. O motor não deve ser levado à alta rotação para apressar o ciclo de compactação, devendo existir um dispositivo automático de aceleração, sempre operante. Veículos mais modernos e silenciosos, movidos à eletricidade, ou híbridos (diesel/gás e elétrico/gás), serão necessários no futuro, para atender às crescentes reclamações da população, especialmente nos grandes centros urbanos.

\section{Métodos da coleta}

O método, ou melhor, a maneira empregada pelos garis para a coleta de lixo, é consequência de um conjunto de fatores. Os mais importantes são: 
- a forma de utilização da mão-de-obra;

- tipo de recipientes usados pela população no acondicionamento do lixo;

- a densidade populacional da área;

- as condições de acesso existentes.

Quanto à utilização da mão-de-obra, a fórmula mais usual consiste em entregar a cada equipe ou guarnição de coleta (o motorista e os coletores) a responsabilidade pela execução do serviço em um determinado setor da cidade.

Operacionalmente cada setor corresponde a um roteiro de coleta, isto é, ao itinerário por onde deverá trafegar um dado veículo coletor para que a guarnição possa efetuar a remoção do lixo dentro de uma jornada normal de trabalho.

Em locais de alta densidade populacional, há uma maior concentração do lixo gerado. Os garis não precisam se deslocar muito para recolher grandes quantidades. A produtividade da coleta é elevada.

Nos locais de baixa densidade populacional, o uso de carrinhos com rodas de borracha para transporte de latões de 200 litros passa a ser uma opção interessante para agilizar o serviço. Os mesmos carinhos são também indicados para a coleta do lixo em ruas que, pelas suas características, impeçam a manobra ou até mesmo a entrada do caminhão coletor.

\section{Tipos de veículos coletores}

Conforme estabelecido na norma NBR 12980 [ABN, 1993] existem dois tipos de carroceria montada sobre chassi de veículos destinados à coleta de resíduos sólidos domiciliares. (MONTEIRO, 2001):

a) veículo com compactação: no Brasil, são utilizados equipamentos compactadores de carregamento traseiro ou lateral; são veículos com carrocerias fechadas contendo dispositivos mecânicos ou hidráulicos que possibilitam a distribuição e compressão dos resíduos no interior da carroceria. O sistema de carregamento pode ser traseiro, lateral ou frontal e as capacidades variam entre 5 a $25 \mathrm{~m}^{3}$. A figura 26 mostra exemplos de veículos compactadores. 


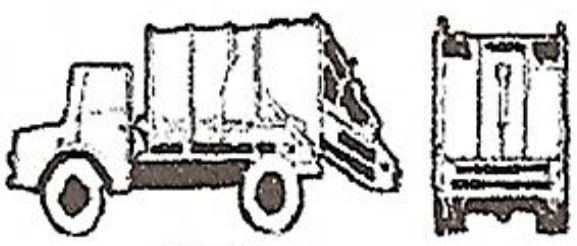

vestix
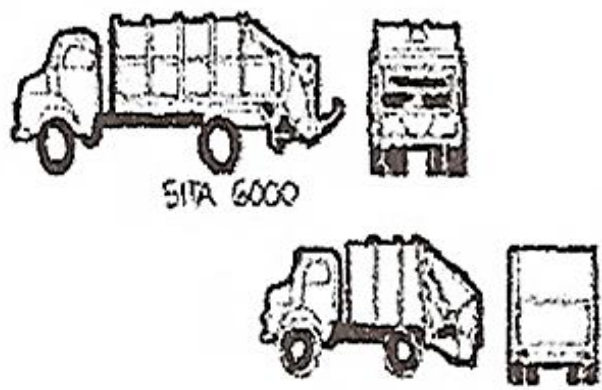

E.2 PACK
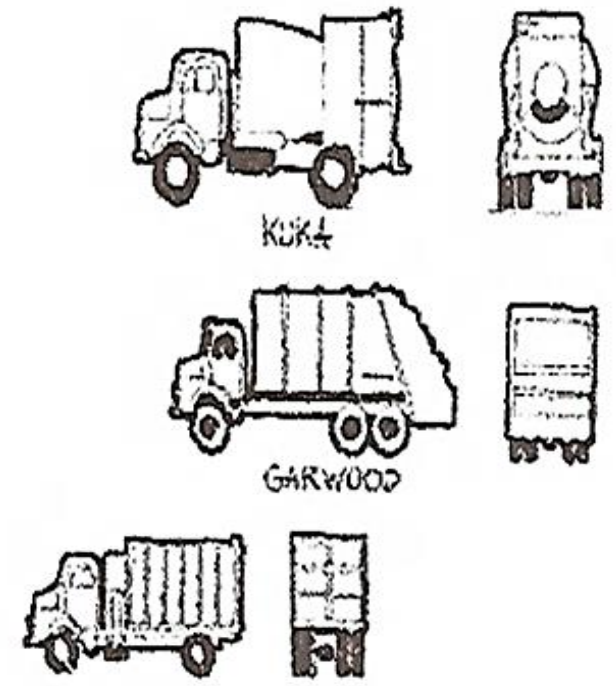

COLECCH

Figura 26 - Tipos de carrocerias compactadoras no Brasil.

b) veículos sem compactação: conhecidos como Baú ou Prefeitura. O modelo coletor tipo prefeitura se caracteriza pela carroceria fechada, metálica e construída em forma retangular, com tampas escorregadiças abauladas. É utilizado em locais íngremes, com capacidade para recolher de 4 a $15 \mathrm{~m}^{3}$ e sua carga é vazada por meio de basculamento hidráulico. É um equipamento de baixo custo de aquisição e manutenção, entretanto requer bastante esforço dos trabalhadores de coleta que devem erguer o lixo até a borda da caçamba, com mais de dois metros de altura. $\mathrm{O}$ modelo caçamba basculante difere dos anteriores por possuir a parte superior aberta, necessitando de lona para proteção da ação do vento e da poluição visual. Sua capacidade volumétrica varia entre 3 e $12 \mathrm{~m}^{3}$. A Tabela 13 mostra as carrocerias sem compactação mais utilizadas no Brasil. 
Tabela 13 - Carrocerias sem compactação mais utilizadas no Brasil.

\begin{tabular}{|c|c|c|}
\hline Tipo & Vantagens & Desvantagens \\
\hline Barculkate Convercional & \begin{tabular}{||l||} 
em outros serviços do \\
Município.
\end{tabular} & $\begin{array}{l}\text { - lixo pode se espalhar } \\
\text { pela rua devido à } \\
\text { ação do vento; } \\
\text { - a altura da carroceria } \\
\text { exige dos garis } \\
\text { grande esforço na } \\
\text { manipulação do lixo. }\end{array}$ \\
\hline Bof cu 'Prefeitura' & $\begin{array}{l}\text { - lixo coletado fica bem } \\
\text { acondicionado, evitando- } \\
\text { se que seja visto pelas } \\
\text { pessoas ou se espalhe } \\
\text { pelas ruas. }\end{array}$ & $\begin{array}{l}\text { dificulta a arrumação } \\
\text { no interior da } \\
\text { carroceria. }\end{array}$ \\
\hline
\end{tabular}

Fonte: (RESOL, 2011).

Um bom veículo de coleta de lixo domiciliar deve possuir as seguintes características:

- não permitir derramamento do lixo ou do chorume na via pública;

- apresentar taxa de compactação de pelo menos 3:1, ou seja, cada $3 \mathrm{~m}^{3}$ de resíduos ficarão reduzidos, por compactação, a $1 \mathrm{~m}^{3}$.

- apresentar altura de carregamento na linha de cintura dos garis, ou seja, no máximo a 1,20m de altura em relação ao solo;

- possibilitar esvaziamento simultâneo de pelo menos dois recipientes por vez;

- possuir carregamento de preferência traseiro;

- dispor de local adequado para transporte dos trabalhadores;

- apresentar descarga rápida do lixo no destino (no máximo em três minutos);

- possuir compartimento de carregamento (vestíbulo) com capacidade para no mínimo $1,5 \mathrm{~m}^{3}$;

- possuir capacidade adequada de manobra e de vencer aclives; 
- possibilitar basculamento de contêineres de diversos tipos;

- distribuir adequadamente a carga no chassi do caminhão;

- apresentar capacidade adequada para o menor número de viagens ao destino, nas condições de cada área;

A escolha do veículo coletor é feita considerando principalmente:

- $\quad$ as condições de operação do equipamento;

- preço de sua aquisição no mercado de chassis e equipamentos (facilidade em adquirir peças de reposição);

- custos de operação e manutenção;

- condições de tráfego da cidade;

- natureza e a quantidade do lixo.

Os equipamentos compactadores são recomendados para áreas de média a alta densidade, em vias que apresentem condições favoráveis de tráfego. Nas cidades pequenas, onde a população não é concentrada, os equipamentos sem compactação são os mais indicados. Nas cidades médias e grandes, existem áreas com características diferentes que podem justificar o uso de diversos tipos de equipamentos (caso de favelas e becos de difícil acesso, por exemplo). (RESOL, 2011).

A figura 27 mostra um caminhão poliguindaste. Este veículo possui um guindaste de acionamento hidráulico, com capacidade mínima de 7t, montado em chassi de peso bruto total mínimo de 13,5t para içamento e transporte de caixas tipo "Brooks" que acumulam resíduos sólidos. O equipamento assim constituído poderá ser do tipo simples, para transporte de uma caixa de cada vez, ou duplo, para transporte de duas caixas de cada vez.

O conjunto assim constituído, apelidado de "canguru", destina-se à coleta, transporte, basculamento e deposição de caçambas ou contêineres de até $5 \mathrm{~m}^{3}$ de capacidade volumétrica, para acondicionamento de lixo público, lixo de favelas, entulhos etc. Para ser produtivo, esse equipamento deve operar em pequenas distâncias, entre o local onde as caixas ficam estacionadas e o local de descarga. (MONTEIRO, 2001). 


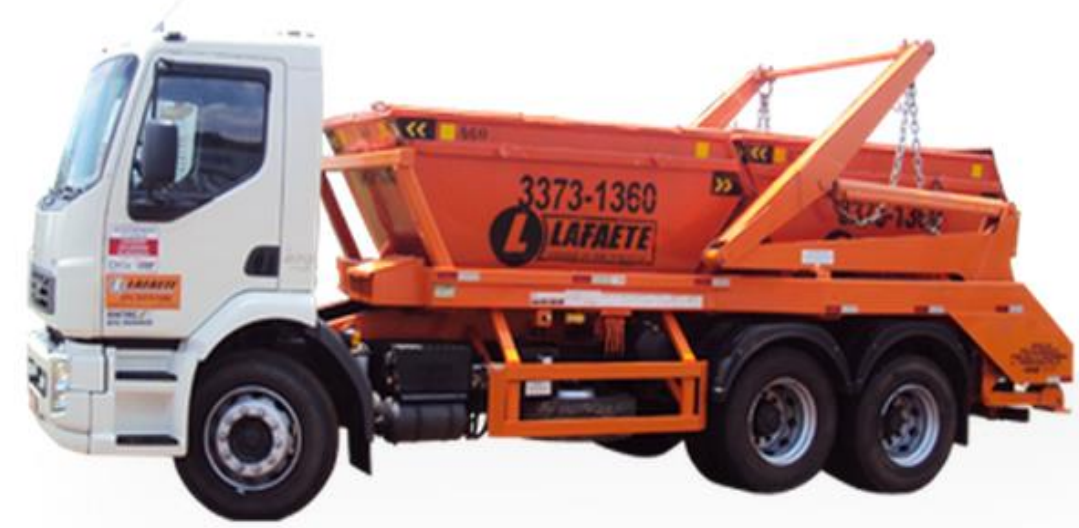

Figura 27 - Caminhão poliguindaste duplo com contêineres intercambiáveis.

Fonte: http://www.lafaetelocacao.com.br/pt/equipamentos/caminhaopoliguindast.

\section{Limpeza de logradouros}

A limpeza de logradouros inclui serviços de varrição, capinação, limpeza de sarjetas e bocas de lobo, praças e praias. Além disso, também são considerados nesta categoria poda de árvores, limpeza de monumentos, limpeza de feiras livres e limpeza e desassoreamento de valas e canais.

Esses serviços são importantes para evitar problemas sanitários à comunidade, enchentes nas ruas por causa de entupimento de bocas de lobo e acidentes de trânsito. $\mathrm{O}$ aspecto estético também é um fator que influencia a necessidade desse tipo de serviço por parte do Município. (PRICEWATERHOUSECOOPERS, 2011).

\section{Varrição}

Entre os serviços já mencionados, a principal atividade é a varrição. A atividade pode ser executada de forma mecanizada ou manual. No Brasil, em razão de mão de obra abundante e da necessidade de gerar empregos é comum que a maioria das operações de varrição seja realizada de forma manual. Como resultado, é necessário dimensionar corretamente a quantidade de garis para que não haja mão de obra ociosa. (PRICEWATERHOUSECOOPERS, 2011).

As ferramentas necessárias para execução desse tipo de serviço incluem cestas coletoras, carrinhos, vassouras, enxadas e pás. O vestuário adequado a ser 
utilizado pelos trabalhadores é calça, boné e botas, além dos equipamentos de proteção individual (EPIs).

Em caso de varrição mecanizada existem diversos tipos de equipamentos, por exemplo, minivarredeira, varredeira mecânica de médio e grande porte e minivácuo.

Estima-se que a varrição mecanizada substitui 15 varredores manuais, porém o custo dos equipamentos e da manutenção é alto. A decisão sobre o tipo de varrição a ser implantada deve ser precedido de um estudo de viabilidade para analisar o custo-benefício. Além disso, é necessário avaliar as condições das vias para que os equipamentos consigam atender às expectativas. (PRICEWATERHOUSECOOPERS, 2011).

\section{Estação de transferência}

As estações de transferência, ou transbordo, são locais onde os caminhões coletores vazam sua carga dentro de veículos com carrocerias de maior capacidade que seguem até o destino final. Têm como objetivo reduzir o tempo gasto de transporte e consequentemente os custos com o deslocamento do caminhão coletor desde o ponto final do roteiro até o local de disposição final do lixo Esta solução costuma ser empregada quando as áreas disponíveis para disposição final do lixo se encontram muito afastadas dos locais de coleta. (RESOL, 2011).

Os resíduos recolhidos nos municípios passam por uma estação de transferência, onde são classificados e encaminhados para tratamento ou eliminação, conforme o que for mais apropriado. Os resíduos recicláveis são enviados para usinas de reciclagem ou de tratamento; resíduos não recicláveis são enviados para usinas de incineração ou aterros.

As vantagens de uma estação têm de ser comparadas com os custos de aquisição, operação e manutenção de equipamentos e dos veículos de transferência. (MONTEIRO et al, 2001). 


\section{Tipos de estação}

A tabela 14 mostra que existem três alternativas básicas para a construção de estações de transferência: sem compactação e com compactação.

Tabela 14 - Tipos de estações de transferência.

\begin{tabular}{|l|l|l|}
\hline \multicolumn{1}{|c|}{ tipo } & \multicolumn{1}{|c|}{ vantagens } & \multicolumn{1}{c|}{ desvantagens } \\
\hline Sem compactação & Opção de menor investimento & $\begin{array}{l}\text { Condiciona o vazamento à } \\
\text { presença das carretas }\end{array}$ \\
\hline $\begin{array}{l}\text { Com compactador } \\
\text { estacionário }\end{array}$ & $\begin{array}{l}\text { Permite melhor aproveitamento } \\
\text { da capacidade de carga das } \\
\text { carretas }\end{array}$ & É o tipo mais caro \\
\hline $\begin{array}{l}\text { Com veículo } \\
\text { compactador }\end{array}$ & Facilita a descarga da carreta & Alto custo \\
\hline
\end{tabular}

Fonte: RESOL (2011).

Na cidade do Rio de Janeiro existem 3 estações. (COMLURB, 2011):

- Caju (triagem de materiais recicláveis e compostagem).

- Irajá (triagem de materiais recicláveis e transferência).

- Jacarepaguá. (somente estação de transferência).

\section{Sistemas modais de transferência de RSU}

Com relação à modalidade de transporte, os sistemas de transferência podem ser:

- Ferroviário: indicado para longas distâncias ou para cidades que não apresentem boas condições de tráfego rodoviário. Necessita de sistema rodoviário complementar para transportar o lixo da área de desembarque de carga até as frentes de trabalho do aterro sanitário. Os resíduos são compactados, colocados em contêineres e enviados por via férrea.

- Marítimo: mais empregado em longas distâncias, é ótima opção para cidades que contêm rios ou baías navegáveis. Os resíduos devem ser transportados preferencialmente em contêineres fechados, 
evitando-se o transporte do lixo a granel. Necessita de sistema rodoviário complementar para transportar o lixo da área de desembarque de carga até as frentes de trabalho do aterro sanitário. Utilizado em Nova York, N, EUA.

- Rodoviário: sistema mais empregado. É recomendável para distâncias médias de transporte e para locais que não tenham o sistema de tráfego saturado.

\subsection{1}

\section{Sistemas de coleta de RSU no mundo}

Algumas cidades já aproveitam o biogás dos seus aterros como combustível para os próprios veículos pesados de coleta de RSU; outras, utilizam veículos coletores alimentados por GNV/GNC/GNL provenientes de fontes diversas e ainda há as que, ainda em fase experimental, empregam veículos movidos a eletricidade por fim, as que utilizam veículos híbridos (diesel/gás, diesel/eletricidade).

\section{Toronto, Canadá}

A cidade de Toronto, no Canadá, começou a testar um novo caminhão de lixo movido a gás natural. O mais interessante é que o combustível do veículo é produzido com os mesmos resíduos que coleta. A cidade tem um biodigestor onde todo o lixo orgânico é concentrado. A decomposição desse material gera gás metano. Por isso, até pouco tempo, o metano produzido na usina biodigestora era queimado e, assim, transformado em dióxido de carbono e água. Mas é uma solução insatisfatória, porque pode produzir energia, uma vez processado até ficar semelhante ao gás natural. Isto passou a ser feito ao mesmo tempo em que a cidade experimenta novos caminhões que usam um motor a gás natural comprimido. (GNC). A produção de gás gerada pelos resíduos orgânicos deverá ser capaz de mover toda a frota local de quase 300 caminhões de lixo. Como o gás natural é muito menos poluente do que o diesel, usado até agora, o resultado líquido para o inventário de emissões de gases do efeito estufa de Toronto 
será equivalente a retirar 4 mil carros da rua. (PEGURIER, 2011). A figura 28 apresenta um modelo de caminhão movido a biogás.

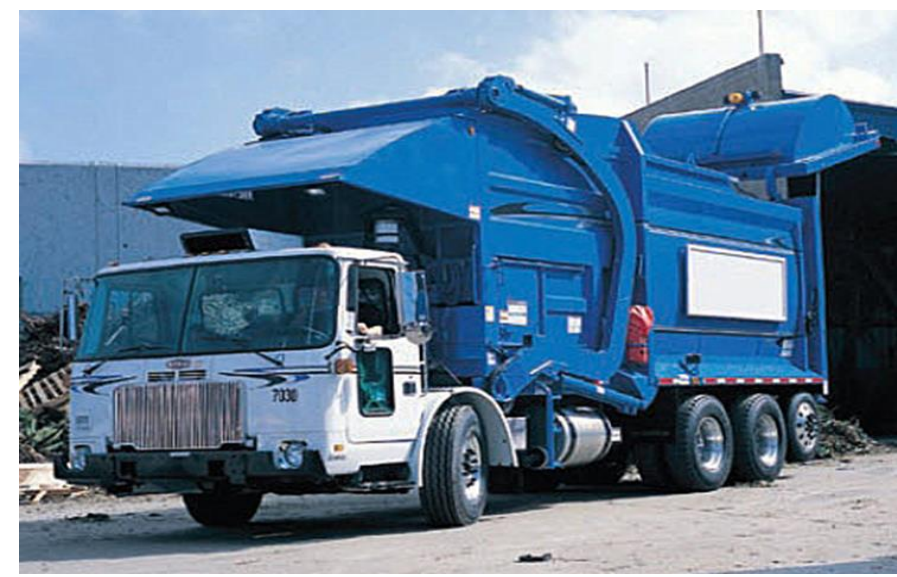

Figura 28 - Caminhão de coleta de RSU movido a biogás, Toronto, Canadá.

Fonte: Site O eco. (2011).

\section{São Francisco e Oakland, EUA}

Desde 2009, o lixo que moradores e empresas de Oakland e San Francisco, na Califórnia, depositam no aterro sanitário de Altamont é transformado em GNL - Gás Natural Liquefeito. O combustível está sendo usado por caminhões de lixo em substituição ao diesel.

Trata-se da maior usina mundial de GNL que tem o lixo como matéria prima, com produção de 50 mil litros diários de gás e capacidade de retirar do meio ambiente 30 mil toneladas por ano de $\mathrm{CO}_{2}$ /ano.

\section{GNV, Madrid, Espanha}

A cidade de Madrid, na Espanha, já conta com uma frota de 445 caminhões de coleta movidos a gás natural como pode ser visto na figura 29. 


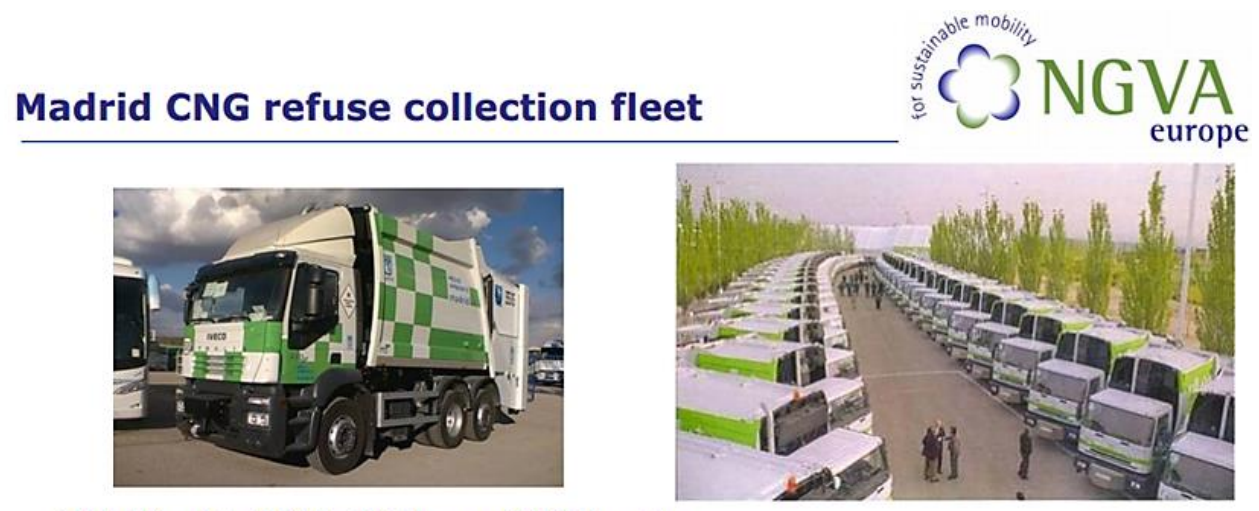

Total fleet in 2006: 445 Iveco CNG trucks Yearly gas consumption: $10.500 .000 \mathrm{Nm} 3$

Figura 29 - Frota de caminhões movidos a GNV. Fonte: NGVA europeu (2011).

\section{Chesapeake, Virginia, EUA}

Chesapeake inaugurou a primeira frota capaz de trabalhar em veículos movidos a gás natural, caminhões de coleta de RSU. Atualmente, existem seis veículos movidos com GNV em atividade. fornecendo serviço de coleta seletiva além de Chesapeake, também em Virginia Beach e Suffolk. A operação de coleta deverá deixar de consumir 60.000 litros de diesel anualmente. (USEPA. 2011). A figura 30 mostra o modelo do caminhão utilizado na frota.

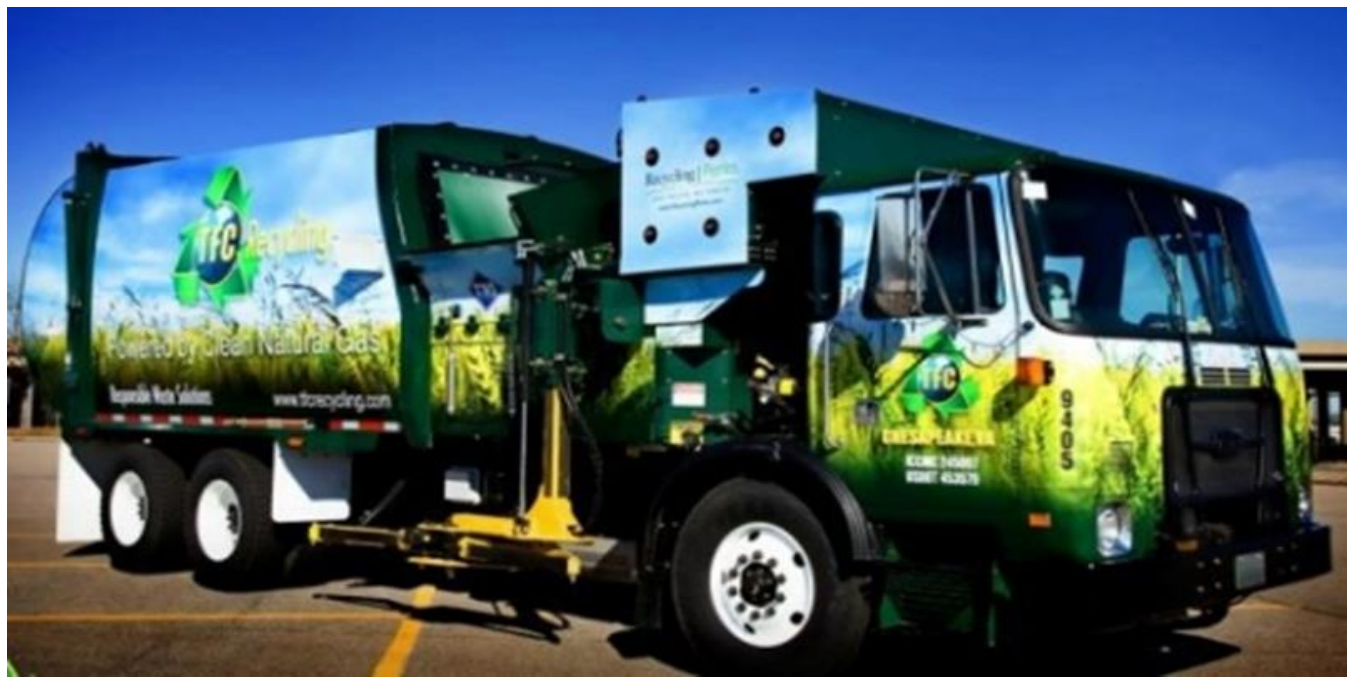

Figura 30 - Caminhão de coleta de RSU movido a GNV, Chesapeake, Virginia, EUA. Fonte: NGV JOURNAL (2011). 


\section{Los Angeles, EUA, diesel/biogás (híbrido)}

A cidade de Los Angeles tomou a decisão de adquirir caminhões de lixo Dual-Fuel (híbridos) de gás natural (GNL) liquefeito e diesel. Em 1999, o departamento de saneamento realizou um estudo de campo com caminhões de lixo equipados com vários tipos de motores de combustível alternativo, incluindo gás natural comprimido, GNC, e GNL e Dual-Fuel. O estudo mostrou que os caminhões que transitam com motores híbridos foram os mais adequados para cumprir os requisitos operacionais da coleta de lixo. Especificamente, os caminhões Dual-Fuel possuem torque e potência suficientes e podem ser operados com segurança em todos os terrenos abrangidos pelo serviço de coleta. A Agência de controle de poluição de ar para a Califórnia admite que a exposição às emissões provenientes da queima de diesel são cancerígenas e recomendou suspender a aquisição de veículos movidos a diesel.

À plena carga, até $95 \%$ da energia de funcionamento do motor desses veículos é fornecida por gás natural, com os restantes $5 \%$ por diesel. Os motores usam uma técnica para aumentar a proporção de gás natural e reduzir as emissões com cargas leves.

\section{Porto Alegre, RS, Brasil}

Em Porto Alegre, está sendo testado o primeiro caminhão de lixo movido agás natural veicular para aplicação em coleta de lixo no Brasil. O veículo tem 16 toneladas de Peso Bruto Total (PBT) e é equipado com um motor Iveco-FPT NEF 6 , de seis cilindros. A capacidade de armazenamento é de $126 \mathrm{~m}^{3}$ de gás, como está apresentada na figura 31 , e tem uma autonomia de $350 \mathrm{Km}$. Os testes fazem parte de um projeto de desenvolvimento do mercado de gás natural veicular para veículos pesados.

O acordo também envolve a PUC/RS, que irá monitorar as emissões de poluentes na atmosfera e o desempenho do caminhão nas rotas de coleta, além de ser responsável pela metodologia utilizada para o tratamento de dados. Após seis meses de testes, será feito um estudo sobre os impactos positivos da conversão de toda a frota de veículos de coleta de lixo na capital para caminhões GNV. 


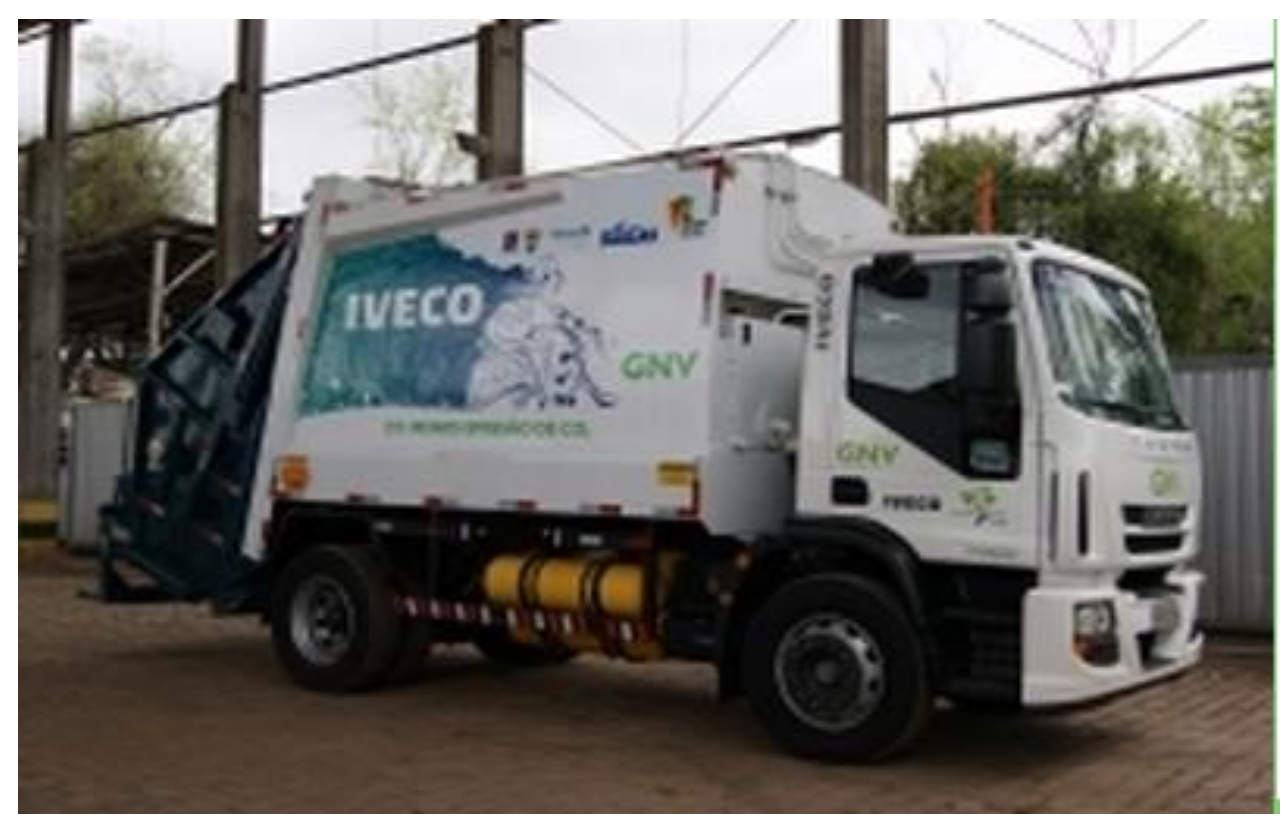

Figura 31 - Caminhão movido a gás / Porto Alegre, Brasil.

Fonte: Silas Colombo, Portal Transporta Brasil (2012).

\section{Antuérpia, Bruxelas, Bélgica. Diesel/Elétrico (Híbrido)}

O protótipo de um caminhão pesado híbrido, batizado de Metrópolis pode circular em zonas ambientalmente sensíveis sem emissões e quase sem ruído. As baterias de íons de lítio, localizadas atrás da cabine, para não roubar espaço da carroceria e otimizar a distribuição de peso, podem ser alimentadas por uma tomada elétrica. Um motor diesel funciona como gerador de bordo e como extensor de autonomia.

O veículo tem um motor elétrico que produz cerca de $203 \mathrm{~kW}$ e aciona o eixo traseiro através de uma caixa automática de duas velocidades. As unidades auxiliares, como direção assistida, compressor de ar, bomba hidráulica e sistema de ar-condicionado também são operadas por um sistema de gestão de energia. Um monitor na cabine transmite informações ao motorista sobre os parâmetros de energia, tais como recuperação de energia, estado da bateria e modo de carga. $\mathrm{O}$ carregamento das baterias é mostrado na figura 32 . 


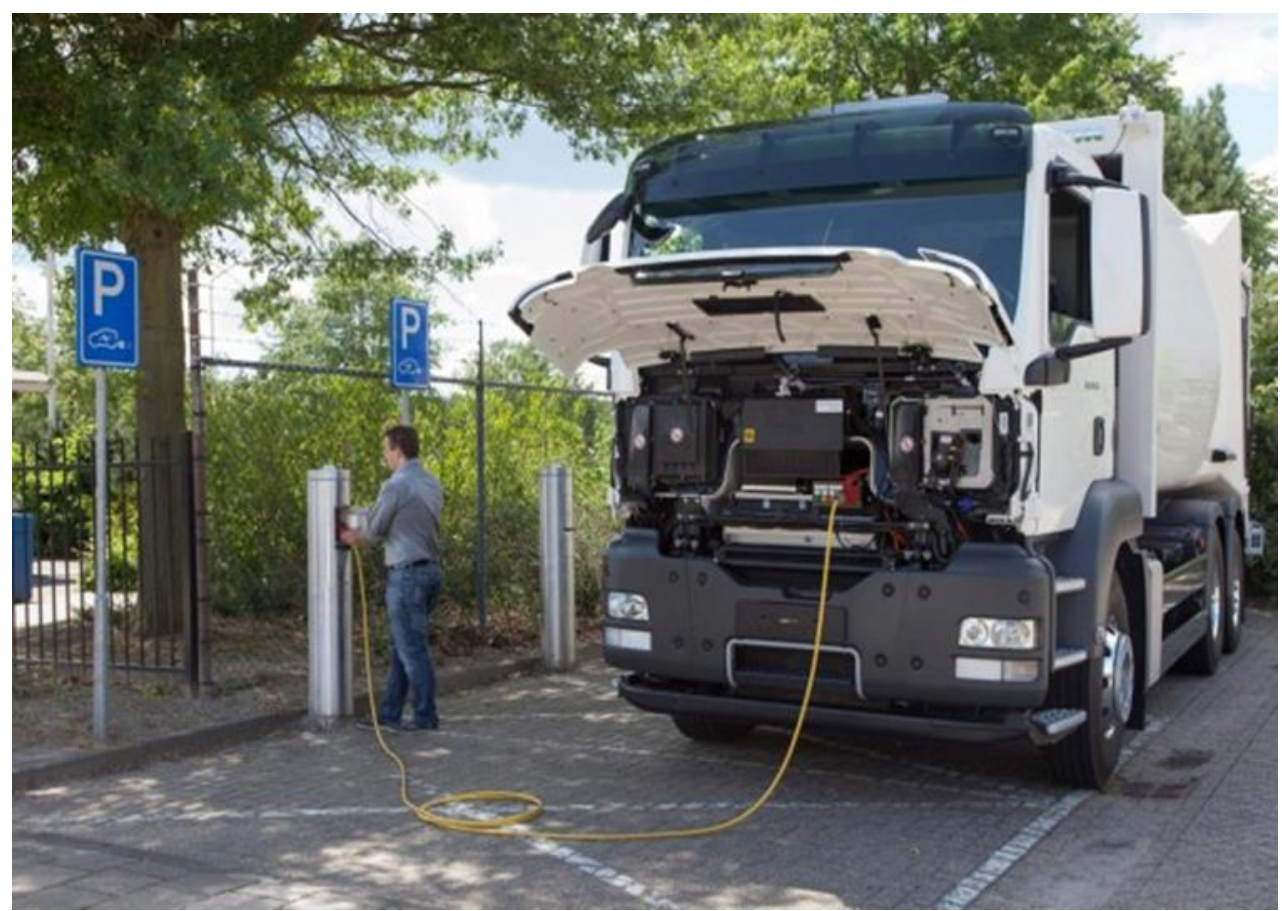

Figura 32 - Abastecimento caminhão hibrido com energia elétrica.

Fonte: Blog do caminhoneiro, 2012.

A energia é fornecida por baterias modulares de íons de lítio com uma capacidade máxima de 105 kWh. Graças à função "Plug-in", as baterias podem ser recarregadas num ponto de abastecimento. As baterias foram instaladas atrás da cabina, por cima do eixo dianteiro, onde é instalado tradicionalmente um motor diesel num caminhão convencional. O peso da bateria fica assim no eixo dianteiro permitindo que o eixo traseiro possa suportar a carroceria e a carga. A redução de peso alcançada pela eliminação do motor convencional de caminhão e da caixa de velocidades é neutralizada pelo peso do sistema híbrido. A função de extensor de autonomia é assegurada pelo motor diesel V6 TDI 3.0 com 204 cv de potência. Um programa de gestão eletrônica do motor procura que o motor diesel funcione sempre da forma mais eficiente em termos de consumo.

O veículo irá operar em serviço experimental, durante dois anos, na coleta de resíduos urbanos na Bélgica, mais concretamente na região de Antuérpia Bruxelas. O veículo receberá uma carroceria, com um sistema hidráulico de carregamento dos contêineres de lixo concebido especialmente para uma operação totalmente elétrica. 
Em modo de baixo ruído, o caminhão funciona apenas com motor elétrico, sendo realizado de forma elétrico-hidráulica o acionamento para elevação do contentor de lixo e compressão dos resíduos.

A operação elétrica foi concebida para um turno diário, compreendendo dois ciclos de quatro horas de coleta de resíduos.

\section{Courbevoie, França, Elétrico}

Uma frota de 11 caminhões totalmente elétricos começou a operar diariamente na vila de Courbevoie, nos arredores de Paris, no final de 2011. Com capacidade para coleta de 26 toneladas de RSU, livre de emissões e ruídos e desempenho similar ao dos caminhões alimentados por combustível fóssil, têm ainda a vantagem de poluir muito menos. São equipados com baterias de íon-lítiopolímero moduláveis e intercambiáveis, comportando recarga parcial entre duas jornadas de serviço diário. Alcançam a velocidade máxima de $70 \mathrm{Km} / \mathrm{h}$, com carga plena, e o benefício adicional de $100 \%$ de torque de partida. Os caminhões de coleta de resíduos totalmente elétricos têm capacidade para coletar 16 toneladas em duas rodadas do serviço. Graças à cinemática da caixa de velocidades, o caminhão será capaz de subir aclives íngremes (até 23\%), com carga completa, sem perturbar o tráfego urbano. Cada veículo é equipado com um sistema de bateria completo, contendo cinco sequências de caracteres de sete pacotes de bateria (equivalentes a 250 quilowatts-hora), capacidade de gestão de alimentação e o sistema de gerenciamento de bateria completa, plano-célula de bateria por causa de sua vida útil de 10 anos e a densidade superior de energia/hora 170 watts por quilograma de energia específica. A autonomia estimada entre $150-200 \mathrm{Km}$, sem necessitar de recarga.

Os veículos podem ser usados, em diversas operações sob temperaturas muito diferentes. As baterias trazem a confiabilidade de mais de 10 anos de desempenho comprovado em simulações exigentes. Todos os elementos do conjunto propulsor dos caminhões são elétricos e mecânicos os de recolhimento de contêineres de lixo, com significativa a redução da poluição sonora. Estes caminhões de emissão zero vão permitir uma economia de 130 toneladas de $\mathrm{CO}_{2}$ por veículo, por ano. O caminhão elétrico pode ser visualizado na figura 33. (PVI, 2012). 


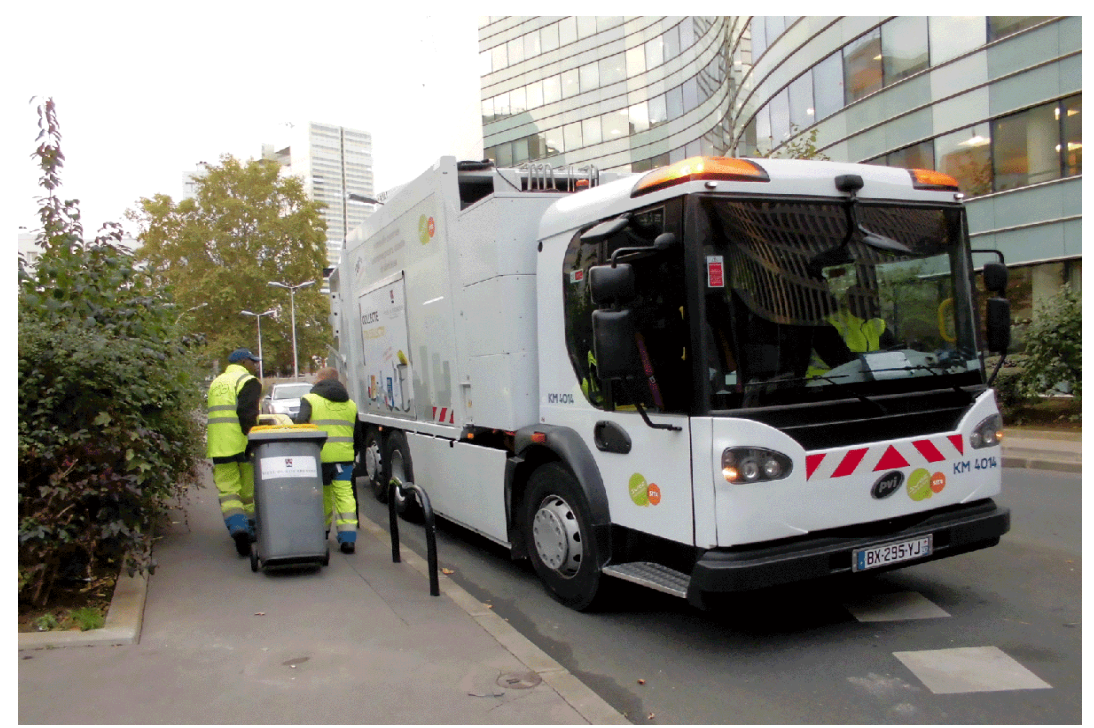

Figura 33 - Caminhão elétrico (França). Fonte: PVI, 2012.

\section{Lixo Subterrâneo (coleta pneumática)}

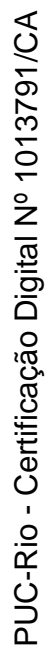

Bonfiglioli (2011) escreveu um artigo no jornal "O Estado de São Paulo", que a cidade de Barcelona( Espanha) foi pioneira em estabelecer um sistema de coleta de lixo subterrâneo, a partir de tubulações e bombas de sucção que retiram os resíduos sólidos das ruas e dos prédios residenciais. Esse sistema de coleta pneumática é chamado de "Envac". A figura 34 exemplica como funciona essa coleta. 


\section{LIXO SUBTERRÂNEO}

10 sistema recebe três tipos de lixo, que podem estar em lugares públicos ou residenciais (prédios e condomínios), formando uma malha de canais subterrânea com $113 \mathrm{~km}$
2 Uma central computadorizada identifica quando o reservatório enche, abrindo uma válvula para tubulações maiores. O sistema também abre de hora a hora. Cada tipo de lixo é enviado por vez, para evitar que se misturem

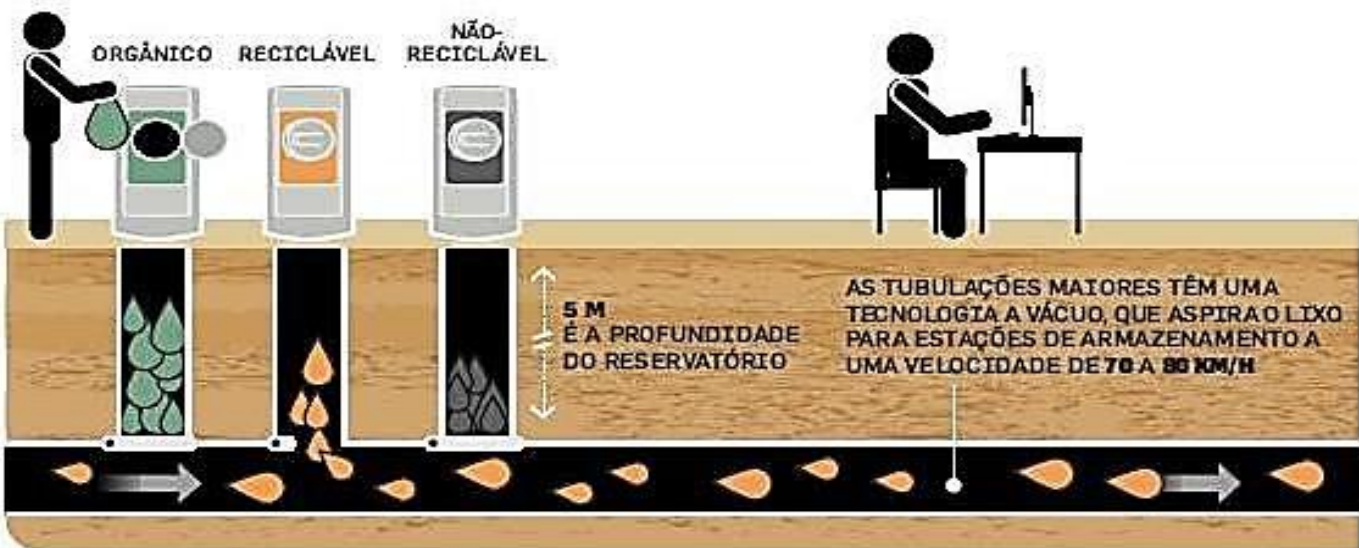

3 Nas estações, cada tipo de lixo é contêineres diferentes

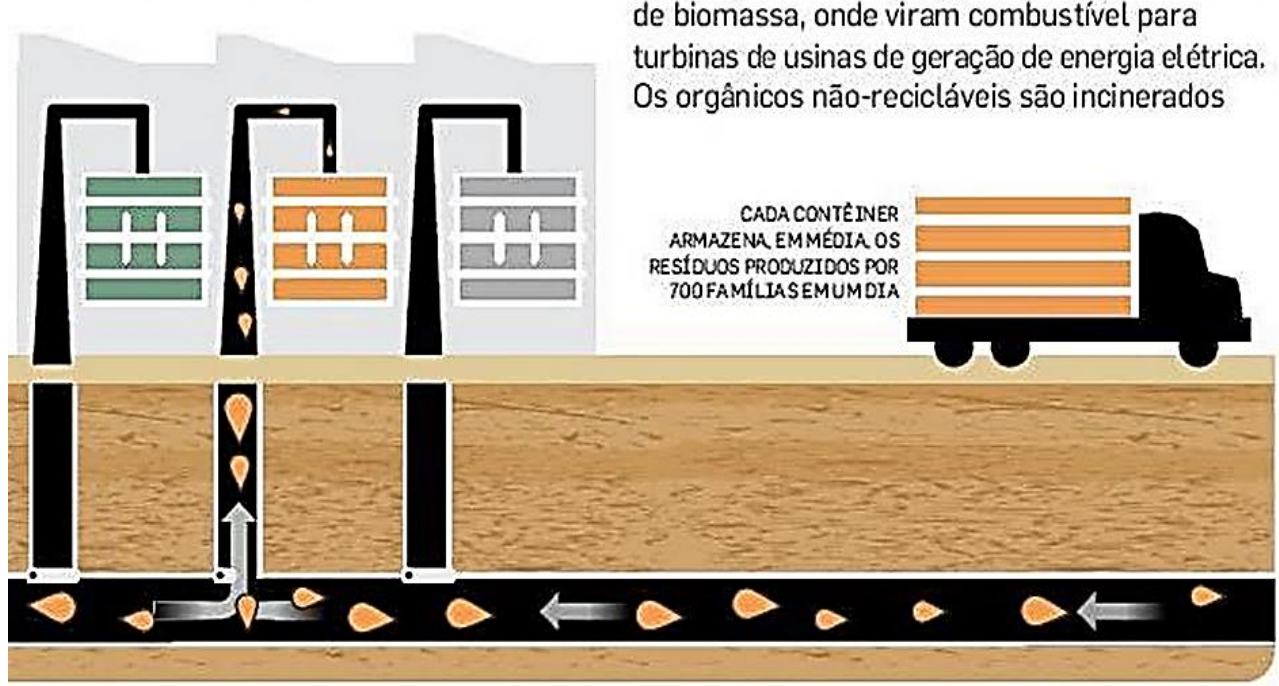

Cada contêiner é levado para um lugar específico. Recicláveis vão para estaçōes de reciclagem, resíduos orgânicos vão para usinas de biomassa, onde viram combustível para turbinas de usinas de geração de energia elétrica. Os orgânicos não-recicláveis são incinerados

INFOSRUFICOAEE

Figura 34 - Esquema de coleta pneumática de resíduo Barcelona. Espanha. Fonte: BONFIGLIOLI, jornal O Estado de São Paulo (2011). 
Separados por escotilhas com cores diferentes relativas a cada matéria, as bocas do lixo estão presentes em várias áreas da cidade e em prédios. Dependem dos moradores para que estes coloquem em cada uma dessas escotilhas o resíduo específico.

Por meio de um sistema informatizado, a cada uma hora as bombas de sucção são ativadas e, a uma velocidade superior a $70 \mathrm{Km} / \mathrm{h}$, fazem com que os resíduos atravessem os $113 \mathrm{Km}$ de tubulações instalados a uma profundidade de 5 m, por toda a cidade.

Esses resíduos chegam já separados até a unidade coletora. Lá, entram diretamente em contêineres que, depois de cheios, são direcionados às usinas de papel, plástico e metal.

Quanto ao lixo orgânico, há o aproveitamento de biomassa como matéria prima para a geração de energia elétrica.

Tal sistema evita a circulação de caminhões pelo centro da cidade, que tem ruelas estreitas que dificultam esse trânsito. Os caminhões somente são utilizados para a coleta do lixo disposto em caçambas que ficam normalmente perto das áreas de comércio e na região dos portos.

Apesar de ter um alto custo operacional, evita odores, acúmulo de lixo e melhora o tráfego. Além das vantagens ambientais, o sistema proporciona um melhor aproveitamento do espaço urbano, até mesmo visualmente, já que não mais existe a cena dos sacos de lixo na porta das casas e estabelecimentos comerciais. Hoje a cidade tem $30 \%$ do lixo coletado em oito pontos.

A instalação da Envac tem quatro grandes turbinas que evitam obstruções na tubulação. Quando ocorrem, os problemas são logo identificados por uma central computadorizada que monitora todos os trajetos. No caso de entupimento, turbinas são acionadas. Com o ganho de poder de sucção, em $90 \%$ dos casos, o cano é desobstruído. Nas demais emergências, o problema é resolvido manualmente.

O sistema é eficiente, mas não barato. Já foram investidos 156 milhões de euros em Barcelona. A instalação de uma rede capaz de atender a 18 mil famílias custa, em média, 50 milhões de euros. Fonte: Estado de São Paulo (2011). 


\section{TRATAMENTOS DOS RSU}

\section{1}

\section{Alternativas de tratamento dos resíduos}

Define-se tratamento como uma série de procedimentos destinados a reduzir a quantidade ou o potencial poluidor dos resíduos sólidos, seja impedindo descarte de lixo em ambiente ou local inadequado, seja transformando-o em material inerte ou biologicamente estável. (MONTEIRO, 2001).

O conhecimento e a compreensão das etapas de execução dos serviços de limpeza urbana (coleta e transporte dos resíduos, tratamento e disposição final) e as tecnologias existentes para cada fase do gerenciamento dos RSU serão determinantes na escolha do modelo operacional de tratamento a ser implantado (PRICEWATERHOUSECOOPERS, 2011). A tabela 15 apresenta uma estimativa da quantidade de RSU destinados a diferentes formas de tratamento e disposição final no Brasil.

Tabela 15 - Quantidade diária de resíduos sólidos domiciliares e/ou públicos encaminhados para diferentes formas de destinação final (2000 a 2008).

\begin{tabular}{|lcccc|}
\hline \multicolumn{1}{|c}{ Destino Final } & $\begin{array}{c}2000 \\
\text { Quantidade } \\
\text { (t/d) }\end{array}$ & $\%$ & $\begin{array}{c}\text { Quantidade } \\
\text { (t/d) }\end{array}$ & $\%$ \\
Aterro sanitário & $49.614,50$ & 35,4 & $110.044,40$ & 58,3 \\
Aterro Controlado & $33.854,30$ & 24,2 & $36.673,20$ & 19,4 \\
Vazadouros a céu aberto (Lixão) & $45.484,70$ & 32,5 & $37.360,80$ & 19,8 \\
Unidade de compostagem & $6.364,50$ & 4,5 & $1.519,50$ & 0,8 \\
Unidade de triagem para reciclagem & $2.158,10$ & 1,5 & $2.592,00$ & 1,4 \\
Unidade de incineração & 483,10 & 0,3 & 64,80 & $<0,1$ \\
Vazadouro em áreas alagáveis & 228,10 & 0,2 & 35,00 & $<0,1$ \\
Locais não fixos & 877.30 & 0,6 & SI & \\
Outra unidade & $1.015,10$ & 0,7 & 525,20 & 0,3 \\
Total & $140.080,70$ & & $188.814,90$ & \\
\hline Si: sem informação. Na PNSB 2008 não se utilizou cs:a opfão como destino final & & \\
\hline
\end{tabular}




\section{2}

\section{Reciclagem}

A reciclagem é um processo industrial que permite a separação e transformação dos resíduos sólidos do lixo urbano. Os RSU podem e devem ser reaproveitados. A reciclagem dos materiais recuperáveis nele encontrados tem cada vez maior aceitação no mundo. As vantagens econômicas, sociais, sanitárias e ambientais sobre os outros métodos são evidentes. Este processo constitui importante forma de recuperação energética, especialmente quando associado a um sistema de compostagem. (HENRIQUES).

O reaproveitamento dos resíduos expande o ciclo de vida das reservas de matéria prima e energia na medida em que reduz a demanda por esses recursos, tendo em vista que obriga seu uso mais eficiente. Apenas alguns componentes do lixo urbano não podem ser reaproveitados. É o caso de louças, pedras e restos de aparelhos sanitários, que até o momento, pelo menos, não têm nenhum aproveitamento econômico.

Dependendo das características regionais, a reciclagem pode representar um fator importante de redução de custos do sistema de limpeza urbana. Isto porque possibilita enorme diminuição da quantidade de material a ser disposto no aterro sanitário, ampliando a vida útil deste.

Para Henriques, a necessidade de poupar e preservar os recursos naturais não renováveis vem motivando cada vez mais o reaproveitamento de resíduos, visto que crescem exponencialmente a população e o consumo, o que não acontece com as reservas naturais.

A reciclagem se vale do sistema de separação pré-coleta, onde os resíduos não chegam a ser misturados nos locais de sua produção. É preciso garantir que os resíduos cheguem à usina de reciclagem em bom estado. Isso significa que o lixo seco não deve entrar em contato com os restos orgânicos. Um copo de café jogado numa lata de lixo compromete a reciclagem de todo o papel ali contido.

O material que se encontra misturado no lixo domiciliar pode ser separado em uma usina de reciclagem através de processos manuais e eletromecânicos, em geral com uma eficiência de apenas 3 a $6 \%$ em peso, dependendo do tamanho e do grau de sofisticação tecnológica da usina. 
De qualquer forma, o material reciclável que é separado, geralmente é sujo, com terra, gordura e vários outros tipos de contaminantes. Por isso o beneficiamento correto desse material pelas indústrias é muito caro e bem mais complicado.

É necessário implantar toda uma infra-estrutura e criar mercados para manejar, processar, vender e utilizar os materiais recuperados. Todos os aspectos dessa atividade precisam ser desenvolvidos em conjunto. Não é producente ou útil recuperar materiais para os quais não haja mercado ou demanda. O tamanho do mercado e a quantidade de materiais recuperáveis ou reutilizáveis afetarão a viabilidade de qualquer programa. (BANCO MUNDIAL, 2004).

A reciclagem ideal é aquela proporcionada pela população que separa os resíduos recicláveis em casa.

O êxito da coleta seletiva para reciclagem favorece ainda a transformação sobretudo em combustíveis, da biomassa presente nos restos alimentares.

Recuperar materiais traz benefícios como:

- Redução de custos com a disposição final do lixo, por consequência de volume reduzido.

- Aumento da vida útil dos aterros sanitários.

- Diminuição de gastos com remediação de áreas degradadas pela má destinação do lixo (lixões clandestinos).

- Diminuição de gastos gerais com limpeza pública a médio e longo prazo.

- Agrega valor ao resíduo.

- Melhoria das condições ambientais e de saúde pública do município e preservação dos recursos naturais.

- Geração de renda e emprego.

- Expansão da vida útil das matérias primas.

Em países desenvolvidos, a recuperação de materiais foi instituída por políticas ambientais, despertando, na sociedade, o interesse para a problemática dos resíduos sólidos. (PRICEWATERHOUSECOOPERS, 2011). No gráfico a seguir, algumas taxas de reciclagem no gráfico a seguir (Figura 35): 


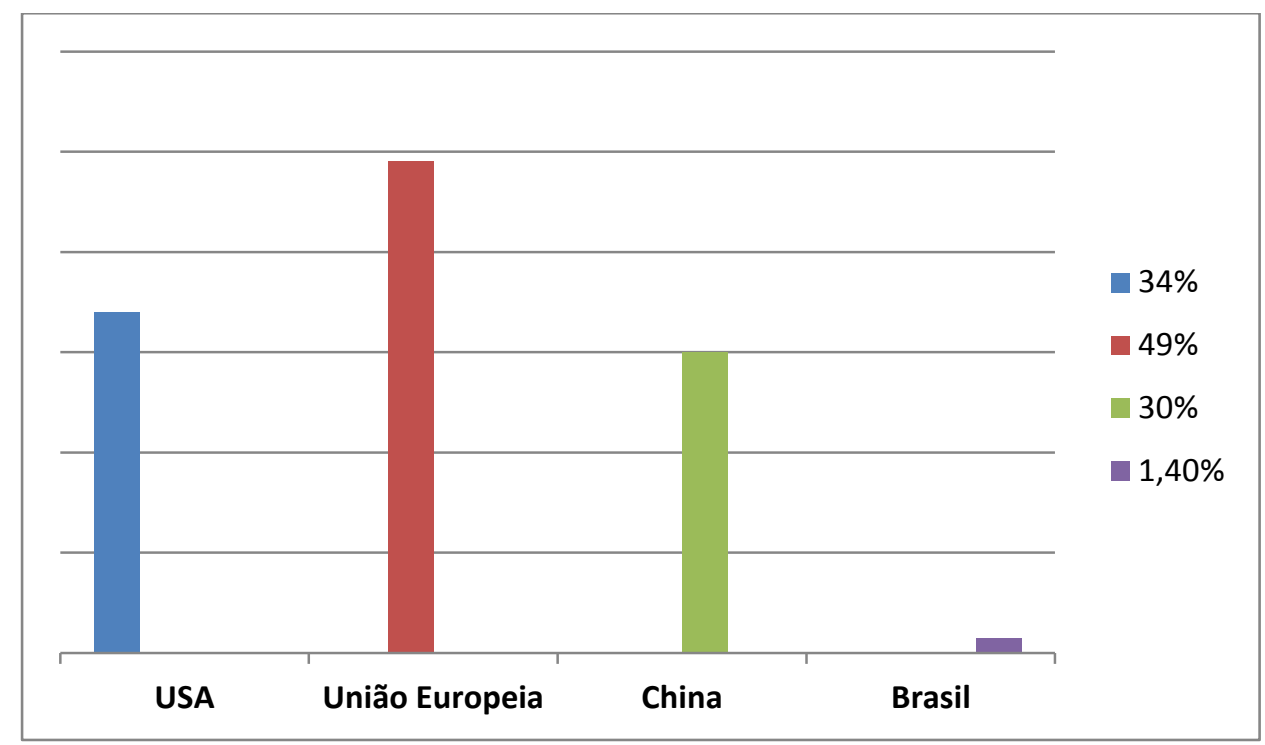

Figura 35 - Gráfico comparativo entre Taxas de Reciclagem.

Fonte: ABRELPE, 2011.

Os cinco municípios brasileiros onde a prefeitura faz chegar o serviço de coleta seletiva a 100\% das residências são Curitiba (PR), Itabira (MG), Londrina (PR), Santo André (SP) e Santos (SP). Em Curitiba, por exemplo, a fórmula que deu certo inclui o uso de caminhões que recolhem apenas o lixo seco, sem nenhum resto orgânico. O resultado: o lixo fica mais limpo e acaba vendido por um preço mais alto às indústrias de reciclagem. Isso ajuda a tornar o sistema de coleta seletiva em Curitiba mais barato (e viável) que o da maioria das cidades brasileiras. (VEJA, 2012).

A cidade do Rio de Janeiro recicla apenas 3\% de seu lixo, $0.27 \%$ através da COMLURB, e o resto 2,73\% feito por catadores autônomos e cooperativas. As taxas das cidades europeias em média são em média, superiores a 40\%.

Uma parte dos materiais recicláveis, como o papel, por exemplo, ao ser encaminhada para os aterros, gera o biogás. Portanto, quando reciclada evita uma emissão, contabilizada na redução de emissões do município.

A reciclagem é a melhor rota energética do lixo, pois com ela a indústria economiza energia". De acordo com Bastos, cada tonelada de material reciclado gera três megawatts/hora de energia economizada, enquanto a melhor tecnologia de incineração gera energia a partir do lixo de um megawatt/hora. E o ideal seria associar a reciclagem ao uso de tecnologias como biodigestores, onde o lixo é confinado em ambiente sem oxigênio, mas com as bactérias que o digerem 
gerando adubo a partir do material orgânico e gases que podem ser aproveitados transformando-os em energia.

\section{3}

\section{Compostagem associada aos biodigestores}

Trata-se de método de decomposição do material orgânico do lixo (restos de origem animal ou vegetal), sob condições adequadas, de forma a se obter um composto orgânico estabilizado, sem ocasionar riscos ao meio ambiente, para utilização na agricultura.

Considerada um método de tratamento, a compostagem também pode ser entendida como uma das destinações finais do material orgânico presente no lixo.

Uma das alternativas para tratar a parcela orgânica, são os biodigestores. A compostagem associada a biodigestores viabiliza uma enorme redução da quantidade de material a ser disposto em aterro sanitário (somente o que for rejeitado no processamento). A qualidade final do composto é diretamente proporcional à eficiência da separação; depende da coleta seletiva dos resíduos orgânicos. Esse produto, o composto orgânico, pode ser aplicado ao solo para melhorar suas características, sem ocasionar riscos ao meio ambiente. (MMA, 2013).

O biodigestor é uma câmara na qual ocorre um processo bioquímico denominado digestão anaeróbia, que tem como resultado a formação de biofertilizantes e gazes, principalmente o Metano e o Dióxido de carbono (biogás). (MAGALHÃES, 1986).

Esta conversão do complexo orgânico requer uma mistura de espécies bacterianas. Dependendo da temperatura em que o processo acontece, o tratamento de resíduos orgânicos é basicamente de três tipos: a) a biometanação, com temperaturas entre $45-60^{\circ} \mathrm{C}$ é considerada termofílica; b) a que ocorre entre as temperaturas de $20-45^{\circ} \mathrm{C}$ é a mesofílica; c) a digestão anaeróbia de matéria orgânica em baixas temperaturas $\left(>20^{\circ} \mathrm{C}\right)$ é referida como digestão psicrofílica. (BIODIESELBR, 2011).

A conversão anaeróbia produz quantidade relativamente pequena de energia para os microrganismos, por isso, a sua velocidade de crescimento é baixa e apenas uma pequena porção do resíduo é convertida em nova biomassa celular. 
Um esquema simplificado (Figura 36), representando as etapas metabólicas, é mostrado no diagrama abaixo. (SANTOS, 2001).

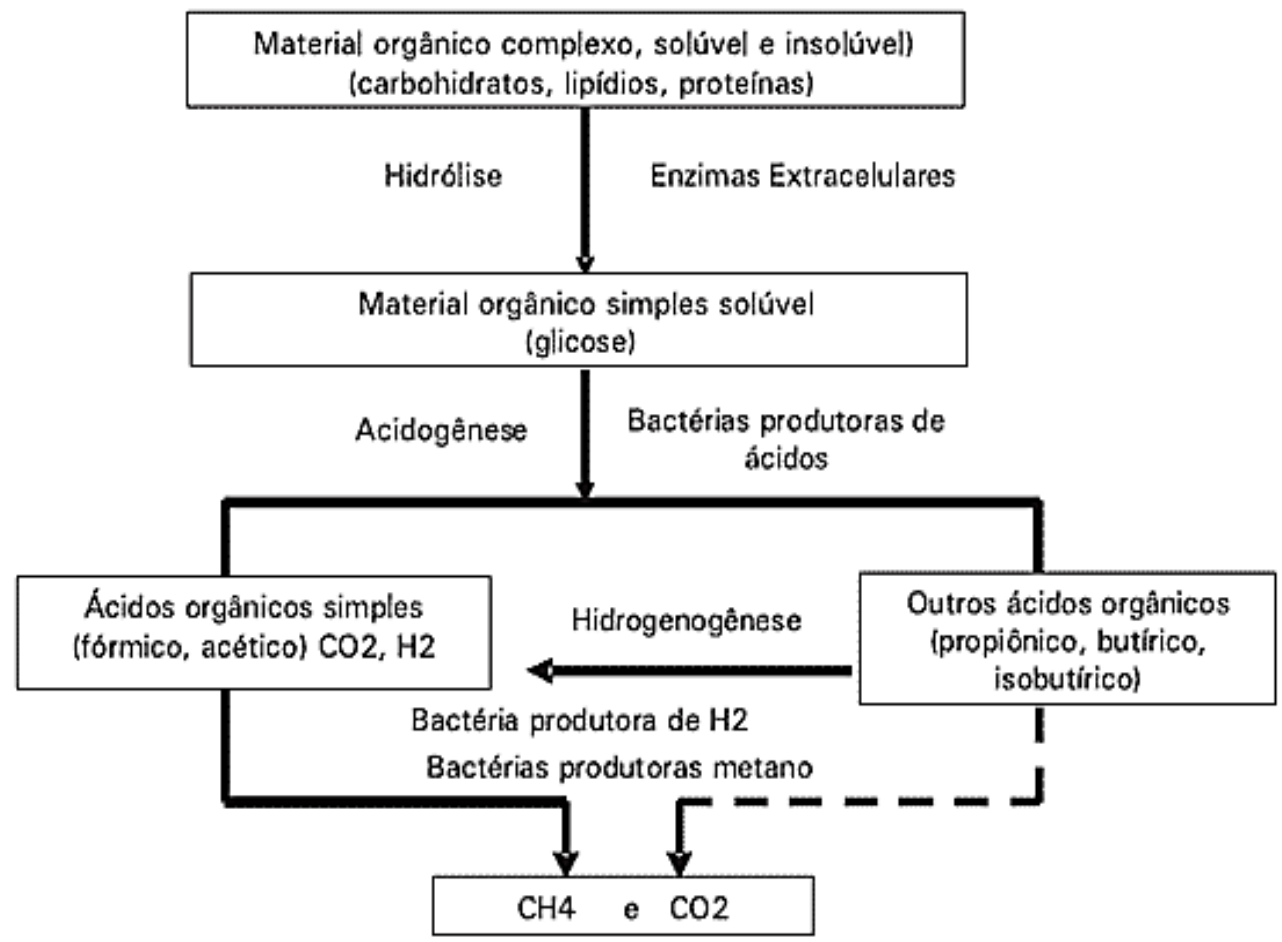

Figura 36 - Etapas metabólicas do processo de digestão anaeróbia em biodigestor.

Fonte: BIODIESELBR (2011).

O tratamento de dejetos por digestão anaeróbia, segundo Sánchez (2005), possui várias vantagens, tais como destruir organismos patogênicos e parasitas, poder usar o metano como uma fonte de energia, produção de baixa biomassa com menor volume de dejetos e menor custo, capacidade de estabilizar grandes volumes de dejetos orgânicos diluídos a baixo custo.

Os produtos da compostagem são largamente utilizados em jardins, hortas, substratos para plantas e no solo como adubo orgânico devolvendo à terra os nutrientes de que necessita, aumentando sua capacidade de retenção de água, permitindo o controle de erosão e evitando o uso de fertilizantes sintéticos. (MMA, 2013).

Atualmente, existem, no mundo, distribuídos na Europa, América do Norte e na Ásia, mais de mil empreendimentos que empregam a compostagem associada a biogestores. 


\section{Compostagem no Brasil}

No quesito tratamento, apesar da massa de RSU apresentar alto percentual de matéria orgânica, as experiências de compostagem, no Brasil, são ainda incipientes. O resíduo orgânico, por não ser coletado separado, acaba sendo encaminhado para disposição final, juntamente com os resíduos domiciliares. Essa forma de destinação gera, para a maioria dos municípios, despesas que poderiam ser evitadas caso a matéria orgânica fosse separada na fonte e encaminhada para um tratamento específico, por exemplo, via compostagem.

Do total estimado de resíduos orgânicos que são coletados $(94.335,1 \mathrm{t} / \mathrm{d})$ somente $1,6 \%(1.509 \mathrm{t} / \mathrm{d})$ são encaminhados para tratamento via compostagem. Em termos absolutos, tem-se 211 municípios brasileiros com unidades de compostagem, sendo que os Estados de Minas Gerais e Rio Grande do Sul possuem a maior concentração, 78 e 66 unidades respectivamente. (Política Nacional de Resíduos Sólidos, 2011).

\section{Compostagem no Rio de Janeiro}

No Rio de Janeiro, está prevista a produção de $15.000 \mathrm{~m}^{3} /$ ano do composto orgânico para utilização nas ações de reflorestamento e preservação das encostas do Município. (COMLURB, 2011).

\section{4 \\ Incineração}

Incineração é um processo de combustão controlada para transformar resíduos sólidos, líquidos e gases combustíveis em Dióxido de carbono, outros gases e água, reduzindo significativamente o volume e pesos iniciais.

Da incineração do lixo resulta um residual sólido constituído basicamente de materiais incombustíveis que deverão ser dispostos em aterros sanitários ou reciclados.

As cidades utilizam o processo de incineração ao terem esgotadas as possibilidades de emprego das outras soluções sanitárias tradicionais de destinação de lixo, tais como: aterro e compostagem. A incineração é um processo 
bastante caro, tanto pelo investimento a ser feito, como por sua operação e manutenção.

Os incineradores possuem a vantagem de poderem ser localizados em qualquer ponto, desde que bem projetados e operados. Não exigem grandes áreas, dão destino da forma mais segura, do ponto de vista sanitário. Os incineradores de grande porte permitem o aproveitamento da energia sob a forma de vapor, água quente e eletricidade, quando construídos para esse fim, auxiliando na redução do custo operacional do tratamento térmico.

Além desses incineradores para a queima de lixo coletado pelo município, existem no Brasil diversas unidades de menor porte instaladas em hospitais, indústrias e aeroportos.

No Brasil, os incineradores atendem somente a destruição dos lixos que representam riscos à saúde, segurança e bem estar social. O lixo brasileiro possui composição de matéria orgânica com elevado teor de umidade e baixo poder calorífico, o que torna difícil sua combustão, assim como o seu uso para produção de energia. Alguns ambientalistas dizem que as usinas de incineração necessitam de material reciclável por ele ser mais comburente, de queima mais fácil.

No Japão e nos EUA, aproximadamente $15 \%$ do volume de resíduos gerado recebem este tratamento, enquanto no Brasil, segundo o IBGE [2002], este número gira em torno de $0,5 \%$ do volume total.

Do ponto de vista sanitário é excelente. A desvantagem fica por conta dos riscos de poluição atmosférica, quando o equipamento não for adequadamente projetado e/ou operado.

\section{Incineração no Rio de Janeiro}

A Usina Verde situada na Ilha do Fundão trabalha com a incineração de lixo urbano. Considerada de tecnologia limpa, por destruir termicamente os gases poluentes produzidos no processo, libera na atmosfera apenas vapor de água e $\mathrm{CO}_{2}$, sem causar danos ambientais. Inaugurada em 2004, recebe diariamente 30 toneladas de resíduos sólidos, já pré-tratados, provenientes da Estação de Transferência da Companhia de Limpeza Urbana do município, no bairro do Caju. Na unidade, os resíduos passíveis de reutilização ou de reciclagem são retirados; o restante é incinerado. Os gases ácidos resultantes da incineração do lixo são 
lavados com água alcalinizada, ocorrendo, então, uma reação química que transforma as substâncias em sais minerais e água. (MACHADO).

\section{5}

\section{Destinação final adequada dos RSU}

Como demonstrado neste capítulo, em qualquer caso, os aterros sanitários serão sempre necessários, como destino final para os rejeitos, para a parcela resultante dos processos de tratamento e recuperação energética ou para materiais que não apresentem viabilidade de serem submetidos a tais processos como demonstra a Figura 37.

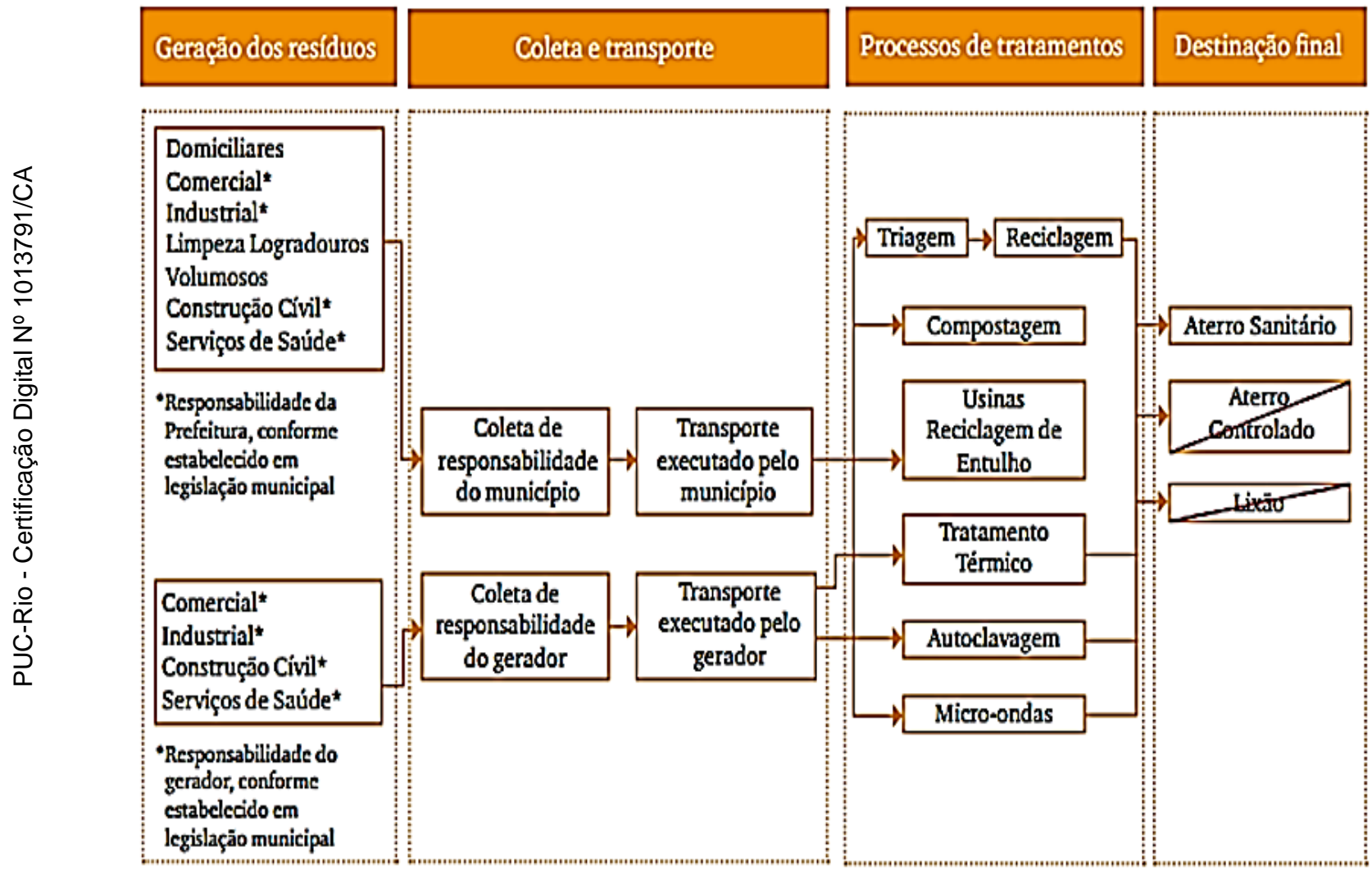

Forma insdoquada de destinsç5o finsl de acordo com a PNRS

Figura 37 - Fases do gerenciamento de resíduos sólidos do municipio.

Fonte:PwC 2011.

Note-se que tanto os aterros quanto os tratamentos térmicos podem gerar energia para ser aplicada no próprio sistema de limpeza urbana e o excedente( se houver), disponibilizado para a rede de distribuição. 


\subsection{1}

\section{Aterros sanitários: Definições e características}

O Aterro Sanitário resulta de um aprimoramento de uma das técnicas mais antigas utilizadas pelo homem para descarte de seus resíduos, que é o aterramento. Tem como função dar destinação adequada aos resíduos não compostados ou não aproveitados para reciclagem, ou ainda, receber o lixo bruto quando da inviabilidade de qualquer processo de tratamento. (CETESB, 2012).

O principio básico está na compactação dos resíduos no solo, na forma de camadas que são periodicamente cobertas com terra ou outro material inerte. Apesar de ser o método sanitário de destinação final de RSU mais simples e barato exige cuidados especiais e técnicas específicas a serem seguidas, desde a seleção e preparo da área até sua operação e monitoramento. (ENSINAS, 2003).

A crescente urbanização limita as áreas disponíveis para a disposição final dos resíduos. Grandes cidades precisam, muitas vezes, exportar seu lixo para áreas de municípios vizinhos. Em diversas outras situações, áreas não adequadas são eleitas como depósitos provisórios que, com o tempo, muitas vezes acabam se tornando permanentes. (ENSINAS, 2003).

Os tipos e as taxas de produção de resíduos sólidos no Brasil variam por causa da grande extensão territorial e das diferenças regionais, sociais e econômicas, que não permitem o estabelecimento de uma política nacional global de gerenciamento e dificultam a obtenção de dados estatísticos.

Normalmente os aterros são projetados para 20 anos ou mais. Sua vida útil depende do tamanho da área destinada à disposição de resíduos sólidos e ainda da sua cota mínima e máxima, ou seja, da altura das células, e, principalmente, da quantidade de resíduos que recebe diária, mensal e anualmente. (ICLEI, 2009). Técnicas de compactação de resíduos, associadas a processos de coleta seletiva e reciclagem podem contribuir para aumentar a sua vida útil.

Os aterros podem ser divididos em diferentes tipos:

- Aterro convencional: formação de camadas de resíduos compactados, que são sobrepostas acima do nível original do terreno resultando em configurações típicas de "escada" ou "troncos de pirâmide". 
- Aterro em valas: o uso de trincheiras ou valas visa facilitar a operação do aterramento dos resíduos e a formação das células e camadas; assim sendo, tem-se o preenchimento total da trincheira, que deve devolver ao terreno a sua topografia inicial. (CETESB, 2012).

O aterro deve operar de modo a fornecer proteção ao meio ambiente, evitando a contaminação das águas subterrâneas pelo chorume, e o acúmulo do biogás resultante da decomposição anaeróbia do lixo no interior do aterro. O biogás pode sair do interior do aterro de forma descontrolada ou infiltrar pelo solo e atingir redes de esgotos, fossas e poços rasos podendo causar explosões. (ENSINAS, 2003).

A operação de forma aleatória com deposição diária de lixo em diversas partes do aterro promove a sobreposição de camadas de lixo com idades muito diferentes, sendo o biogás resultante de uma mistura de diversas fases de degradação. Isso pode promover um aproveitamento do biogás em uma área maior do aterro no futuro, mas dificulta o aproveitamento do biogás antes do seu encerramento, pois praticamente todas as áreas continuam em operação por longos períodos.

Geralmente os aterros sanitários são compostos por células. Cada célula possui sua área e cota máxima de aterramento de lixo. Os resíduos sólidos são depositados na célula que está no momento em operação. Após o seu encerramento, cada célula é recoberta por terra (solo proveniente das escavações) e grama. Na maioria dos aterros, as células são operadas uma de cada vez. O lixo depositado é aterrado compactado e, ao final de cada jornada, é recoberto por camada de solo para evitar a exalação de maus odores e a presença de vetores, como ratos e insetos.

Além da operação, o aterro deve contar com unidades de apoio, como acessos internos que permitam a interligação entre os diversos pontos do local, São necessárias cercas, portões e guaritas para controlar a entrada de pessoas e resíduos não permitidos e evitar a entrada de animais; auxiliam a regular o fluxo de caminhões de lixo e garantem o isolamento da área para manutenção da ordem e do bom andamento das operações. (CETESB, 2012).

Os tipos de resíduos que podem ser dispostos nos aterros sanitários são aqueles considerados não perigosos, ou seja, resíduos Classe II A (por exemplo, 
matéria orgânica e papel), Classe II B (por exemplo, rochas, tijolos, vidros e certos plásticos e borrachas), regulamentados pela NBR $\mathrm{n}^{\circ} 10.004 / 04$, e resíduos de saúde do grupo A, com risco biológico. Já os resíduos da construção civil são considerados Classe II B e servem de cobertura e melhoria dos acessos do aterro sanitário, o que aumenta a vida útil dos aterros. (PRICEWATERHOUSECOOPERS, 2011).

Os resíduos de saúde do grupo B (com riscos químicos) e os resíduos industriais classificados como resíduos perigosos (Classe I) devem ser dispostos em aterros Classe I, projetados para receber somente esse tipo de resíduo.

Os resíduos de saúde do grupo A devem passar por tratamento prévio de esterilização e desinfecção (autoclave e micro-ondas, por exemplo) ou incineração, antes de serem dispostos em aterro, para garantir a segurança dos operadores e a diminuição dos riscos de contaminação no meio ambiente. Caso esses resíduos não sejam submetidos a um desses tratamentos, devem ser dispostos em células especiais e independentes, separados dos demais resíduos e não podem sofrer compactação. A Tabela 16 apresenta a relação entre os tipos de resíduos a serem dispostos e os tipos de aterros que podem recebê-los.

Tabela 16 - Tipos de aterros sanitários.

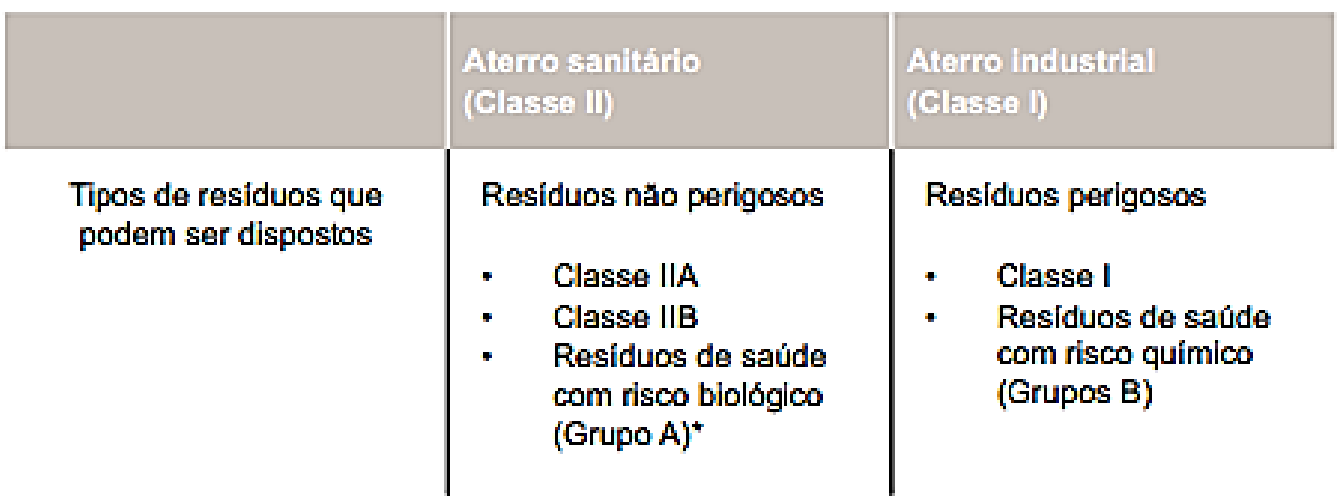

- Previamente trotados

Fonte: PRICEWATERHOUSECOOPERS 2011.

Os aterros sanitários são caracterizados por apresentarem diversos critérios de controle e monitoramento ambientais, como: 
Impermeabilização da base do aterro: evita o contato do chorume com as águas subterrâneas. Pode ser feita com argila ou geomembranas sintéticas; a impermeabilização eficiente da base e da cobertura possibilita condições adequadas para a degradação da matéria orgânica, aumentando consequentemente a produção do biogás.

Sistema de coleta de chorume: A coleta deve ser feita pela base do aterro. O chorume coletado é enviado a lagoas previamente preparadas com impermeabilização do seu contorno.

Sistema de tratamento de chorume: Após coletado, o chorume deve ser tratado antes de ser descartado no curso de um rio ou em uma lagoa. $\mathrm{O}$ tratamento pode ser feito no próprio local ou o chorume coletado pode ser transportado para um local apropriado (geralmente uma Estação de Tratamento de Esgotos). Os tipos de tratamento mais convencionais são o tratamento biológico (lagoas anaeróbias, aeróbias e lagoas de estabilização), tratamento por oxidação (evaporação e queima) ou tratamento químico (adição de substâncias químicas ao chorume). Normalmente, o chorume é captado do interior do aterro por meio de tubulações e encaminhado a tanques especiais, onde fica armazenado. Na maioria dos casos, o chorume armazenado é encaminhado para a $\mathrm{ETE}^{5}$ mais próxima do aterro, minimizando o custo de transporte.

A fim de obter ainda mais economia com o transporte e também redução de gastos com o tratamento, sugere-se a implementação de um sistema de tratamento de chorume por evaporação, no próprio aterro, utilizando o biogás como combustível. (cogeração).

\section{Evaporador de chorume}

Um dos sistemas utilizados para tratar o chorume é o processo de evaporação. Este processo permite uma redução de até $70 \%$ do volume de lixiviado. A figura 38 exemplifica como o tratamento é realizado em equipamento denominado Evaporador, onde o chorume é aquecido a altas temperaturas.

\footnotetext{
${ }^{5}$ Estação de Tratamento de Esgoto.
} 


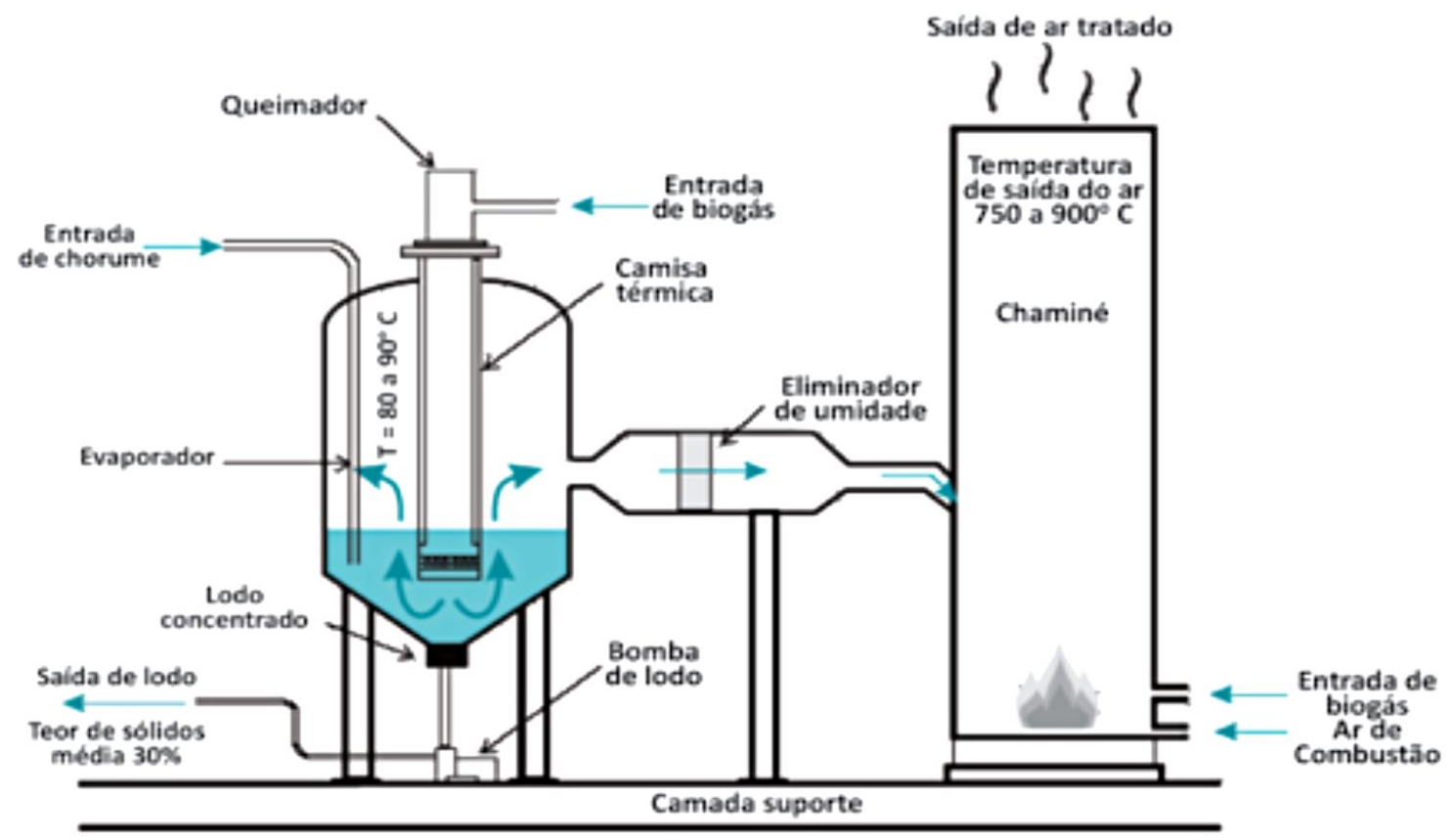

Figura 38 - Esquema de um evaporador de chorume. Fonte: MONTEIRO, 2001.

\section{Princípio de funcionamento}

O processo de aquecimento é realizado a partir da utilização do biogás como combustível. A fração líquida é evaporada, concentrando o teor de sólidos do chorume. O vapor quente passa por sistema de purificação para que possa ser lançado à atmosfera ou, então, para ser utilizado na geração de energia térmica de processo, como aquecimento ou refrigeração. O lodo adensado pode retornar para o aterro. Esta tecnologia já é empregada nos Estados Unidos, Europa e Brasil. (BAHÉ et. al., 2007).

Este tipo de processo pode ser implantado em qualquer aterro sanitário, independente do porte do aterro e da quantidade de chorume produzido. Os evaporadores de chorume geralmente são divididos em módulos. Cada módulo possui capacidade para evaporar cerca de $0,5 \mathrm{~m}^{3} / \mathrm{h}$ de chorume ou $12,5 \mathrm{~m}^{3} / \mathrm{dia}$. O consumo de biogás é da ordem de $100 \mathrm{~m}^{3} / \mathrm{h}$ para cada módulo.

Portanto, dependendo da quantidade de biogás produzido no aterro sanitário e quantidade de chorume a ser tratado, este sistema pode não ser viável. Caso o aterro não produza essa quantidade de chorume, este pode ser armazenado em um tanque e, quando atingir o volume ideal, ser enviado ao sistema de tratamento por evaporação. 


\section{Vantagens}

- Utilização do biogás como combustível (combustível de baixo custo);

- Tratamento do chorume no próprio aterro, diminuindo assim os gastos referentes ao transporte e tratamento do chorume em ETEs;

- Possibilidade de comercialização dos créditos de carbono

\section{Desvantagens}

- Necessidade de tratamento dos vapores antes do lançamento na atmosfera;

- Elevado consumo de biogás.

Sistema de drenagem de águas pluviais: o sistema de captação e drenagem de águas de chuva visa escorrer a água por locais apropriados para evitar a infiltração que gera o chorume. (CETESB, 2012).

Sistema para extração e tratamento do biogás do aterro: Usualmente, para grandes aterros, costuma-se planejar a implantação do sistema de extração em fases, que atinja todas as camadas do lixo, ampliando as instalações conforme o aumento da geração de biogás, de forma a reduzir o investimento inicial.

O sistema de extração é composto basicamente por drenos horizontais e verticais, sopradores, filtros para a remoção de material particulado e tanques separadores de condensado. Este pré-tratamento do biogás para a remoção de particulados e líquidos tem a finalidade de proteger os sopradores, aumentando a vida útil dos mesmos.

Os drenos existentes na grande maioria dos aterros sanitários brasileiros (figuras 39 e 40) e que apresentam boa vazão de biogás poderão ser adaptados e integrados ao sistema de captação. A adaptação consiste na impermeabilização da parte superior dos drenos, instalação de um cabeçote e interligação ao sistema de coleta. 


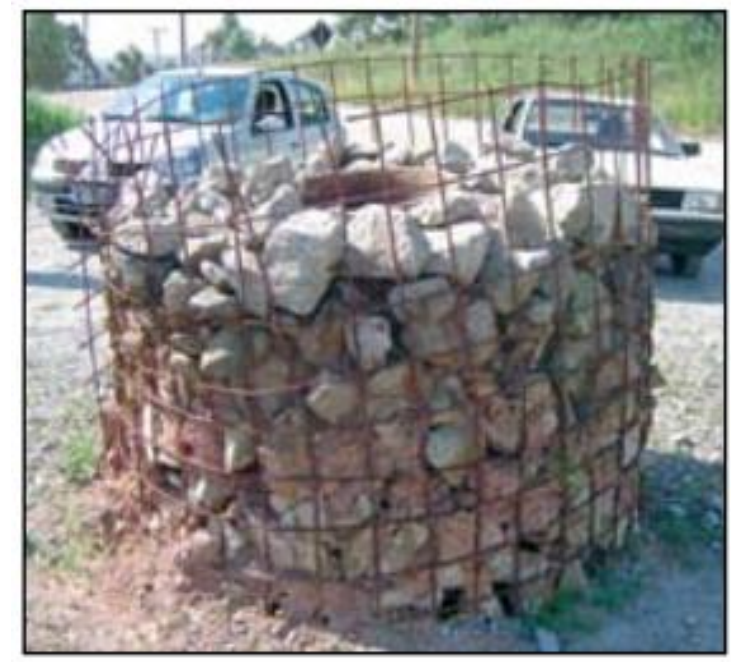

Figura 39 - Dreno típico de aterros, que pode ser adaptado e inserido no sistema de captação de biogás. Fonte: Acervo CENBIO.

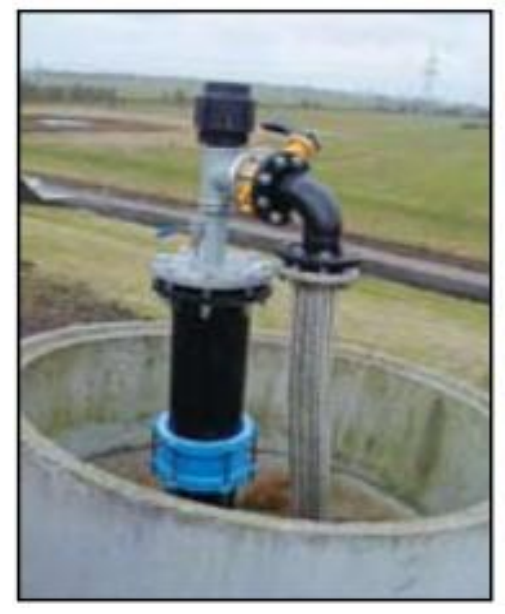

Figura 40 - Cabeçote de adaptação de dreno existente. Modelo utilizado na Europa e EUA. Fonte: Acervo instituto Agir.

As tubulações provenientes dos drenos são interligadas a pontos de regularização de fluxo ou manifolds e estes são interligados a uma linha principal, que conduz o biogás para os sistemas de queima em flare e/ou reaproveitamento energético. A força motriz para a extração do biogás é a pressão negativa gerada por um soprador, ao qual a linha principal está interligada. O biogás, depois de passar pelos filtros, já isento de partículas sólidas e de gotículas líquidas, entra então no soprador e é encaminhado para a queima controlada no flare e/ou para outros sistemas de aproveitamento energético. O soprador tem a finalidade de succionar o biogás do interior do aterro, conforme mostra a figura 41. 


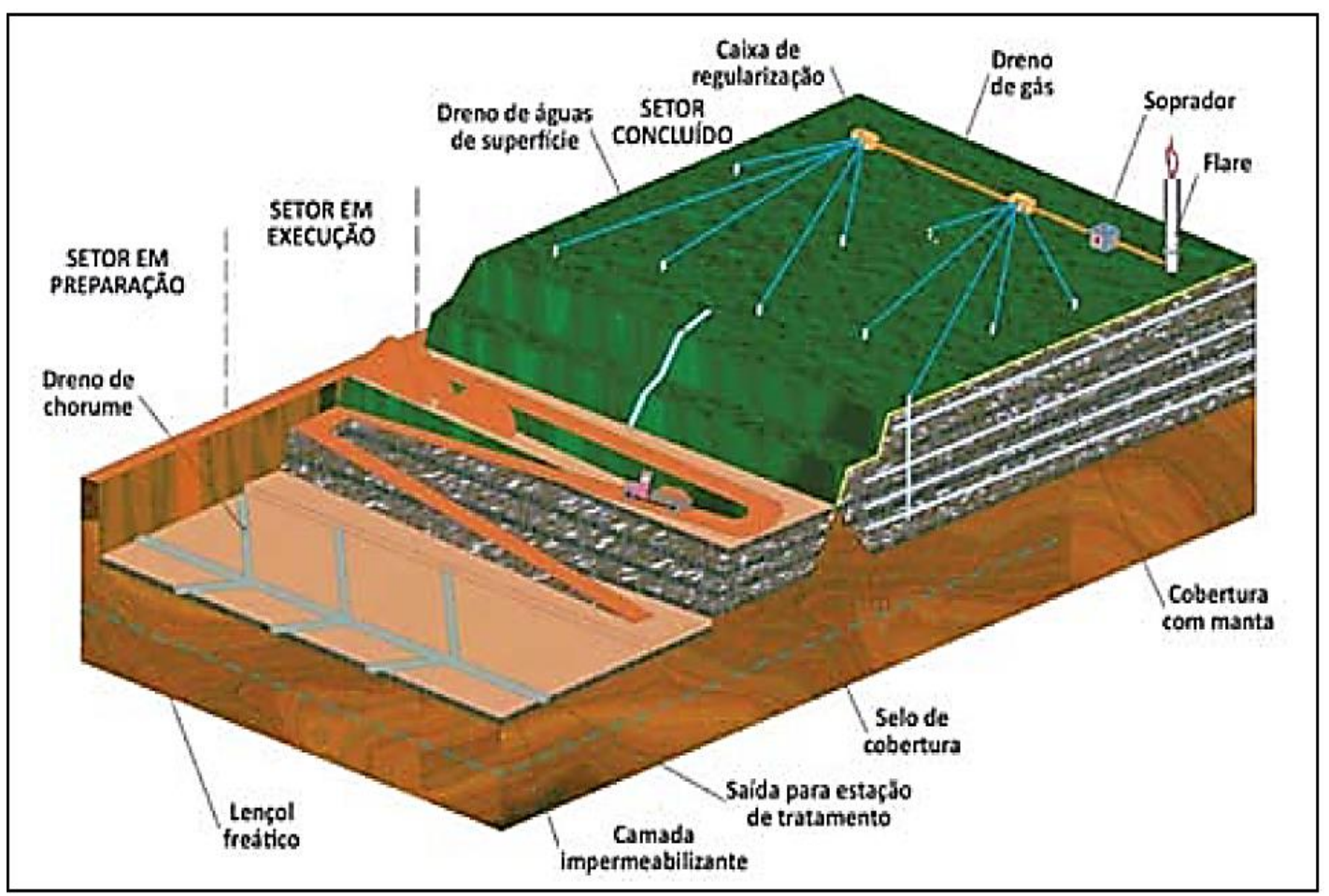

Figura 41 - Desenho esquemático de um sistema de captação de biogás de aterro sanitário. Fonte: Gás de Aterro para Projeto de Energia no Aterro Lara - Mauá - SP.

Documento de Concepção de Projeto - 2004.

O gás extraído do aterro é $100 \%$ saturado, o que resulta no fato de que cada $\mathrm{m}^{3}$ de gás contém aproximadamente 60 a $100 \mathrm{ml}$ de condensado. No ponto de saída dos drenos, a temperatura do gás estará entre $40^{\circ}$ e $50^{\circ} \mathrm{C}$. Pelo resfriamento ao longo da tubulação instalada sobre o aterro, é gerado condensado em grande quantidade (por exemplo, a redução da temperatura de $50^{\circ}$ para $25^{\circ} \mathrm{C}$ gera cerca de $60 \mathrm{~g}$ de condensado por $\mathrm{m}^{3}$ ).

Uma vez que toda a tubulação deverá ser instalada com caimento de no mínimo 3\% e o líquido será direcionado até os pontos mais baixos do sistema. Para evitar o entupimento dos tubos e a perda de vácuo nas linhas, devem ser previstos nestes pontos drenos com sifões, para permitir que o condensado reinfiltre no depósito do lixo. O biogás pode ser recolhido para o aproveitamento energético através da ligação de todos os drenos verticais com um ramal central. A Figura 42 apresenta a esquematização de um sistema de captação do biogás e posterior geração de energia elétrica em um aterro sanitário. 


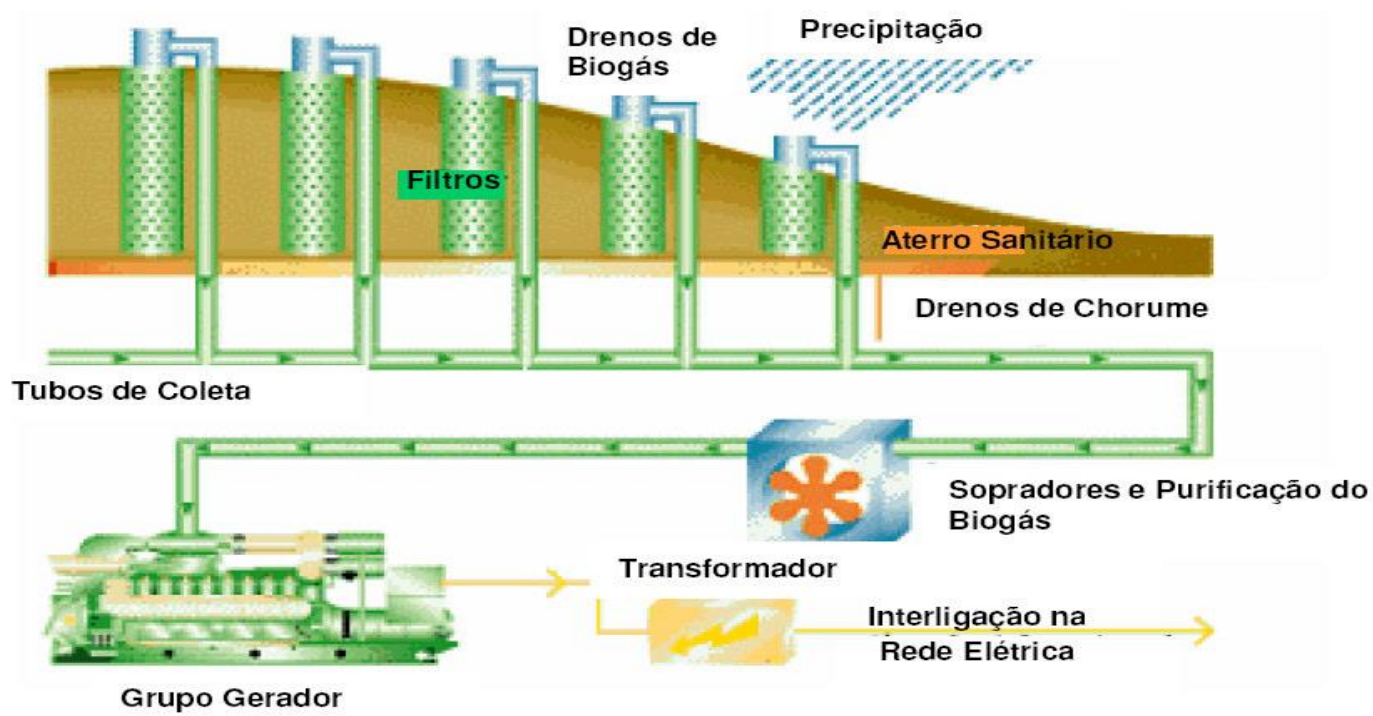

Figura 42 - Sistema de captação do biogás e geração de energia elétrica em aterro sanitário. Fonte: WILLUMSEN, 2001.

Sistema de queima em flares: O biogás captado do aterro pode ser queimado em flare $^{6}$, onde ocorre à transformação de metano em dióxido de carbono, ou então convertido em energia elétrica e/ ou térmica.

Nos flares mostrados na figura 43, o biogás é queimado a altas temperaturas (em torno de $1000^{\circ} \mathrm{C}$ ) para que ocorra a total destruição das moléculas de metano. Independentemente da utilização energética escolhida para o biogás, recomenda-se a instalação de um flare enclausurado, especialmente para projetos destinados à obtenção de créditos de carbono. Isto porque, em caso de falha no sistema de geração de energia ou outro tipo de aproveitamento, evita-se a emissão de metano para a atmosfera e a consequente perda de créditos de carbono.

\footnotetext{
${ }^{6}$ Construídos em aço carbono e isolados internamente com fibra cerâmica, possuem queimadores internos fixados em um coletor inferior, interligados com o duto do biogás. Este duto principal de biogás, por sua vez, apresenta uma bifurcação, destinada ao envio do gás para os sistemas de geração de energia ou outras finalidades de reaproveitamento antes da queima. A ignição e manutenção da chama são feitas através de um queimador piloto, o qual normalmente utiliza GLP (gás liquefeito de petróleo) como combustível inicial.
} 


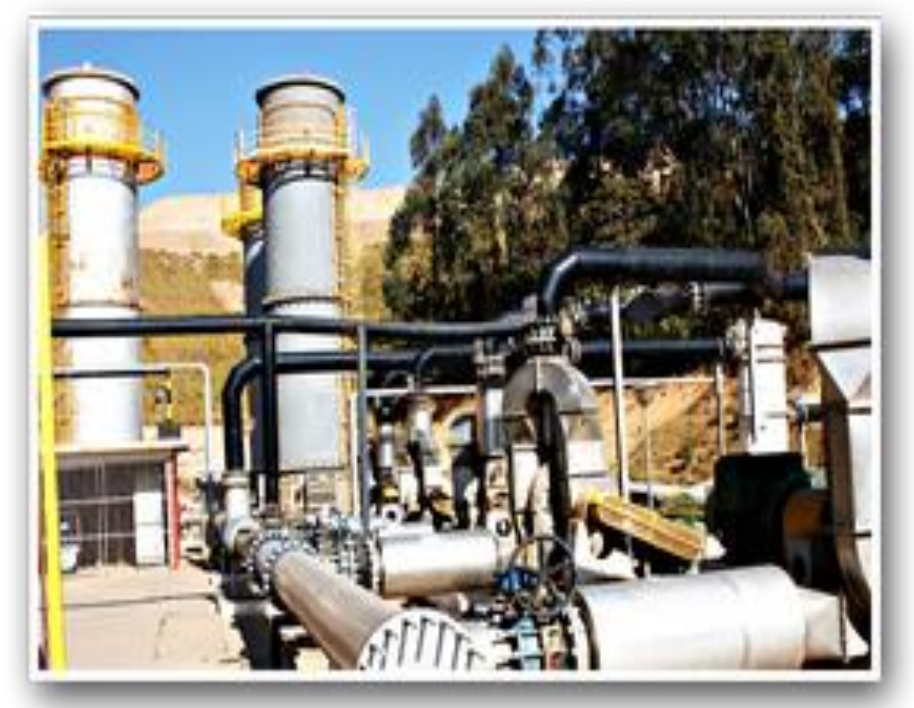

Figura 43 - Flares de aterros sanitários. Fonte: ICLEI (2009).

\section{Controle dos resíduos dispostos no aterro}

Para um efetivo controle da quantidade de resíduos que chega a um aterro, o ideal é que tenha uma balança tipo plataforma para pesagem dos caminhões que os trazem. Com o adequado controle dessas pesagens, pode-se dimensionar a quantidade de resíduos que efetivamente são dispostos no aterro. A partir dos totais anuais, desde o início da operação, calcula-se a taxa de crescimento e estima-se sua capacidade para receber novos resíduos até o encerramento do aterro (ICLEI, 2009).

Quando o aterro não dispõe de balança, a estimativa da quantidade de resíduos se faz com base no número de caminhões de lixo, ou caçambas, multiplicado pelo peso médio de resíduos que transportam. A imprecisão deste método compromete o planejamento da geração e aproveitamento de biogás.

\section{Monitoramento ambiental}

O monitoramento das massas d'água do entorno do aterro deve começar antes do início da operação, com a coleta e análise de amostras dos corpos d'água próximos, inclusive do lençol freático, para avaliar a qualidade atual dos mesmos e poder efetuar comparações futuras.

O segundo instante do monitoramento ambiental se dá a partir do momento em que se inicia a captação do chorume para tratamento. A frequência 
de amostragem, assim como os parâmetros a serem analisados devem ser estabelecidos em comum acordo com o órgão de controle ambiental. (MONTEIRO, 2001).

\section{Monitoramento geotécnico e topográfico}

Todo o trabalho de enchimento das células do aterro deve ser acompanhado topograficamente, até a execução da declividade do platô final acabado, dos drenos secundários e do coletor principal, de modo a assegurar o perfeito escoamento do chorume.

Além desses acompanhamentos executivos, devem ser implantados marcos de concreto nas frentes de trabalho, de sorte a permitir calcular-se o recalque diferencial das camadas aterradas. Esses marcos devem ser lidos mensalmente, ou mais frequentemente no caso de recalques expressivos. A leitura desses marcos também servirá para a verificação da estabilidade geotécnica do aterro, através da medição dos deslocamentos horizontais dos mesmos. (MONTEIRO, 2001).

\subsection{2}

\section{Aterros como biorreatores}

Um aterro de resíduos sólidos pode ser considerado como um grande reator biológico, em vez de funcionar apenas como um local de deposição, onde as principais entradas são os resíduos e a água e as principais saídas são os gases e o chorume (MMA, Ministério do Meio Ambiente, 2012).

Para aumentar a produção de gás, e prolongar a sua vida útil, existem alguns aterros que utilizam a recirculação de chorume.

As operações tradicionais de deposição de resíduos em aterro implicam longos tempos de estabilização e produção de efluentes gasosos e líquidos susceptíveis de causar impactos ambientais negativos que requerem monitorização contínua. (MATOS, 2008).

De acordo com Matos (2008), constatou-se que, com a recirculação de lixiviados, a produção de biogás para aproveitamento energético era cerca de 1,4 a 2 vezes superior. 
Em estudo do Banco Mundial (2004), é fundamental o controle do teor de umidade e de outros fatores que influenciam a população microbiológica que produz o biogás. E pode ter um grande impacto na sua produção.

Esta técnica de recirculação do lixiviados pode produzir grandes taxas iniciais de geração de biogás, que diminuem progressivamente depois de alguns anos. Dependendo da finalidade do uso do biogás, a produção mais prolongada é mais interessante, tendo assim uma vazão menor, mas que assegura o fluxo de metano por mais tempo.

A principal característica do chorume é a variabilidade de sua composição em decorrência do esgotamento progressivo da matéria orgânica biodegradável. Por essa razão, o elevado potencial poluidor do "chorume novo" vai se reduzindo paulatinamente até atingir níveis que dispensam seu tratamento, ao final de 10 anos ("chorume velho").

Também o volume de chorume produzido num aterro varia sazonalmente em função das condições climáticas da região e do sistema de drenagem local, sofrendo a influência da temperatura, do índice de precipitação pluviométrica, da evapotranspiração, da existência de material de cobertura para as células, da permeabilidade do material de cobertura utilizado, da cobertura vegetal da área do aterro e ainda de muitos outros fatores.

Outra forma usual de se tratar o chorume é através de sua recirculação para o interior da massa de lixo com a utilização de aspersores, caminhão-pipa ou de leitos de infiltração. Nesse processo, o chorume vai perdendo sua toxicidade (basicamente carga orgânica), pelo fato de estar sendo aerado e também pela ação biológica dos microorganismos presentes na massa de lixo. Além disso, parte do chorume recirculado sofre evaporação, sendo importante que os bicos dos aspersores sejam regulados.

Visto que a evaporação é um fator importante para a recirculação do chorume, este processo só deve ser adotado em regiões onde o balanço hídrico seja negativo, isto é, em regiões onde a taxa de evaporação é maior do que a precipitação pluviométrica. (MONTEIRO, 2001). 


\section{5 \\ ENERGIA RENOVÁVEL: O BIOGÁS DE ATERROS E SEU APROVEITAMENTO}

\section{1}

\section{Formação do biogás de aterro}

Até ser compactado e coberto, o lixo permanece por certo tempo descoberto no aterro, em contato com o ar atmosférico. Neste período já é verificada a presença do biogás, que continuará sendo emitido após a cobertura e encerramento da célula do aterro.

O biogás originado nos aterros sanitários tem sua composição discriminada na tabela 17 , a seguir:

Tabela 17 - Composição biogás de aterro.

\begin{tabular}{|c|c|}
\hline Composição & Porcentagem (Base seca) \\
\hline Metano & $45-60$ \\
\hline Dióxido de Carbono & $40-60$ \\
\hline Nitrogênio & $2-5$ \\
\hline Oxigênio & $0,1-1,0$ \\
\hline Enxofre, Mercaptanas & $0-1,0$ \\
\hline Amônia & $0,1-1,0$ \\
\hline Hidrogênio & $0-0,2$ \\
\hline Monóxido de Carbono & $0-0,2$ \\
\hline Gases em menor concentração & $0,01-0,6$ \\
\hline
\end{tabular}

Fonte: Tchobanoglous, Theisen\& Vinil (1993).

A porcentagem dos gases constituintes do biogás pode variar dependendo do material utilizado na decomposição. A tabela 18 apresenta alguns componentes dos resíduos e sua velocidade de decomposição. 
Tabela 18 - Tempo de decomposição do lixo.

\begin{tabular}{|c|c|c|}
\hline Componente do lixo orgânico & $\begin{array}{c}\text { Rapidamente } \\
\text { Biodegradável }\end{array}$ & $\begin{array}{c}\text { Lentamente } \\
\text { Biodegradável }\end{array}$ \\
\hline Restos de alimentos & $\checkmark$ & \\
\hline Jornais & $\checkmark$ & \\
\hline Papel de escritório & $\checkmark$ & \\
\hline Papelão & $\checkmark$ & \\
\hline Plásticos* & & \\
\hline Resíduos Têxteis & & $\checkmark$ \\
\hline Borrachas & & $\checkmark$ \\
\hline Couro & & $\checkmark$ \\
\hline Folhas e grama & $\checkmark$ & $\checkmark$ \\
\hline Madeira & & \\
\hline
\end{tabular}

*plásticos são geralmente considerados não-biodegradáveis

Fonte: Adaptado de Tchobanoglous, Theisen \& Vinil, 1993

Na Figura 44, vê-se que a formação e taxa de geração dos principais constituintes do biogás do aterro é variável ao longo do tempo e, em condições normais, a taxa de decomposição atinge um pico entre o primeiro e segundo ano e diminui continuamente por alguns anos. (ENSINAS, 2003). 

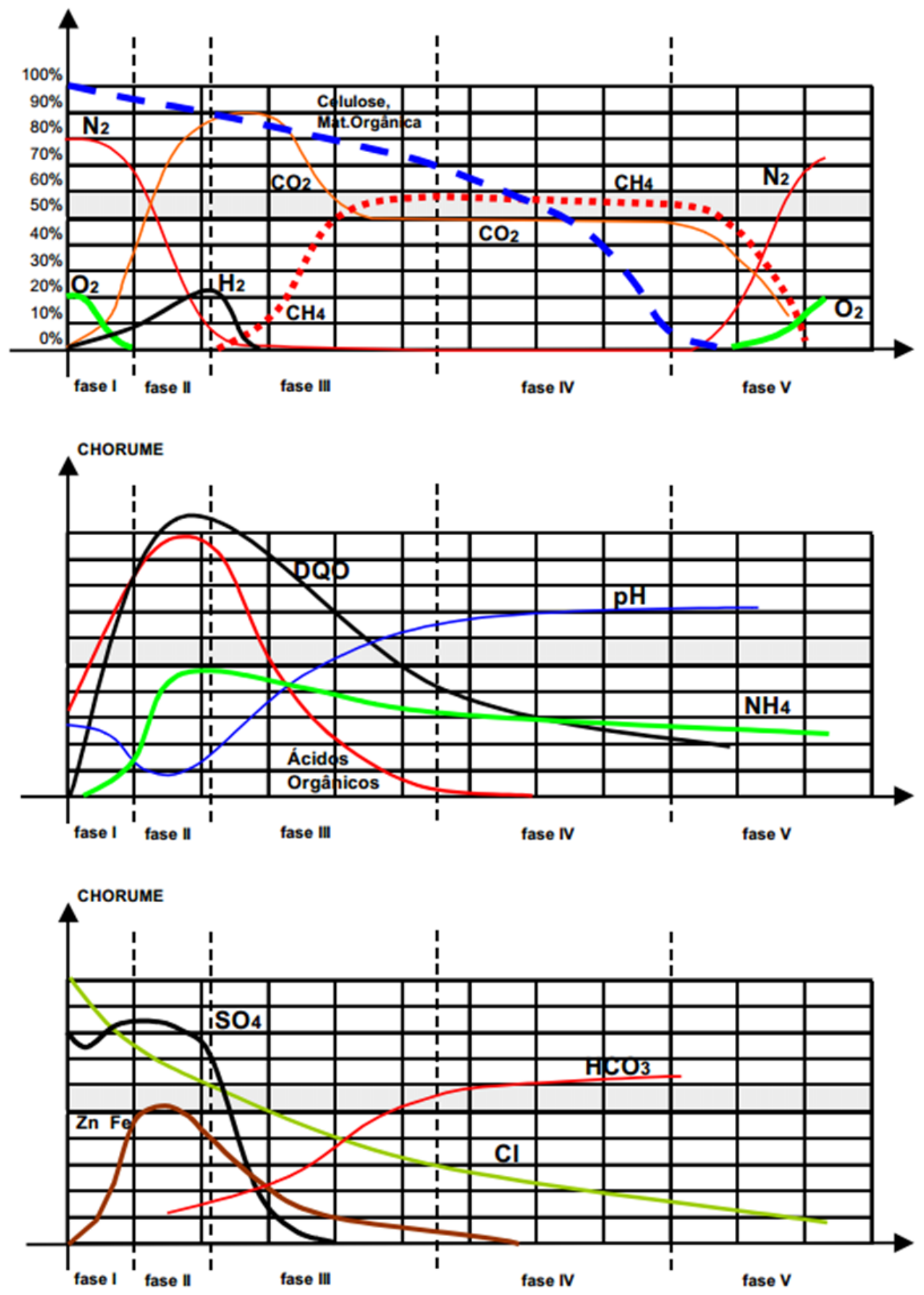

Figura 44 - Fases da geração de biogás e do chorume.

Fonte: Farguhar e Rovers, 1973. Rees, 1980, in: Lima 2002 e Christensen e Kjeldsen,1989, in: Barbosa, 2001).

A tabela 19 a seguir: registra as características das fases da decomposição dos resíduos. 
Tabela 19 - Fases típicas de produção do biogás.

\begin{tabular}{|c|l|l|}
\hline FASES & \multicolumn{1}{|c|}{ CONDIÇÃO } & \multicolumn{1}{|c|}{ DURAÇÂO } \\
\hline I & AERÓBIA & HORAS A 1 SEMANA \\
\hline II & ANÓXICA & 1 A 6 MESES \\
\hline III & $\begin{array}{l}\text { ANAERÓBIA }<\text { METANOGÊNICA } \\
\text { INSTÀVEL }\end{array}$ & 3 MESES A 3 ANOS \\
\hline IV & $\begin{array}{l}\text { ANAERÓBIA }<\text { METANOGÊNICA } \\
\text { ESTÁVEL }\end{array}$ & 8 A 40 +ANOS \\
\hline V & ANAERÓBIA<METANOGÊNICA & 1 A $40+$ ANOS \\
\hline TOTAL & & $\mathbf{1 0 + 8 0 ~ A N O S ~}$ \\
\hline
\end{tabular}

Fonte: Farquhar and Rovers, 1973, Rees, 1980, In Augenstein\& Pacey, 1991 (Banco Mundial, 2004).

A produção de biogás compreende cinco fases distintas:

Fase I (ajuste inicial): A decomposição biológica da matéria orgânica ocorre principalmente em condições aeróbias, devido á presença de certa quantidade de ar no interior do aterro. A principal fonte de micro-organismos para a decomposição aeróbia e anaeróbia nessa fase é a terra que é usada como material de cobertura para divisão das células de aterro e como camada final.

Fase II (transição): Fase em que decrescem os níveis de oxigênio e começa a fase anaeróbia. Enquanto o aterro é convertido em anaeróbio, o nitrato e o sulfato, que podem servir como receptores de elétrons em reações de conversão biológica, frequentemente são reduzidos a gás nitrogênio e sulfuro de hidrogênio. O início das condições anaeróbias pode ser verificado através do potencial de oxidação e redução que possui o resíduo. Com a queda do potencial de óxidoredução os microorganismos responsáveis pela conversão da matéria orgânica em metano e dióxido de carbono iniciam a conversão do material orgânico complexo em ácidos orgânicos e outros produtos intermediários. Nesta fase $\mathrm{o} \mathrm{pH}$ do chorume começa a cair devido à presença de ácidos orgânicos e pelo efeito das elevadas concentrações de $\mathrm{CO}_{2}$ dentro do aterro 
Fase III (ácida): as reações iniciadas na fase de transição são aceleradas com a produção de quantidades significativas de ácidos orgânicos e quantidades menores de gás Hidrogênio. A primeira das três etapas do processo envolve transformação enzimática (hidrólise) dos compostos de maior massa molecular (lipídeos, polissacarídeos, proteínas e ácidos nucléicos) em compostos apropriados para o uso como fonte de energia pelos micro-organismos. A segunda etapa do processo (acidogênesis) envolve conversão microbiológica dos compostos resultantes da primeira etapa em compostos intermediários com massa molecular menor, como ácido acético $\left(\mathrm{CH}_{3} \mathrm{COOH}\right)$ e pequenas concentrações de outros ácidos mais complexos. O dióxido de carbono é o principal gás gerado nesta fase e os micro-organismos envolvidos nesta conversão, descritos como não metanogênicos, são constituídos por bactérias anaeróbias escritas e facultativas. As demandas bioquímica (DBO) e química de oxigênio (DQO) e a condutividade do chorume aumentam significativamente durante esta fase devido à dissolução de ácidos orgânicos no chorume. Também devido ao baixo $\mathrm{pH}$, constituintes inorgânicos como os metais pesados serão solubilizados.

Fase IV (Metanogênica) nesta fase predominam estritamente anaeróbios denominados metanogênicos, que convertem ácido acético e gás Hidrogênio em $\mathrm{CH}_{4}$ e $\mathrm{CO}_{2}$. A formação do metano e dos ácidos prossegue simultaneamente, embora a taxa de formação dos ácidos seja reduzida consideravelmente. $\mathrm{O} \mathrm{pH}$ do chorume nesta fase tende a ser mais básico, na faixa de 6,8 a 8,8.

Fase V (Maturação): Esta fase ocorre após grande quantidade do material orgânico ter sido biodegradado e convertido em $\mathrm{CH}_{4}$ e $\mathrm{CO}_{2}$ durante a fase metanogênica. Como a umidade continua a migrar pela massa de lixo, porções de material biodegradável ainda não convertidos acabam reagindo. A taxa de geração do gás diminui consideravelmente, pois a maioria dos nutrientes disponíveis foi consumida nas fases anteriores e os substratos que restam no aterro são de decomposição mais lenta.

Dependendo das medidas no fechamento do aterro, pequenas quantidades de nitrogênio e oxigênio podem ser encontradas no gás nele produzido. A duração de cada fase de geração de gás variará conforme a distribuição dos componentes 
orgânicos no aterro, a disponibilidade de nutrientes, a umidade dos resíduos, a passagem de umidade pelo aterro e o grau de compactação inicial.

Em condições normais, a velocidade de decomposição, medida através da produção de gás, chega ao máximo nos dois primeiros anos e logo decresce lentamente por 25 anos ou mais. Porém, as fases de um aterro não podem ser claramente definidas, já que novos resíduos são dispostos diariamente. Desta forma, enquanto alguns locais com resíduos novos estão passando pela fase aeróbia, outros locais com resíduos mais antigos estão passando por fases de geração de metano. (BORBA, 2006).

De acordo com USEPA (1991), diversos fatores influenciam a taxa de geração do gás de aterro sanitário:

- Composição dos resíduos: quanto maior for a porcentagem de materiais biodegradáveis, maior a taxa de geração de gases. Os resíduos destinados aos aterros podem ter uma composição variada ao longo do ano, dependendo do clima e dos hábitos de consumo da população.

- Tamanho das partículas: Há uma relação inversamente proporcional entre a superfície exposta dos resíduos e o tamanho dos mesmos, expressa pela superfície específica (área da superfície/volume). Sendo assim, observa-se um aumento da velocidade de degradação quando a massa é composta por resíduos menores, o que tem motivado o uso de trituradores, por exemplo, na compostagem e nos processos mecânico-biológicos. Vale salientar que o tamanho das partículas tem influência na degradação dos resíduos tanto nos processos aeróbios quanto nos anaeróbios.

- Umidade dos resíduos: uma umidade alta (entre 60 a 90\%) pode aumentar a geração do biogás. $\mathrm{O}$ aterro com baixa permeabilidade, para controle da formação dos lixiviados, mantém a umidade dos resíduos baixa e prejudica a formação do biogás. Para muitos aterros, depois da composição, a umidade contida nos resíduos é o fator mais significativo na produção do biogás. (ENSINAS, 2003). 
- Idade dos resíduos e temperatura do aterro: a geração do biogás segue as fases de decomposição dos resíduos descrita anteriormente. A duração de cada fase e o tempo de produção de metano depende das condições de cada temperatura do aterro: a temperatura ideal para a digestão anaeróbia está entre 29 e $38^{\circ} \mathrm{C}$ para as bactérias mesofílicas, e entre 49 e $70^{\circ} \mathrm{C}$ para as termofílicas. Abaixo de $10^{\circ} \mathrm{C}$ tem-se uma queda brusca na geração do metano. Num aterro os resíduos vão sendo depositados ao longo do tempo e os processos de decomposição os afetam de forma diferente, conforme a fase em que se encontram. Resíduos novos possuem maior potencial de geração de metano do que resíduos antigos que, em condições de umidade adequada, já passaram pelos processos de biodegradação.

- pH do aterro: o pH ótimo para a produção de metano está entre 7.0 e 7.2. Inicialmente os aterros apresentam $\mathrm{pH}$ ácido, que tende a aproximar-se da neutralidade a partir da fase metanogênica.

- Forma de construção e operação do aterro: o projeto específico do aterro e a forma de operação influenciam na produção de metano. Aterros com altura elevada e com um sistema eficiente de impermeabilização da camada de cobertura fomentarão o predomínio de atividade anaeróbia, que é a grande responsável pela formação do metano; da mesma forma, a compactação aumenta a densidade da massa de resíduos, o que propicia o encurtamento da fase aeróbia.

\section{2}

\section{Estimativas do potencial de geração de biogás no aterro}

O cálculo de geração de biogás, nos aterros, observa diferentes tecnologias (IPCC, USEPA, Banco Mundial). As tecnologias em causa têm em comum considerar os dados correspondentes à massa de resíduos que o aterro recebe anualmente, o tempo de atividade do aterro (inclusive após seu fechamento), a taxa de geração de biogás e o potencial de sua geração.

De acordo com Borba (2006), a capacidade potencial de geração de metano $\mathrm{L}_{\mathrm{o}}$ depende unicamente do tipo de resíduos e varia entre 5 e $310 \mathrm{~m}^{3} \mathrm{CH}_{4} / \mathrm{t}$ 
resíduo e a taxa de sua geração vai ser diretamente proporcional à velocidade de geração do biogás e de esgotamento do vazadouro, tudo variando em função da umidade, tipo de resíduo, disponibilidade de nutrientes, $\mathrm{pH}$ e temperatura.

As taxas mais rápidas $(\mathrm{k}=0,2$ ou uma meia vida de aproximadamente 3 anos) estão vinculadas a condições de elevada umidade e materiais rapidamente degradáveis, como os restos de alimentos. As taxas de decomposição mais lentas ( $\mathrm{k}=0,03$ ou uma meia vida de aproximadamente 23 anos) se associam a aterros de resíduos secos eresíduos de degradação lenta, como a madeira ou o papel.

\section{Metodologia IPCC}

As diretrizes do IPCC - Painel Intergovernamental de Mudanças Climáticas - (1996), descrevem dois métodos para estimar as emissões de metano procedentes de aterros: o método simplificado, que tem como base a suposição de que o total de metano potencial se libera durante o ano em que se produz a disposição dos resíduos, equação (6), e o método de decomposição de primeira ordem, equações (7) e (8). O método de decomposição de primeira ordem gera um perfil de emissões que depende do tempo transcorrido e que reflete melhor as verdadeiras pautas do processo de degradação ao longo do tempo.

$$
\begin{aligned}
& \mathrm{CH}_{4}(\text { t/ ano })=\left(R S U_{T} * R S U_{F}^{*} L_{0}-R(t)\right) *(1-O X) \\
& \mathrm{CH}_{4} \text { gerado }(\text { t } / \text { ano })=\sum\left\lfloor\left(A^{*} k * R S U_{T}(x) * R S U_{F}(x) * L_{0}(x)\right) * e^{-k(t-x)}\right\rfloor
\end{aligned}
$$

$$
\mathrm{CH}_{4} \text { emitido }(\text { t/ ano })=\left[\mathrm{CH}_{4} \text { gerado }-\mathrm{R}(t)\right] *(1-\mathrm{OX})
$$

Em que:

$\mathrm{t}=$ ano de realização do inventario.

$\mathrm{x}=$ ano de contribuição (desde inicio de atividade até $\mathrm{t}$ ).

$\mathrm{A}=(1-\mathrm{e}-\mathrm{k}) / \mathrm{k}$; fator de normalização para corrigir a soma.

$\mathrm{k}=$ constante de geração, ano-1 
$\operatorname{RSUT}(\mathrm{x})=$ total de RSU gerados no ano $\mathrm{x}$, t/ano.

$\operatorname{RSUF}(\mathrm{x})=$ fração de RSU depositada no aterro no ano $\mathrm{x}$.

$\operatorname{RSUT}(\mathrm{x}) * \operatorname{RSUF}(\mathrm{x})=$ massa de resíduos despejada no ano $\mathrm{x}$, t/ano

$\mathrm{L}_{0}=$ potencial de geração de metano (t CH4/t RSU);

$\mathrm{L}_{0}=\mathrm{FCM}(\mathrm{x}) * \operatorname{COD}(\mathrm{x}) * \mathrm{CODF}^{*} \mathrm{~F}^{*} 16 / 12$.

$\operatorname{FCM}(\mathrm{x})=$ fator de correção do metano no ano $\mathrm{x}$.

$\operatorname{COD}(\mathrm{x})=$ fração de carbono orgânico degradável no ano x (t C/t RSU).

CODF $=$ fração do carbono orgânico degradável assimilado.

$\mathrm{F}=$ fração de metano no gás do aterro, na ausência de dados 0,5 .

$16 / 12$ = conversão de carbono a metano.

$\mathrm{R}(\mathrm{t})=$ quantidade de metano recuperada no ano $\mathrm{t}$.

$\mathrm{OX}$ = fator de oxidação (fração).

A equação (7) não fornece uma representação adequada de aterros de RSU fechados, já que a fração exponencial é sempre crescente, o que gera um aumento constante na geração de biogás. Se por outro lado for considerado o ingresso de resíduos ao aterro como zero, a equação é zerada.

\section{Determinação do fator de correção para o Metano}

O IPCC (1996), no documento guia para a realização de inventários de gases de efeito estufa, propõe valores do FCM em função do tipo de aterro onde se realize a eliminação dos RSU. Classifica os vazadouros em duas categorias, controlados e não controlados, e designa um valor do FCM a cada um deles.

Aos aterros controlados designa um valor do FCM de 1. O IPCC define como aterros controlados aqueles nos quais existe uma deposição controlada dos resíduos, ou seja, áreas específicas para depositar os resíduos e certo grau de controle da coleta do lixo. Ainda, deverá ser utilizado pelo menos um dos seguintes procedimentos: material de cobertura, compactação mecânica ou nivelamento de desperdícios. Para aterros não controlados, denominados vazadouros ou lixões, os valores de FCM que o IPCC recomenda variam com a altura da pilha de disposição, como indicado na Tabela 20. 
Tabela 20 - FCM recomendado pelo IPCC.

\begin{tabular}{ll}
\hline \multicolumn{1}{c}{ LDRS } & FCM \\
\hline Altura maior ou igual a $5 \mathrm{~m}$ & $80 \%$ \\
Altura menor que $5 \mathrm{~m}$ & $40 \%$ \\
Locais sem classificação & $60 \%$ \\
\hline
\end{tabular}

Fonte: CETESB (2002).

\section{Constante de geração}

A constante de geração, $k$, representa a velocidade de degradação da matéria orgânica. Se este parâmetro não estiver caracterizado o IPCC recomenda um valor de 0,05 .

\section{Carbono Orgânico Degradável (COD)}

O carbono orgânico degradável é a fração acessível para a decomposição bioquímica dos resíduos. A Tabela 21 mostra os valores recomendados pelo IPCC para os diferentes resíduos.

Tabela 21 - Valores recomendados para o COD nos principais tipos de resíduos.

\begin{tabular}{cc}
\hline COMPONENTE & PORCENTAGEM DE COD EM MASSA \\
\hline A. PAPEL, PAPELÅO E TECIDOS & 40 \\
B. RESIDUOS DE PARQUES E JARDINS & 17 \\
C. RESTOS DE ALIMENTOS & 15 \\
D. MADEIRA & 30 \\
\hline
\end{tabular}

Fonte: IPCC (1996).

Para o cálculo do COD é necessária a seguinte equação:

COD (fração) $=0,4$ A+0,17 B+0,15 C+0,30 D

Em que: 

A: Fração dos RSU que corresponde ao papel e aos têxteis.
B: Fração dos RSU que corresponde aos resíduos de jardins e parques e outros resíduos orgânicos putrescíveis (excluídos os alimentos);
C: Fração dos resíduos que correspondem a restos de alimentos;
D: Fração dos resíduos que correspondem aos resíduos de madeira e palha.

Caso não sejam conhecidas as frações dos resíduos o IPCC recomenda um valor de $12 \%$ para o COD.

\section{Fração do Carbono Orgânico Degradável Assimilado CODF}

O CODF corresponde à fração do carbono orgânico degradável que realmente se degrada. O carbono orgânico degradável não se decompõe totalmente e parte permanece no aterro inclusive durante longos períodos de tempo. Na ausência de dados o IPCC propõe um valor de 77\% para o CODF.

\section{Fator de Oxidação OX}

O fator de oxidação reflete a quantidade de metano procedente dos aterros que se oxida no solo ou em outros materiais que cobrem os resíduos. Estudos realizados demonstram que os aterros sanitários tendem a expressar resultados de oxidação mais altos que os lixões. Até o presente momento não existem valores aceitos internacionalmente e, na ausência de dados, se assume um valor igual a 0 .

O uso de valores de oxidação diferentes de zero é justificado no caso de aterros sanitários mas, em outros casos, o uso de um valor de oxidação diferente de zero deve estar claramente documentado e respaldado por referências. É importante destacar que qualquer quantidade de metano que se recupere deverá descontar-se do volume gerado antes de aplicar um fator de oxidação.

\section{Incertezas associadas}

$\mathrm{Na}$ Tabela 22, é apresentada a faixa de incerteza associada a cada parâmetro. 
Tabela 22 - Incerteza associada aos parâmetros sugeridos pelo IPCC.

\begin{tabular}{|c|c|}
\hline PARÂMETRO & FAIXA DE INCERTEZA \\
\hline$M S W * M^{*} W_{F}$ & $> \pm 10 \%$ \\
\hline $\mathrm{DOC}=0,21$ & $-50 \%,+20 \%$ \\
\hline $\mathrm{DOC}_{\mathrm{F}}=0,77$ & $-30 \%, 0 \%$ \\
\hline $\mathrm{FCM}=1$ & $-10 \%, 0 \%$ \\
\hline$F=0,5$ & $-0 \%, 20 \%$ \\
\hline RECUPERAÇÃO DE METANO ( R ) & $\begin{array}{c}\text { A faixa de incerteza dependerá da forma em que são } \\
\text { estimadas as quantidades de metano recuperado, mas } \\
\text { é provável que essa incerteza seja relativamente } \\
\text { pequena se comparada com outras quando se aplicam } \\
\text { sistemas de medição. }\end{array}$ \\
\hline ox & $\begin{array}{l}\text { O fator OX deverá ser incluído na análise da incerteza } \\
\text { quando tenha sido indicado um valor diferente de zero }\end{array}$ \\
\hline $\begin{array}{c}\text { TAXA DE GERAÇÃODE METANO k } \\
=0,05\end{array}$ & $-40 \%,+300 \%$ \\
\hline
\end{tabular}

Fonte: IPCC (2006).

\section{Metodologia USEPA}

A USEPA apresenta duas metodologias para calcular os gases emitidos pela degradação de Resíduos Sólidos em aterros: uma destinada a sistemas de disposição sem controle, ou seja, em vazadouros ou lixões e a outra destinada ao cálculo das emissões em sistemas de disposição controlada.

\section{a) Sem sistema de controle}

Para o tipo de disposição sem controle é apresentada a equaçãocinética de primeira ordem (1) com a qual podem ser calculadas as emissões de metano. Esta metodologia foi publicada pela USEPA ("Emission factor documentation for AP42 section 2.4. Municipal Solid Waste Landfills") e tem como base a estimativa direta das emissões de metano a partir de um modelo (Land-Gem: Landfill Gas Emission Model): 


$$
Q_{C H 4}=L_{0} \times R \times\left(e^{-k . c}-e^{-k t}\right)
$$

Em que:

$\mathrm{QCH}_{4}=$ Quantidade de Metano gerado no ano t, (mªno);

$\mathrm{L}_{0}=$ Potencial de geração de metano por tonelada de resíduo depositado, ( $\mathrm{m}^{3} \mathrm{CH}_{4} / \mathrm{t}$ resíduo);

$\mathrm{R}=$ Média anual de entrada de lixo no vazadouro, (t/ano);

$\mathrm{k}=$ taxa de geração de metano, (ano-1);

$\mathrm{c}=$ anos desde $\mathrm{o}$ fechamento, $\mathrm{c}=0$ para os ativos, (ano);

$\mathrm{t}=$ anos desde $\mathrm{o}$ inicio da atividade, (ano).

Na Tabela 23 são apresentados os valores que, na ausência de dados, são

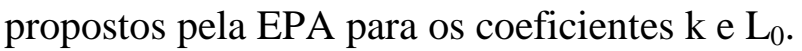

Tabela 23 - Valores de k e L0 propostos pela USEPA.

\begin{tabular}{ccc}
\hline PLUVIOMETRIA ANUAL & $>635 \mathrm{~mm}$ & $<635 \mathrm{~mm}$ \\
\hline$k$ & 0,04 & 0,02 \\
Lo & $100 \mathrm{~m}^{3 / t}$ & $100 \mathrm{~m}^{3 / \mathrm{t}}$ \\
\hline
\end{tabular}

Fonte: USEPA 1998

Se não se conhece R, média anual de entrada de lixo, o mesmo pode ser estimado da seguinte forma:

$\mathrm{R}$ = Capacidade do vazadouro $/ \mathrm{n}^{\mathrm{o}}$. anos em funcionamento;

Capacidade $=$ área do vazadouro $*$ altura da pilha $*$ densidade do lixo;

Se a densidade do resíduo não for conhecida, ela pode ser estimada, utilizando a Tabela 24. 
Tabela 24 - Estimação da densidade do lixo depositado.

\begin{tabular}{cc}
\hline TIPO DE COMPACTAÇÃO & DENSIDADE $\left(\left(\mathrm{kg} / \mathrm{m}^{3}\right)\right.$ \\
\hline LIXO COMPACTADO & $635-831$ (MÉDIA 742) \\
LIXO DEGRADADO COMPACTADO & $1.009-1.127$ (MÉDIA 1.068) \\
SEM DADOS & 688 \\
\hline
\end{tabular}

Fonte: USEPA 1997.

A equação (1) foi concebida inicialmente para estimar a geração de metano e não para estimar emissões, pois parte do metano em sua migração para a atmosfera é captado e degradado nas camadas mais superficiais do terreno. Entretanto, dada a dificuldade em avaliar as emissões, adotando um critério conservador, considera-se que todo o metano gerado é emitido à atmosfera através de fissuras ou vias de evacuação praticadas no terreno.

Conhecendo-se os percentuais em volume de metano e dióxido de carbono, que são os componentes principais do biogás, pode-se estimar o dióxido de carbono emitido à atmosfera.

A emissão de $\mathrm{CO}_{2}$ será calculada pela seguinte equação:

$$
Q_{\mathrm{CO} 2}=Q_{\mathrm{CH}_{4}} *\left(\%(\mathrm{~V}) \mathrm{CO}_{2} / \%(\mathrm{~V}) \mathrm{CH}_{4}\right)
$$

\section{b) Com sistema de controle}

Supondo que exista no aterro um sistema de captação do biogás para sua posterior queima ou aproveitamento para a produção de energia elétrica através de motores de combustão interna ou turbinas, devem ser levados em conta os seguintes aspectos:

- Eficiência do sistema de captação. Os sistemas de captação não são $100 \%$ efetivos, desta forma, parte do biogás gerado é emitido à atmosfera diretamente. Se este dado for desconhecido será utilizado o valor que sugere a USEPA (1998) de 75\% de eficácia de captação.

- Dispositivos de controle. Deve ser levado em conta o dispositivo de controle e/ou aproveitamento do gás do aterro. Na Tabela 25 é apresentada 
a eficiência dos diferentes sistemas de controle em função do dispositivo utilizado.

Tabela 25 - Eficiência do sistema de controle ( $\mathrm{n}$ cont).

\begin{tabular}{cccc}
\hline DISPOSITIVO DE CONTROLE & CONTAMINANTE & $\begin{array}{c}\eta \\
\text { cont(\%) }\end{array}$ & $\begin{array}{c}\text { QUALIDADE DO } \\
\text { FATOR (*) }\end{array}$ \\
\hline QUEIMADOR & VOC & 99,2 & B \\
MOTORES DE COMBUSTÃO & VOC & 97,2 & E \\
INTERNA & VOC & 98,0 & D \\
CALDEIRAS & VOC & 94,4 & E \\
TURBINAS DE GÁS & &
\end{tabular}

Fonte: USEPA 1998

Para estimar as emissões no caso em que existam dispositivos de controle e sempre que não se disponham de dados e/ou medições da própria instalação procede-se da seguinte forma:

\section{- Emissões de $\mathrm{CH}_{4}$ :}

$$
C M_{C H 4}=\left(Q_{C H 4} *\left(1-\eta_{\text {col }} / 100\right)\right)+\left(Q_{C H 4} * \eta_{\text {col }} / 100 *\left(1-\eta_{\text {cont }} / 100\right)\right)
$$

$\mathrm{CMCH}_{4}=$ emissões controladas de metano, (mªno).

$\mathrm{QCH}_{4}=$ emissões não controladas de metano obtidas com a equação (1),(m³/ano).

$\eta$ col = Eficiência do sistema de captação, 75\%, valor sugerido.

$\eta$ cont $=$ Eficiência do dispositivo de controle, ver Tabela 3.3

\section{- Emissões de $\mathrm{CO}_{2}$ :}

$$
C M_{\mathrm{CO}_{2}}=Q_{\mathrm{CO} 2}+\left(Q_{\mathrm{CH} 4} \eta_{\mathrm{col} / 100 * 2,75)}\right.
$$

Em que:

$\mathrm{CMCO}_{2}=$ emissões controladas de $\mathrm{CO}_{2},\left(\mathrm{~m}^{3} / \mathrm{ano}\right)$;

$\mathrm{QCO}_{2}=$ emissões não controladas de $\mathrm{CO}_{2}$ obtidas com a equação (2), ( $\left.\mathrm{m}^{3} / \mathrm{ano}\right)$;

$\eta$ col = Eficiência do sistema de captação, $75 \%$, valor sugerido;

2,75= razão do peso molecular de $\mathrm{CO}_{2}$ e $\mathrm{CH}_{4}$. 
$\mathrm{Na}$ Tabela 26 é apresentada a classificação do tipo de fator e qualidade que ele representa:

Tabela 26 - Códigos de qualidade dos fatores de emissão.

\begin{tabular}{cc}
\hline TIPO DE FATOR & QUALIDADE DO FATOR \\
\hline A & EXCELENTE \\
B & MÉDIO - ALTO \\
C & MÉDIO - ALTO \\
D & MÉDIO - BAIXO \\
E & BAIXO \\
\hline
\end{tabular}

Fonte: Ap-42: seção 11.3, relatório final.

\section{Metodologia Banco Mundial}

O Banco Mundial apresenta no Manual para a Preparação de Gás de Aterro Sanitário para Projetos de Energia na América Latina e Caribe (2003) o Modelo Scholl Canyon que é também um modelo cinético de primeira ordem com base na premissa de que há uma fração constante de material biodegradável no aterro por unidade de tempo. Segundo o Manual citado anteriormente, o modelo foi selecionado por ser o mais comumente empregado e aceito nas Américas do Sul e do Norte e por sua forma simples de compreender e aplicar. O modelo é representado pela equação (5) apresentada abaixo:

$$
Q_{(\mathrm{CH} 4) \mathrm{i}}=k \times L_{0} \times m_{i} \times e^{-k . t}
$$

Em que:

$\mathrm{Q}\left(\mathrm{CH}_{4}\right) \mathrm{i}=$ Metano produzido no ano i a partir da seção i do resíduo, ( $\left.\mathrm{m}^{3} / \mathrm{ano}\right)$;

$\mathrm{k}=$ Taxa da geração de metano, (anos-1);

$\mathrm{L}_{0}=$ Potencial da geração de metano, $\left(\mathrm{m}^{3} \mathrm{CH}_{4} / \mathrm{t}\right.$ resíduo $) ;$

$\mathrm{m}_{\mathrm{i}}=$ Massa de resíduo despejada no ano i, (t/ano);

e = Anos após o fechamento. 
Os valores sugeridos para a constante de geração de metano (k) estão apresentados na Tabela 27.

Tabela 27 - Valores para k propostos em correspondência com a precipitação anual.

\begin{tabular}{cccc}
\hline Precipitação Anual & \multicolumn{3}{c}{ Campo dos Valores $\mathrm{k}$} \\
\cline { 2 - 4 } & $\begin{array}{c}\text { Relativamente } \\
\text { Inerte }\end{array}$ & $\begin{array}{c}\text { Moderadamente } \\
\text { Degradável }\end{array}$ & $\begin{array}{c}\text { Altamente } \\
\text { Degradável }\end{array}$ \\
\hline$<250 \mathrm{~mm}$ & 0,01 & 0,02 & 0,03 \\
$>250 \mathrm{e}<500 \mathrm{~mm}$ & 0,01 & 0,03 & 0,05 \\
$>500 \mathrm{e}<1000 \mathrm{~mm}$ & 0,02 & 0,05 & 0,08 \\
$>1000 \mathrm{~mm}$ & 0,02 & 0,06 & 0,09 \\
\hline
\end{tabular}

Fonte: Banco Mundial, 2003.

O potencial de geração de metano $\left(\mathrm{L}_{0}\right)$ representa sua produção total por tonelada de lixo. Valores típicos para este parâmetro variam de $125 \mathrm{~m}^{3}$ a $300 \mathrm{~m}^{3}$ de metano/tonelada de resíduo.

O Manual do Banco Mundial propõe a utilização de um valor préestabelecido de $\mathrm{L}_{0}$ de $170 \mathrm{~m}^{3}$ de metano/tonelada de resíduos, conforme a Tabela 28.

Tabela 28 - Valores $L_{0}$ em função da degradabilidade do resíduo.

\begin{tabular}{lcc}
\hline Categorização do Lixo & $\begin{array}{c}\text { Valor Mínimo para } \\
\text { Lo }\end{array}$ & $\begin{array}{c}\text { Valor Máximo para } \\
\text { Lo }\end{array}$ \\
\hline $\begin{array}{l}\text { Lixo Relativamente Inerte } \\
\text { Lixo Moderadamente }\end{array}$ & 5 & 25 \\
Degradável & 140 & 200 \\
Lixo Altamente Degradável & 225 & 300 \\
\hline
\end{tabular}

Fonte: Banco Mundial (2003).

A equação (5) não fornece uma representação adequada de aterros de RSU ativos, já que neste caso a exponencial da equação assume o valor um, o que fornece para aterros sem grandes flutuações no ingresso anual de resíduos uma geração constante de metano, independente do tempo de atividade do aterro.

Apesar dos métodos abordados, nenhum deles demonstrou grande acurácia no caso dos aterros brasileiros, em determinar aproximadamente a produção de biogás. 


\section{3}

\section{Gráfico da emissão de metano do aterro}

A metodologia apresentada pelo Banco Mundial sugere uma velocidade de degradação, representada pelo parâmetro k, mais alta e um potencial de geração de metano, $\mathrm{L}_{0}$, superior aos valores que a USEPA propõe. Porém, ao aplicar ambos métodos, a equação sugerida pela USEPA fornece resultados de geração de metano superiores aos encontrados com a metodologia Scholl Canyon sugerida pelo Banco Mundial.

A metodologia apresentada pelo IPCC permite, conhecendo-se as características dos resíduos depositados no aterro, calcular o valor de $\mathrm{L}_{0}$. $\mathrm{O}$ cálculo efetuado com os dados do aterro estudado fornece, neste caso, um valor de $\mathrm{L}_{0}$ inferior aos valores sugeridos pelas metodologias anteriores. Para o valor de $\mathrm{k}$ o IPCC propõe uma faixa de valores, porém sugere para aterros em que não se conheça a velocidade de degradação um valor intermediário aos valores propostos pela USEPA e pelo Banco Mundial.

A aplicação da metodologia apresentada pelo IPCC para um determinado período fornece quantidades de metano inferiores às obtidas aplicando as metodologias da USEPA e do Banco Mundial. Como pode ser visto no gráfico da Figura 45.

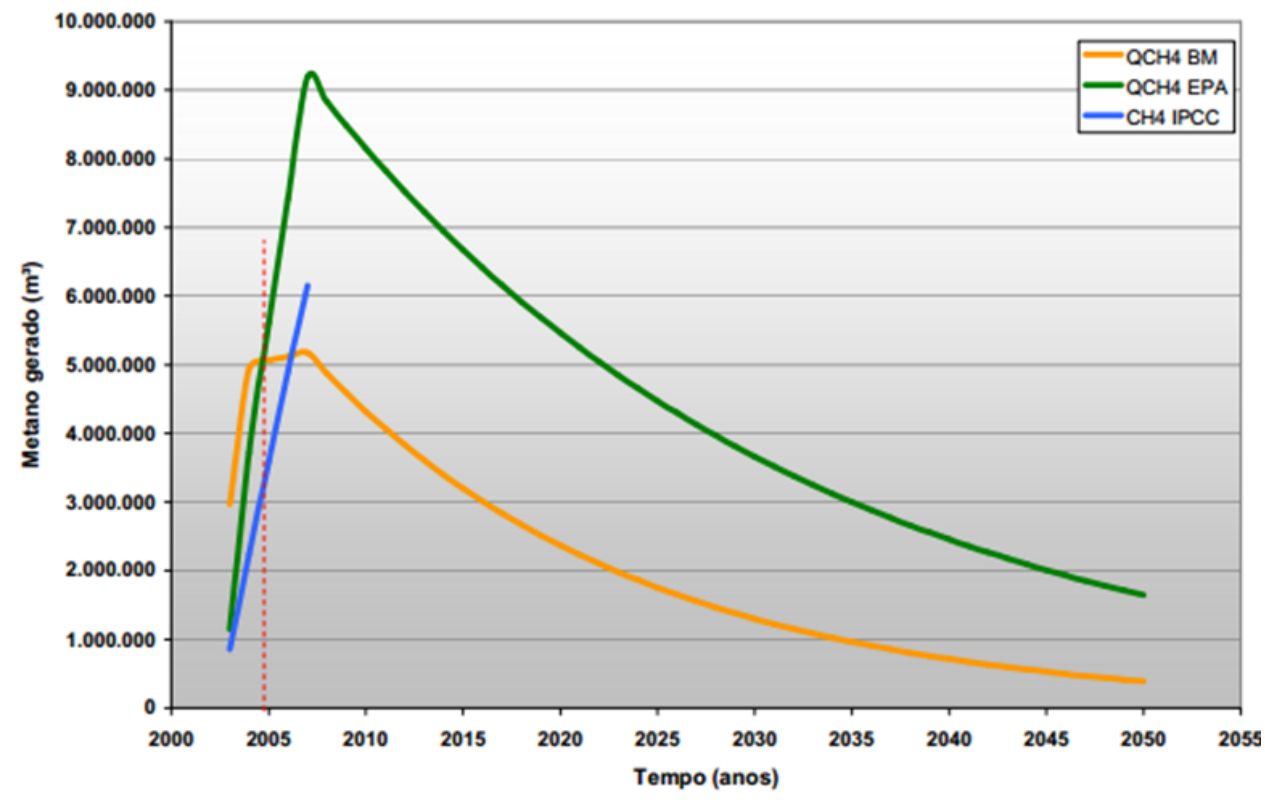

Figura 45 - Curva de geração de metano, em função do tempo do aterro. Interpolação das metodologias da USEPA, B.M., e IPCC. Fonte: (BORBA, 2006). 
Como já foi mencionado anteriormente e pode ser observado na Figura 52 a metodologia do IPCC é adequada para utilização em aterros ativos, enquanto a metodologia do Banco Mundial apresenta uma melhor representação para aterros já encerrados. A metodologia USEPA destaca-se por representar adequadamente a variação de geração de metano tanto para aterros ativos como para aterros já encerrados.

A figura 46 apresenta uma interpolação de resultado na geração de $\mathrm{CH}_{4} \mathrm{em}$ $\mathrm{m}^{3}$, considerando os parâmetros $\mathrm{k}$ e $\mathrm{L}_{0}$ sugeridos por cada modelo, e fixando para as três metodologias os mesmos parâmetros. Para tal são considerados os parâmetros de $\left(\mathrm{k}=0,1\right.$ ano $\left.-1 \mathrm{e} \mathrm{L}_{0}=164 \mathrm{~m}^{3} \mathrm{CH}_{4} / \mathrm{t}\right)$ e uma variação onde se considera $\mathrm{o} \mathrm{L}_{0}$ de projeto e $\mathrm{o} \mathrm{k}=0,05$ ano -1 por ser o valor intermediário das três metodologias propostas. (BORBA, 2006).

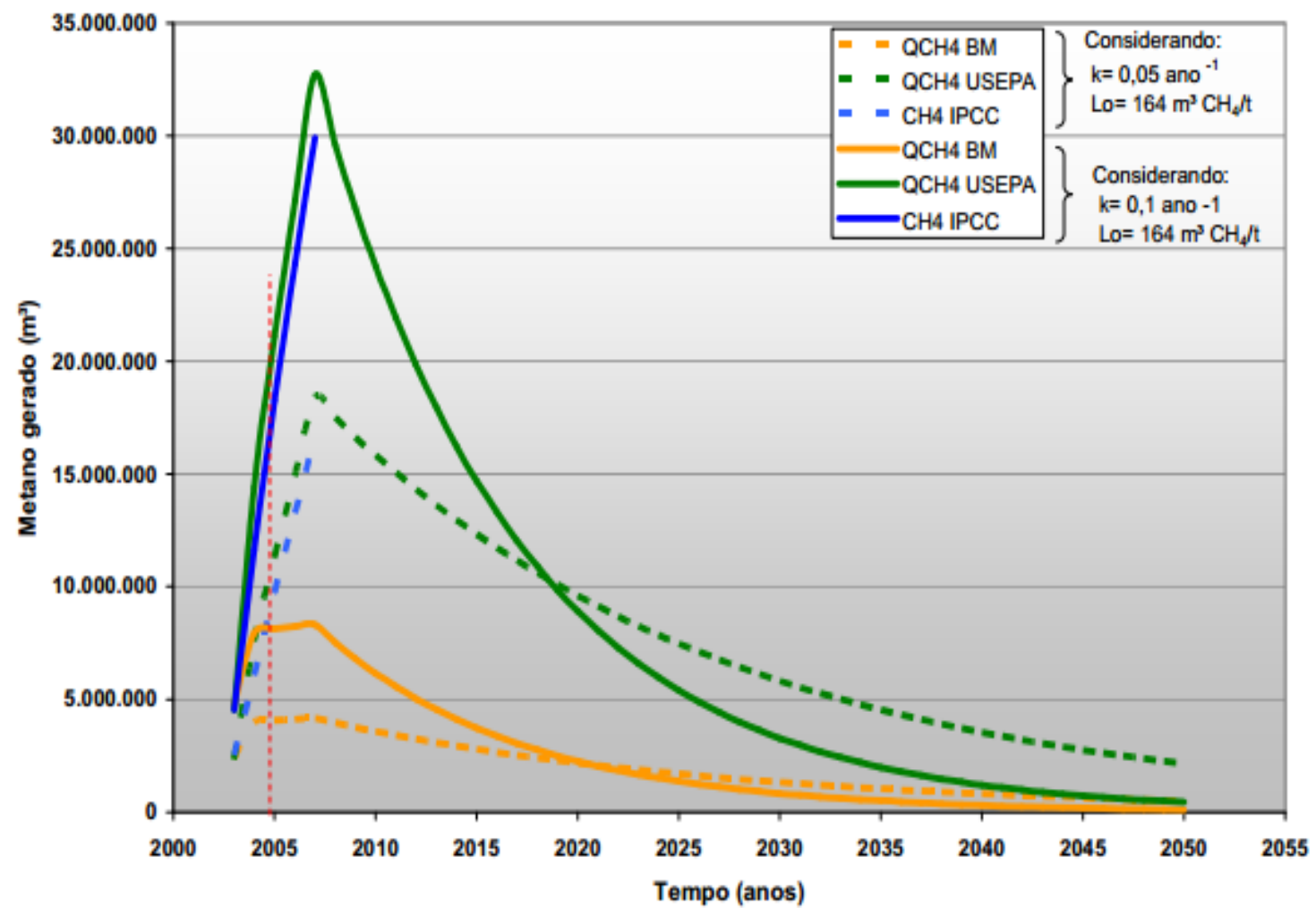

Figura 46 - Curva de geração de metano, em função do tempo do aterro.

Variação das taxas $\mathrm{K}_{0} \mathrm{e} \mathrm{L}_{0}$. Fonte: (BORBA, 2006).

Observa-se que variando a taxa $\mathrm{k}$ de 0,1 para 0,05 os resultados de geração de $\mathrm{CH}_{4}$ são reduzidos praticamente à metade, o que demonstra a importância da sua determinação. 


\section{4}

\section{Determinação do potencial energético do aterro}

Para a determinação da potência e energia utiliza-se as seguintes expressões:

$$
\begin{aligned}
& P=\frac{Q \times \text { PCI } \times \eta}{860.000} \text { Eq. } 4 \\
& E=\text { P } \times \text { Rend } \times \text { Tempo de Operação }
\end{aligned}
$$

Onde:

$\mathbf{P}=$ potência disponível (MW);

$\mathbf{Q}=$ geração de metano no ano $\left(\mathrm{m}^{3} / \mathrm{ano}\right)$;

PCI $=$ Poder Calorífico Inferior do metano. Caso o aterro não possua o valor real do PCI do metano, pode-se adotar $5.500 \mathrm{kcal} / \mathrm{m}^{3} \mathrm{CH}_{4}$ (valor adotado para $50 \%$ de metano presente no biogás de aterro);

$\boldsymbol{\eta}=$ eficiência de motores (geralmente $28 \%=0,28$ );

860.000 = conversão de kcal para MW;

$\mathbf{E}=$ energia disponível (MW h/dia)

Rend $=$ rendimento de motores operando a plena carga $($ estimado em $87 \%=0,87)$

Tempo de operação do motor $=24$ horas $/$ dia

Portanto, em função da vazão de metano, pode-se realizar os cálculos da potência (MW) e da energia (MW h /dia) disponíveis no aterro ano a ano.

\section{Potência comparada do biogás}

O biogás tem seu poder calorífico diretamente relacionado com a quantidade de metano existente na mistura, que pode variar de 5.000 a 7.000 $\mathrm{kcal} / \mathrm{m}^{3}$. Esse poder calorífico pode chegar a $12.000 \mathrm{kcal} / \mathrm{m}^{3}$ uma vez eliminado todo o gás carbônico da mistura. 
Estudo de Deganutti, (2002), estabelece uma relação comparativa de equivalência de $1 \mathrm{~m}^{3}$ de biogás com os combustíveis usuais: - $1 \mathrm{~m}^{3}$ de biogás corresponde a:

- 0,61 litros de gasolina

- $\quad 0,55$ litros de óleo diesel

- $0,45 \mathrm{~kg}$ de gás liquefeito

- 0,79 litros de álcool combustível

- $1,428 \mathrm{kWh}$ de energia elétrica

\section{5}

\section{Meios de aproveitamento energético do biogás}

Diversas técnicas podem ser empregadas para efetuar a conversão energética do biogás dos aterros sanitários e biodigestores, como ilustra a figura 47. Em termos de custos de exploração, quanto mais se purificar o gás, provavelmente mais oneroso vai ficar o processo, tanto pelo valor dos equipamentos (que são bastante variáveis) quanto pelas despesas com a manutenção dos equipamentos e tubulações.

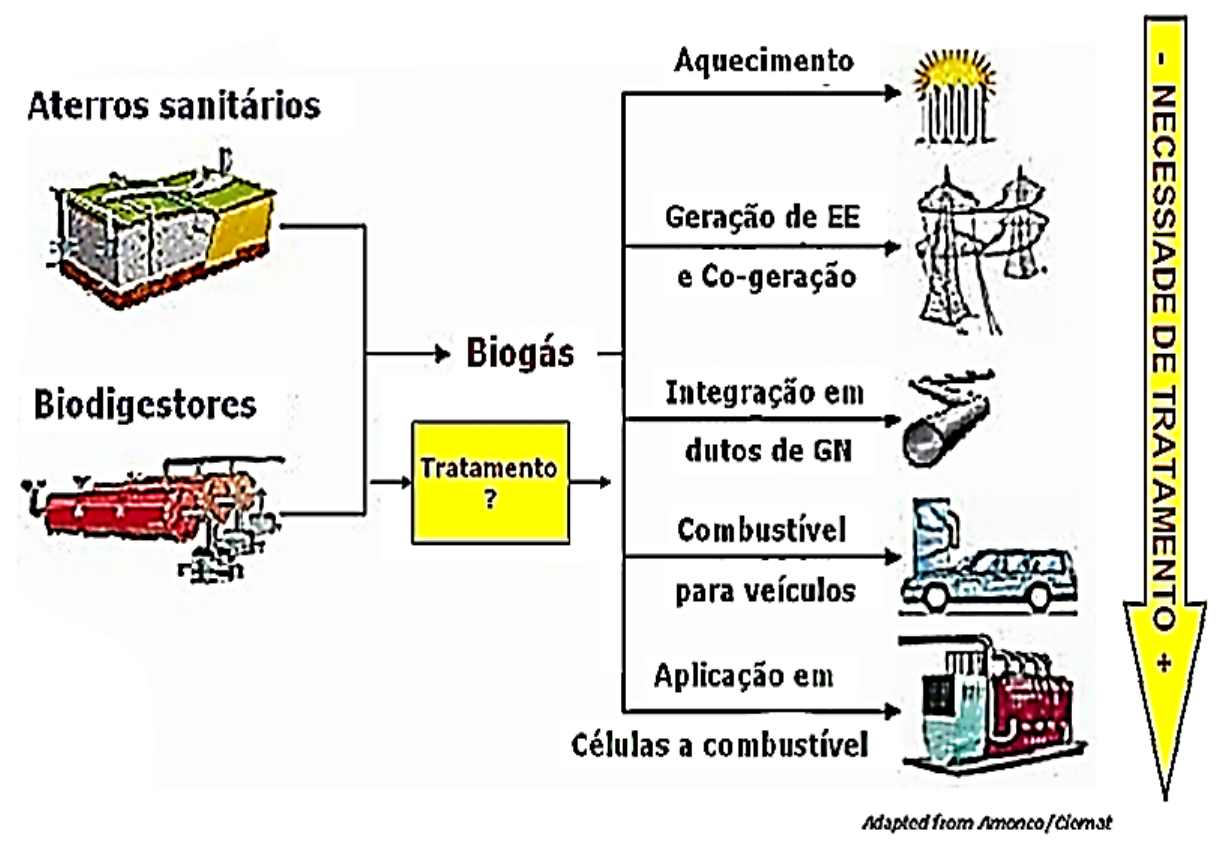

Figura 47 - Esquema de aproveitamento energético do biogás.

Fonte: EBAH (2012). 


\section{5 .1}

\section{Produção do combustível para veículos}

O biogás pode ser utilizado como o é o gás natural, mas, para uso como combustível veicular, há necessidade de remoção de alguns de seus componentes, tais como gás sulfídrico $\left(\mathrm{H}_{2} \mathrm{~S}\right)$, dióxido de carbono $\left(\mathrm{CO}_{2}\right)$ e partículas (Adnett, 2000), além da umidade.

Ao lado da geração de energia, o uso do biogás como combustível de veículos é dos mais interessantes aproveitamentos, quando grande sua produção.

Dos gases que compõem o biogás, o gás carbônico e o gás sulfídrico devem receber atenção especial. São considerados o principal problema no seu armazenamento e na produção de energia. Interferem principalmente na qualidade do biogás; acarretam problemas de corrosão no sistema de sua condução até a transformação como fonte de energia elétrica ou térmica, e necessitam de processos de tratamento. (MAGALHÃES, 1986).

O gás sulfídrico aparece em uma concentração aproximada de $10 \mathrm{~g} / \mathrm{m}^{3}$. Requer um filtro purificador para evitar o mau cheiro gerado e principalmente para retirar seu efeito corrosivo e para chegar a uma concentração abaixo de 1,5g/m³. (OLIVEIRA, 2009).

No processo de purificação do biogás é fundamental retirar o $\mathrm{CO}_{2}$ até que a porcentagem de metano fique próxima à do gás natural, para que possa ser utilizado como combustível veicular. Outros usos do biogás dependem da quantidade de BTUs (British Termal Units) nele contida e da atividade econômica em que será aplicado. O biogás pode ser classificado com base no nível de prétratamento/processamento:

- Combustível com BTU médio. O biogás bruto, ou com pouco tratamento, tem uso comercial e industrial para o abastecimento de aquecedores de água, fornos, secadores de agregados e geradores convencionais de eletricidade. Esse biogás contém tipicamente $50 \%$ de metano. E é passível de ser usado na evaporação do chorume, reduzindo os custos do tratamento deste efluente. As maiores vantagens deste tipo de biogás são: 
- É utilizado por um usuário fora do aterro sanitário;

- O comprimento do gasoduto varia de 0,6 a $15 \mathrm{Km}$. Os menores de 5 $\mathrm{Km}$ tem maior viabilidade financeira;

- Excelente possibilidade de retorno financeiro, se um usuário final se encontra nas proximidades;

- Pode ser utilizado em estufas, que utilizam tanto a energia elétrica quanto o calor. O dióxido de carbono melhora o crescimento das plantas.

- Combustível com BTU alto. O biogás é purificado a níveis de 90 a $99 \%$ do metano, através da remoção do dióxido de carbono, e isto produz o aumento do seu poder calorifico (maior densidade nos tanques de armazenamento). Seu uso ocorre como gás natural ou gás natural comprimido. As maiores vantagens deste biogás são

- Injeção do produto tratado em gasoduto;

- O Metano pode ser usado como matéria- prima. (ex: metanol);

- Redução do consumo de combustíveis fósseis (em especial do diesel), por ele substituídos, inclusive no abastecimento dos caminhões de coleta de lixo, com sensível redução das emissões de particulados, $\mathrm{NO}_{\mathrm{x}}, \mathrm{CO}$, entre outros gases.

Segundo a ANP (Agencia Nacional de Petróleo), na Portaria 128, de 28 de agosto de 2001, a porcentagem mínima de metano no gás natural para uso veicular deve ser de $86 \%$ e máxima de $\mathrm{CO}_{2}$ de $5 \%$. (GODLOVE, 2010).

Recentemente, no Brasil foram descobertas novas reservas abundantes de gás nas bacias terrestres. Ao longo das últimas décadas, o gás natural vem ganhando importância, tanto no cenário mundial, quanto internamente. No entanto, o aumento da participação deste combustível em nossa matriz energética, que é baixa, tem encontrado barreiras ao seu desenvolvimento, dentre elas a pequena malha dutoviária.

O transporte do gás natural é responsável por cerca de $2 / 3$ do seu custo e, portanto, o desenvolvimento da IGN (Indústria do Gás Natural) depende de 
grandes investimentos na infraestrutura de transporte e distribuição, mas mesmo assim, o Brasil possui uma das maiores frota de automóveis movidos a GNV (Gás Natural Veicular) do mundo, segundo o IBP (Instituto Brasileiro de Petróleo, Gás e Biocombustíveis).

Os demais derivados do petróleo (diesel, gasolina, óleo combustível, dentre outros) seguem uma tendência de equilíbrio entre a oferta e a demanda mundial. O gás natural, por ter uma pequena parcela de seus custos incorporados à variação do preço internacional de sua commodity, acompanha apenas em parte a evolução do preço nos mercados externos. (GODLOVE, 2010).

\section{Vantagens da utilização do GNV}

- A média mundial indica que o consumo de GNV é $66 \%$ mais barato do que a gasolina e $33 \%$ mais econômico do que o diesel.

- Motores movidos por GNV/GNC produzem menos $25 \%$ de dióxido de carbono dos que os que são alimentados por gasolina e $35 \%$ menos do que os que usam diesel.

- Reduz as emissões de monóxido de carbono em 95\% em relação à gasolina, as emissões de hidrocarbonetos em $80 \%$ e óxidos de nitrogênio em $30 \%$.

- GNV/GNC não contém enxofre (há motores a diesel em que ocorre a liberação de 18,4g / partículas, chumbo ou traços de metais pesados).

- Ao contrário de gasolina, gás natural para veículos não contêm aditivos tóxicos de chumbo orgânico ou benzeno, sendo este último altamente cancerígeno.

- O gás natural não é tóxico ou corrosivo e não contamina as águas subterrâneas.

- Os motores a GNV/GNC possuem capacidade de diminuir a poluição sonora por ter um desempenho mais suave e mais silencioso que os motores a gasolina e especialmente os a diesel. Restringe significativamente as vibrações, reduzindo assim o ruído do motor.

- O gás natural está em conformidade com os mais rigorosos padrões ambientais exigidos pelos governos e agências reguladoras. É o 
combustível com utilização em larga escala e com os níveis mais baixos de contaminação.

- O circuito de combustível para o gás natural é hermético e não tem ar dentro. Portanto, não há ignição espontânea. Pelo contrário, em reservatórios de líquidos combustíveis, há sempre mistura inflamável, uma vez que são abertos para a atmosfera.

- O gás natural para veículos tem maior octanagem que a gasolina (125 vs 90), o que proporciona combustão sem autoignição, mesmo em motores de maior compressão e eficiência.

- Além disso, a combustão é total, porque a mistura entre GNC/ GNV e ar é perfeita a qualquer temperatura ambiente.

- O óleo que lubrifica o motor é menos contaminado se o gás natural é empregado, e intervalos entre as trocas de óleo são duas vezes mais longos.

- Não há sedimentos e as velas são mantidas limpas. As paredes dos cilindros do motor não são lavadas, o que resulta em lubrificação melhor e mais eficaz.

- Os gases de combustão não são corrosivos. Por não conter metais prejudiciais, a vida útil do tubo de escape e silenciadores é mais longa.

- O motor apresenta flexibilidade e excelente desempenho durante as acelerações, sem irregularidades, mesmo em velocidade baixa.

- Veículos convertidos podem mudar o uso de GNC/ GNV para a gasolina, basta apertar um botão ou girar um botão durante a condução.

- Veículos a gás natural operam em todos os terrenos, mesmo nos mais acidentados. O GNV/GNC funciona bem em qualquer condição climática, uma vez que o combustível não congela nem mesmo a baixas temperaturas. Componentes GNV/GNC são testados a $-40^{\circ}$ C. O gás natural só se liquefaz a $165^{\circ} \mathrm{C}$.

- O veículo pode tornar-se bicombustível. A conversão para o GNV não elimina a possibilidade de utilizar o combustível original.

Fonte: NGV Journal (2012) 


\section{Conversão de veículos pesados movidos a diesel para GNV}

O quilômetro rodado do veículo movido a gás é mais caro, já que existe uma relação de eficiência energética entre o GNV e o diesel da ordem de mais ou menos 23\%, segundo dados do Cenpes /Petrobrás.

No entanto, uma das melhores possibilidades de aproveitamento do biogás é com a conversão de caminhões de coleta mais antigos para transitarem com o GNV. Conforme estudo de Machado et al. (2007), existem 2 alternativas possíveis:

- Diesel- Motor Otto a GNV original

- "Ottolização"

As figuras 48,49 e 50 abrangem a esquematização da conversão de motores, com a enumeração das vantagens e desvantagens de cada técnica.

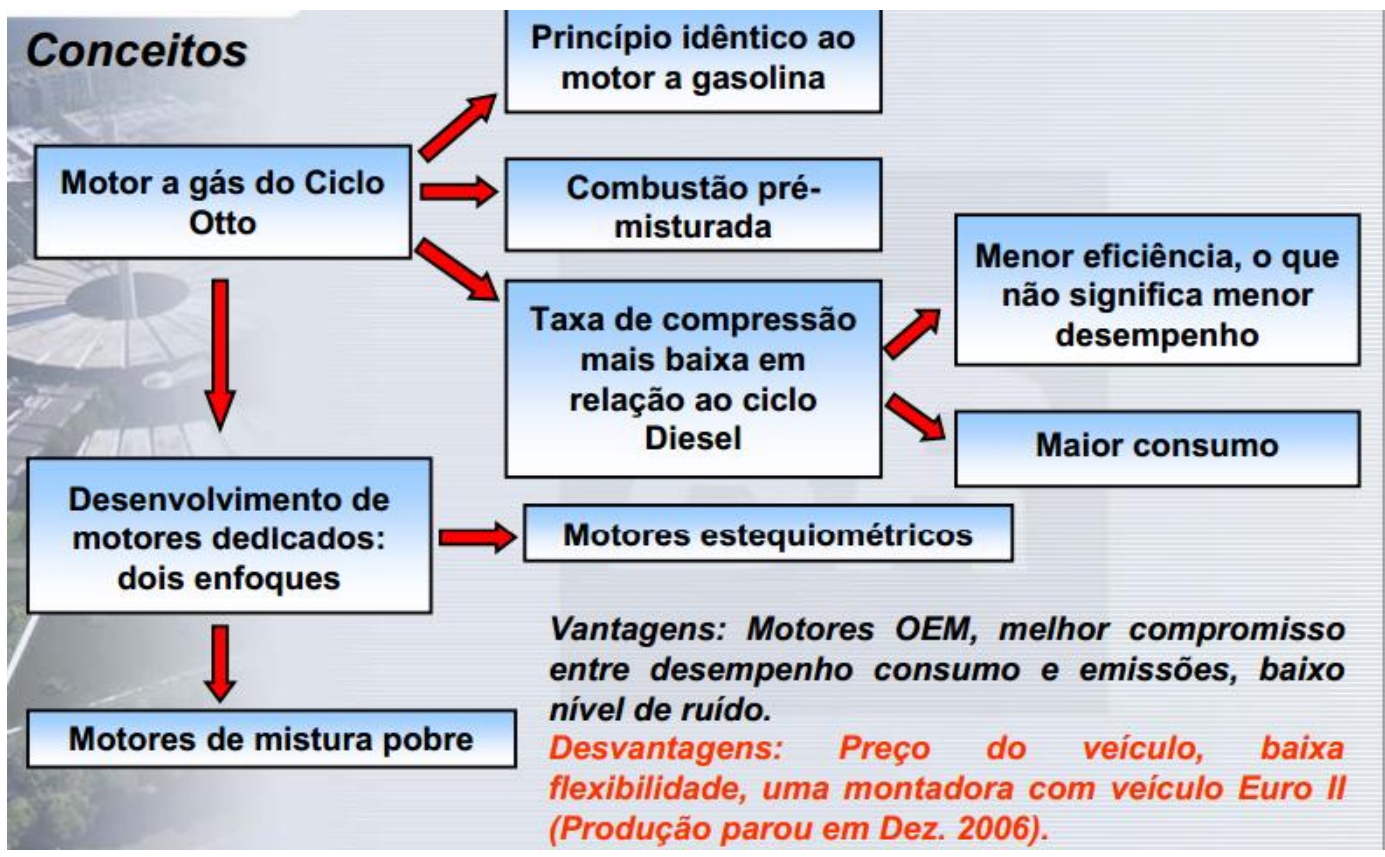

Figura 48 - Conceito de conversão de veículos pesados diesel/GNV.

Fonte: Machado (2007). 


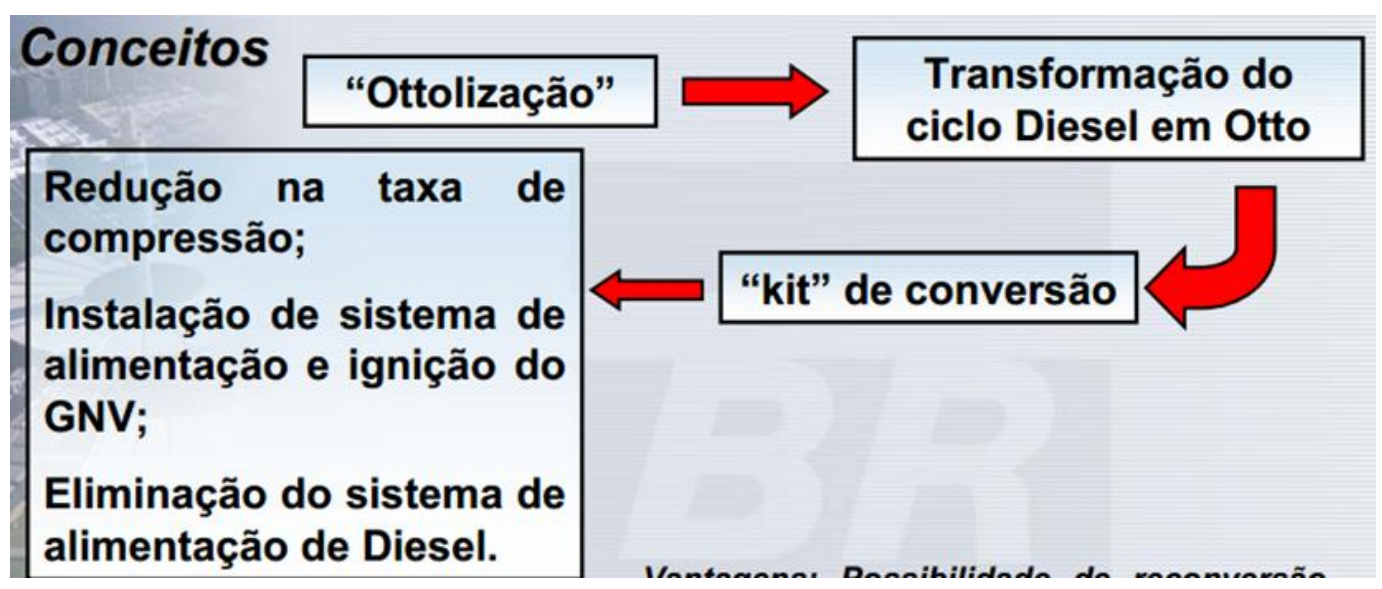

Figura 49 - Conceito esquemático transformação do motor diesel para GNV.

Fonte: Machado (2007).

Vantagens: Possibilidade de reconversão, baixo nível de ruído, mercado de veículos usados.

Desvantagens: Custo de conversão, baixa flexibilidade, disponibilidade de

"kits" para a conversão, enquadramento de emissões.

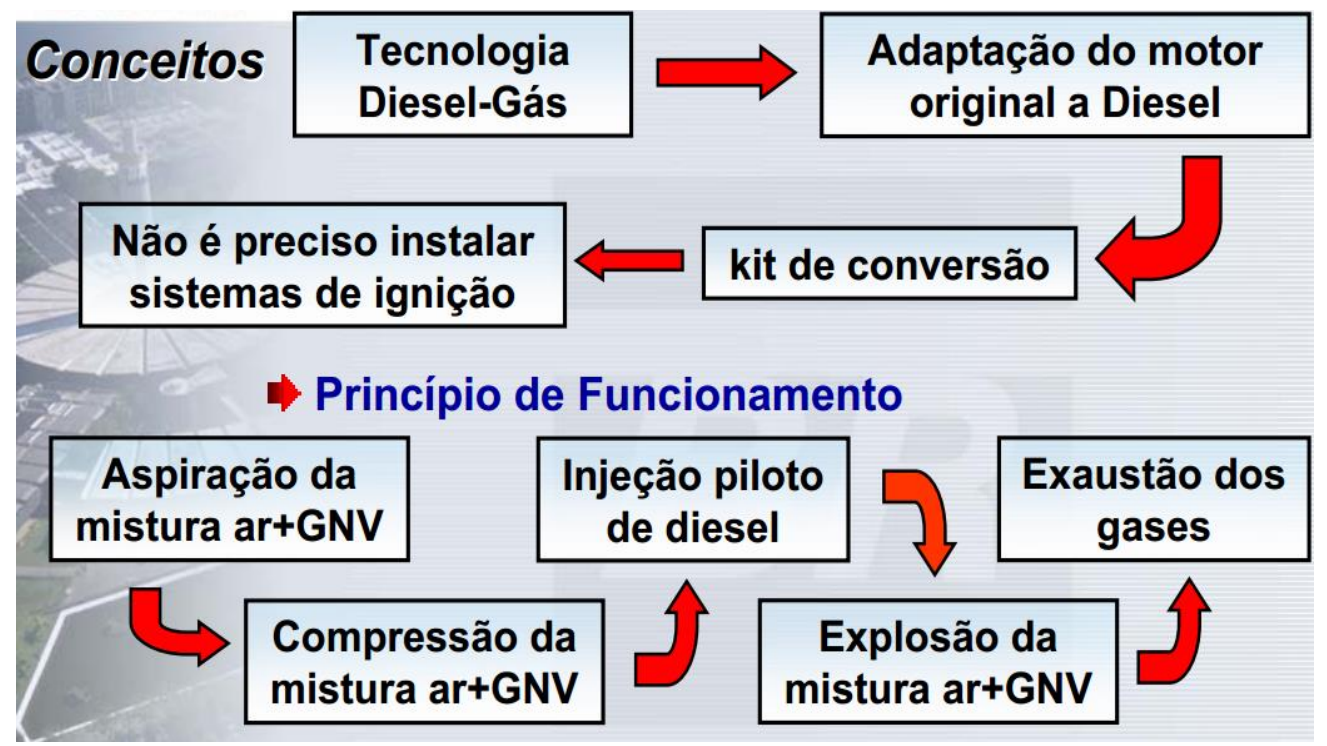

Figura 50 - Conversão por adaptação motor original a diesel.

Fonte: Machado (2007).

Vantagens: Flexibilidade, eficiência do ciclo diesel, baixo nível de ruído.

Desvantagens: custo de conversão, disponibilidade de kits, enquadramento de emissões. 


\section{Características do sistema "dual fuel”( híbrido).}

\section{a) Projeto do Motor - Não sofre alterações}

- Possibilidade da utilização de ambos os sistemas de alimentação através de uma chave comutadora;

- Aumento da autonomia;

- Utilização em regiões onde não exista rede de distribuição de gás.

b) Mistura ar + gás

- Mistura homogênea e bem distribuída;

- Pico e taxa de elevação de pressão reduzida;

- Funcionamento mais silencioso;

- Geralmente utilizam-se misturas mais próximas da estequiométrica.

\section{c) Injeção Piloto}

- Cada gotícula de óleo Diesel funciona como uma frente de chama Motor OTTO com várias centelhas;

- Maior eficiência de queima;

- Utilização de misturas pobres.

Desejável:

- Quantidade mínima de injeção piloto

- Elevados níveis de substituição

Necessário:

- Bomba injetora em boas condições de uso para propiciar uma distribuição homogênea para os cilindros;

- O óleo diesel funciona como refrigerante do bico injetor e deve ser observada a temperatura máxima especificada pelo fabricante;

- Injeção Piloto - no mínimo 5\% do Débito em Potência Nominal. 
d) Variação de carga:

- Especialmente em motores com controle primário da mistura ar + gás;

- Cargas Elevadas: Aumento do Rendimento em até 15\%;

- .Excesso de ar e facilidade de mistura;

- Aproveitamento da elevada taxa de compressão;

- Cargas Baixas: Diminuição do Rendimento;

- Menor velocidade e/ou descontinuidade da frente de chama;

- Queima incompleta ou atrasada;

- Elevação dos teores de HC e CO.

Utilização de componentes que limitam a entrada de gás para cargas superiores a $30 \%$.

e) Fatores que influenciam a detonação:

- Número de Metano;

- Temperatura e pressão da mistura admitida;

- Taxa de compressão;

- Temperaturas e pressões altas ao final da compressão + propagação da frente de chama;

- Detonação da mistura ar + gás não queimada;

- Velocidade baixa maior tendência à detonação devido a tempo maior de pré-reação.

\section{f) Técnicas de Admissão de Gás:}

- Carburação - Bastante simples e geralmente empregada em motores com pequeno cruzamento de válvulas;

- Motores 4 tempos de aspiração natural;

- Injeção Sincronizada - Injeção de gás em quantidades e períodos préestabelecidos e em sincronismo com o funcionamento das válvulas com benefícios para emissões e rendimentos; 
- Motores 2 tempos, eletrônicos e superalimentados.

g) Desgaste do Motor e Estado do Óleo Lubrificante (CENPES-1991):

- Menor formação de depósitos;

- Menores taxas de desgaste;

- Maior durabilidade dos lubrificantes;

- Maior vida útil do motor.

h) Emissões (CENPES-1991):

- Isento de Enxofre;

- Redução drástica da fuligem;

- Redução significativa de material particulado. Atualmente são mais severos limites de emissões, incluindo novos poluentes.

\section{Comparação de emissões entre veículos pesados movidos com diesel, diesel-gás e GNV}

Segundo estudo de Ricardo, 2007, a avaliação dos níveis de emissão de poluentes dos motores a diesel, gás natural comprimido (GNC) e GNC-diesel apurou diferença expressiva nas quantidades emitidas. A tabela 29 e a figura 51 mostram que o diesel apresentou os maiores níveis de emissões gerais na comparação entre os três tipos de motores testados.

Tabela 29 - Emissões de gases por veículos pesados.

\begin{tabular}{lllll}
\hline & MP & NOx & HC & CO \\
& $\mathbf{g} / \mathbf{k m}$ & $\mathbf{g} / \mathbf{k m}$ & $\mathbf{g} / \mathbf{k m}$ & $\mathbf{g} / \mathbf{k m}$ \\
\hline Diesel & 1,15 & 14,60 & 1,35 & 10,35 \\
GNC & 0,01 & 10,13 & 8,35 & 1,55 \\
GNC-Diesel & 0,19 & 9,47 & 6,10 & 2,65 \\
\hline
\end{tabular}

Fonte:André Ricardo, 2007. 


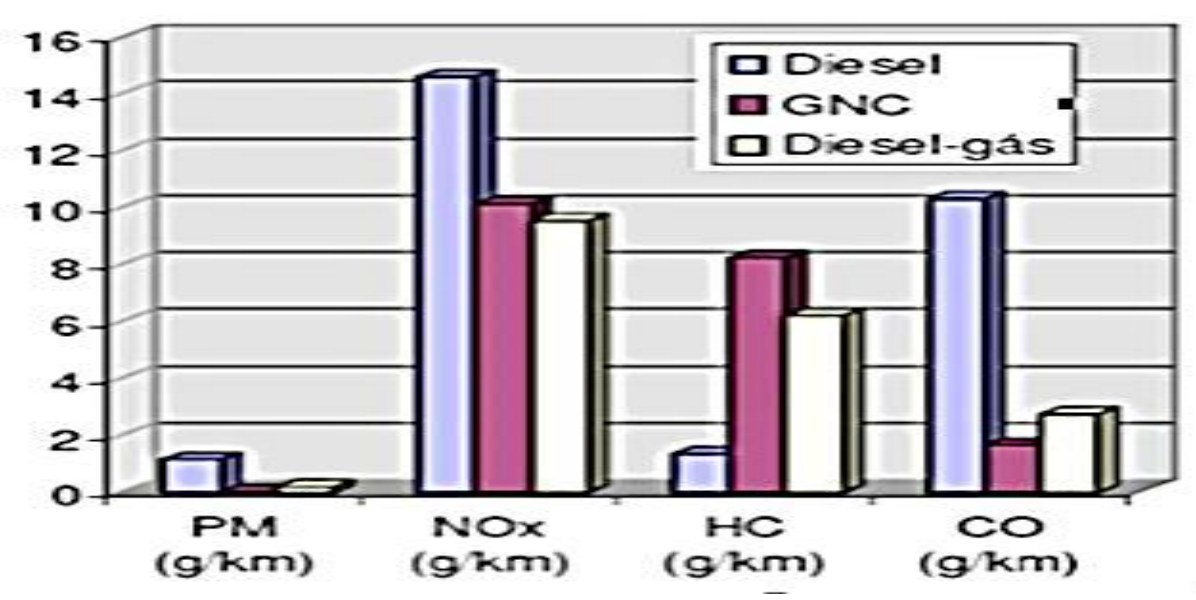

Figura 51 - Comparação da emissão de poluentes em veículos pesados movidos com diesel, gás natural comprimido (GNC) e com a combinação de ambos.

Fonte: André Ricardo, 2007.

A conclusão desse estudo chega à proporção ideal de mistura de $85 \%$ de gás natural e $15 \%$ de diesel, já testada em países como a Rússia e afirma, em termos de questões ambientais, ser o gás natural muito menos poluente que o diesel ou qualquer outro combustível fóssil.

\section{5 .2}

\section{Produção de energia elétrica}

O biogás é utilizado em motores de combustão interna e em turbinas para gerar energia elétrica. A energia é injetada diretamente no grid e também poderá ser aproveitada para abastecer veículos elétricos. (GODLOVE, 2010).

\section{Motores ciclo OTTO}

O motor ciclo OTTO é o equipamento mais utilizado para a queima do biogás, devido ao maior rendimento elétrico e menor custo, quando comparado com outras tecnologias. ICLEI (2009) Para promover a queima do biogás em motores ciclo OTTO, são necessárias pequenas modificações nos sistemas de alimentação, ignição e taxa de compressão. Os motores ciclo OTTO aspiram a mistura antes de ser comprimida no interior dos cilindros e a combustão da mistura é dada por centelha produzida na vela de ignição (Pereira, 2006). Esses motores são chamados de 4 tempos, pois seu funcionamento ocorre 
sequencialmente em quatro etapas. A figura 52 mostra um exemplo de motor ciclo OTTO.

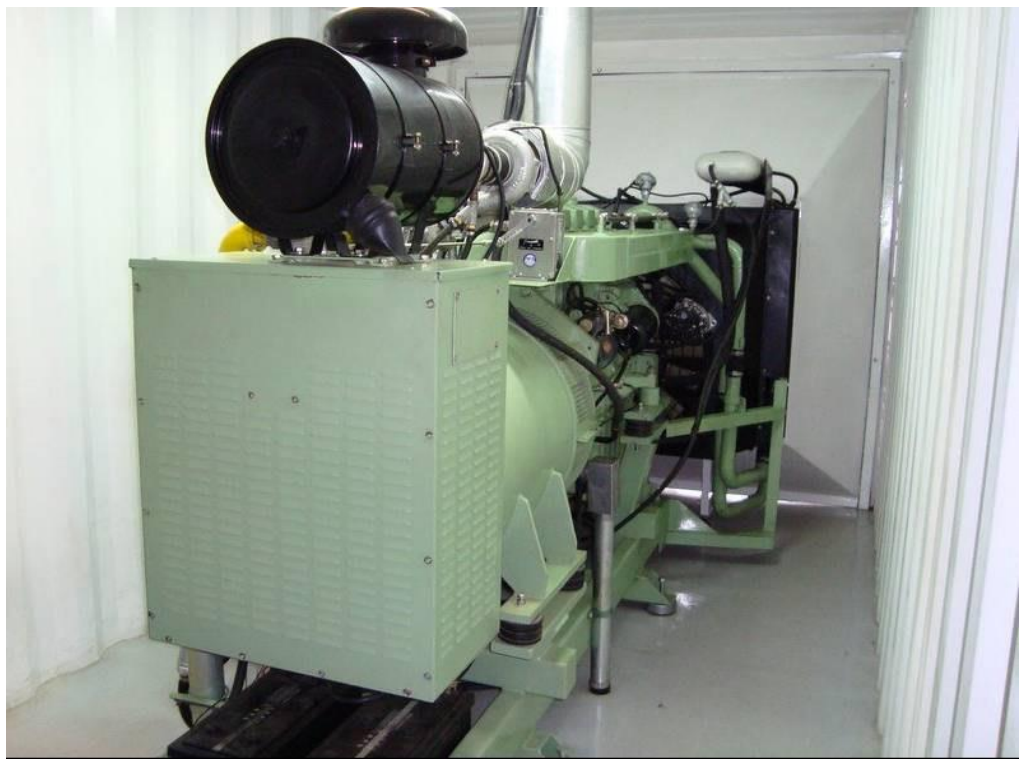

Figura 52 - Motor ciclo Otto adaptado a biogás. Fonte: CENBIO, 2009.

As grandes vantagens desse sistema são:

- Não requer pré-tratamento do biogás.

- Geração de energia elétrica para o próprio consumo.

- Tecnologia comprovada e confiável.

- Possibilidade de obtenção e comercialização de créditos de carbono (considerando $100 \%$ de eficiência de queima).

As maiores desvantagens desse sistema são o baixo rendimento, aproximadamente $28 \%$, altos valores de emissão de $\mathrm{NO}_{\mathrm{x}}$, de grande impacto ambiental. Dependendo do porte do motor, a emissão de $\mathrm{NO}_{\mathrm{x}}$ varia entre 250 e 3.000 p.p.m.

\section{Microturbinas a gás}

Nas microturbinas o ar é inspirado e forçado para o seu interior a alta velocidade e pressão, misturado ao ar/combustível, para então, ser queimado na câmara de combustão. Os gases quentes resultantes da combustão são expandidos 
na turbina e o calor remanescente dos gases de exaustão pode ser aproveitado para aquecimento do ar de combustão. A capacidade menor dessas unidades as torna mais adequadas em aterros mais velhos, menores ou remotos, com baixas taxas de produção de biogás. (BANCO MUNDIAL, 2004). Na figura 53 vê-se uma micro turbina a gás.

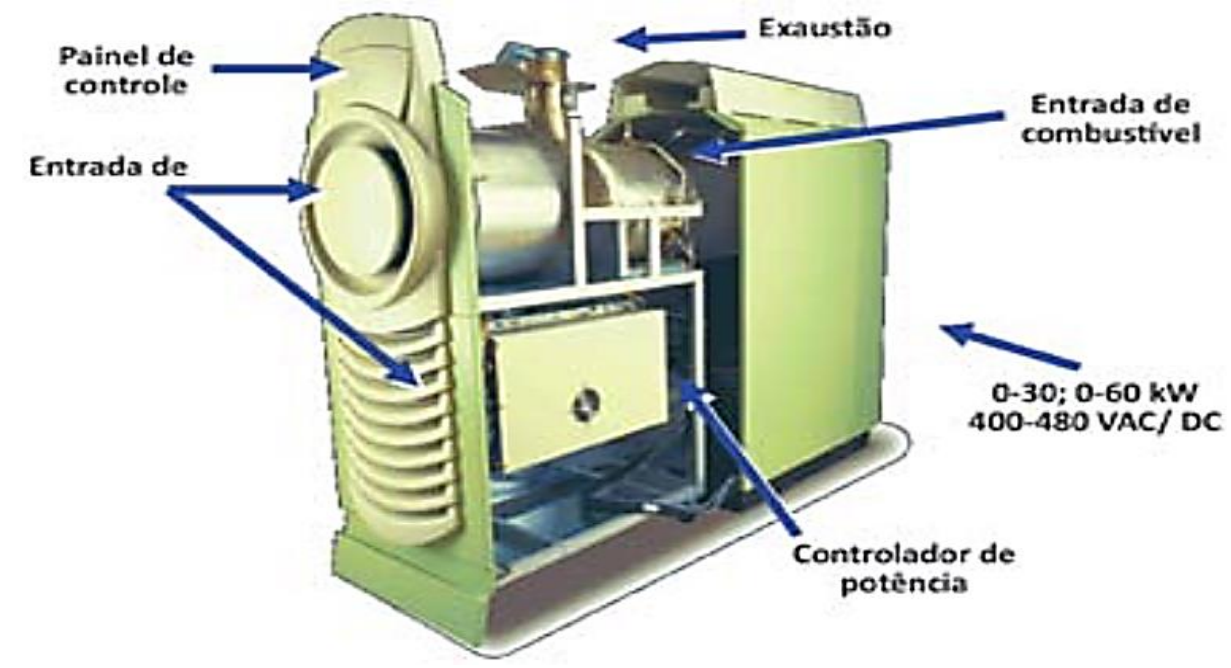

Figura 53 -Desenho esquemático de uma microturbina a gás. Fonte: Monteiro, (2004).

Além das vantagens apresentadas no ciclo OTTO, as microturbinas apresentam os seguintes benefícios:

- Flexibilidade de combustível;

- Baixos níveis de ruídos e vibrações;

- Dimensões reduzidas e simplicidade de instalação, podendo ser instaladas em locais cobertos ou ao ar livre;

- Emissões de $\mathrm{NO}_{\mathrm{x}}$ menores que 9 p.p.m nas micro turbinas de baixa potência (30 a $100 \mathrm{KW})$.

As grandes desvantagens desse sistema é o baixo rendimento de aproximadamente $28 \%$. Porém quando utilizadas em instalações de cogeração, sua eficiência pode chegar a mais de 80\%. (HAMILTON, 2003).

Esse tipo de operação necessita de um rígido sistema de limpeza do biogás e remodelação da microturbina para a sua queima. Isto faz com que a operação e a 
manutenção tenham um alto custo, principalmente quando comparadas a outras tecnologias. A figura 54 ilustra instalações de microturbinas num aterro sanitário.

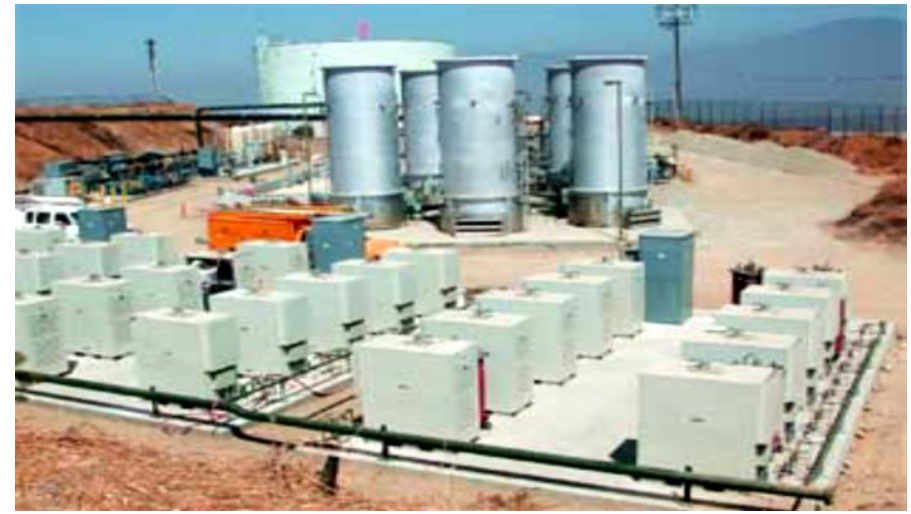

Figura 54 - Instalações com microturbinas em aterros. Fonte: Godlove, 2010.

Os sistemas de microturbinas contêm um compressor, um recuperador, um combustor, uma turbina e um gerador magnético permanente, mas requerem um espaço muito pequeno para operação. (CAPSTONE, 2002).

Dependendo dos combustíveis e tecnologias utilizadas pela usina e do tipo de projeto de aterro sanitário, as reduções de emissões de gases de efeito estufa do aterro podem não compensar a quantidade de $\mathrm{NO}_{\mathrm{x}}$ emitida a partir da geração de eletricidade produzida através do biogás.

Embora o custo de geração de energia das microturbinas seja alto, em comparação com a dos grupos-geradores, sua maior vantagem está diretamente vinculada à questão ambiental, principalmente no que se refere à emissão de $\mathrm{NO}_{\mathrm{x}}$.

\section{5 .3}

\section{Cogeração}

A cogeração é definida como um processo de produção e utilização combinada de calor e eletricidade, proporcionando o aproveitamento de mais de $80 \%$ da energia térmica proveniente dos combustíveis utilizados nesse processo.

Sendo uma tecnologia que permite racionalizar eficazmente o consumo dos combustíveis necessários à produção de energia útil, a cogeração pode assegurar um aproveitamento elevado da energia primária e, por essa razão, responde favoravelmente aos objetivos das políticas energéticas comunitárias e nacionais. 
A cogeração responde também de forma eficaz a preocupações de natureza ambiental, uma vez que ao fornecer a mesma energia final com um menor consumo de energia primária, reduz significativamente as emissões para o ambiente. A cogeração assume assim, um papel muito importante na redução das emissões de $\mathrm{CO}_{2}$. (GODLOVE, 2010). A cogeração ocorre por meio de um ciclo combinado que usa tanto turbina a gás, como turbina a vapor para produzir eletricidade.

A instalação de ciclo combinado num aterro grande, adequado, tem um custo de capital menor por capacidade de MW instalada de produção de energia elétrica, por causa do ganho significativo de eficiência na conversão de energia que pode ser alcançado. Pelo fato ser esta tecnologia bastante onerosa, só é viável em aterros grandes.

Neste ciclo o calor proveniente da combustão de biogás, em uma caldeira, para geração de vapor, é utilizado em processos industriais, aquecimento direto ou na produção de energia elétrica, por meio do acionamento de uma turbina acoplada a um gerador.

O calor do vapor ou da água quente, diferentemente da energia elétrica, não é facilmente transportado por grandes distâncias. Por isso, as unidades cogeradoras devem estar próximas das instalações que utilizam sua energia térmica.

A adaptação dos equipamentos para uso do biogás na cogeração pode ser realizada com pequenas modificações. Para o controle do nível de umidade do gás são utilizados purgadores e linhas de condensado, impedindo, desta forma, danos aos equipamentos e problemas na operação das caldeiras.

\section{Vantagens:}

- O uso de microturbinas em indústrias grandes;

- Maior eficiência energética através da recuperação do calor residual - até $80 \%$;

- Sistemas especializados em cogeração estão disponíveis;

- Flexível - água quente ou geração de vapor a partir do calor recuperado. 


\section{Desvantagens:}

- Maior custo de capital para os sistemas de recuperação;

- Baixo rendimento térmico: aproximadamente 30\%;

- A corrosão. Os compostos presentes no biogás corroem pré-aquecedores de ar, tubulações e outros equipamentos, exigindo adaptação de caldeiras e a manutenção regular para impedir a formação de depósitos de sílica, enxofre e cloro.

\section{5 .4}

\section{A energia elétrica no uso em veículos}

Com a introdução de novas baterias ion-lítio, veículos elétricos preparados para transportar cargas pesadas estão sendo testados na Europa e Estados Unidos. Conforme Erber (2012), o interesse pelo acionamento elétrico dos veículos decorre da prioridade conferida por muitos países à redução de dependência de importações de combustíveis fósseis e à necessidade de reduzir o impacto ambiental de seus meios de transportes. Decorre também da evolução tecnológica das baterias e de seus sistemas de controle, que proporcionam maior autonomia e melhor desempenho do que os que eram alcançados pelos carros elétricos há apenas dez anos. Nos veículos elétricos, a elevada eficiência energética e a redução de emissões são proporcionadas pelas seguintes características:

- Baixo nível de emissões: a geração elétrica necessária para alimentar sua bateria pode implicar em emissões, caso sua fonte primária seja algum combustível fóssil. Mesmo assim, as emissões de uma usina termelétrica tendem a ser menores do que aquelas decorrentes da queima de combustível em um veículo convencional, particularmente se este consumir derivados de petróleo, a menos que a usina seja bastante ineficiente e, sobretudo, se seu combustível for o carvão.

- Todo veículo acionado por motor elétrico pode ter frenagem regenerativa, que recupera parte da sua energia inercial, armazenando-a na bateria, enquanto nos convencionais a frenagem apenas dissipa a energia inercial 
sob forma de calor. $\mathrm{O}$ reaproveitamento de parte da energia fornecida ao veículo é outro fator de aumento da sua eficiência

- Carros a bateria só consomem energia para acelerar e para vencer rampas e resistências inerentes ao movimento. Nada consomem quando parados no trânsito congestionado, enquanto carros convencionais, cujo motor permanece ligado, desperdiçam de $10 \%$ a $15 \%$ do combustível total consumido.

- O motor elétrico apresenta eficiências próximas a $85 \%$ e a bateria, em seus ciclos de carga e descarga, de cerca de $80 \%$, enquanto a dos motores de combustão interna se situa próxima de $30 \%$ e a transmissão mecânica absorve cerca de $10 \%$ da energia do motor.

- Baixa emissão de ruídos.

- O tamanho e o peso do motor são muito menores que os convencionais.

- Vida útil das baterias em torno de 10 anos.

- Custo de manutenção do motor significativamente mais baixo.

Em contrapartida, alinham-se como desvantagens:

- Lento carregamento das baterias.

- Alto custo das baterias

- Descarte das baterias após sua vida útil

- Reservas minerais de lítio ${ }^{7}$, cujas jazidas economicamente exploráveis estão concentradas em poucos países.

\section{6}

\section{Viabilidade econômica do aproveitamento do biogás}

Para Monteiro (2001), o biogás coletado na linha de base é viável por si só. No entanto, é importante destacar que os custos de implantação de um sistema de captação do biogás não são proporcionais à potência a ser instalada.

\footnotetext{
${ }^{7} \mathrm{O}$ lítio das baterias poderá ser recuperado na sua reciclagem, o que remete ao problema tecnológico dessa operação. E, mais, o lítio não é um elemento raro e novas técnicas de sua separação poderão ser desenvolvidas.
} 
O conhecimento da quantidade e da qualidade do biogás gerado em um aterro sanitário de RSU é fundamental para a tomada de decisão quanto à gestão desta emissão gasosa, uma vez que o seu aproveitamento como combustível para produção de energia exige quantidades mínimas para que o investimento seja viável economicamente. ICLEI - LACS (2009). As quantidades vendidas aos clientes são mensuráveis, acordadas em contrato e registradas.

A composição do lixo, especialmente a do material orgânico, é o fator mais importante na determinação do potencial de geração de biogás em um aterro sanitário (Environment Canadá, 1996). Seu conhecimento depende da participação percentual, em peso, dos materiais contidos nos resíduos que são continuamente depositados. Devem ser considerados todos os seus tipos, incluindo, se for o caso, os da construção civil, de podas, de feiras livres, de varrição pública, de serviços de saúde, entre outros. O ideal é possuir essa informação desde o início das atividades do aterro e tentar estimá-la até o momento do seu encerramento.

Outros fatores chaves que influenciam a taxa de produção de biogás incluem: teor de umidade, conteúdo de nutriente, conteúdo de bactéria, nível de $\mathrm{pH}$, temperatura e as características de desenho e funcionamento do aterro sanitário. Quanto maior o aterro e sua profundidade, maior o potencial de emissão de $\mathrm{CH}_{4}$.

Pereira, (2007) ressalta que o Brasil possui, na maior parte do seu território, condições favoráveis para a produção de biogás em aterros sanitários, pelas condições de umidade e temperatura e, principalmente, pela predominância de matéria orgânica na composição dos resíduos sólidos como pode ser visto na figura 55. No país, há mais de 40 aterros que não aproveitam a energia contida no biogás e que poderiam estar explorando o seu potencial energético. 


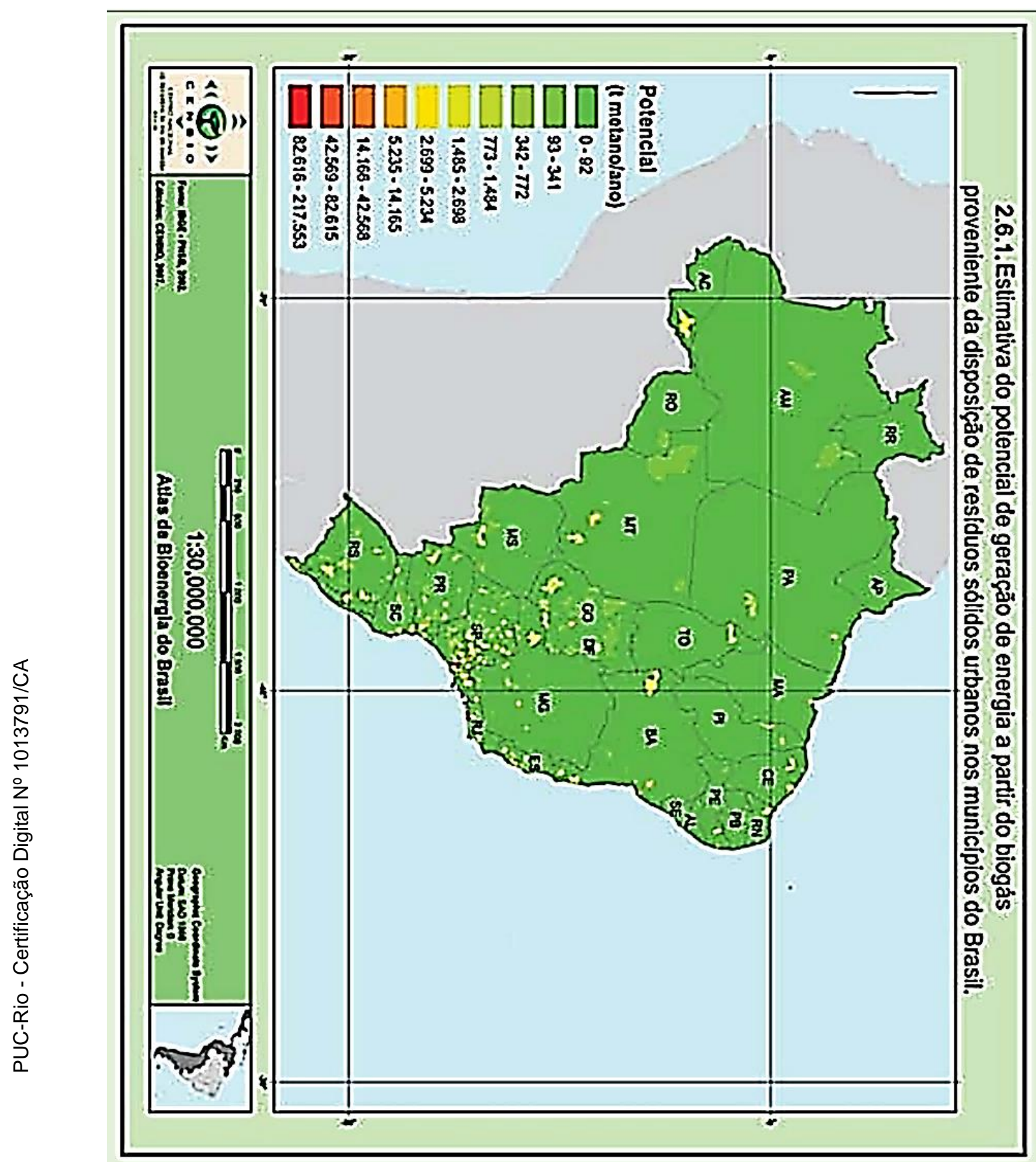

Figura 55 - Estimativa do potencial de geração de energia a partir do biogás proveniente da disposição de RSU nos municípios do Brasil. Fonte CENBIO, 2008.

Para viabilizar mais recursos financeiros para a implantação, operacionalidade e manutenção dos equipamentos para captar o biogás nos aterros sanitários, existe a alternativa de incluí-los nos projetos de MDL (Mecanismo de Desenvolvimento Limpo).

O MDL foi estabelecido a fim de conceder créditos para projetos que reduzam ou evitem emissões nos países em desenvolvimento. Trata-se de um 
mecanismo de grande importância, pois funciona como um canal através do qual os governos e as corporações privadas transferem tecnologias limpas, ao mesmo tempo em que estimula o desenvolvimento sustentável e a redução de emissões. Os créditos são obtidos na forma de Reduções Certificadas de Emissões (RCEs). (FELIPETTO, 2007).

O MDL envolve a compra, pelos países desenvolvidos, de certificados de redução de emissões de carbono (créditos de carbono) dos países em desenvolvimento (que não têm metas de redução de emissões). Assim, por exemplo, a Holanda pode comprar e pagar por créditos de carbono de projetos no Brasil, como forma de auxiliá-la no cumprimento de sua meta de redução.

Esses projetos devem comprovar que reduzem as emissões de gases de efeito estufa para a atmosfera, bem como promovem o desenvolvimento sustentável (MCTI, Ministério da Ciência, Tecnologia e Inovação, 2003).

O interesse na compra de RCE está no fato de que os custos de redução de emissões nos países desenvolvidos podem alcançar valores superiores a US\$ 500 por tonelada de $\mathrm{CO}_{2}$, ao passo que os custos de redução de emissões em países não relacionados no Anexo I do Protocolo de $\mathrm{Kyoto}^{8}$ podem variar de US\$5 a US\$ 30 por tonelada do mesmo gás. Com base nessa diferença de preços criou-se então o Mercado de Redução de Emissões. As quantidades relativas a reduções de emissão de gases de efeito estufa e/ou remoções de $\mathrm{CO}_{2}$ atribuídas a uma atividade de projeto resultam em RCEs medidas em toneladas de dióxido de carbono equivalente.

Os países industrializados possuem cotas de redução de emissões de GEE e, por excedê-las, podem adquirir as RCEs de países em desenvolvimento para flexibilizar o cumprimento de suas metas (CGEE).

Outro fator importante é definir as alternativas da atividade de projeto, bem como as barreiras que impediriam a implementação das mesmas, a fim de escolher a alternativa viável à sua execução.

\footnotetext{
${ }^{8} \mathrm{O}$ protocolo de Kyoto estabelece metas e prazos de compromisso para que as emissões antrópicas dos países desenvolvidos sejam reduzidas em 5\%, na média, em relação aos níveis verificados no ano base de 1990. As metas são diferenciadas entre as Partes1, em consonância com o princípio das responsabilidades comuns, porém diferenciadas, e deverão ser atingido entre 2008 e 2012, primeiro período do compromisso. Essas metas foram atribuídas exclusivamente às Partes relacionadas no Anexo I da Convenção (países desenvolvidos),que assumiram compromisso sem função de suas responsabilidades históricas. Os países que não possuem metas são, em geral, países em desenvolvimento chamados "Países Não Anexo I".
} 
O sistema de captação do biogás varia de eficiência entre 60 a 90\%, quando funcionando em sua capacidade plena. A principal barreira desta atividade é econômica: são os gastos com o sistema, com energia, operação e manutenção da rede de captação. Tudo isto aumenta o custo do aterro.

Com o sistema de extração do biogás e posterior queima em flare, o projeto pode ser inserido no MDL e, consequentemente, obter e comercializar os créditos de carbono.

Além da sua queima em flare, o biogás pode ser utilizado para geração de energia elétrica e térmica, tratamento de chorume, uso veicular e iluminação a gás.

Para a estimativa de redução de emissão de Metano $\left(\mathrm{CH}_{4}\right)$ e a respectiva geração de créditos de carbono, deve-se considerar a vazão total de metano gerado desde o ano de implementação do sistema até, aproximadamente, 15 anos após o encerramento do aterro (considerando o decaimento da emissão após seu encerramento).

Do total de Metano $\left(\mathrm{CH}_{4}\right)$ gerado, estima-se que $60 \%$ será captado pelo sistema de extração e que, deste total, $90 \%$ será oxidado termicamente em um flare com eficiência de queima de $90 \%$. Além disto, para o cálculo dos créditos de carbono é necessário descontar o total de metano atualmente queimado ao ar livre nos drenos de gás existentes. Estima-se que $20 \%$ do total de metano gerado seja queimado nos drenos, portanto, apenas $80 \%$ será passível de geração de créditos.

Para o cálculo da receita obtida anualmente com a venda dos créditos de carbono pode-se considerar US\$ 10,00 a tonelada de carbono (valor bem conservador).

Outra consideração importante a ser abordada na análise econômica é que, em aterros, normalmente as instalações são feitas progressivamente, à medida em que há aumento na produção de biogás.

Conforme a USEPA (1996), dois cenários opostos de produção podem ser usados para dimensionamento do projeto. O primeiro prevê equipamentos que atendam um fluxo mínimo de biogás, garantindo o abastecimento de combustível e promovendo o funcionamento da planta à plena carga por mais tempo. Por outro lado, isso ocasiona a perda de parte do biogás em momentos de produção acima da capacidade de projeto. O segundo cenário prevê equipamentos dimensionados para o máximo fluxo de biogás, considerando assim que a planta funcione em carga parcial e consuma todo o biogás gerado pelo aterro, mas com risco de 
insuficiência de combustível e interrupção na geração de eletricidade. Neste segundo caso o uso de motores de combustão interna é preferível em relação ás turbinas a gás, pois funciona, melhor em carga parcial.

Outra alternativa no dimensionamento de projetos de biogás é o uso de unidades de geração de eletricidade menores que possam ser instaladas ou removidas de acordo com a produção de biogás do aterro. Isso favorece a maximização do uso de biogás e da geração de energia, embora leve ao aumento dos custos de instalação em relação aos projetos modulares. (USEPA, 1996).

A escolha da melhor alternativa a ser implantada em um aterro dependerá diretamente da viabilidade econômica. Nem sempre, a usualmente mais viável é ambientalmente a melhor. (MONTEIRO, 2008).

Este fato pode ser ilustrado pela maioria dos projetos de MDL atualmente implantados, onde se faz apenas a queima do biogás em flare enclausurado, por motivos financeiros, desperdiçando-se o enorme potencial energético.

Como já foi citado antes na explanação dos objetivos do trabalho, a captação e a utilização de biogás é normalmente limitada a grandes e profundos aterros (acima de 1 milhão de tonelada de resíduos e profundidade de mais de 15 metros). No entanto, as condições para cada obra precisam ser analisadas em relação à venda potencial de créditos de carbono, fixação de preço de energia, créditos tributários e outros incentivos "verdes"que possam estar disponíveis. Para projetos de biogás, é também necessária sua potencial ligação a uma rede de energia urbana ou rede de distribuição, ou sua proximidade de algum usuário final de energia (a construção de um gasoduto com esse objetivo especial é, normalmente, limitada a $5 \mathrm{Km}$, isto restringiria aplicações promissoras de biogás de aterros às cidades grandes e intermediárias). (BANCO MUNDIAL, 2004)

$\mathrm{Na}$ fase de avaliação das possibilidades de aproveitamento do biogás, temse disponível normalmente apenas a ordem de grandeza dos investimentos, baseada em experiência de consultores na implantação de projetos similares e cotações preliminares dos equipamentos maiores. (MONTEIRO, 2008).

Para Ensinas (2003), cada instalação de aproveitamento dos gases em aterros tem suas particularidades, dependendo da localização, das necessidades energéticas locais, do investimento financeiro disponível e da legislação vigente, sendo importante a avaliação prévia das diversas possibilidades de aproveitamento. 
Fatores como localização junto a indústrias ou comunidades sem acesso à rede de energia, características de clima e solo, tecnologia disponível, podem definir se a opção de aproveitamento do biogás gerado no aterro é de fato vantajosa do ponto de vista econômico, antes de uma decisão final para o projeto.

A eficiência de captação do biogás do aterro dependerá de vários fatores, como o projeto do aterro, a forma de operação e o clima da região. Na estimativa teórica da quantidade de gás produzido em um aterro devem ser computadas algumas perdas, como, por exemplo, o escape do gás pela camada de cobertura do aterro, as perdas no trajeto do biogás ao longo da rede de drenagem, e as perdas devido a interfaces operacionais e ao nível de chorume.

Para Pereira (2007), o valor da quantidade de metano calculado através dos modelos teóricos, depois de descontados as perdas pela eficiência do sistema de captação, devem ser multiplicados por 21 vezes, que é o valor do carbono equivalente.

\section{Riscos associados a projetos do MDL em resíduos sólidos}

\section{- Risco político}

A gestão de resíduos urbanos, de competência municipal, depende da política do governo local para qualquer solução ou modelo institucional. A troca de governos municipais a cada quatro anos pode trazer descontinuidades fatais para projetos de MDL, que são necessariamente de longo prazo (no mínimo, sete anos).

\section{- Risco da geração e captação de gás}

Nos estudos de viabilidade de créditos de carbono, calcula-se a quantidade de gás gerada por um determinado volume de resíduos sólidos, através de um modelo matemático, e estabelece-se um percentual de sua captação. Tanto a geração, como a captação variam muito, dependendo do tipo de resíduo, da quantidade e, principalmente, do método de operação do aterro e do sistema de gás. Assim, a quantidade de créditos de carbono pode ser significativamente menor do que a estimada e inviabilizar o projeto. 


\section{- Risco de mercado}

Se a oferta de créditos de carbono aumentar e se tornar maior que a demanda, os preços podem cair drasticamente.

\section{- Outros riscos}

Caso a coleta e o tratamento de gás de aterro sanitário no Brasil tornem-se um negócio usual, esses projetos não serão mais elegíveis para o MDL, pois não terão adicionalidade, característica obrigatória para tal elegibilidade. Isto é, fazer o que todo mundo faz usualmente não confere créditos;

Risco GWP (Global Warming Potential) - caso o potencial de aquecimento global do metano seja reestudado e caia para valores significativamente menores que 21, os projetos serão inviabilizados. Especialistas vêm estudando os efeitos dos gases de efeito estufa ao longo dos anos e chegaram ao valor de 21 como o potencial de aquecimento global do metano. No entanto, novas pesquisas continuam sendo executadas, e embora sejam pequenas as chances de isso acontecer, há o risco de que esse número seja alterado, o que, em caso de redução, prejudicaria a viabilidade econômica do projeto e, em caso de aumento, melhoraria os resultados do empreendimento. (FELIPPETO, 2007).

\section{7}

\section{Utilização do biogás de aterros no Brasil}

Em 1985, na cidade do Rio de Janeiro, a companhia de limpeza urbana começou a utilizar o biogás como combustível veicular e chegou a possuir uma frota de cerca de 150 veículos movidos a biogás, além do abastecimento de táxis que também utilizavam este combustível. Este projeto durou cerca de 5 anos (COMLURB, 2011).

Ainda é incipiente, no Brasil, a utilização do biogás de aterros para produção de energia. O incentivo à criação de gestões compartilhadas dos resíduos de vários municípios, conforme a Política Nacional de Resíduos Sólidos, deverá causar um ganho de escala que viabilize não só o aproveitamento de resíduos recicláveis de pequenos municípios, como também a emissão do gás de 
aterro como fonte de energia. A figura 56 exemplifica as alternativas energéticas do biogás coletado nos aterros.

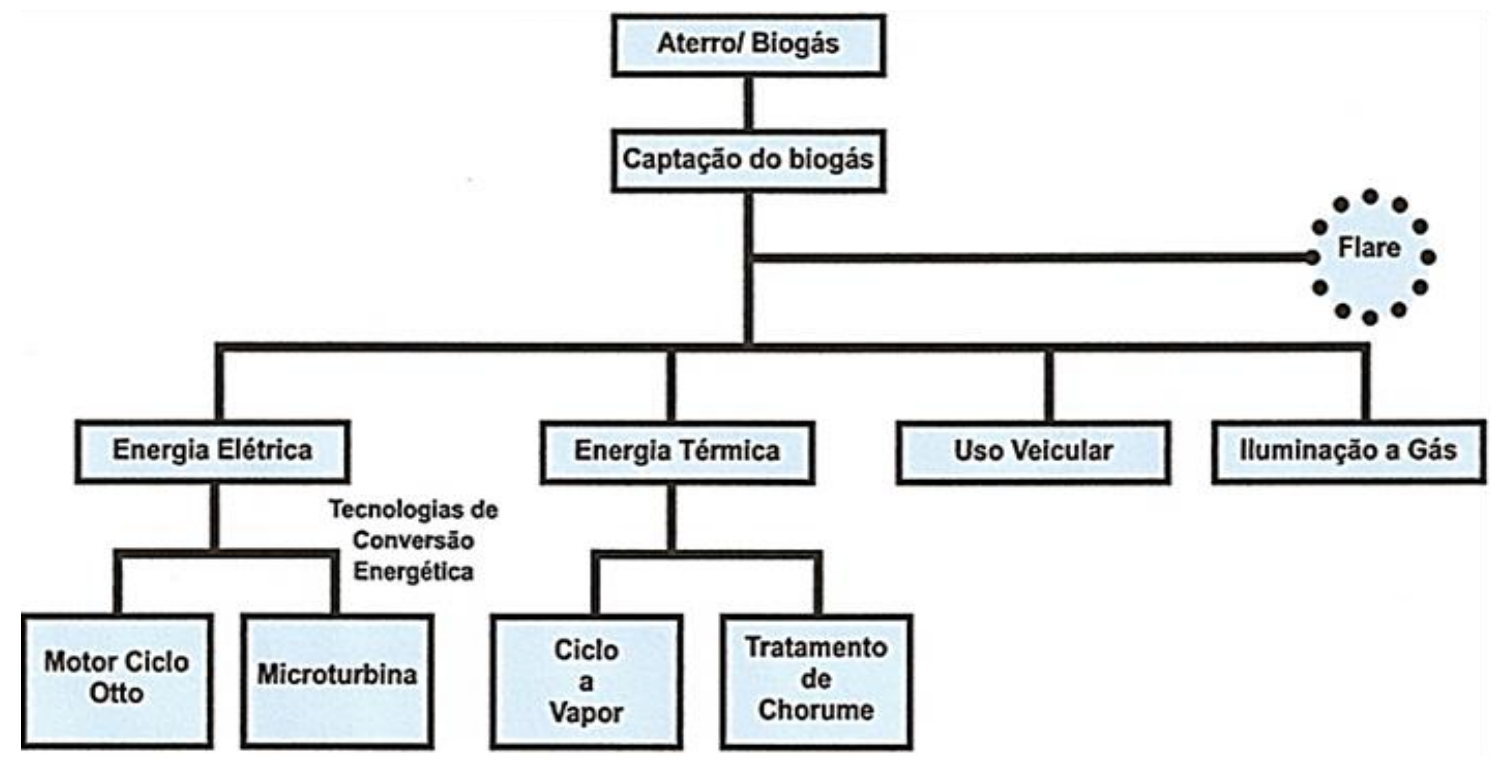

Figura 56 - Diagrama com as alternativas de aproveitamento do biogás.

Fonte: Instituto Agir Sustentável

\section{Aterro Jardim Gramacho, Rio de Janeiro, RJ}

Gramacho operou durante 34 anos, desde 1978 até o dia 03 de junho de 2012, quando oficialmente parou de receber lixo. Durante esse tempo, foi o maior depósito de lixo da América Latina e o principal da área metropolitana do Rio de Janeiro -- a $20^{\mathrm{a}}$ maior do mundo como pode ser vista na figura 57 , com 12,6 milhões de habitantes. Recebeu o lixo dos principais municípios metropolitanos: além do próprio Rio de Janeiro, Niterói, Nova Iguaçu, Duque de Caxias, Petrópolis, Teresópolis, São João de Meriti, Nilópolis, Queimados e Mesquita. Acumulou entre 60 e 80 milhões de toneladas de lixo. (PEGURIER, 2012). 


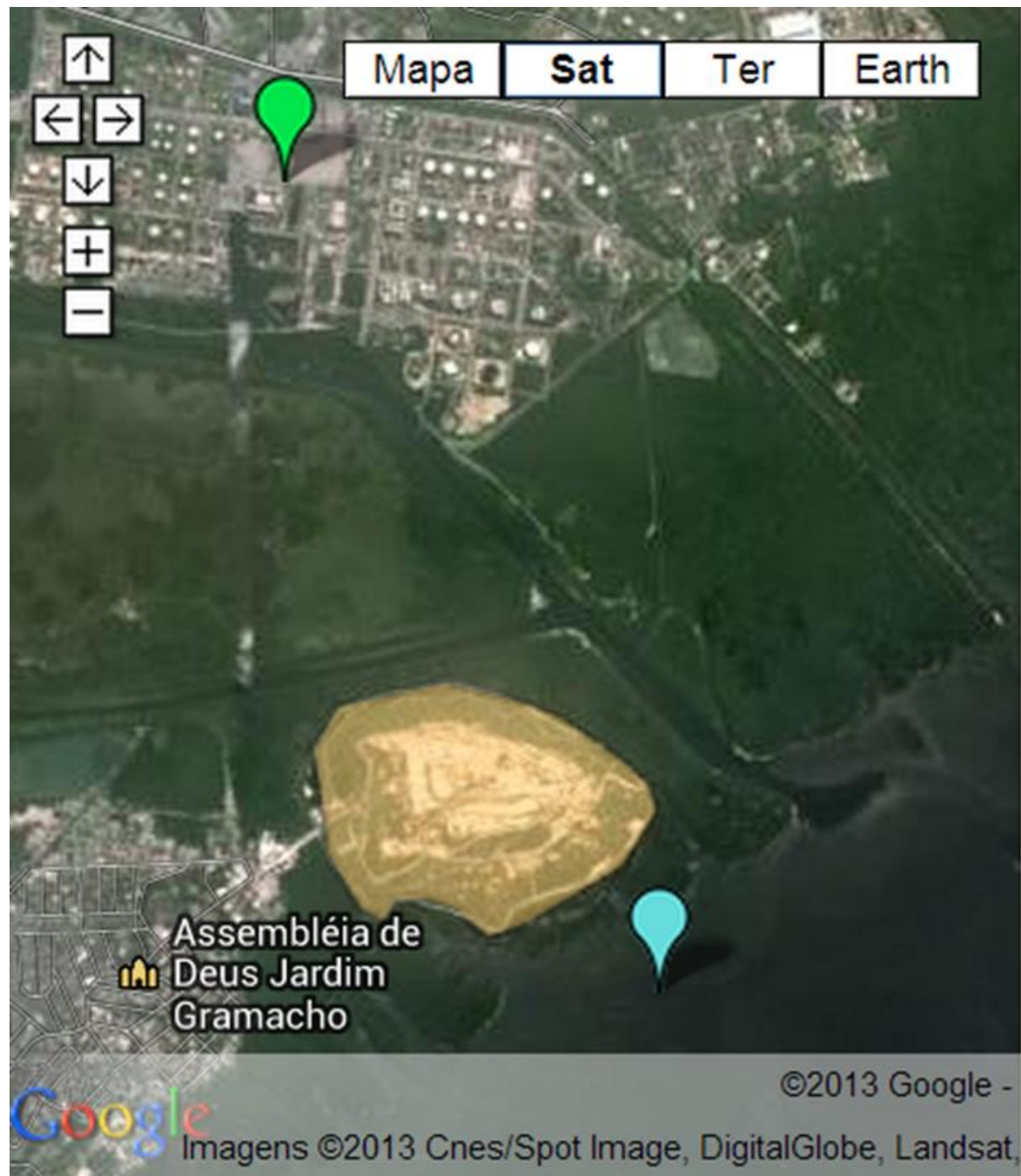

Figura 57 - Vista aérea do aterro Jardim Gramacho/RJ. Fonte: Pegurier, 2012.

Em 2012, foi feito um gasoduto para o transporte do biogás purificado do Aterro Jardim Gramacho até a Refinaria de Duque de Caxias da PETROBRÁS. Esse biogás substituirá parte do uso do gás natural por 20 anos. São $6 \mathrm{Km}$ de

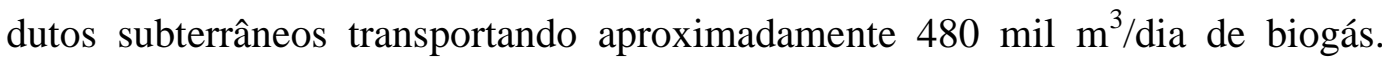
(GÀS VERDE, 2012).

Em 2010, com a inauguração da usina de biogás, iniciou-se sua queima, em alta temperatura em três flares, que são alimentados por uma rede de gasodutos. Esses gasodutos transportarão o biogás de 230 poços de captação localizados em toda a superfície do aterro. Isso evitará que, nos próximos 15 anos, cerca de 75 milhões de metros cúbicos de metano por ano sejam liberados para a atmosfera. O biogás de Gramacho tem aprox. 50\% de metano, com um poder calorífico de aproximadamente $5.000 \mathrm{kcal} / \mathrm{Nm}$. (COMLURB, 2011). 
Seu sistema de exploração do biogás insere-se no Mecanismo de Desenvolvimento Limpo - MDL - previsto no Protocolo de Kyoto, que permite a venda dos créditos de carbono decorrentes das reduções de emissões de gases de efeito estufa para a atmosfera.

Com a redução estimada das emissões em cerca de 6.000.000 t CO eq. para os primeiros 7 anos, o projeto vai assegurar a manutenção do aterro por mais 15 anos após o seu encerramento, dando especial atenção ao seu monitoramento ambiental e geotécnico. (COMLURB, 2011).

\section{Central de tratamento de resíduos, Seropédica, RJ}

A nova Central de Tratamento de Resíduos (CTR), em Seropédica, que vai gradativamente receber os resíduos que iam para o Aterro de Gramacho, está em funcionamento desde 20 de abril de 2011.

$\mathrm{O}$ aproveitamento bioenergético previsto para ser desenvolvido na Central de Tratamento de Resíduos terá capacidade de gerar 30 MW de energia quando o empreendimento estiver em pleno funcionamento. O próprio biogás será utilizado como combustível para os equipamentos que gerarão energia. (COMLURB, 2011).

\section{Aterro Bandeirantes, SP}

Inaugurada em 2003, foi a primeira usina do Brasil a aproveitar o biogás gerado pelo aterro para produzir energia elétrica. Hoje é uma das maiores usinas de energia do mundo com a produção de $12.000 \mathrm{~m}^{3} / \mathrm{h}$ de biogás. Conta com 24 motores com uma capacidade total de $22 \mathrm{MW}$, suficiente para abastecer uma cidade de 400 mil habitantes.

Em setembro de 2007 aconteceu o primeiro leilão de créditos de carbono em bolsa de valores regulada, em âmbito mundial. Os créditos foram obtidos pela Prefeitura de São Paulo com o aproveitamento do biogás do aterro.

No aterro, $80 \%$ do biogás são utilizados na geração de energia elétrica e $20 \%$ restante são queimados em flares. A prefeitura tem direito a $50 \%$ de todo o volume certificado pela ONU, sendo que a outra metade fica com a empresa Biogás, por ter investido no projeto. 


\section{Aterro São João, SP}

A usina inaugurada em 2008 tem também uma alta capacidade 20 MW. Sua produção varia entre $12.000-18.000 \mathrm{~m}^{3} / \mathrm{h}$ de biogás. Conta com 16 motores com uma capacidade de $20 \mathrm{MW}$. Metade dos créditos certificados pela ONU pertence à prefeitura e metade à empresa Biogás. (MONTEIRO, 2009). 
O APROVEITAMENTO ENERGÉTICO DO BIOGÁS DO ATERRO DE JARDIM GRAMACHO NOS CAMINHÕES COLETORES COMPACTADORES DE RSU NA CIDADE DO RIO DE JANEIRO

\section{1}

\section{A capacidade de fornecimento do biogás em relação ao número de caminhões atendidos}

São duas as tecnologias de aproveitamento do biogás a serem abordadas. Assim, para cada uma, utilizou-se uma combinação de dados de entrada, buscando uma solução satisfatória para a demanda de combustível (energia) da frota de caminhões coletores compactadores. A primeira refere-se ao aproveitamento do biogás para a geração de energia elétrica e sua utilização em caminhões elétricos ou híbridos (elétrico/GNV e ou elétrico/diesel): a segunda, em caminhões abastecidos com GNV.

Com base nas informações da COMLURB (2015), a companhia possui 296 caminhões coletores compactadores. A quantidade de lixo recolhida em dezembro de 2014 foi de 184.500 t e a quilometragem média percorrida por veículo foi de $4.160 \mathrm{Km}$. A distância considerada foi total, incluindo os deslocamentos do compactador: garagem/gerência operacional/roteiro de coleta/estação de transbordo, retorno ao roteiro de coleta, transbordo, retorno à garagem. A distância efetiva percorrida em coleta (somente nos roteiros) no turno de operação tem uma variação média de $15 \%$ do total percorrido. O consumo médio dos veículos foi de $1,6 \mathrm{Km} / \mathrm{litro}$. A tabela 30 resume os dados de entrada da coleta de RSU pelos veículos movidos a diesel. 
Tabela 30 - Parâmetros de entrada da coleta COMLURB- Rio de Janeiro, RJ.

\begin{tabular}{|l|c|}
\hline Consumo médio dos coletores compactadores & $1,6 \mathrm{Km} / \mathrm{litro}$ \\
\hline Número de veículos coletores compactadores & 296 \\
\hline Quilometragem média mensal p/ veículo coletor & $4.160 \mathrm{Km}$ \\
\hline Peso total mensal coletado (Dez 2014) & $184.500 \mathrm{t}$ \\
\hline Preço do óleo diesel [1] & $\mathrm{R} \$ 3,08 /$ litro \\
\hline $\begin{array}{l}\text { Produção de biogás do aterro Jardim Gramacho / Rio de } \\
\text { Janeiro (2012) }\end{array}$ & $20.000 \mathrm{~m}^{3} / \mathrm{h}$ \\
\hline
\end{tabular}

[1] Valor do óleo diesel em 15/04/2014 (RJ)

\section{2}

\section{Estimativas de produção de energia elétrica}

A equação 1, abaixo, expressa os parâmetros de entrada para o aproveitamento do biogás como energia elétrica.

$\mathrm{PCS}=5.000 \frac{\mathrm{Kcal}}{\mathrm{m} 3}=5.000 .4,1868 \frac{\mathrm{KJ}}{\mathrm{m3}}=\frac{5.000 .41868}{3600} \frac{\mathrm{Kwh}}{\mathrm{m} 3}=5,815 \mathrm{Kwh} / \mathrm{m}^{3}$

\section{Equação 1}

Onde:

PCS $=$ Poder Calorífico Superior do biogás $=5000 \mathrm{Kcal} / \mathrm{m}^{3}$

$1 \mathrm{Kcal}=4,1868 \mathrm{KJ}$

Supondo que a eficiência do motor seja de $\partial=0,246$

A produção de energia elétrica com o biogás é:

$0,246 \cdot 5,815=1,428 \mathrm{kWh}$

A tabela 31 mostra os dados considerados para calcular o aproveitamento do biogás como combustível na frota de coleta.

Tabela 31 - Parâmetros de entrada para energia elétrica.

\begin{tabular}{|l|l|}
\hline $1 \mathrm{~m}^{3}$ de biogás corresponde & $\mathbf{1 , 4 2 8} \mathbf{~ k W h}$ \\
\hline Consumo de energia caminhão elétrico 16 ton. & $170 \mathrm{kWh}$ \\
\hline Autonomia do caminhão elétrico* & $8 \mathrm{~h} / \mathrm{turno} / 170 \mathrm{Km}$ \\
\hline
\end{tabular}


No caso, porém, para testar a viabilidade da primeira hipótese, utilizou-se esse número de veículos elétricos de 26 t (16 t de peso útil) XXL da PVI (POWER VEHICLE INNOVATION, França), equipado com uma bateria de íonlítio que consome $170 \mathrm{kWh}$ num turno de 8 horas, para coletar resíduos públicos e domiciliares produzidos diariamente no Rio de Janeiro. Desconsiderou-se o fato da coleta domiciliar não ser realizada todos os dias da semana (por toda a frota), a quantidade de resíduos coletada pelos grandes geradores (coleta particular), que o tempo de trabalho de uma guarnição é de 7,33 h e não de 8 h como foi adotado, e que a taxa de geração de lixo pode variar de um ano para o outro, e até mesmo ao longo do ano.

Segundo os valores da Tabela 31, tem-se, no aterro de Gramacho, uma produção diária de $480.000 \mathrm{~m}^{3}$ de biogás (GÁS VERDE, 2012). Com geradores operando com $25 \%$ de eficiência, e observada a correspondência de $1 \mathrm{~m}^{3}$ de biogás $=1,428 \mathrm{kWh}$, sua transformação em energia elétrica produzirá 685.440 kW/dia. Por consequência, a produção mensal será de 20.563 .200 kWh.

\section{Gasto total da frota por turno de $8 \mathrm{~h}$ seria de}

$296 \times 170 \mathrm{kWh}=50.320 \mathrm{kWh} /$ turno

Consumo mensal para abastecer a frota por turno:

$50.320 \mathrm{kWh} /$ turno/dia x $30=1.509 .600 \mathrm{kWh} /$ mês.

Na tabela 32 mostra os parâmetros da produção biogás em relação a seu aproveitamento energético com eletricidade nos veículos de coleta.

Tabela 32 - Aproveitamento do biogás como energia elétrica.

\begin{tabular}{|c|c|c|}
\hline Produção diária aterro & Consumo 8h & Saldo Energético \\
\hline $685.440 \mathrm{kWh}$ & $50.320 \mathrm{kWh}$ & $635.120 \mathrm{kWh} /$ dia \\
\hline Produção mensal & Consumo mensal 8h & \\
\hline $20.563 .200 \mathrm{kWh}$ & $1.509 .600 \mathrm{kWh}$ & $19.053 .600 \mathrm{kWh} / \mathrm{mês}$ \\
\hline $\begin{array}{l}\text { Taxa de aproveitamento } \\
\text { mensal em relação à } \\
\text { produção de biogás aterro }\end{array}$ & & $\mathbf{7 , 4} \%$ \\
\hline
\end{tabular}




\section{3}

\section{Estimativas de produção do GNV}

A segunda hipótese trata do aproveitamento do biogás como GNV, Para efeito de comparação com a hipótese anterior, considera-se sua transformação em energia elétrica equivalente, segundo mostra a equação dois.

$$
\mathrm{PCS}=9.274 \frac{\mathrm{Kcal}}{\mathrm{m} 3}=9274.4,1868 \frac{\mathrm{KJ}}{\mathrm{m3}}=\frac{9274.41868}{3600} \frac{\mathrm{Kw}}{\mathrm{m} 3}=10,786 \mathrm{Kwh} / \mathrm{m}^{3}
$$

\section{Equação 2}

Onde:

PCS $=$ Poder Calorífico Superior do biogás $=5.000 \mathrm{Kcal} / \mathrm{m}^{3}$

$1 \mathrm{Kcal}=4,1868 \mathrm{KJ}$

Supondo-se a eficiência do motor da ordem de $\partial=0,34$, ter-se-á a seguinte produção de energia elétrica com o gás natural:

$$
0,34 \cdot 10,786=3,667 \mathrm{kWh}
$$

Considerou-se a utilização do caminhão $26 \mathrm{t}$ com a transportando 16 toneladas de resíduos (peso útil total), com a capacidade de abastecimento de 126 $\mathrm{m}^{3}$ de gás, sendo que $1 \mathrm{~m}^{3}$ de gás equivalente a 3,667 $\mathrm{kWh}$, corresponderá a $462,04 \mathrm{kWh}$.

Para abastecer a frota, o gasto total seria de:

$$
296 \times 462,04 \mathrm{kWh}=136.763,84 \mathrm{kWh}
$$

Como o rendimento do motor alimentado GNV é maior do que o dos veículos movidos por uma carga elétrica, o volume de $126 \mathrm{~m}^{3}$ seria suficiente para atender a pelo menos 3 turnos de coleta de $8 \mathrm{~h}$ cada um, pois cada caminhão roda cerca de $80 \mathrm{Km}$ em cada turno, fazendo em média $1,9 \mathrm{Km} / \mathrm{m}^{3}$, a autonomia seria de aproximadamente $239,4 \mathrm{Km}$.

\section{Consumo 24 h}

Por cada turno de coleta de $8 \mathrm{~h}=45.587,94 \mathrm{kWh}$ 
A tabela 33 mostra o aproveitamento do biogás com GNV em energia elétrica equivalente.

Tabela 33 - Aproveitamento do biogás com GNV em energia elétrica equivalente.

\begin{tabular}{|c|c|c|}
\hline Produção diária & Consumo 8 h & Saldo Energético \\
\hline $685.440 \mathrm{kWh}$ & $45.588 \mathrm{kWh}$ & $496.465 \mathrm{kWh}$ \\
\hline Produção mensal & $\begin{array}{c}\text { Consumo mensal (60 } \\
\text { turnos 8h) }\end{array}$ & $17.827 .920 \mathrm{kWh} / \mathrm{mês}$ \\
\hline $20.563 .200 \mathrm{kWh}$ & $2.735 .280 \mathrm{kWh}$ & $\mathbf{1 3 , 3} \%$ \\
\hline $\begin{array}{l}\text { Taxa de aproveitamento } \\
\text { mensal em relação à } \\
\text { produção de biogás }\end{array}$ & & \\
\hline
\end{tabular}

\section{4}

\section{Parametrizações dos resultados}

Como o consumo de ambos os caminhões foi considerado de $8 \mathrm{~h}$, falta à transformação para o gasto em 2 turnos de $8 \mathrm{~h}$.

Consumo caminhão elétrico $8 \mathrm{~h}=50.320 \mathrm{kWh} /$ turno. $2=100.640 \mathrm{kWh}$

(Consumo 2 turnos de $8 \mathrm{~h}$ ).

Consumo caminhão GNV 8 h = 91.176 kWh. $2=\mathrm{kWh}$ (Consumo 2 turnos de 8 h). A Tabela 34 abaixo demonstra a comparação dos consumos equivalentes de energia elétrica em 2 turnos de $8 \mathrm{~h}$.

Tabela 34 - Comparação dos consumos equivalentes em 2 turnos de $8 \mathrm{~h}$.

\begin{tabular}{|c|c|c|}
\hline $\begin{array}{l}\text { Consumo GNV 16h/dia } \\
2 \text { turnos } 8 \mathrm{~h}\end{array}$ & $\begin{array}{c}\text { Consumo elétrico } 16 \mathrm{~h} / \text { dia } \\
2 \text { turnos } 8 \mathrm{~h}\end{array}$ & \\
\hline $91.176 \mathrm{kWh}$ & $100.640 \mathrm{kWh}$ & \\
\hline Consumo GNV mensal eq. & Consumo elétrico mensal & \\
\hline $2.735 .280 \mathrm{kWh}$ & $3.019 .200 \mathrm{kWh}$ & \\
\hline $13,3 \%$ & $14,8 \%$ & $\begin{array}{c}\text { Taxa de } \\
\text { aproveitamento } \\
\text { mensal em relação } \\
\text { à produção total de } \\
\text { biogás aterro }\end{array}$ \\
\hline
\end{tabular}




\section{5}

\section{Aspectos econômicos e ambientais}

Alguns dados foram selecionados para serem usados numa extrapolação para a utilização do biogás nos diversos modais dos caminhões coletores. A análise relaciona os seguintes fatores:

- Quantidade de $\mathrm{CO}_{2}$ emitida pelos diferentes tipos de veículos.

- A poluição sonora por eles produzida.

- Gastos poupados com a substituição do diesel pelo biogás ou/ eletricidade.

Por se tratar de apresentação de novas tecnologias que estão começando a serem testadas em países como a França (desde 2011), ressalta-se que o tempo de amostragem pode ainda não ter sido suficiente, para afirmar que o desempenho dos veículos elétricos continuará desta forma. Outra limitação no que diz respeito aos custos é que, quanto maior a frequência, maior o custo total do serviço. Por exemplo, se o veículo coletor recolhe lixo diariamente e não em dias alternados, o custo operacional dobra (mais horas trabalhadas, mais gasto com pneus e combustível, etc.). O número e o tipo de veículos também tem influência direta nos valores dos serviços. A utilização de caçambas com maior capacidade volumétrica é mais econômica, pois assim o caminhão realiza menos viagens e menor será o custo do transporte de RSU.

O comportamento do motorista, condições do veículo, tipo específico de roteiro realizado, acidentes e outras condições também influenciam no consumo de combustível, (custo variável). Vale frisar que este trabalho não avaliou outros componentes ligados aos custos variáveis e fixos, apenas analisou o custo do combustível por tonelada e valor por $\mathrm{Km} /$ consumo de combustível, (que é o custo obtido dividindo-se o valor total de combustível consumido de um período, pela quantidade de lixo coletado, em toneladas, pela distancia percorrida), lubrificantes, filtros, pneus, câmaras, peças de reposição, lavagens, etc., e outros ligados aos custos fixos, tais como depreciação dos veículos (despesa com desvalorização do veículo), remuneração do capital aplicado na frota (estabelece o retorno do investimento na frota), impostos, as taxas e seguros obrigatórios; instalações de equipamentos - prédios, garagens, máquinas, veículos auxiliares e 
móveis; mão-de-obra - direta e indireta (salários, benefícios), todos fazem parte de uma planilha de cálculo do valor do frete. (LIMA, 2014).

A tabela 35 demonstra os benefícios de uma frota de caminhões de coleta movidos a GNV, híbrido e/ ou elétrico sobre o diesel em relação à emissão de $\mathrm{CO}_{2}$ e da poluição sonora.

Tabela 35 - Poluição emitida pelos diferentes modelos de veículos de coleta.

\begin{tabular}{|c|c|c|c|c|c|}
\hline Descrição & Produção & $\begin{array}{l}\text { Produção } \\
\text { mensal } \\
30 \text { dias }\end{array}$ & $\begin{array}{l}\text { Produção } \\
\text { anual }\end{array}$ & $\begin{array}{l}\text { Quantidade } \\
\text { tipo }\end{array}$ & TOTAL \\
\hline \multirow{2}{*}{$\begin{array}{l}\text { Poluição } \\
\text { Emitida por } \\
\text { Veículo diesel }\end{array}$} & \multirow{2}{*}{$\begin{array}{c}1,24 \\
\mathrm{Kg} / \mathrm{CO} 2 / \mathrm{Km} \\
\text { por veículo }\end{array}$} & $\begin{array}{c}4.160 \\
\mathrm{Km} / \mathrm{mês}\end{array}$ & \multirow{2}{*}{$\begin{array}{c}61.900,8 \\
\mathrm{Kg} / \mathrm{CO} 2 / \mathrm{Km} / \mathrm{ano} \\
61,90 \text { t/ano } \\
\text { por veículo }\end{array}$} & \multirow[t]{2}{*}{$\begin{array}{c}296 \\
\text { Veículos }\end{array}$} & \multirow{2}{*}{$\begin{array}{c}18.322 .636,8 \\
\mathrm{Kg} / \mathrm{CO} 2 / \text { ano } \\
18.322,63 \\
\mathrm{t} / \mathrm{CO} 2 / \mathrm{ano}\end{array}$} \\
\hline & & $\begin{array}{c}5.158,4 \\
\mathrm{Kg} / \mathrm{CO}_{2} / \mathrm{Km}\end{array}$ & & & \\
\hline $\begin{array}{l}\text { Poluiçäo } \\
\text { Emitida por } \\
\text { Veículo híbrido } \\
\text { diesellelétrico }\end{array}$ & $\begin{array}{c}-8 \mathrm{t} \\
\text { CO2/ano } \\
\text { em relaçäo } \\
\text { ao diesel } \\
\text { por veículo }\end{array}$ & - & - & $\begin{array}{c}296 \\
\text { veículos }\end{array}$ & $\begin{array}{c}-2.368 \mathrm{t} \text { CO2/ano } \\
15.954,63 \\
\text { t /CO2/ano }\end{array}$ \\
\hline $\begin{array}{l}\text { Poluição } \\
\text { Emitida por } \\
\text { Veículo híbrido } \\
\text { GNVlelétrico }\end{array}$ & $\begin{array}{c}-40 \% \text { em } \\
\text { relaçäo ao } \\
\text { GNV } \\
\text { por veículo }\end{array}$ & $\begin{array}{c}1.372,8 \\
\mathrm{Kg} / \mathrm{CO} 2 / \mathrm{Km}\end{array}$ & $\begin{array}{c}16.473,36 \\
\mathrm{Kg} / \mathrm{CO} 2 / \mathrm{Km} / \mathrm{ano}\end{array}$ & $\begin{array}{c}296 \\
\text { veículos }\end{array}$ & $\begin{array}{c}4.876 .114,56 \\
\mathrm{Kg} / \mathrm{CO} 2 / \mathrm{ano} \\
4.876,11 \\
\mathrm{t} / \mathrm{CO} 2 / \mathrm{ano}\end{array}$ \\
\hline $\begin{array}{l}\text { Poluiçäo } \\
\text { Emitida por GNV }\end{array}$ & $\begin{array}{c}0,55 \\
\mathrm{Kg} / \mathrm{CO} 2 / \mathrm{Km}\end{array}$ & $\begin{array}{c}2.288 \\
\mathrm{Kg} / \mathrm{CO} 2 / \mathrm{Km}\end{array}$ & $\begin{array}{c}27.456 \\
\mathrm{Kg} / \mathrm{CO} 2 / \mathrm{Km} / \mathrm{ano}\end{array}$ & $\begin{array}{c}296 \\
\text { veículos }\end{array}$ & $\begin{array}{c}8.126 .976 \\
\mathrm{Kg} / \mathrm{CO} 2 / \mathrm{ano} \\
8.126,97 \\
\mathrm{t} / \mathrm{CO} 2 / \mathrm{ano}\end{array}$ \\
\hline $\begin{array}{l}\text { Poluiçäo } \\
\text { Emitida por } \\
\text { veículo elétrico }\end{array}$ & $\begin{array}{c}0 \\
\mathrm{Kg} / \mathrm{CO}_{2} / \mathrm{Km}\end{array}$ & - & - & $\begin{array}{c}296 \\
\text { veículos }\end{array}$ & $\begin{array}{c}0 \\
\mathrm{Kg} / \mathrm{CO}_{2} / \mathrm{ano}\end{array}$ \\
\hline $\begin{array}{l}\text { Poluiçäo sonora por } \\
\text { veículo diesel }\end{array}$ & $105(\mathrm{~dB}) \mathrm{A}$ & - & - & - & - \\
\hline $\begin{array}{l}\text { Poluição sonora por } \\
\text { veículo GNV }\end{array}$ & $72(\mathrm{~dB}) \mathrm{A}$ & - & - & - & - \\
\hline $\begin{array}{l}\text { Poluiçäo sonora por } \\
\text { veículo elétrico }\end{array}$ & $O(d B) A$ & - & - & - & - \\
\hline
\end{tabular}

Além do consumo de derivados de petróleo (graxas e óleos lubrificantes), um caminhão compactador ao rodar 1.000 quilômetros na cidade, consome cerca de 625 litros de diesel. Durante o trajeto, lança na atmosfera cerca de 1,24 Kg de $\mathrm{CO}_{2} / \mathrm{Km}$ (ECOFROTAS), além de outros gases poluentes não abordados nesta tabela, enquanto um movido a GNV consegue produzir menos 55,7 \% de $\mathrm{CO}_{2} / \mathrm{Km}$ e um veículo elétrico não emite nada deste poluente por $\mathrm{Km}$. 
A tabela 36 demonstra a produção e o consumo de biogás pela frota de caminhões e o saldo energético com valores para serem disponibilizados na rede de abastecimento. Foram adotados valores médios para o gás natural e para energia elétrica. O MDL também é calculado, pois é uma fonte de receita importante para os investimentos em aproveitamento energético do biogás de aterro e pode ser igualmente medido para a coleta, considerando apenas o $\mathrm{CO}_{2}$ emitido durante um ano de atividade.

Tabela 36 - Valores associados à produção e consumo do biogás.

\begin{tabular}{|c|c|c|c|c|c|c|}
\hline Descrição & $\begin{array}{c}\text { Produção } \\
\text { diária }\end{array}$ & $\begin{array}{c}\text { Produção } \\
\text { mensal }\end{array}$ & $\begin{array}{c}\text { Produção } \\
\text { anual }\end{array}$ & $\begin{array}{c}\text { Quantidade } \\
\text { tipo }\end{array}$ & \multicolumn{2}{|r|}{ TOTAL } \\
\hline $\begin{array}{l}\text { Produçäo de } \\
\text { gás }\end{array}$ & $\begin{array}{c}480.000 \\
\text { Nm3/biogás }\end{array}$ & $\begin{array}{c}14.440 .000 \\
\text { Nm3/biogás }\end{array}$ & $\begin{array}{l}\text { 175.200.000 } \\
\text { Nm3/biogás }\end{array}$ & \begin{tabular}{|c|} 
Saldo \\
energético
\end{tabular} & $\begin{array}{l}\text { Valor } \\
\text { energia }\end{array}$ & $\begin{array}{c}\mathrm{R} \$ \\
330.835 .430,4\end{array}$ \\
\hline \multirow{2}{*}{$\begin{array}{l}\text { Consumo gás } \\
\text { Frota GNV }\end{array}$} & \multirow{2}{*}{$\begin{array}{c}126 \mathrm{Nm} 3 \\
3 \text { ciclos 8h } \\
\text { Por veículo }\end{array}$} & $745.920 \mathrm{Nm} 3$ & $8.951 .040 \mathrm{Nm} 3$ & \multirow{2}{*}{$\begin{array}{c}166.248 .960 \\
\mathrm{Nm} 3\end{array}$} & \multirow{2}{*}{$\begin{array}{c}\mathrm{R} \$ \\
1,99 \mathrm{~m} 3 \\
\text { GNV [1] }\end{array}$} & \\
\hline & & 296 veículos & & & & \\
\hline $\begin{array}{l}\text { Produçäo de } \\
\text { eletricidade }\end{array}$ & $\begin{array}{r}685.440 \\
\mathrm{kWh} / \mathrm{dia}\end{array}$ & $\begin{array}{l}20.563 .200 \\
\mathrm{kWh} / \mathrm{mês}\end{array}$ & $\begin{array}{c}250.186 .600 \\
\text { kWh/ano }\end{array}$ & $\begin{array}{c}\text { Saldo } \\
\text { Energético }\end{array}$ & $\begin{array}{l}\text { Valor } \\
\text { energia }\end{array}$ & $\begin{array}{c}R \$ \\
143.350 .654,00\end{array}$ \\
\hline $\begin{array}{l}\text { Consumo de } \\
\text { eletricidade } \\
\text { Frota elétrica }\end{array}$ & $\begin{array}{c}100.640 \\
\text { kWh/dia } \\
\text { Por veículo } \\
2 \text { ciclos } 8 \mathrm{~h}\end{array}$ & $\begin{array}{c}3.019 .200 \\
\text { kWh/mês } \\
296 \text { veículos }\end{array}$ & $\begin{array}{c}36.230 .400 \\
\text { kWh/ano } \\
296 \text { veículos }\end{array}$ & $\begin{array}{c}213.956 .200 \\
\text { kWh/ano }\end{array}$ & $\begin{array}{c}\mathrm{R} \$ 0,67 \\
\mathrm{kWh} \\
{[2]}\end{array}$ & \\
\hline $\begin{array}{l}\text { Gasto com } \\
\text { diesel }\end{array}$ & $\begin{array}{c}300 \mathrm{I} \\
\text { Diesel/3 d } \\
6 \text { turnos } 8 \mathrm{~h}\end{array}$ & $\begin{array}{c}3.000 \text { I /mês } \\
\mathrm{R} \$ 3,08 / \mathrm{I} \\
{[3]}\end{array}$ & $\begin{array}{l}36.0001 \text { lano } \\
\mathrm{R} \$ 110.880,00\end{array}$ & $\begin{array}{c}296 \\
\text { veículos }\end{array}$ & 32 & $\begin{array}{c}\mathrm{R} \$ \\
.820 .480,00\end{array}$ \\
\hline $\begin{array}{l}\text { Gasto com } \\
\text { óleo lubrif. }\end{array}$ & $\begin{array}{c}30 \mathrm{I}-75 \mathrm{dias} \\
10.000 \mathrm{~km}\end{array}$ & $\begin{array}{c}R \$ 12,00 / 1 \\
{[4]}\end{array}$ & 127 I ano & $\begin{array}{c}296 \\
\text { veículos }\end{array}$ & & $\begin{array}{l}37.592 \text { I } \\
\text { R\$ } \\
51.104,00\end{array}$ \\
\hline $\begin{array}{l}\text { MDL anual } \\
\text { aterro }\end{array}$ & $\begin{array}{c}55 \% \mathrm{CH}_{4} \\
96.360 .000 \mathrm{~m} 3\end{array}$ & $\begin{array}{c}60 \% \text { aprov. } \\
57.816 .000 \\
\mathrm{~m} 3\end{array}$ & $\begin{array}{c}\text { Densidade } \mathrm{CH}_{4} \\
0,717 \mathrm{~kg} / \mathrm{m} 3 \\
41.454 .072 \\
\mathrm{~kg} / \mathrm{m} 3\end{array}$ & $\begin{array}{c}60 \% \text { x } 90 \% \\
\text { Queima em } \\
\text { flare. } \\
41.054 \mathrm{t} \times \\
0,9\end{array}$ & & $\begin{array}{r}.948,66 \mathrm{t} \mathrm{CH}_{42} 20 \% \\
7.389 .72 \mathrm{t} \mathrm{CH} 4 \\
29.558,94 \mathrm{t} \times 21= \\
0.737,74 \mathrm{t} \mathrm{CO} 2 \mathrm{eq} .\end{array}$ \\
\hline $\begin{array}{l}\text { MDL anual } \\
\text { caminhöes } \\
\text { elétricos }\end{array}$ & - & - & $\begin{array}{l}-18.322,63 \\
t / C O 2 / a n o\end{array}$ & - & $\mathrm{t} / \mathrm{CO}$ & $\begin{array}{l}18.322,63 \\
\text { lano x U\$10,00 } \\
\$ 183.226,3\end{array}$ \\
\hline $\begin{array}{l}\text { MDL anual } \\
\text { caminhöes } \\
\text { GNV }\end{array}$ & - & - & $\begin{array}{l}-10.195,66 \\
t / C O 2 / a n o\end{array}$ & - & $\mathrm{t} / \mathrm{CO}_{2}^{-}$ & $\begin{array}{l}10.195,66 \\
\text { lano x U\$10,00 } \\
\$ 101.956,6\end{array}$ \\
\hline
\end{tabular}


[1] valor $\mathrm{m}^{3} \mathrm{GNV}$ em 15/04/2015

[2] valor $\mathrm{kWh}$ em 15/04/2015

[3] valor litro diesel em 15/04/2015

[4] valor litro óleo lubrificante em 15/04/2015

Naturalmente, o dimensionamento dos custos têm grande importância na planilha de uma companhia de coleta. Permite o planejamento dos serviços, com o adequado gerenciamento dos recursos humanos e materiais e, sobretudo, é indispensável à elaboração do orçamento anual dos municípios. Os custos unitários podem ser agregados de acordo com a análise desejada, para se introduzir ou ampliar um serviço de coleta. Estes irão representar o custo final por uma determinada medida. Podem ser: por quilometro, por tonelada coletada, por pessoa atendida, etc.

Para o combustível, o cálculo é simples, basta dividir o preço do combustível pelo rendimento do veículo.

\section{- Custo diesel/Km}

Preço do diesel $=\mathrm{R} \$ 3,081$

Rend. Veículo $=1.60 \mathrm{Km} / \mathrm{l}$

Total veículo a diesel $=\mathrm{R} \$ 1,92 \mathrm{Km}$

- Custo GNV/Km

Preço do GNV $=$ R $\$ 1,99 \mathrm{~m}^{3}$

Rend. Veículo $=1.90 \mathrm{Km} / \mathrm{m}^{3}$

Total veículo movido GNV= R $\$ 1,04 \mathrm{Km}$

- Custo eletricidade /Km

Preço da energia elétrica $=0,67 \mathrm{kWh}$

Rend. Veículo $=1 \mathrm{Km} / \mathrm{kWh}$

Total veículo movido eletricidade $=\mathrm{R} \$ 0,67 \mathrm{Km}$

Para o cálculo por tonelada/Km será:

296 veículos x $4.160 \mathrm{Km} / \mathrm{mês}=1.231 .360 \mathrm{Km} / \mathrm{mês}$

Dividindo o peso total coletado pela quilometragem total percorrida, tem-se:

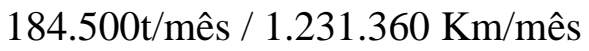


Multiplicando pelo valor do óleo diesel:

0,149 t/Km x R 3,08/l= $\mathrm{R} \$ 0,458$ (custo do óleo diesel consumido para 1 tonelada coletada por $1 \mathrm{Km}$ percorrido no turno).

Multiplicando pelo valor do GNV:

$0,149 \mathrm{t} / \mathrm{Km} \times \mathrm{R} \$ 1,99 \mathrm{~m}^{3}=\mathrm{R} \$ 0,296$ (custo do GNV consumido para 1 tonelada coletada por $1 \mathrm{Km}$ percorrido no turno).

Multiplicando pelo valor da energia elétrica:

$0,149 \mathrm{t} / \mathrm{Km} \times \mathrm{R} \$ 0,67 \mathrm{kWh}=\mathrm{R} \$ 0,09$ (custo do $\mathrm{kWh}$ consumido para 1 tonelada coletada por $1 \mathrm{Km}$ percorrido no turno).

$\mathrm{Na}$ tabela 37, pode-se observar que a estrutura que utiliza motor elétrico é mais econômica, em relação ao consumo de combustível $(\mathrm{Km} / \mathrm{l})$ e ao custo da tonelada de RSU coletada/ distância percorrida $(\mathrm{R} \$ / \mathrm{t} / \mathrm{Km})$. 
Tabela 37 - Custos gerais de veículos. Instalações e rendimento médio dos caminhões.

\begin{tabular}{|c|c|c|c|c|}
\hline Descrição & valor & quant & conversão & TOTAL \\
\hline MDL aterro( anual) & $\begin{array}{c}620.737,74 \text { tCO2 } \\
\text { eq. }\end{array}$ & . & $\begin{array}{c}\text { USS }=10,00 \\
\text { 1USS }=3,03 \\
\text { [1] }\end{array}$ & $\begin{array}{l}\text { US } \$ 6.207 .377,4 \\
\operatorname{RS} 18.808 .353,52\end{array}$ \\
\hline Valor conversão devéículos diese//GNV & $\begin{array}{c}R \$ \\
20.000,00\end{array}$ & 296 & - & $\operatorname{R} \$ 5.920 .000,00$ \\
\hline $\begin{array}{l}\text { Valorveículos híbridos novos 26t(166) } \\
\text { (França). }\end{array}$ & $\begin{array}{c}€ \$ \\
248.000,00 \\
{[3]}\end{array}$ & 296 & $\begin{array}{c}1 \in \$=R \$ 3,24 \\
{[2]}\end{array}$ & $\begin{array}{l}\text { E\$ } 73.408 .000,00 \\
R \$ 237.841 .920,00\end{array}$ \\
\hline $\begin{array}{l}\text { Valor rvéculos diesel nowos 26t(16t) } \\
\text { (França). }\end{array}$ & $\begin{array}{c}€ \$ \\
160.000,00 \\
{[4]}\end{array}$ & 296 & $1 \in \$=R \$ 3,24$ & $\begin{array}{l}\text { E\$ } 47.360 .000,00 \\
\operatorname{R} \$ 153.446 .400,00\end{array}$ \\
\hline $\begin{array}{l}\text { Valorveículos diesel nowos 26t(16t) } \\
\text { (Brasil) }\end{array}$ & $\begin{array}{c}R S \\
370.000 .00\end{array}$ & 296 & . & $R \$ 109.520 .000,00$ \\
\hline Custo instalação aterro gás (Gramacho) & - & $\cdot$ & $\cdot$ & $R \$ 250.000 .000,00$ \\
\hline Consumo diesel R\$ IIKMm & $\begin{array}{c}1 \mid=1,60 \mathrm{Km} \\
{[5]}\end{array}$ & $\cdot$ & $11=R \$ 3,08$ & $\mathrm{R} \$ 1,921 \mathrm{Km}$ \\
\hline Consumo GNV R\$ m3/Km & $\begin{array}{c}1 \mathrm{~m} 3=1,90 \mathrm{Km} \\
{[6]}\end{array}$ & $\cdot$ & $1 \mathrm{~m} 3=\mathrm{R} \$ 1,99$ & $\mathrm{R} \$ 1,04 / \mathrm{Km}$ \\
\hline Consumo elétrico $\mathrm{R} \$ \mathrm{kWh} / \mathrm{Km}$ & $\begin{array}{c}1 \mathrm{kWh}=1 \mathrm{Km} \\
{[7]}\end{array}$ & $\cdot$ & $1 \mathrm{kWh}=\mathrm{R} \$ 0,67$ & $\mathrm{R} \$ 0,48 / \mathrm{Km}$ \\
\hline Custo RS/ tonelada diesel & \multirow{3}{*}{\multicolumn{3}{|c|}{$\begin{array}{c}184,500 \text { t mensal } \\
\text { Dez(2014) }\end{array}$}} & $R \$ 0,458 / t$ \\
\hline Custo R\$I tonelada GNV & & & & $R \$ 0,296 / t$ \\
\hline Custo $\mathrm{RS} /$ tonelada elétrico & & & & $R \$ 0,09 / t$ \\
\hline
\end{tabular}

[1] Cotação do dólar norte americano (US\$) no dia 15/04/2015

[2] Cotação da tonelada de $\mathrm{CO}_{2}=\mathrm{US} \$ 10,00$ (MDL)

[2] Cotação do Euro (€) no dia 15/04/2015

[3] Valor veículo elétrico (26 t) França (OPTIGEDE/ ADEME, 2013) 
[4] Valor veí.culo diesel (26 t) França (OPTIGEDE/ ADEME, 2013)

[5] Consumo diesel (COMLURB, 2015)

[6] Consumo GNV França (OPTIGEDE/ ADEME, 2013)

[7] Consumo elétrico França (PVI, 2013)

O estudo faz uma estimativa da economia de gastos com combustível durante a vida útil do caminhão (baterias previstas para durar em média/10 anos), como pode ser visto na tabela 38 .

Tabela 38 - Valores economizados com a substituição do diesel.

\begin{tabular}{|c|c|}
\hline Projeções futuras & valores \\
\hline Valor do consumo de diesel evitado anualmente & $\mathrm{R} \$ 32.820 .480,00$ \\
\hline Valor do consumo de diesel evitado em 5 anos & $\mathrm{R} \$ 164.102 .400,00$ \\
\hline Valor do consumo de diesel evitado em 10 anos & $\mathrm{R} \$ 328.204,800,00$ \\
\hline Valor da lubrificação evitada anualmente (elétrico) & $\mathrm{R} \$ 451.104,00$ \\
\hline Valor da lubrificação evitada em 5 anos (elétrico) & $\mathrm{R} \$ 2.255 .520,00$ \\
\hline Valor da lubrificação evitada em 10 anos (elétrico) & $\mathrm{R} \$ 4.511 .040,00$ \\
\hline MDL 7 anos (aterro sanitário) & $\mathrm{R} \$ 131.658 .474,64$ \\
\hline $\begin{array}{l}\text { MDL } 7 \text { anos }\left(\mathrm{CO}_{2}\right) \text { caminhões coletores compactadores } \\
\text { elétricos }\end{array}$ & $\mathrm{R} \$ 3.886 .229,82$ \\
\hline MDL 7 anos $\left(\mathrm{CO}_{2}\right)$ caminhões coletores compactadores GNV & $\mathrm{R} \$ 2.162 .499,48$ \\
\hline
\end{tabular}

Estima-se, de maneira conservadora, que a economia com o uso do diesel, caso fosse feita a substituição por eletricidade, seria da ordem de $\mathrm{R} \$$ 328.204.800,00 em 10 anos, ressaltando que a racionalização dos custos da coleta de lixo com combustível além dos custos ambientais evitados, que não foram mensurados neste estudo, pode viabilizar o investimento econômico inicial na incorporação de novos veículos coletores a frota. Evidente que a utilização dessas tecnologias alternativas em substituição ao diesel para os caminhões de coleta, há de se considerar o maior custo de aquisição desses veículos, que ainda não são fabricados no Brasil. Cada um possui caraterísticas diferentes, como tempo de 
abastecimento e operação/manutenção. $\mathrm{O}$ modal elétrico apresenta condições de operação/manutenção mais complexas, pois ainda não existe este tipo de veículo no Brasil. Para carregar as suas baterias, o tempo gasto é de $8 \mathrm{~h}$. Já para o abastecimento de um caminhão GNV é de aproximadamente 15 minutos.

Quanto ao MDL (7 anos) relacionado à coleta, significará um acréscimo de receita, de aproximadamente $\mathrm{R} \$ 3.886 .229,82$ para o modal elétrico e de $\mathrm{R} \$$ 2.162.499,48 para o GNV.

A estratégia e a logística de aproveitamento do biogás e da coleta dos RSU dependerão das características de cada município, de modo que sejam aplicáveis e atingíveis. A avaliação deverá ser orientada por princípios econômicos, sociais e ambientais. É necessário que o conhecimento e a compreensão das etapas de execução dos serviços de limpeza urbana, coleta e transporte dos resíduos, tratamento e disposição final e as tecnologias existentes para cada fase do gerenciamento de resíduos sólidos serão fundamentais na escolha do modelo operacional a ser implantado. Na figura 58, um diagrama dos modelos de exploração do biogás de aterro e suas diferentes opções de aplicação nos caminhões de coleta.

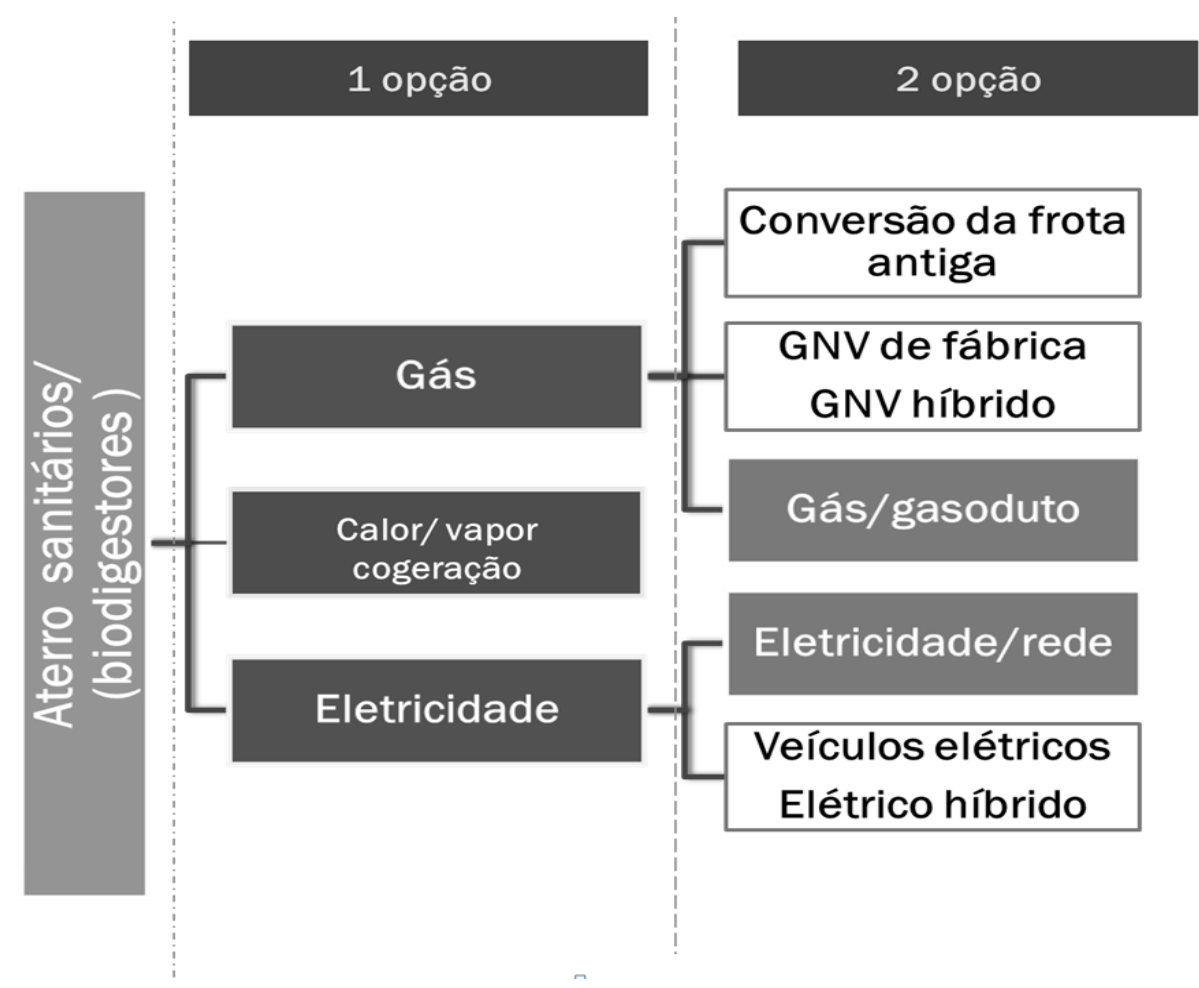

Figura 58 - Diagrama com as alternativas dos modelos de exploração do biogás de aterro e suas diferentes opções de aplicação nos caminhões de coleta. 


\section{CONCLUSÃO}

O trabalho buscou demonstrar que a produção de biogás em Aterros de Resíduos Sólidos Urbanos tais como o de Jardim Gramacho, no Rio de Janeiro, é suficientemente ampla para o abastecimento de uma frota de 296 caminhões coletores de $26 \mathrm{t}$, nas duas rotas tecnológicas abordadas. Deixou certo que a hipótese pode ser replicável em vários municípios brasileiros, desde que tenham possibilidades técnicas e econômicas para implementação de projetos de aproveitamento da energia do gás do lixo, evitando assim gastos com combustível fóssil na coleta de lixo por pelo menos 10 anos (no caso dos veículos elétricos relacionados com a vida útil das baterias), e tendo como consequência direta a redução das emissões de GEE.

Em termos de emissões de $\mathrm{CO}_{2}$, os veículos movidos a GNV emitem menos 44,35\% em comparação aos que utilizam o diesel, já os elétricos apresentam ampla margem em relação aos dois, porque não emitem $\mathrm{CO}_{2}$.

Em relação ao consumo de combustível, o que foi observado em termos de rendimento energético $(\mathrm{Km} / \mathrm{l})$, os elétricos obtiveram desempenho mais eficiente em comparação aos demais modais. Os elétricos ficaram com uma média de R\$ $0,48 \mathrm{Km} / \mathrm{kWh}$ contra os $\mathrm{R} \$ 1,04 \mathrm{Km} / \mathrm{m}^{3}$ do GNV e $\mathrm{R} \$ 1,92 \mathrm{Km} / 1$ do diesel. Os elétricos ainda proporcionam uma economia extra de óleo lubrificante, já que não o utilizam.

$\mathrm{O}$ custo da tonelada coletada pela quilometragem percorrida $(\mathrm{R} \$ / \mathrm{t})$ também aponta uma vantagem significativa de $80 \%$ para o modal elétrico sobre o diesel. O GNV obteve uma redução de 35,5\% sobre o custo do diesel.

No caso da poluição sonora, os veículos movidos a GNV produzem ruídos altos, cerca de $72(\mathrm{~dB})$ A, superiores aos $50(\mathrm{~dB})$ A estabelecidos como máximo tolerado sem causar incômodos à população, principalmente se essa exposição aos ruídos ocorrer durante as coletas noturnas (apesar de serem bem mais silenciosos que os 105(dB) A emitidos pelos caminhões a diesel). Os movidos à eletricidade apresentam o beneficio de não produzirem qualquer ruído. Os únicos ruídos que podem vir a acontecer serão os provocados pelo manuseio dos contêineres pelos garis. 
Por se tratar da apresentação de resultados preliminares, como limitante da pesquisa, destaca-se que a opção que obteve o maior índice de aproveitamento do biogás como fonte de energia foi com os veículos que utilizam o GNV, porém muito próximo aos movidos a eletricidade. Os resultados demonstraram que com apenas $13,3 \%$ do total do gás que é coletado mensalmente seria suficiente para o abastecimento da frota de veículos coletores compactadores da COMLURB, ainda restando $86,7 \%$ para ser comercializado e injetado na rede de abastecimento.

Quanto à utilização da energia elétrica, vai corresponder ao total de 14,8\% da eletricidade que está sendo gerada e também poderá disponibilizar os 85,2\% restantes para serem comercializados e injetados na rede.

A capacidade de fornecimento de biogás ultrapassa com boa margem o número de caminhões atendidos e permite até uma projeção futura de autosuficiência para o abastecimento da frota, mesmo com o provável aumento da geração de lixo e consequentemente, a necessidade do acréscimo do número de veículos. O que este trabalho não avaliou foram as variáveis ligadas a possíveis mudanças na produção de biogás ao longo do tempo, para poder afirmar que o aterro continuará com o grande volume de biogás gerado. Para novos aterros, que possuam o controle do tipo de resíduos que são depositados, serão necessários estudos de modelagem para a projeção futura da geração de biogás.

Frente às necessidades de energia no âmbito nacional e global, a exploração comercial do biogás pode ser uma alternativa sustentável para os RSU dos aterros sanitários, aumentando a oferta de energia elétrica e de gás, e também principalmente pela frágil infraestrutura energética brasileira, cada vez mais sujeitas à apagões.

Uma escolha intermediária em termos de custo/beneficio seria a conversão dos caminhões mais antigos de coleta movidos a diesel para diesel/GNV, possibilitando assim uma renovação parcial da frota. Estrategicamente para o Brasil é interessante à aplicação controlada do GNV em veículos pesados em substituição parcial ao diesel, pois o país possui uma das maiores frotas de veículos movidos a GNV, permitindo uma logística melhor em termos de abastecimento e manutenção.

Além das opções relacionadas, existem outras combinações de veículos híbridos atuando em países europeus, como GNV/elétrico, diesel/elétrico e diesel/ GNV, que também poderão ser empregadas. 
A alternativa de veículos movidos a GNV é perfeitamente aplicável à realidade das grandes cidades brasileiras, mas, no caso dos RSU, com a saturação do trânsito, seu desempenho fica comprometido em relação ao consumo. Já que o mesmo não acontece com os veículos elétricos, que só gastam energia quando estão em movimento. Do ponto de vista ambiental, a mobilidade elétrica é a mais indicada, pois ganha significativa importância no conceito de trânsito, com eficiência energética para o desenvolvimento sustentável. É previsível que venham a serem nelas criadas zonas de emissões zero tanto de gases quanto de ruídos.

Como o volume de trânsito nas ruas continua a aumentar a um ritmo mais rápido que a capacidade da malha viária, e os congestionamentos causam problemas cada vez maiores, dependendo do estágio de lentidão do trânsito, os órgãos responsáveis pela limpeza urbana cada vez mais terão dificuldades para executar os serviços que lhes competem, deixando parte do lixo disposto sem ser recolhido.

Como consequências, podem ser citadas:

- atraso nos roteiros de coleta, alongando a exposição do lixo nas ruas;

- aumento do tempo improdutivo da guarnição de trabalhadores parados aumento do custo de transporte;

- redução da produtividade dos caminhões de coleta, que são veículos especiais e caros;

- aumento das emissões veiculares de gases de efeito estufa.

Em futuro próximo, as coletas, principalmente as domiciliares/ públicas, deverão ser realizadas cada vez mais em turnos noturnos, executadas por caminhões elétricos e/ou híbridos/elétricos, que por produzirem menos ruídos, mostram-se os mais indicados para realização da tarefa com melhor qualidade de vida da população.

De qualquer maneira, uma vez definida qual a tecnologia para a utilização do biogás como combustível nos caminhões de coleta de RSU, os resultados serão: 
- Redução nos custos operacionais de coleta e na destinação final dos RSU;

- Diminuição dos impactos ambientais;

O biogás, captado nos aterros sanitários e transformado em combustível para os caminhões de coleta dos RSU expande a vida destes resíduos e dá origem a um sistema onde o que seria o fim do ciclo de vários produtos passa a ser o início de uma nova etapa, como fonte de energia a ser utilizada na sua própria coleta.

O sistema de limpeza urbana seria projetado como ecossistema do lixo por analogia aos ecossistemas biológicos. Os uniformes dos garis, cestas coletoras, papeleiras, sacos plásticos, vassouras (feitas com madeira certificada), e diversos outros itens poderiam ser feitos de materiais reciclados. Com isso, os sistemas de limpeza ganhariam a configuração de circuitos quase que inteiramente fechados; criariam novo uso para os materiais descartados, e assim incentivariam a população a se adaptar a novos padrões e a práticas de consumo mais sustentáveis.

No caso das emissões evitadas pelo novo sistema de coleta, possibilita a estimação de um ganho associado aos créditos de carbono estabelecidos pelo protocolo de Kyoto, por exemplo. Um sistema que gera energia elétrica a partir do biogás de aterro para abastecer caminhões de coleta de lixo é inédito no mundo. 


\section{REFERÊNCIAS BIBLIOGRÁFICAS}

ABETRE Associação Brasileira de Empresas de Tratamento de Resíduos. Caminhões de lixo são os que mais emitem dióxido de carbono. Ziegler, Maria F., 2012.

ABRELPE Associação Brasileira de Resíduos Sólidos e Limpeza Pública. Biogás produzido em aterros sanitários - aspectos ambientais e aproveitamento do potencial energético Redução de emissões na disposição final. (Mecanismo de desenvolvimento limpo aplicado a resíduos sólidos). 2005. Disponível em: $\langle$ http://www.abrelpe.org.br/_download/informativo_recuperacao_energetica.pdf $>$

Acesso em: 15 jul. 2012.

AD-NETT Anaerobic Digestion of Agro-Industrial Wastes: Information Networks. Technical Summaryon Gas Treatment. Netherlands, 2000. 31p.

ANDRÉ R. L T., RODRIGO DE A MAGGIONI, TANAKA Gustavo A; RENATO BATTOCHIO MAZZIERO Estudo da viabilidade ecológica e financeira da substituição do diesel por GNV para a frota de caminhões e ônibus em Campinas. Graduação, Faculdade de Engenharia Mecânica, UNICAMP, 2007.

Armazém de Dados da Prefeitura do Rio de Janeiro Plano de Ação para a Redução de Emissões dos Gases de Efeito Estufa da Cidade do Rio de Janeiro. COPPE/UFRJ. (2005)

Disponível em: <http://www.armazemdedados.rio.rj.gov.br/arquivos/3060_plano\%20de\%20a\%C3\%A7\% C3\%A3o\%20para\%20a\%20redu\%C3\%A7\%C3\%A3o\%20de\%20emiss\%C3\%B5es\%20d os $\% 20$ gases $\% 20 \mathrm{de} \% 20$ efeito $\% 20$ estufa $\% 20 \mathrm{da} \% 20$ cidade $\% 20 \mathrm{do} \% 20$ rio $\% 20 \mathrm{de} \% 20$ janeir o.PDF> Acesso em: 12 dez. 2012.

BAHÉ, J.M.C.F.; VERÓL, A.P.; ALVES, L.V.; CANTANHEDE, A.; FIGUEIREDO, I.C. Estudo do desempenho de evaporador unitário como opção de tratamento de lixiviados produzidos em aterros sanitários do Rio de Janeiro. Trabalho apresentado no $24^{\circ}$ Congresso Brasileiro de Engenharia Sanitária e Ambiental. Belo Horizonte/MG; 2007.

BARAN, R. A introdução de veículos elétricos no Brasil: avaliação do impacto no consumo de gasolina e eletricidade. Tese de Doutorado apresentada ao Programa de Planejamento Energético, COPPE/UFRJ, 2012.

BARROS, F.V. Aliar maior potência a menos consumo é o desafio do futuro. Folha de São Paulo em 25/04/2013 Disponível em: <http://classificados.folha.uol.com.br/veiculos/2013/04/1268124-aliar-maior-potencia-amenos-consumo-e-o-desafio-do-futuro.shtml>. Acesso em 23 mar. 2014.

BHAT, V.N. A model for the optimal allocation of trucks for the solid Waste Management and Research, 14:87-96, 1996.

BANCO MUNDIAL Manual para a preparação de gás de aterro sanitário para projetos de energia na América Latina e Caribe. (2004). Waterloo, Ontario. Disponível em: 〈http://w.worldbank.org〉. Acesso em: 24 nov. 2012. 
BIODIESELBR Biogás em Aterros Sanitários. Disponível em: <http://www.biodieselbr.com/energia/biogas/biogas-aterros-sanitarios.htm〉. Acesso em: 12 ago. 2012.

BIODIESELBR Biodigestor. Disponível em: < http://www.biodieselbr.com/energia/biogas/biodigestor.htm> Acesso em: 13 abr. 2012.

BLOG ACESSIBILIDADE NA PRÁTICA Obras x Acessibilidade. Disponível em:

$<$ http://acessibilidadenapratica.blogspot.com.br/2011/06/obras-X-acessibilidade.html $>$.

Acesso em: 12 dez. 2012.

BLOG DO CAMINHONEIRO MAN desenvolve caminhão híbrido "Plug-in". Disponível em: <http://blogdocaminhoneiro.com/2012/08/man-desenvolve-caminhaohibrido-plug-in/>. Acesso em: 16 dez. 2013.

BONFIGLIOLI, Gustavo O lixo mais rápido da Europa, Jornal O Estado de São Paulo Disponível em: $<$ http://www.estadao.com.br/noticias/vidae,o-lixo-mais-rapido-daeuropa,644624,0.htm>. Acesso em: $15 \mathrm{dez} 2013$.

BORBA, Silvia M.P. Análise de Modelos de Geração de Gases em Aterros Sanitários: Estudo de Caso [Rio de Janeiro] XV, 134 p. 29,7 cm. COPPE/UFRJ, Dissertação Universidade Federal do Rio de Janeiro, 2006.

BRAGA, José Olavo Nogueira [et al.];. O Uso do Geoprocessamento no Diagnóstico dos Roteiros de Coleta de Lixo da Cidade de Manaus. 2008.

BRASIL. Empresa de Pesquisa Energética. Balanço Energético Nacional (BEN 2011)Ano base 2010: Resultados Preliminares. Rio de Janeiro: EPE. Disponível em: $\langle$ https://ben.epe.gov.br/downloads/Resultados_Pre_BEN_2011.pdf $>$. Acesso em 28 nov. 2012.

BRASIL, Ministério da Ciência, Tecnologia e Informação (MCTI) Inventário de Emissões e Remoções Antrópicas de Gases de Efeito Estufa não Controlados pelo Protocolo de Montreal, (1996). Disponível em: <http://www.mct.gov.br/upd blob/0004/4199.pdf〉. Acesso em 28 nov. 2012.

BRASIL, Ministério do Meio Ambiente (MMA) Aproveitamento Energético do Biogás de Aterro Sanitário. Disponível em: <http://www.mma.gov.br/cidadessustentaveis/residuos-solidos/politica-nacional-de-residuos->. Acesso em: 15 abr. 2012.

BRASIL, Ministério do Meio Ambiente (MMA) $1^{\circ}$ Inventário Nacional de Emissões Atmosféricas Por Veículos Automotores Rodoviários, 2011, Secretaria de Mudanças Climáticas e Qualidade Ambiental Diretoria de Mudanças Climáticas, disponível em: <http://www.mma.gov.br $>$. Acesso em: 15 abr. 2012.

BRASIL, Ministério do Meio Ambiente (MMA) Qualidade do ar. Disponível em: <http://www.mma.gov.br/cidades-sustentaveis/qualidade-do-ar>.Acesso em: 18 abr. 2012.

BRASIL, Política Nacional de Resíduos Sólidos. Disponível em:http://www.planalto.gov.br/ccivil 03/ ato2007-2010/2010/lei/112305.htm.. Acesso em: 4 nov. 2012. 
CEBDS Conselho Empresarial Brasileiro para o Desenvolvimento Sustentável Mudanças Do Clima Podem Causar Insegurança Energética. SPITZCOVSKY, Débora- Planeta Sustentável - 10 abr. 2013. Disponível em: $<$ http://planetasustentavel.abril.com.br/noticia/energia/mudancas-climaticas-insegurancaenergetica-queda-producao-hidreletricas-738296.shtml>. Acesso em: 22 nov. 2013.

CEMPRE - Compromisso Empresarial para Reciclagem. Pesquisa Ciclosoft. Disponível em: < http:// www.cempre.org.br/ciclosoft 2008.php.> Acesso em: $15 \mathrm{dez}$. 2012.

CENBIO - Centro Nacional de Referência em Biomassa. Relatório de Atividades Visita a Aterros Sanitários. Projeto: Aproveitamento do Biogás Proveniente do Tratamento de Resíduos Sólidos Urbanos para Geração de Energia Elétrica e Iluminação a Gás.

CETESB--Companhia Ambiental do Estado de São Paulo Relatórios de referência. Primeiro inventário brasileiro de emissões antrópicas de gases de efeito estufa. Companhia de Tecnologia de Saneamento Ambiental (2006). Disponível em: $<$ http://www.cetesb.sp.gov.br/userfiles/file/mudancasclimaticas/proclima/file/publicacoes /residuos/portugues/15.pdf $>$. Acesso em: 23 jan. 2012.

CETESB- Companhia Ambiental do Estado de São Paulo Aterro Sanitário. Disponível em: 〈http://www.cetesb.sp.gov.br〉 Acesso em 23 jan. 2012.

CETESB-- Companhia Ambiental do Estado de São Paulo Relatórios de referência segundo inventário brasileiro de emissões antrópicas de gases de efeito estufa emissões de dióxido de carbono por queima de Combustíveis: abordagem Topdown. (2010). Disponível em: $<$ http://www.cetesb.sp.gov.br/userfiles/file/mudancasclimaticas/geesp/file/docs/publicaca o/nacional/2_comunicacao_nacional/rr/energia/brasil_mcti_topdown.pdf $>$. Acesso em: 23 abr. 2012.

CIMM - Centro de Informação Metal Mecânica Impacto Ambiental. Disponível em: 〈http://www.cimm.com.br/portal/material_didatico/7561-pactoambiental\#.UqoewsRDt8F Centro de informação Metal mecânica. >. Acesso em: 13 mar. 2012.

COELHO, S.T. Mecanismos para implementação da cogeração de eletricidade a partir de biomassa. Um modelo para o estado de São Paulo. USP, 1999.

COELHO, S.T.; MONTEIRO, M.B.; KARNIOL, M.R.; GHILARDI, A.N. Atlas de Bioenergia do Brasil - São Paulo. Projeto Fortalecimento Institucional do CENBIO, 2005.

COELHO, S.T.; STORTINI, S.M.; VELÁZQUEZ, G;MARTINS, O.S. Eng. Fernando Castro de Abreu. A conversão da fonte renovável biogás em energia. 2009.

COMLURB Companhia de Limpeza Urbana O destino final dos resíduos removidos no Rio de Janeiro em 2011. Disponível em:<http://www.rio.rj.gov.br/web/comlurb.>

Acesso em: 15 mar. 2012.

COMLURB Companhia de Limpeza Urbana Potencial energético do biogás de aterros Disponível em: 〈http://comlurb.rio.rj.gov.br/potencial bio gas.htm>. Acesso em: 11 jan. 2012. 
COMLURB Companhia de Limpeza Urbana Informações técnicas obtidas junto ao funcionário Renato Simões da diretoria Técnica e de Logística (DTI), 2015.

D'ALMEIDA, M. L. O. \& Vilhena, A. (2000). Lixo municipal: Manual de gerenciamento integrado. IPT/CEMPRE, São Paulo, 2 edição.

DEGANUTTI, Roberto, PALHACI, Maria do Carmo Jampaulo Plácido, ROSSI, Marco et al. Biodigestores rurais: modelo indiano, chinês e batelada. In Anais do $4^{\circ}$ Encontro de Energia no Meio Rural, 2002, Campinas (SP). Disponível em: $<$ http://www.proceedings.scielo.br/scielo.php?script=sci_arttext\&pid=MSC00000000220 02000100031\&lng=pt\&nrm=iso $>$. Acesso em: 11 ago. 2012.

EBAH Lenzandrellenz, André Luis Veículos elétricos movidos a eletricidade. Disponível em: <http://www.ebah.com.br/content/ABAAAfOLEAI/veiculosautomotivos-movidos-a-eletricidade?part=8>. Acesso em: 22 nov. 2013.

ECOFROTAS Disponível em: < https://www.ecofrotas.com.br/site/>. Acesso em: 15 abr. 2012.

ENERGIA Panorama energético atual e perspectivas futuras. Disponível em: <http://www.biodieselbr.com/energia/alternativa/agro-energia.htm>. Acesso em: 25 nov. 2011.

ENSINAS, A.V. Estudo da geração de biogás no aterro sanitário Delta em Campinas. - Dissertação (Mestrado) - Universidade Estadual de Campinas, Faculdade de Engenharia Mecânica, Campinas, SP, 2003.

ENSP - ESCOLA NACIONAL DE SAÚDE PÚBLICA SERGIO AROUCA. Disponível em: 〈http://www.ensp.fiocruz.br/portal-ensp/> Acesso em: 30 de out. 2012.

ERBER, PIETRO Carro elétrico: vantagens e equívocos. Disponível em: $<$ http://www.ambienteenergia.com.br/index.php/2012/02/carro-eletrico-vantagens-eequivocos/17145>. Acesso em: $10 \mathrm{dez} .2013$.

ESSENCIS SOLUÇÕES AMBIENTAIS. Imagem disponibilizada pela Central de Tratamento de Resíduos de Caieiras/São Paulo, 2009.

FARIA, M. Biogás produzido em aterros sanitários - aspectos ambientais e aproveitamento do potencial energético. Instituto de Eletrotécnica e Energia da Universidade de São Paulo (USP) São Paulo, 2010.

FELIPETTO, A.V.M. Avaliação de concessionária de tratamento de resíduos com opções reais. Dissertação (Mestrado)-IBMEC, Rio de Janeiro, 2005.

FELIPETTO, A.V.M. Mecanismo de desenvolvimento limpo aplicado a resíduos sólidos. Conceito, planejamento e oportunidades . Rio de Janeiro: IBAM, (2007). 40 p 40 p. $21 \mathrm{~cm}$.

FONSECA, A.M.; GONZAGA, V.C. Metodologia para auditoria de serviços de Limpeza urbana, com enfoque nos custos de Coleta de RSU. Belo Horizonte, 2006.

GÁS VERDE, Empresa gestora pela exploração comercial do aterro Jardim Gramacho, RJ. Informações técnicas obtidas junto ao diretor industrial. Eduardo Laganá, 2012. 
GARCIA, C. Brasil tem plano para diminuir emissão de gases poluentes. UNIVERSIDADE METODISTA DE SÃO PAULO. Disponível em: <www.metodista.br>. Acesso em: 12 nov. 2013.

GERESOL Programa de Administração e Gerenciamento de Resíduos Sólidos. Universidade Federal de Minas Gerais, 1999. Disponível em: < https://www.ufmg.br/proex/geresol/lixohistoria.htm>. Acesso em: 12 dez. 2013.

GODLOVE, C. Tecnologias para o aproveitamento energético do Biogás, Methane for Markets US Environmental Protection Agency (USEPA). Disponível em: <http://www.globalmethane.org/documents/events_land_20100917_4_goodlove.pdf.>.

Acesso em: 17 out. 2012.

GRANDELLE, R. A caminho da escassez. Jornal O GLOBO ciência pág. 26. Em 26 abr. 2012.

HAMILTON, S.L. Microturbine Generator Handbook. Penn Well Corporation, 2003. ICLEI - LACS, Manual para Aproveitamento de Biogás. 79 p.

HAGEN, M.; POLMAN, E.; MYKEN, A.; JENSEN, J.; JONSSON, O.; DAHL, A. Adding Gas from Biomass to the Gas Grid: Final Report. Contract No: XVII/4.1030/Z/99-412. European Commision. 2001, 142 p.

HENRIQUES, R.M.; OLIVEIRA, L.B.; COSTA, A.O. Geração de energia com RSU: Análise custo benefício. IVIG-COPPE/UFRJ. Disponível em: 〈http://www.ecoeco.org.br/conteudo/publicações/encontros/ven/Mesa4/10.pdf >. Acesso em: 25 mar. 2012.

ICLEI - Brasil - Governos Locais pela Sustentabilidade, Secretariado para América Latina e Caribe (LACS), Escritório de projetos no Brasil, São Paulo, Manual para aproveitamento do biogás: volume um, aterros sanitários. 2009. Disponível em: <www.resol.com.br/cartilha12/manual_iclei_brazil.pdf>. Acesso em: 12 abr. 2012.

INTERNATIONAL PANEL ON CLIMATE CHANGE (IPCC). Guidelines for National Greenhouse Inventories: Reference Manual (Vol.3), 1996. Disponível em: 〈http://www.ipcc-nggip.iges.or.jp/public/gl/invs6.> Acesso: 20 mar. 2012.

INTERNATIONAL PANEL ON CLIMATE CHANGE (IPCC). The Science of Climate Change - Summary for Policymakers, Office Graphics Studio, Madrid, 1995.

INTERNATIONAL PANEL ON CLIMATE CHANGE (IPCC). Guidelines for National Greenhouse Gas Inventories. (2006). Disponível em: <http://www.ipccnggip.iges.or.jp/public/2006gl/pdf/2 Volume2/V2 3 Ch3 Mobile Co mbustion.pdf $>$. Acesso em: 18 fev. 2012.

INTERNATIONAL PAINEL ON CLIMATE CHANGE (IPCC). Módulo 6 - Lixo, Guia para Inventários Nacionais de Gases de Efeito Estufa. Volume 2: Livro de Trabalho, 1996.

KIRILOS, P. A coleta seletiva da COMLURB. Disponível em: <http://oglobo.globo.com/rio/a-coleta-seletiva-da-comlurb-4340866>. Acesso em: $10 \mathrm{fev}$. 2013. 
LAFAETE- Locação e equipamentos. Disponível em: <http://www.lafaetelocacao.com.br/pt/equipamentos/caminhaopoliguindaste>. Acesso em: 25 jan. 2014.

LVOVSKY, K. et. al. (2000). Environmental Costs of Fossil Fuels. Paper $n^{\circ} 78$ da Pollution Management Series. Banco Mundial. Disponível em: <http://lnweb18.worldbank.org/SAR/sa.nsf/Countries/India/729C363672AE053E85256C 23007ACF62?OpenDocument>. Acesso em 25 nov. 2013.

LIMA, M.P. Custeio do Transporte Rodoviário. Disponível em: $<$ http://www.ogerente.com.br/log/dt/logdt-custeio_transporte_rodoviario.htm>. Acesso em: 12 out. 2014.

MAC KNIGHT, V. Análise custo benefício da substituição do diesel por gás natural veicular em ônibus na região metropolitana de São Paulo em 2004. Universidade Federal do Rio de Janeiro. Instituto de Economia, monografia, 2006.

MACHADO, G.B.; MELO, T.C. de.; LASTRES, L.F.M. Utilização de Gás Natural em Motores e Cenário do Uso no Brasil. - PETROBRAS/CENPES/PDAB/DPMLPE (2007). Disponível em: $<$ http://www.petrobras.com.br/minisite/premiotecnologia/pdf/TecnologiaGas_GasNatural _Motores.pdf $>$. Acesso em: 12 out. 2012.

MAGALHÃES, A. P. T. Biogás: um projeto de saneamento urbano. 1986.

MASCHKE, C. Preventive Medical Limits for Chronic Traffic Noise Exposure

Acústica, Germany, v.85, p. 448-461, 1999.

MATOS, A.R.V. Contribuição para o estudo da influência da "recirculação de lixiviados no comportamento de aterros de RSU". Faculdade de Ciências e Tecnologia da Universidade Nova de Lisboa Mestre em Engenharia do Ambiente, perfil em Engenharia Sanitária, 2008.

MENDES, A.P.F. Uma avaliação do impacto ambiental no Brasil: Poluição do ar e mortalidade. Dissertação de mestrado em Planejamento Energético. COPPE/UFRJ, 1993.

MEYER, C.R. Implicações Energético-Ambientais de Esquemas de Sucateamento de Automóveis no Brasil [Rio de Janeiro] 2001 XV, 109 p. 29,7 cm COPPE/UFRJ, Planejamento Energético, 2001.

MONTEIRO, J.H.P. [et al.]; Gestão integrada de resíduos sólidos, Manual de Gerenciamento Integrado de resíduos sólidos. Rio de Janeiro: IBAM, 2001.

MONTEIRO, C. Microturbinas. Produção e Transporte de Energia II. LEEC Faculdade de Engenharia da FEU, 2004. Disponível em: <http://paginas.fe.up.pt/ fmb/PTE2/Apontamentos\%20PTE2/PTE2_Microturbinas.pdf >. Acesso: em 25 nov. 2013.

NASA Road Transportation Emerges as Key Driver of Warming in New Analysis from NASA. Disponível em: <http://www.nasa.gov/topics/earth/features/roadtransportation.html $>$. Acesso em: 12 abr. 2012.

(1987). NBR 10004: Resíduos sólidos - classificação. ABNT - Associação Brasileira de Normas Técnicas. 
(1993). NBR 12808: Resíduos de serviços de saúde - classificação. ABNT - Associação Brasileira de Normas Técnicas.

(1993). NBR 12980: Coleta, varrição e acondicionamento de RSU - terminologia. ABNT - Associação Brasileira de Normas Técnicas.

NGV JOURNAL Natural gás vehicles. Disponível em: <http://www.ngvjournal.com/pt/fotos/veiculos〉 Acesso em: 18 out. 2013.

NGV JOURNAL Natural Gas Vehicles TFC Recycling adds five NGVs in Virginia. Disponível em: <http://www.ngvjournal.us/vehicles/item/7109-tfc-recycling-adds-fivengvs-in-virginia $>$. Acesso em: 18 out. 2013.

NISSAN DIESEL ENVIRONMENTAL IMPACT Product Life Cycle and the Environmental Impact.(2006). Disponível em:

$<$ http://www.docstoc.com/docs/23557318/Product-Life-Cycle-and-the-EnvironmentalImpact >. Acesso em: 12 dez. 2013.

OECD, IEA, 1996. Revised 1996 IPCC Guidelines for National Greenhouse Gas Inventories. Bracknell, Reino Unido.

OLIVEIRA, R.D. Geração de energia elétrica a partir do biogás produzido pela fermentação anaeróbia de dejetos em abatedouro e as possibilidades no mercado de carbono. Graduação em eng. Elétrica. Escola de Engenharia de São Carlos, São Paulo, 2009.

OLIVEIRA, J.A. Utilização de Cenários Normativos para formulação de Políticas Públicas: A adoção do gás natural veicular - GNV no sistema de transporte público por ônibus no município de Fortaleza, 368p.Tese de Doutorado em Engenharia dos Transportes. COPPE/UFRJ, 2005.

OPTIGEDE.ADEME Agence de l'Environnement et de la Maîtrise de l'Energie Partage d'expériences / Collecte des déchets en BOM hybrides diesel/électriques. Disponível em: $<$ http://optigede.ademe.fr/fiche/collecte-des-dechets-en-bom-hybrides-gnvelectriques $>$. Acesso em: 2 jun. 2014.

ONU - Organização das Nações Unidas ONU e a população mundial. Disponível em:

<http://nacoesunidas.org/acao/populacao-mundial/> . Acesso em: 12 jan. 2014.

PARCHEN, C. A. Manual de Biogás. Curitiba, EMATER-Paraná, 1979.

PECORA, V.F.N.J.V.; PIPGE, C.S.T.; VELÁZQUEZ, S.M.S.G. Potencial de geração de energia elétrica e iluminação a gás por meio do aproveitamento de biogás proveniente de aterro sanitário. IEE/CENBIO - Instituto de Eletrotécnica e Energia / Centro Nacional de Referência em Biomassa - Universidade de São Paulo (USP) Departamento de Engenharia Mecânica - Universidade Presbiteriana Mackenzie.

PECORA, V.N.J.V. de F.; SUANI, T.C.; SÍLVIA, M.S.G.V. Biogás e o mercado de crédito de carbono. CENBIO Centro Nacional de Referência em Biomassa, 2008.

PEGURIER, E. Toronto testa caminhão de lixo movido a lixo. Disponível em: $<$ http://www.ecocidades.com/2010/11/15/toronto-testa-caminhao-de-lixo-movido-alixo/>. Acesso em: 2 dez. 2012. 
PEGURIER, E; MORIYAMA, V. Apesar de fechado, Gramacho é uma história inacabada. Disponível em <http://www.oeco.org.br/reportagens/26063-apesar-defechado-gramacho-e-uma-historia-inacabada>. Acesso em 15 dez. 2013.

PEREIRA, A.G.H. VAN, E. Mecanismo de desenvolvimento limpo aplicado a resíduos sólidos. Ministério do Meio Ambiente, Ministério das Cidades, Redução de emissões na disposição final. Rio de Janeiro: IBAM, 2007.

PETROBRÁS DISTRIBUIDORA Óleo Diesel. (2010). Disponível em: $<$ http://www.br.com.br/wps/portal/portalconteudo/produtos/parafrotas/oleodiesel/!ut/p/c5 /1Y_BcoIwFEW_pR_AJCEIuCQiRFQiCMVkw1CNGRCIDBUsX1WddF2Om955tx7HxBgulvR16r4KJtbUYMDEGY-4iFax9B1sZLqIdb28OWgS>. Acesso em: 12 dez. 2011.

PETROBRÁS DISTRIBUIDORA GNV - Gás Natural Veicular. (2010). Disponível em $<$ http://www.br.com.br/wps/portal/portalconteudo/produtos/parafrotas/oleodiesel/!ut/p/c5 /1Y_BcoIwFEW_pR_AJCEIuCQiRFQiCMVkw1CNGRCIDBUsX1WddF2Om955tx7HxBgulvR16r4KJtbUYMDEGY-Z4iFax9B1sZLqIdb28>. Acesso em:

12 dez. 2011.

PÓLIS, PUBLICAÇÃO PÓLIS, No 31, 1998 Coleta Seletiva de Lixo Reciclando Materiais, Reciclando Valores. Disponível 〈http://www.polis.org.br/uploads/984/984.pdf $\rangle$. Acesso em: 22 set. 2013.

PORTOMARAVILHA Disponível em:

$<$ http://www.portomaravilha.com.br/conteudo/estudo/Projeto-de-Gerenciamento-deResiduos-da-Construcao-Civil-para-as-Obras-de-Infraestrutura-Setores-G-H-J-M-N.pdf, > Acesso em: 27 set. 2013.

PNUD Programa das Nações Unidas para o Desenvolvimento Relatório do Desenvolvimento Humano de 2011 Sustentabilidade e Equidade: Um Futuro Melhor para Todos. Disponível em: $<$ http://www.pnud.org.br/HDR/arquivos/RDHglobais/hdr_2011_pt_complete.pdf $>$.

Acesso em: 12 abr. 2012.

PNUMA Programa das Nações Unidas para o Meio Ambiente. UNEP The Emissions Gap Report 2012. United Nations Environment Programme (UNEP). Disponível em: $<$ http://ipea.gov.br/portal/images/stories/PDFs/121121 unep\%20emissions gap report.p df> Acesso em: 27 abr. 2013.

PRATI, L. Geração de energia elétrica a partir do biogás gerado por biodigestores. CURITIBA. Monografia apresentada Graduação de Engenharia Elétrica, Universidade Federal do Paraná, 2010.

PRICEWATERHOUSECOOPERS, Gestão da Limpeza Urbana Um investimento para 0 futuro das cidades. (2010). Disponível em: <http://www.selurb.com.br/upload/Guia PNRS 11 alterado.pdf >. Acesso em: 12 abr. 2012.

PRICEWATERHOUSECOOPERS, SELUR, ABLP Guia de orientação para adequação dos Municípios à Política Nacional de Resíduos Sólidos (PNRS). (2011). Disponível em: <http://www.selurb.com.br/upload/Guia_PNRS_11_alterado.pdf>. Acesso em: 12 abr. 2012. 
PVIPOWER VEHICLE INNOVATION (2012). Disponível em: <http://www.pvi.fr/?lang=fr >. Acesso em: 12 dez. 2013.

QUADROS, F.S. Avaliação do Ruído Ambiental gerado por Veículo de Utilidade Pública. Estudo de caso: caminhão de coleta de resíduos domiciliar. Dissertação apresentada como requisito à obtenção do grau de Mestre em Engenharia Mecânica, programa de Pós-Graduação em Engenharia Mecânica, setor de Tecnologia, Universidade Federal do Paraná, CURITIBA, 2004.

RIO GRANDE DO SUL (estado) Secretaria de infraestrutura e logística do RS. Sulgás integra projeto de caminhão de lixo movido a GNV. Rauber,F Liliana. Disponível em: <http://www.seinfra.rs.gov.br/conteudo/66091/?Sulg\%C3\%A1s_integra_projeto_de_cam inh\%C3\%A3o_de_lixo_movido_a_GNV>. Acesso em: 12 dez. 2013.

REAL, J.L.G. Riscos Ambientais em aterros de resíduos sólidos com ênfase na emissão de gases (Rio de Janeiro). COPPE/UFRJ M.sc. Engenharia Civil Tese Universidade Federal do Rio de Janeiro, 2005.

RESENDE, A.L. Revista Página 22 - Centro de Estudos em Sustentabilidade da EAESP Fundação Getúlio Vargas Disponível <http://pagina22.com.br/index.php/2012/04/entrevista-com-andre-lara-resende/>.

Acesso em: 10 jul. 2013.

RESOL, Cartilha de limpeza urbana. Disponível em: <http://www.resol.com.br/cartilha/apresentacao.php>. Acesso em: 15 jan. 2011.

REVISTA VEJA (2010). Sustentabilidade edição especial - Como o lixo vira riqueza. Págs. 23, 24, 25.

RIBEIRO, S.K. Transporte e meio ambiente. COPPE/UFRJ, 2005. Disponível em: <http://www.cbtu.gov.br〉>. Acesso em: 5 dez. 2012.

RIBEIRO, A. Dá para crescer sem sujar Revista Época. Disponível em: $<$ http://revistaepoca.globo.com/Revista/Epoca/0,EMI147163-15223,00-

DA+PARA+CRESCER+SEM+SUJAR.htm>. Acesso em: 5 dez. 2012.

SABETAI, C. Os Bilhões Perdidos no Lixo, Humanitas, São Paulo, 1997.

SANTOS, T. M. B. Balanço energético e adequação do uso de biodigestores em galpões de frangos de corte. 167 f. Tese (Doutorado em Produção Animal) - Fac. de Ciências Agrárias e Veterinária, Universidade Estadual Paulista, Jaboticabal, 2001.

SELURB/ABLP. Gestão da Limpeza Urbana. Um investimento para o futuro das cidades. São Paulo: Selur, ABLP, 2010. Disponível em: <http://www.selurb.com.br/upload/estudo_selur_2010.pdf〉. Acesso em: 3 dez. 2011.

SOUSA, B.C. da S. Determinação de rota ótima de um caminhão de coleta de resíduos para um bairro baseado no problema do carteiro chinês. UFF-Escola de Engenharia Industrial Metalúrgica de Volta Redonda.

TAKAHASHI, S. Avaliação ambiental do setor de transporte de cargas: comparação de métodos, 2008. Dissertação (mestrado em engenharia) Programa de pós-graduação em engenharia mecânica e de materiais, Universidade tecnológica do Paraná, Curitiba, 90p. 
TCHOBANOGLOUS, G.; THEISEN, H. \& VINIL, S Integrated solid waste management, Engineering principles and management issues, Irwin MacGraw-Hill, 1993, 978p.

TRIGUEIRO, A. O lixo que vira energia. Disponível em: <http://g1.globo.com/platb/mundo-sustentavel/2013/03/01/o-lixo-que-vira-energia>.

Acesso em: 3 dez. 2013.

TRIGUEIRO, $\quad$ A. $\quad$ A $\quad$ geração $\quad \mathbf{4 0 0}$ ppm. Disponível em <http://g1.globo.com/platb/mundo-sustentavel/2013/05/13/a-geracao-440-ppm/>. Acesso em: 12 nov. 2013.

USIMECA- disponível em:< http://www.usimeca.com.br/>. Acesso em: 12 dez. 2013.

UNITED STATES ENVIRONMENT PROTECTION AGENCY USEPA (1995). Decision-makers guide to solid waste management, volume II. Environmental Protection Agency, Office of solid waste division, Washington.

UNITED STATES ENVIRONMENT PROTECTION AGENCY USEPA LFG Energy Project Profiles. Disponível em: $<$ http://www.epa.gov/lmop/projectscandidates/profiles.html>. Acesso em: 25 jul. 2012.

UNITED STATES ENVIRONMENT PROTECTION AGENCY USEPA Landfill Methane Outreach Program. Disponível em: $<$ http://www.epa.gov/lmop/basicinfo/index.html>. Acesso em: 25 jul. 2012.

UNITED STATES ENVIRONMENT PROTECTION AGENCY USEPA Energy Projects and Candidate Landfills. Disponível em: <Energy Projects and Candidate landfills>. Acesso em: 25 jul. 2012.

UNITED STATES ENVIRONMENT PROTECTION AGENCY USEPA City of Los Angeles bureau of sanitation with LNG heavy-duty trucks. Disponível em:<environmentla.org/programs/altfuelvehicles.htm>. Acesso em: 25 jul. 2012.

VANZIN, E.J.W.; JIMÉNEZ, R.; PANDOLFO, A.; PANDOLFO, L.S.M.; MARTINS, M.S.; SAÙGO, A.; GHENO, R. Geração de Energia Através de Biogás: Estudo de Viabilidade Econômica. Porto Alegre: Editora SGE, 2009.

VEJA - Coleta seletiva é exceção nos municípios brasileiros. - Disponível em: <http://veja.abril.com.br/tag/reciclagem>. Acesso em: 12 mar. 2012.

VEOLIA What improves waste management? Galileo 3,2011, Disponível em: $<$ http://www.veoliaenvironmentalservices.com/veolia/ressources/files/1/918,GALILEO3 USEPA-1.pdf $>$. Acesso em: 25 nov. 2012.

VESTIBULANDO WEB Biocombustíveis (Biodiesel): vantagens e desvantagens. Disponível em: <http://www.vestibulandoweb.com.br/biologia/teoria/biocombustiveis.asp >. Acesso em: 10 jul. 2012.

VIEIRA, S.M.M; SILVA, J.W. Emissões de metano no tratamento e na disposição de resíduos. 
XAVIER, Reinaldo de Souza Modelagem e minimização do consumo de combustível para rotas de coleta de lixo. UFMG. Proposta de dissertação apresentada ao Programa de Pós-Graduação em Engenharia Elétrica da Escola de Engenharia da Universidade Federal de Minas Gerais, 2010.

WILLUMSEN, H.C. Energy Recovery from Landfill Gas in Denmark and Worldwide. LG Consultant, 2001.

WOLMER, A.F. Apostila de Limpeza Urbana. Disponível em: <http://www.ebah.com.br/content/ /apostila-limpeza-urbana>. Acesso em: 12 jun. 2012.

ZANNIN P.H.T., CALIXTO A., DINIZ F. B. D., FERREIRA J. A. C., SCHULLER R. Incômodo Causado pelo Ruído Urbano à População de Curitiba, PR. Revista de Saúde Pública, São Paulo, v.36, n. 4, p. 521-524, 2002.

ZIEGLER, M.F. Queimar lixo não é a melhor solução. Disponível em: <http://ultimosegundo.ig.com.br/ciencia/meioambiente/queimar-lixo-nao-e-amelhor-solucao-afirmam-especialistas/n1597737615770.html >. Acesso em: 11 mai. 2012 